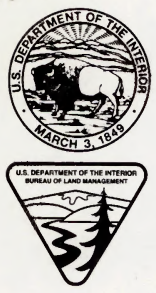

U.S. Department of the Interior

Bureau of Land Management

Rawlins District Office

Great Divide Resource Area

June 1995

\title{
FINAL \\ Laramie Peak Big Horn Sheep Habitat Management Plan
}

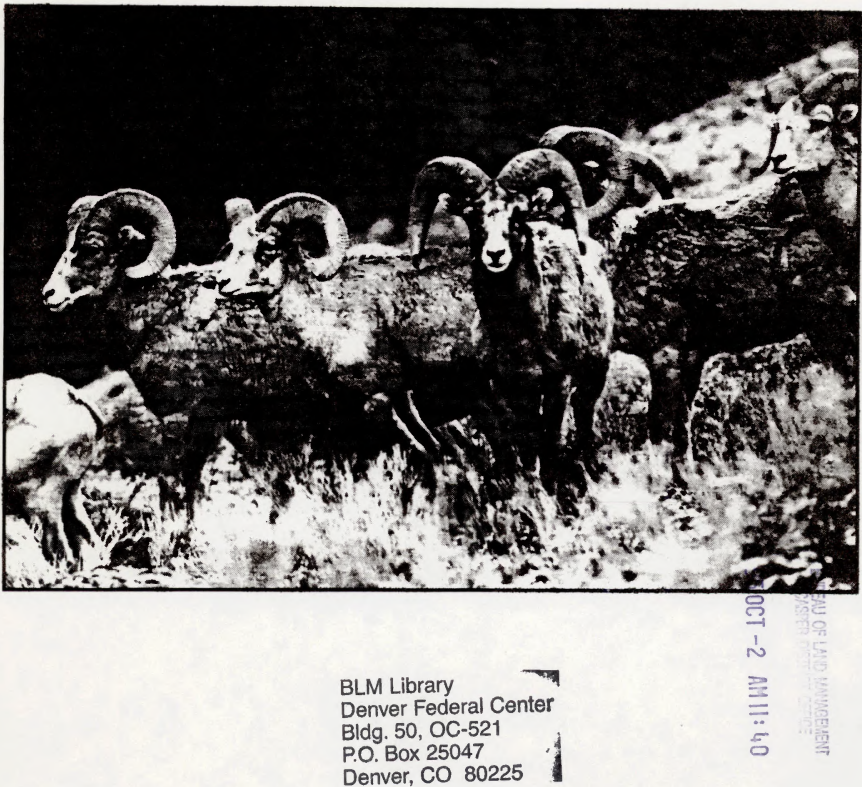



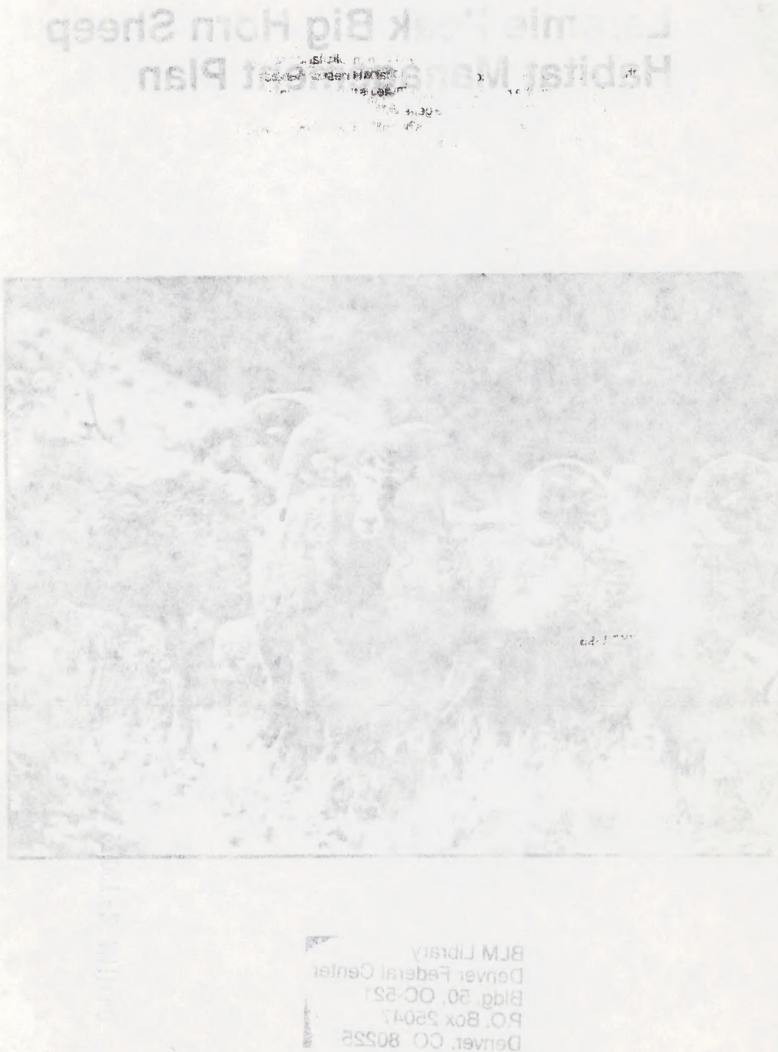
The Bureau of Land Management is responsible for the balanced management of the public lands and resources and their various values so that they are considered in a combination that will best serve the needs of the American people. Management is based upon the principles of multiple use and sustained yield; a combination of uses that take into account the long term needs of future generations for renewable and nonrenewable resources. These resources include recreation, range, timber, minerals, watershed, fish and wildife, wilderness and natural, scenic, scientific and cultural values. 

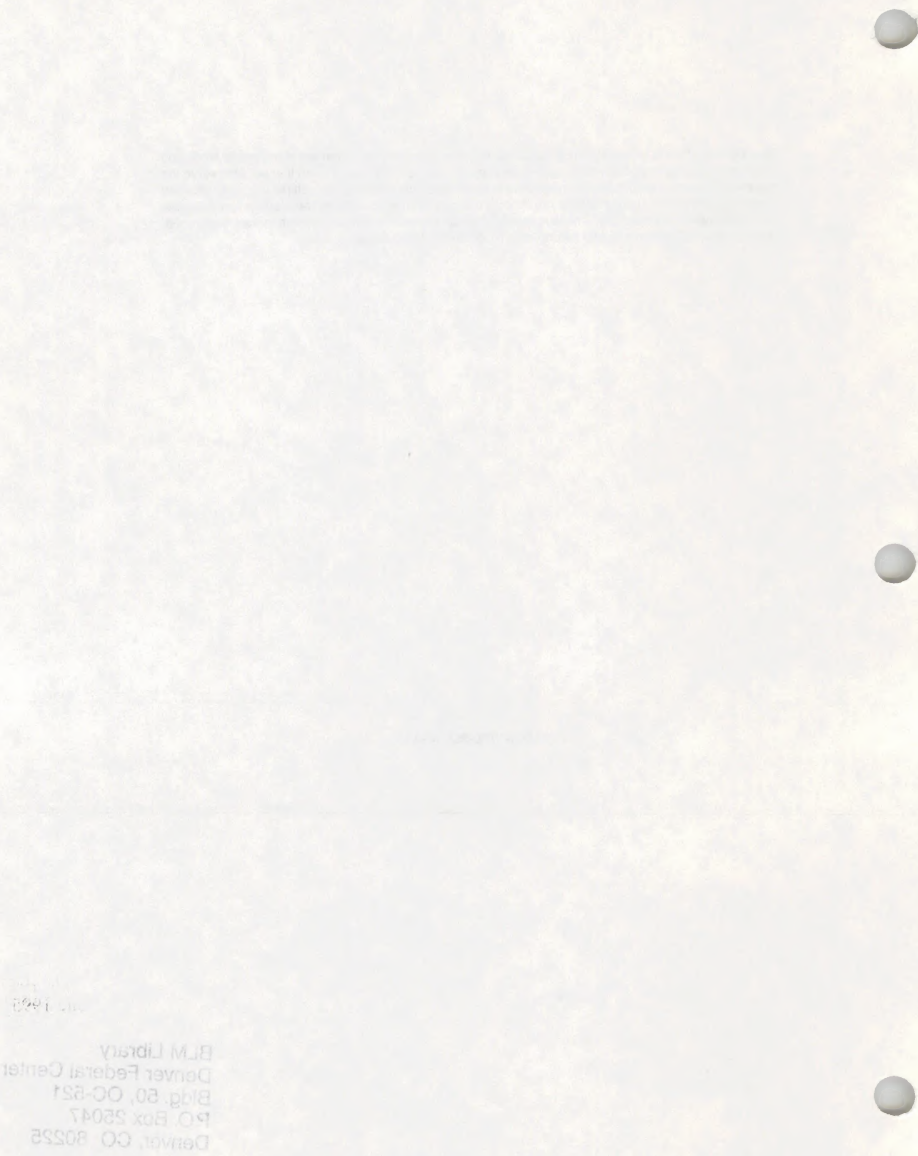


\title{
LARAMIE PEAK BIGHORN SHEEP HABITAT MANAGEMENT PLAN
}

\author{
Great Divide Resource Area \\ Rawlins District
}




\section{USE OF \\ ADMINISTRATIVE DETERMINATION FORM}

Purpose of the Administrative Determination (AD) Process. Is to assure that a qualified proposed action meets the requirements of NEPA, while reducing documentation. The AD process streamlines the NEPA evaluation and documentation procedures by relying upon existing, satisfactory documents to provide an efficient, but recoverable product. The $A D$ process involves using existing EAs and EISs for new proposed actions in those situations where existing documents sutficiently address a new proposal and its potential impacts. This includes cumulative Impactsl

\section{PART I IDENTIFY:}

In order for a manager to make this determination, the first step is to fully describe the proposal/project.

\section{PART II PLAN CONFORMANCE:}

The next step is to determine whether or not the action/proposal/etc. is in conformance with the LUP.

\section{PART III NEPA REVIEW/DETERMINATION:}

The next step in the $A D$ process involves:

1. DETERMINING, what if, any, relevant analyses related to the proposed action have been prepared, whether or not the analyses are adequate, who prepared or cooperated in the preparation of the analyses, and if any of the analyses fully cover the new proposed action. Documents that may be relevant include, but are not limited to MFPs/RMPs, or the following: - EISs associated with BLM resource management plans; - EISs or EAs associated with BLM plan amendments; - EISs or EAs on BLM programmatic actions; - ElSe or EAs associated with BLM activity or project plans; - EISs or EAs prepared by other agencies, particularly those on which BLM was formally a cooperating agency. (Where BLM was not a cooperating agency, an adoption process must be followed.)

2. CONDUCTING THE ANALYSIS: Existing relevant EAs and EISs are reviewed against (at a minimum) the seven criteria (NEPA Handbook, pp. III-1 and III-2): found in PART II of this form.

3. CONFIRMATION:

- If all seven criteria are met, proceed with $A D$ documentation.

- If one or more of the seven criteria are not met, the AD documentation process is not appropriate. You must proceed with further screening to determine the appropriate documentation process to follow.

\section{PART IV DOCUMENTATION/DECISION:}

Two elements of documentation are involved:

1. Documenting the determination that the $A D$ process is appropriate, and

2. Documenting the decision on the proposed action. 


\section{Table of contents}

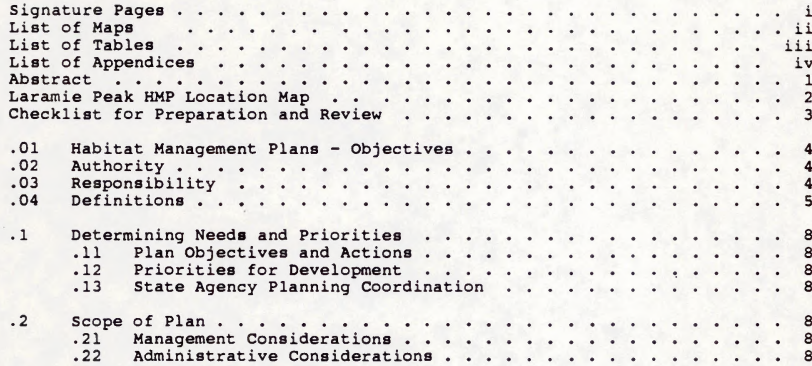

.3 The Laramie Peak hMp Plan .. . . . . . . . . . . . . . . . . 10

.31 Introduction . . . . . . . . . . . . . . . . . . . . . 10

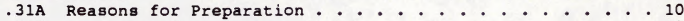

.31B Ecosystem Description . . . . . . . . . . . . . . . 13

.31B.1 Bighorn Sheep Population Dynamics. . . . . . . 13

.31B.1.a Bighorn Sheep Sub-Herd Locations

within the HMP Area... .. . . 16

.31B.1.b Bighorn Sheep Habitat Types . . . . 16

.31B.1.C Historical Activities Affecting

Current Bighorn Sheep Populations . 18

.31B.1.d Population Objective/Modeling

for Bighorn Sheep Herds... . . . 18

.31B.1.e Harvest/Hunter statistics

for Bighorn sheep . . . . . . 19

.31B. 2 Other Fish and Wildlife Species/seasonal

occurrence by Habitat Types... . . . . . 20

.31B.2.a Big Game Habitat Types... . . . . . 20

.31B.2.b Upland Game Bird Habitat Types . . . . 21

.31B.2.C Raptor Habitat Types........ . . 22

31B.2.d Waterfowl, Shorebirds, Neotropical

Migratory Bird Habitat Types *. . 22

.31B.2.e Predator and Trophy Game Habitat Types........ 23

.31B.2.f Riparian Areas - Fisheries, Reptiles, Amphibians Habitat Types ... . 23

.31C Relevant Constraints . . . . . . . . . . . . . . . . . 23

.31D Sikes Act Authority . . . . . . . . . . . . . . . 25

.31D.1 objectives of the Act . . . . . . . . . . . . 25

.31D.2 Interagency Coordination............ 26

.32 Land Statug/Administration . . . . . . . . . . . . . . . . . 28

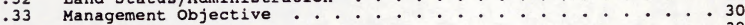

.34 Planned Actions... . . . . . . . . . . . . . . . . . 38

34A Description of Actions . . . . . . . . . . . . . . . 38

.34A.1 Existing and Planned Improvements to Summarize Actions............. . . 38

$.34 \mathrm{~A} .2$ Methods and Planned Actions Required to Achieve the HMP Objective.......... 39

.34A.3 Feasible Alternatives/Optional Methods . . . . . 54

$.34 \mathrm{~A} .4$ Title and File Location of Allotment 


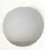

0

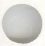


Management Plans in HMP Area . . . . . . 54

.34 A.5 Visitor Management in the HMP Area . . . . . . . 55

.34A.5.a Emergency Services . . . . . . . . 55

.34A.5.b Information and Interpretation

Services.......... . 55

.34A.5.C Visitor and Resource Protection . . 55

.34A.6 Planned Actions HMP Progress Report . . . . . . 61

.34B Information Sources to Support Actions . . . . . . . . . . 61

.34C Water Right Considerations................ . . . 62

Evaluation and Monitoring

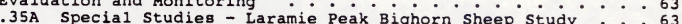

Habitat Management Plan Progresg Report

.37 Coordination With Other BLM Programs, Agencies,

and Organizations . . . . . . . . . . . . . . . . . 73

.37A Silviculture Procedures

.37B Livestock Grazing Management Applicable to the Wildife Program . . . . . . . . . . 76

.37C Recreation Activitieg Relative to the Wildlife Program ................. . 81

.37D Wilderness Designation Relative to the Wildlife Program .. . . . . . . . . . . . . 81

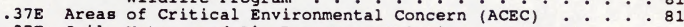

. 37F Soil, Water, and Air Resources Relative to the Wildlife Program .............. 83

$.37 \mathrm{G}$ Wild Horse and Burro Resources in the HMP Area . . . .84

. 37H Energy and Minerals Development Activities in the HMP Area ............... . 84

. 37 I Fire Management Program Relative to Habitat objectives: 84

$.37 \mathrm{~J}$ Archaeology/Paleontology Activities Relative

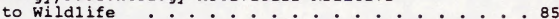

.37K Support Activities Relative to Implementing the HMP.${ }^{*} .86$

$.37 \mathrm{~L}$ Other Areas of Coordination Required to

38 Wildife Implement the HMP . . . . . . . . . . . . . . 86

Economics . . . . . . . . . . . . . . . . . . . 87

.38A Methods . . . . . . . . . . . . . . . . . . . . 87

.38B Sources of Information . . . . . . . . . . . . . 88

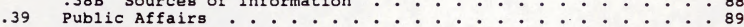

.39A Program Content . . . . . . . . . . . . . . . . . . 89

.39B Distribution . . . . . . . . . . . . . . . . 89

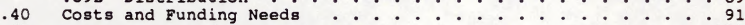

.41 Concurrence and Approval .. . . . . . . . . . . . . . . . 108

$41 \mathrm{~A}$ BLM - . . . . . . . . . . . . . . . . . . . . . . 108

$.41 \mathrm{~B}$ State Agencies and Others . . . . . . ... . . 108

References

- 110

Appendix I . . . . . . . . . . . . . . . . . . . . . . . . . . 111

Appendix II . . . . . . . . . . . . . . . . . . . . . . . . . . . 112

Appendix III . . . . . . . . . . . . . . . . . . . . . . . . . . 113

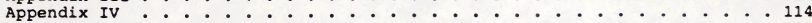

Appendix V . . . . . . . . . . . . . . . . . . . . . . . . . . . 115

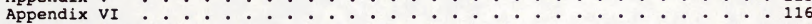

Appendix VII . . . . . . . . . . . . . . . . . . . . . . . . . 117

Appendix VIII . . . . . . . . . . . . . . . . . . . . . . . . . 118

Appendix IX . . . . . . . . . . . . . . . . . . . . . . . . . . . 119

Appendix $\mathrm{x}$. . . . . . . . . . . . . . . . . . . . . . . . . . . . 120

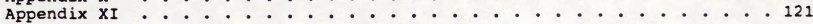




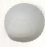

0

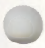




\title{
Laramie Peak Bighorn Sheep \\ Habitat Management Plan
}

Bureau of Land Management

U.S. Forest Service

Wyoming Game and Fish Department

\author{
Prepared By \\ Mary $J$. Read \\ wildife Biologist \\ Great Divide Resource Area \\ Rawlins District, BLM
}

HAP No. $T-34$
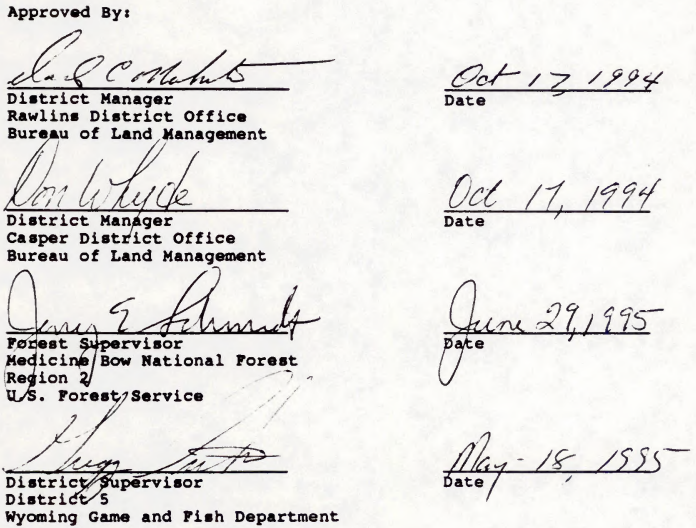


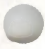

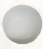

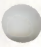




\section{List of Maps}

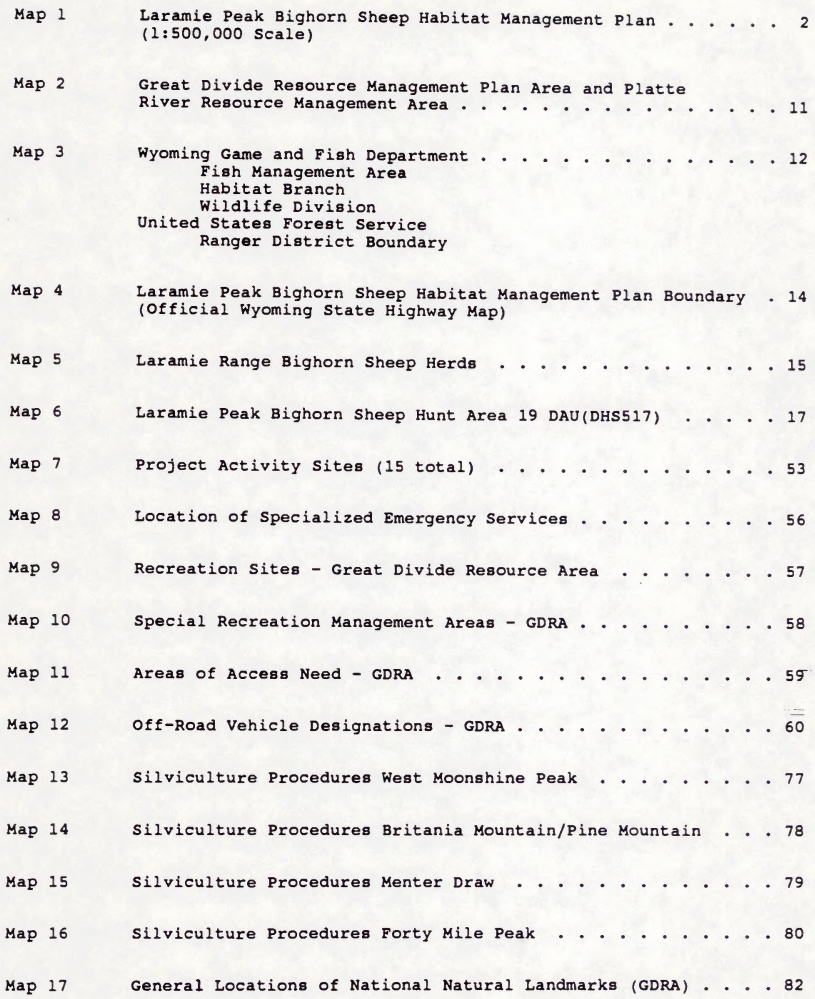


0

0

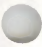




\section{List of Tables}

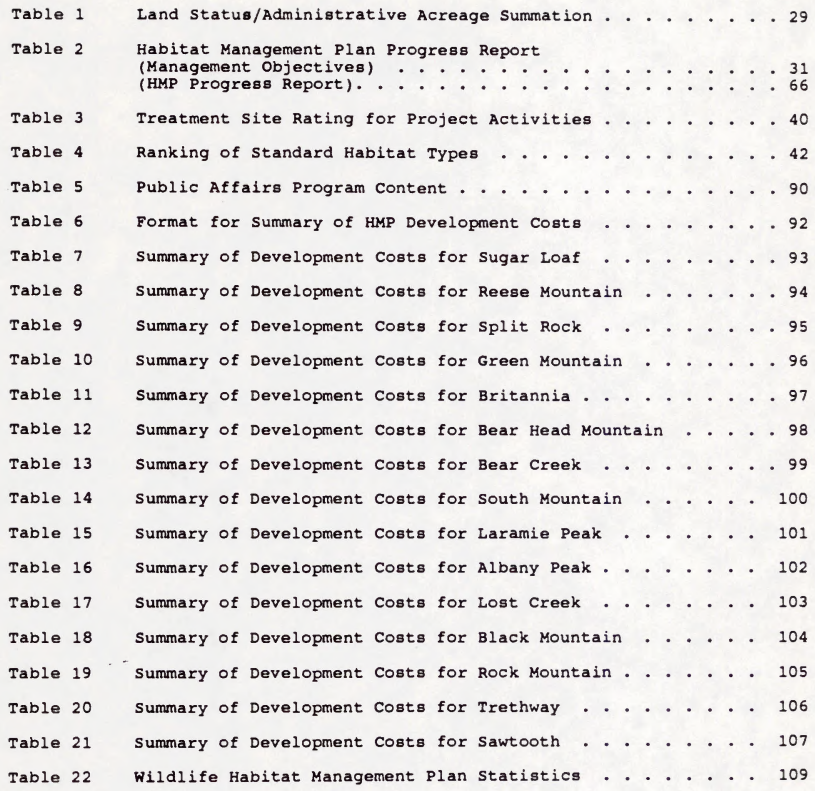


0

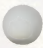

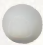


APPENDIX I Public Comments, Letters, Discussions Relevant to the Laramie Peak HMP ......................... 111

APPENDIX II Vegetation/Habitat Types . . . . . . . . . . . . 112 Major Range Sites Precipitation Zone Associated Wildlife Habitat Type

APPENDIX III Laramie Peak HMP Species Ligt . . . . . . . . . . . . 113 Common specieg Threatened/Endangered Species Species of Special Concern

APPENDIX IV Crucial Winter Range for Big Game Wildlife Specieg and WGFD Hunt Areas . . . . . . . . . . . . 114

APPENDIX V Breeding/Nesting Habitat for Sage Grouse - Crucial Winter Habitat for Turkeys............ 115

APPENDIX VI WGFD Hunt Areas - Major Predatorg . . . . . . . . . 116

APPENDIX VII General Framework of Guidance for the Bureau's (BLM) Fish and Wildlife Program .......... . 117

APPENDIX VIII BLM Standard Mitigation Guidelines for surface-Disturbing Activities................... . . . 118

APPENDIX IX Legislative and Executive Direction for the Bureau's Wildlife Program . . . . . . . . 119 Authority to implement HMPs

APPENDIX $x$ Split Rock Prescribed Burn: BLM Environmental Assessment WY-037-EAO-038.................. 120

APPENDIX XI Land Use Constraint's Relative to the WGFD's "Strategic Plan for the Comprehensive Management of Wildlife in Wyoming $(1984-1989)^{\prime \prime . . . . . . . ~} 121$ 


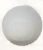

0

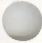




\begin{abstract}
The Laramie Peak Habitat Management Plan (HMP) is a comprehensive Bureau of Iand Management (BLM) activity plan prepared and implemented under authority of $\mathrm{Ti}$ - $e$ II, Public Law 93-452, otherwise referred to as the Sikes Act. This document a cooperative effort among the BLM, the Wyoming Game and Fish Department (WGFD), and the U.S. Forest Service (USFS) to manage bighorn sheep habitat on public lands in and adjacent to the Douglas Ranger District of the Medicine Bow National Forest. Although this is a cooperative effort, it has been prepared by a BLM Wildife Biologist and follows the BLM Manual 6780, Habitat Management Plan, therefore, it incorporates and tiers from many Bureau policies and land use plans that address wildlife issues and concerns. This HMP area is relatively large in geographical scope and is located throughout the Laramie Range north of Wyoming State Highway 34 , east of Wyoming Highway 487 and south to south-west of Interstate Highway 25 (R. 68-78W., T. 19-33 N.). This is the entire WGFD Hunt Area 19, which yields to less difficult management both economically and politically. The primary goal of the HMP is to improve the distribution of bighorn sheep populations and associated genetic diversity by increasing and improving the amount and quality of open, secure foraging areas (adjacent to water and escape cover) in site-specific habitat areas. The primary objective is to increase the bighorn sheep population from 173 animals to 500 animals by manipulating approximately 9,000 total acres of habitat by the year 2009-2010. There are fifteen (15) proposed habitat sites that will use the following planned actions, collectively or in a combination of, to implement the objectives of the HMP: prescribed burns, small commercial logging practices, assorted fence modifications, diverse riparian improvements that include in-stream structures, fencing, plantings, and reservoir developments. Site-specific Environmental Assessments (EAs) will be completed for each proposed site throughout the 10-15 year time span of the HMP, therefore, specific planned actions will be determined at that time.
\end{abstract}


0

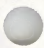

. 


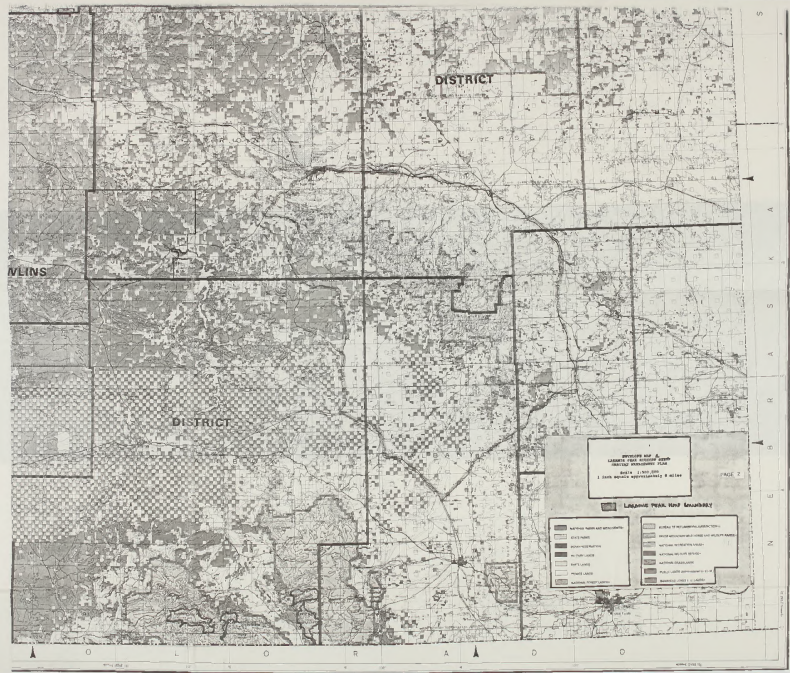




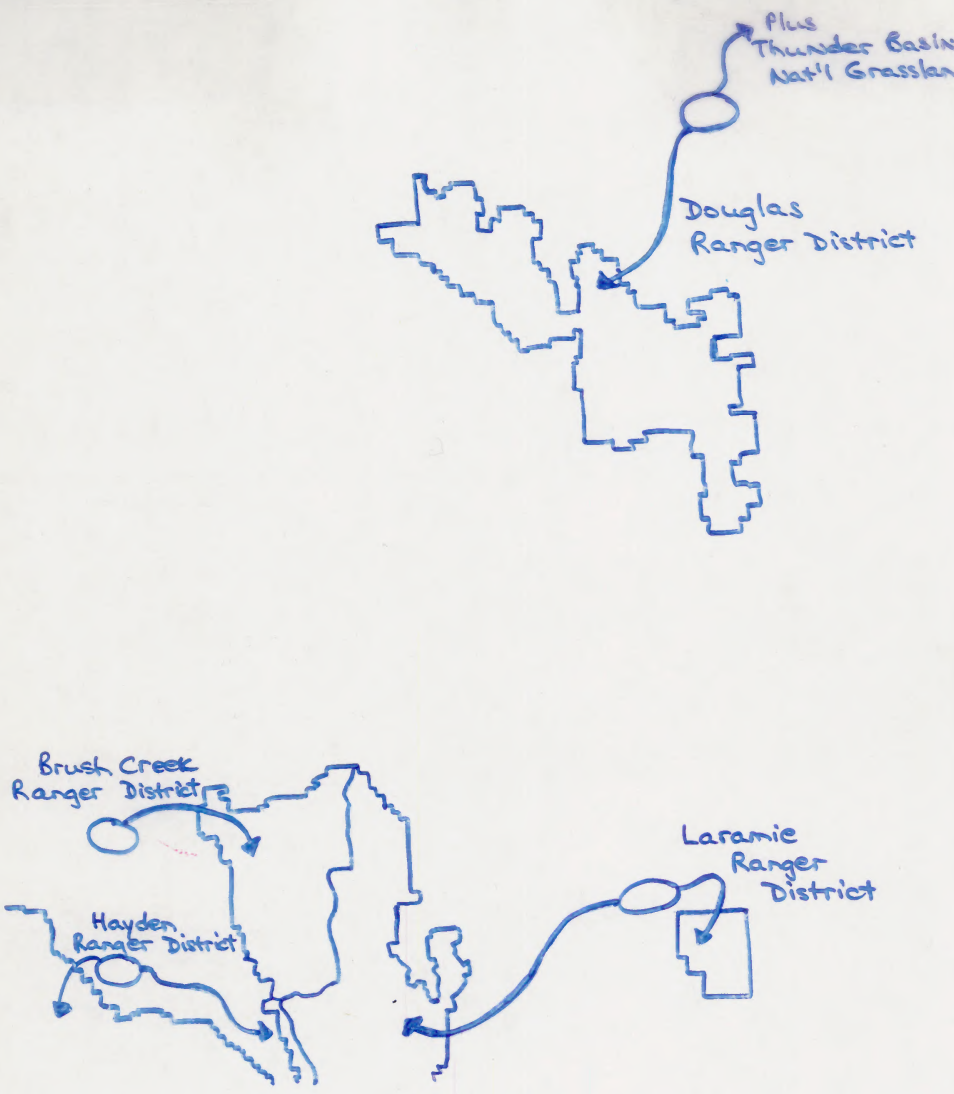

U.S. Forest Service

Ranger District Boundaries Laramie Ranger District Hayden Ranger District Douglas Ranger District Brush Creek Ramon Misprint 

Habitat Branch

Region 1

Habitat Branch

Region 3

Wyoming Game and Fish

Habitat Branch

Region 1
Region 

Fish management Area 55

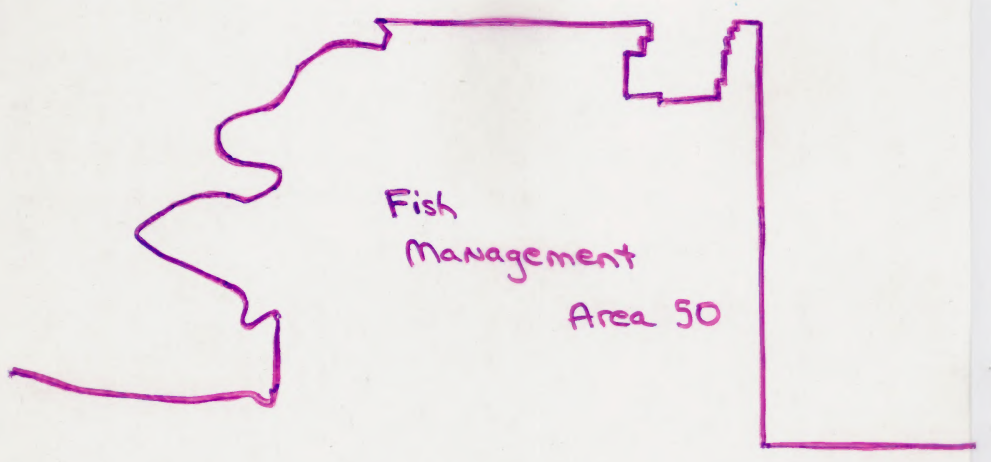

wyoming Game ard Fish Fish management Area Area 55 Area 50 


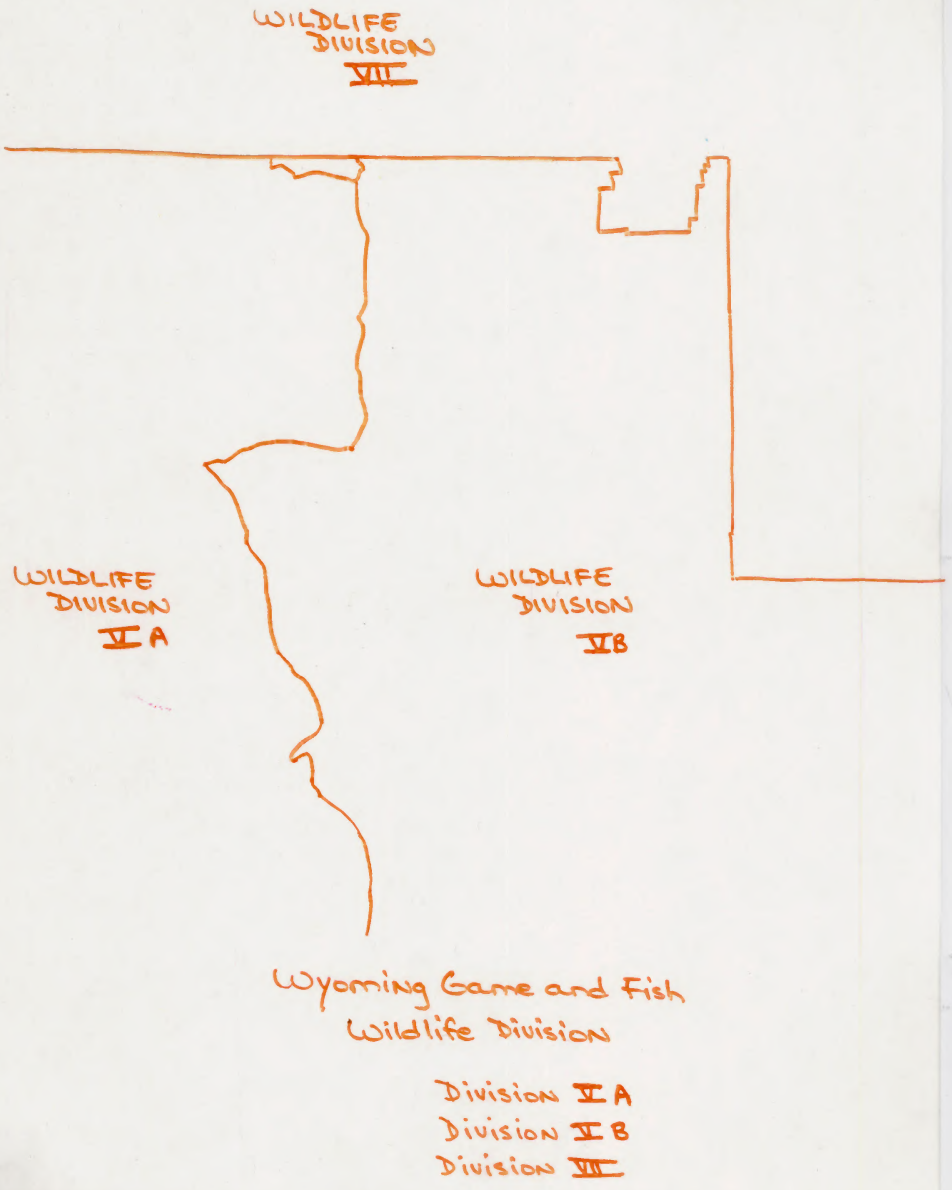

Form 6780-1

(July 1981)

(formerly $6620-1$ )
UNITED STATES

DEPARTMENT OF THE INTERIOR BUREAU OF LAND MANAGEMENT

CHECKLIST FOR PREPARATION AND REVIEW OF HABITAT MANAGEMENT PLANS

State

District wyoming Rawlins

Resource Area

Great Divide Resouree Area. HMP Name and Number Laramie Peak HMP - T-34

HMP Prepared by Mary J. Read

REVIEW CHECKLIST

1. Master Memorandum of Understanding, Sikes Act Agreement and/or Supplemental with State Agency.

Preliminary meeting(s) with State Agencv (or other appropriate cooperators) to jointly discuss HMP objectives.

3. Endangered Species Act Compliance completed by

4. Review by District/Resource Area Specialists

Range

Wild Horse and Burro

Hydrologist

Forestry

Fisheries/Botanist/Wildlife Biologist

Lands

Minerals

Recreation

Wilderness ACEC

Cultural

Visua!

Environmental Coordinator (revtews $E$ is)

Support (Cbiel of Operations/Fite Management)

Others

3. Reviewed by Area Manager

Reviewed by Chief of Resource Management

- Draft HMP and EA reviewed by State Agency authorized officer or other cooperators).

5. Final review ( 21 appropriate) by State Director

$\because$ Reviewed and approved by District Manager

i0. Approved by State Agency authorized officer

\begin{tabular}{|c|c|} 
Mary J.Read \\
SURNAME & DATE \\
\hline
\end{tabular}

\begin{tabular}{|l|l}
\hline man \\
\hline macy 1 . Read & Oct. 4, 1994 \\
\hline
\end{tabular}
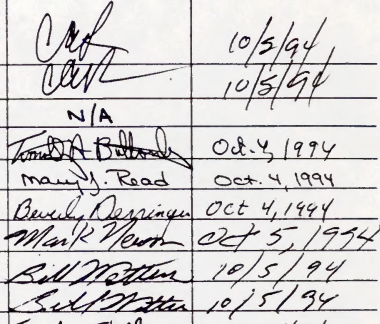

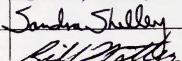

$10 / 5 / 94$
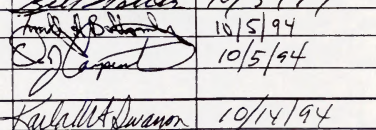

Walt seoge 10.18 .94

Remarks 
0

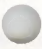

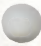


Form 6780-1

(July 1981)

UNITED STATES
1) DEPARTMENT OF THE INTERIOR
BUREAU OF LAND MANAGEMENT
CHECKLIST FOR PREPARATION AND REVIEW
OF HABITAT MANAGEMENT PLANS

(formerly $6620-1$ )

State

\begin{tabular}{|ll} 
& Wyoming \\
\hline District & \\
& Casper
\end{tabular}

Resource Area

HMP Name and Number

Laramie Peak HMP T-34

HMP Prepared by

Mary J. Read

REVIEW CHECKLIST

1. Master Memorandum of Understanding, Sikes Act Agreement and/or Supplemental with State Agency.

Preliminary meeting(s) with State Agency for other appropriate 2. cooperators) to jointly discuss HMP objectives.

3. Endangered Species Act Compliance completed by

4. Review by District/Resource Area Specialists

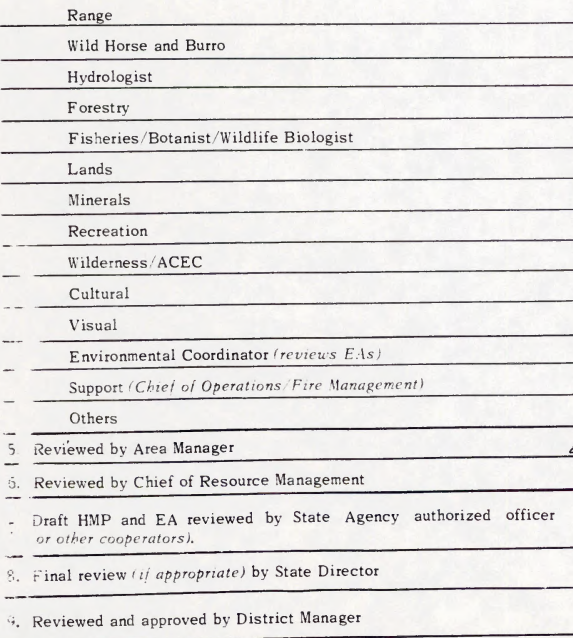

iv. Approved by State Agency authorized officer

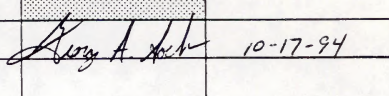

Pekuta quloar 10-17-94
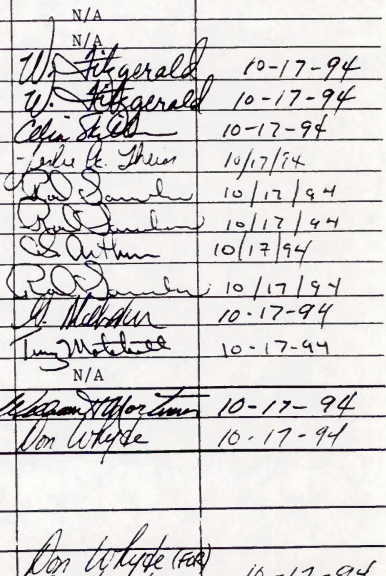
$10-17-94$ 
0

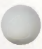

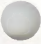




\section{HABITAT MANAGEMENT PLANS}

.01 objectives. The overall objective of any Habitat Management Plan (HMP) implementation is to manage habitats on the public lands for the conservation and rehabilitation of fish, wildlife, and plant resources consistent with multiple-use management principles. To meet this objective it is necessary to:

A. Provide procedures for preparation and implementation of HMPs with defined management actions or prescriptions to protect, improve, and maintain wildlife habitat.

B. Define specific BLY wildlife activity planning and on-the-ground project implementation procedures.

C. Provide continuity in developing HMPs and correlate wildlife population goals and objectives proposed by State wildlife agencies with BLM wildlife habitat management goals and objectives.

D. Ensure that HMPs meet the requirements of comprehengive plans as presented by Title II, Sec. 201(a) of the Sikes Act, as amended (P:L. 93-452; 16 U.S.C. et. seq.).

E. Promote the development and implementation of HMPs for the conservation of sensitive, threatened, and endangered plants and animals officially listed by Federal or State agencies.

.02 Authority. (See Appendix IX)

.03 Responsibility.

A. The Director and Associate Director are responsible for overall HMP program coordination and its interactions with all other Bureau programs. They are also responsible for determining Bureauwide priorities for HMP funding and implementation. These responsibilities are exercised through the Deputy Directors.

B. Deputy Director for Lands and Renewable Resources, within his/her assigned areas of responsibility, is responsible for the overall coordination and integration of HMP policies and procedures. He/she provides policy and program interpretations, direction, leadership, and line management to assure consistency of field implementation for HMPs.

C. Assistant Director Renewable Resources, is responsible for HMP policies, procedures, and programs that are consistent and coordinated with similar action plans for Rangeland Management, Wild Horses and Burros, Water Resources, and Forest Management. He/she identifies, addresses, and reconciles HMP issues and conflicts within and between programs under his/her responsibility.

D. Chief, office of Budget, is responsible for ensuring that requests for new authorization or appropriations transmitted to the office of Management and Budget (OMB) and the Congress are supportive of the Director's and Administration's funding and employment decisions for the preparation, implementation, and monitoring of HMPs.

E. Chief, Division of Administrative Services, is responsible for ensuring that procurement and assistance procedures used to implement HMps are in legal compliance with the Federal Land Policy and Management Act (FLPMA), Sikes Act, Public Rangelands Improvement Act, Federal Grant and Cooperative Agreement Act, Economy Act, OMB procedures, and Interior Department and BLM procurement regulations.

F. Chief, Division of wildlife, is responsible for developing and issuing guidelines for the preparation and implementation of HMPs and ensuring that they 


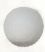

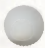

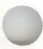


are consistent with principles of ecosystem management and coordinated with other resource activity plans. The Chief also is responsible for compiling Bureauwide HMP statistics, providing such information as is deemed necessary to support relevant budget requests, and being responsive to public Inquiries.

G. Chief, Division of Rangeland Resources, is responsible for ensuring that policies and guidelines for the preparation and implementation of livestock grazing Allotment Management Plans (AMPs) are coordinated with HMPs and consistent with principles of ecosystem management.

H. Chief, office of Planning and Environmental coordination, is responsible for the coordination of HMP-related guidelines and procedures with the Bureau's planning, inventory, and NEPA compliance systems through the Chief, Division of Wildlife, and that such gystems are consistent with the principles of ecosystem management.

I. Other Division and office Chiefs are responsible for ensuring that policies and guidelines for their respective resources' activity plans are coordinated with HMPs (e.g., Forest Management Plans, Mining Plans, wilderness Management Plans) and are consistent with principles of ecosystem management.

J. State Directors are responsible for quality control of HMPs, for establishing priorities for HMP preparation, implementation, and funding within their respective states, and for submitting the annual HMP statistics Report (Form 6780-3) to the Director (240) in a complete and timely manner. State Directors also are responsible for ensuring that HMPs are implemented and coordinated with their respective state agencies. A State Director has the option to approve and/or sign HMPs in coordination with the state agency Director.

K. District Managers sign and approve HMPs upon completion and ensure that requirements for Resource Management Plan (RMP) or Management Framework Plan (MFP) objectives and decisions are met. They also ensure that HMp statistics are submitted to the state Directors.

L. Area Managers are responsible for HMP preparation and on-the-ground habitat management and implementation of HMP and for ensuring that such plans meet the specified objectives, planned actions, and evaluations so prescribed in planning documents. They also recommend approval of HMPs, provide the required line management supervision for their preparation, revise/update HMPs as needed, and conduct coordination with local state agency personnel.

M. District and Resource Area Staff Wildlife and Fisheries Biologists and Botanists assist Area Managers in the preparation and coordination of HMPs with appropriate local state agency personnel. Staff biologists and botanists should ensure that the biological components of the plans are adequate, that they fulfill ecosystem management requirements, and that fish, wildife, and threatened or endangered plant and animal management priorities are established and scheduled in the HMP.

\section{.04 Definitions.}

A. Crucial Habitat: Habitat which is absolutely basic to maintaining viable populations of fish, wildlife, or plants during certain seasons of the year or specific reproduction periods.

B. Ecosystem Management: The integration of different land management goals to ensure that the integrity of the ecosystem will be maintained. Ecosystem management is directed toward habitat management rather than species management, the concept being that species will be maintained naturally if a proper mosaic of habitats exists. Ecosystem management encompasses featured species and species diversity to ensure compliance with existing laws; prevent species from becoming threatened or endangered; and provide values and uses for the public. The overall goal of ecosystem management for wildife is retention 


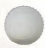

0

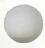


or management of all natural habitats in sufficient quantities to support viable and self-sustaining populations of all native wildlife; e.g., riparian areas, cliffs, wetlands, and old-growth forests.

C. Habitat Development: All actions to improve; protect; and maintain fish, wildife, and threatened, endangered, and sensitive plants and animals and their habitats. This includes funds, equipment, and personnel for: project survey and design; contract preparation; on-the-ground project work; project supervision; maintenance; on-site, pre- and post-project treatment studies and monitoring; and those public affairs programs necessary to explain habitat development and to denote HMP locations and purposes.

D. Habitat Management Plan: A written and approved activity plan for a geographical area of public lands which identifies wildlife habitat management actions to be implemented in achieving specific objectives related to RMP/MFP planning document decisions. Different terminology used for HMPs is as follows:

1. Sikes Act HMPg are prepared and implemented jointly with state agencies under authority of the Sikes Act, Title II and are thus the same as comprehensive plans. Such plans are denoted as Sikes Act HMPs in writing within the HMP itself and through the BLM-state agency Master Memorandum of Understanding or Supplements thereto.

2. Other HMPs are those not covered under the Sikes Act, which were either prepared prior to the Act's passage in 1974 or for some reason have not been designated as such.

3. Implemented HMP are those which have been approved for funding support and policy direction by the state Director and/or District Manager. In essence, they become implemented once funds and/or manpower have been obligated to accomplish habitat management actions on the ground. Funds so obligated can include state agency contributions as well as those of BLM and other Federal agencies.

4. Completed HMPg are those for which at least 90 percent of the total funds required for implementation have been obligated toward originally planned habitat improvement and protection actions and they are essentially in a maintenance phase.

5. New HMPs are those which have just been, or are being, prepared and can be ready for on-the-ground implementation and funding support during upcoming fiscal years (FYs); e.g., those classified as "new" at the end of FY 1982 can be implemented beginning with FY 1983.

6. Revised HMPs are those which have undergone updating and complete or partial revision to bring them within acceptable legal and policy standards.

E. Priority Species and Habitats: Those fish, wildlife, and plant species or habitats that have been identified in the MFP, RMP, or through special studies as having special significance for management. These may include endangered, threatened, or sensitive species, species of high economic or recreational value, and aquatic or riparian habitats. Also included are individuals or populations of animals and/or plants that are recognized as significant for one or more factors, such as density, diversity, size, disjunct occurrences, or age (e.g., the 11-12,000-year-old creosote bush rings in the California Desert Conservation Ares; the high diversity and density of nesting raptors in the Snake River Birds of Prey Area; or an area such as Ash Meadows in Nevada which supports a high concentration of rare plants and animals).

F. Reasonable Numbers: Population numbers of a species which are estimated to currently exist in a specific geographical area or are projected at a certain population level based on a long-term average. Reasonable population numbers are usually determined to assess allocation of forage for big game species. These numbers are derived from state agencies' input and subsequent 


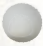

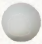

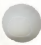


management is mutually agreed upon by BLM and the state agency.

G. Wildlife: All species of aquatic, marine, avian, and terrestrial animals, both native and exotic, normally found in a wild state. Feral horses and burros are excluded.

H. Wildlife/Plant Habitat. All elements of a wild organism's environment which the organism's needs to complete its life cycle normally and naturally, i.e., to maintain a healthy $l$ ife and perpetuate ita population through normal reproduction. These elements may include, but are not limited to: nutrition, cover, water, and living space, in the amounts, qualities, and locations which the organism requires to complete its life cycle. 
0

0

0 
.11 Plan Objectives and Actions. Specific HMP objectives and actions are based upon decisions obtained through the resource management planning process (RMP).

.12 Prioritieg for Development. State Directors establish HMP preparation and implementation priorities based on BLM District and State critical issues and resultant programs for development and implementation of HMPs within their respective States. These priorities must be in accordance with Section 202 of the FLPMA of 1976 (43 U.s.C. 1712), Title II of the sikes Act (16 U.S.C. et seq.), and the Public Rangeland Improvement Act of 1978 (92 Stat. 1803).

.13 State Agency Planning Coordination. Many state agencies have developed long-term, Strategy Plang for the management of wildlife species and their populations. State Directors must ensure that such State agency planning efforts are consulted, coordinated, and referenced in HMPs. If deemed appropriate, BLM, State, and other Federal agency wildlife planning efforts may be combined at a state or regional level in the form of comprehensive or strategic plans. This can help ensure broad, coordination efforts and assist in the synchronization of HMPs affecting multi-agency lands and resources.

.2 Scope of Plan. Habitat management areas are established to encompass the biological requirements of priority species, regardless of land status. These areas are managed on an ecosystem basis. In this case, the species emphasized is bighorn sheep.

\section{.21 Management Considerations.}

A. Priority Species and Habitatg. Each plan must consider the requirements of priority species and habitats (e.g. bighorn sheep). These may include Federal- or state-listed endangered or threatened species; fish, wildlife, or plants of significant economic or recreational value; species highly sensitive to land-use changes; individuals or populations of special significance; and aquatic or riparian areas or other habitats of special significance. Priority species and priority habitats normally are established in cooperation with appropriate state management agencies.

1. Big Game Populations. Existing MFPs may not contain specified population numbers or vegetation allocation allowances for big game species. In such cases, population levels should be established in the HMP and coordinated with the state agency. These population levels must be consistent with social and economic needs, habitat sustenance capability, and multiple-use management objectives for the area concerned.

2. Threatened and Endangered (T/E) Plants. The responsibility for $T / E$ plants is an integral part of the Bureau's wildilife program. Thus, activity planning for these plants is to be accomplished within HMPs.

B. Ecosystem Manaqement. It is important that managing for or maintaining desired ecosystems be the primary consideration in the development of HMPs. If an HMP is intended to help a particular wildlife or plant species, the primary objective must be to preserve the ecosystem upon which the species depends. This means that all proposed management practices must be designed to ensure the maintenance of a natural or desired diversity of plants, animals, and habitats. The quantity and quality of nutrients, water, food, cover, living space, and the proper mixture of these to meet desired levels of abundance and diversity are major considerations for management attention in the HMP. Human intrusion, climate, topography, and other habitat determinants must also be considered. An HMP should prescribe methods for improving manageable habitat that is a deteriorating condition, and also should specify procedures for maintaining manageable habitat that is already in satisfactory condition.

\section{.22 Administrative Considerations. Habitat management area boundaries are}




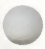

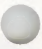

0 
established by the District Manager to address BLM-administered habitat management needs and to facilitate the administration of law enforcement, visitor management, and other administrative programs related to habitat management. Habitat management areas and boundaries should not overlap, except in special cases which require separate HMPs for aquatic habitats. As HMPs are reviged and updated, any overlap in boundaries should be eliminated.

A. Areas of Reserved Federal Mineral Estate. Reserved Federal mineral estate lands (private ownership/federal minerals) are treated as other non-Federal surface lands within the HMP area. The exception is that the HMP must identify, for recommendation purposes, general types of mitigating measures and lease stipulations for surface land management to protect, improve, and maintain wildiffe habitat components. The stipulations then can be used in the formulation of alternatives and mitigating measures in environmental assessments or impact statements. BLM has the responsibility of ensuring that protection measures are taken to prevent detrimental environmental impacts on adjacent non-Federal surface lands and compliance with the Endangered Species Act.

B. Other Land Ownerships.

The Bureau's habitat management responsibility and HMP program applies only to BLM-administered surface lands, except as noted under. 22A, above. Where other land ownerships are involved, the HMP may include appropriate habitat management recommendations and be used as a guide to encourage the respective landowner(s) to implement practices to improve, protect, and maintain wildlife habitat. 
0

0

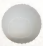


.31 Introduction

\section{.31A Reasons for Preparation}

Preparation of the Laramie Peak HMP originates with the Bureau of Land Management's responsibility for the balanced administration of the public lands and resources and their various values so that they are considered in a combination that will best serve the needs of the American people. This HMP focuses on preserving and enhancing bighorn sheep populations on the public lands (BLM, Great Divide Resource Area, Rawlins, Wyoming and Platte River Resource Area, Casper, Wyoming - see Map 2) intermingled with both private and state lands, located within and adjacent to the USFS Douglas Ranger District (see Map 3). This management is based upon the principles of multiple-use and sustained yield, an amalgamation of uses that takes into account the long term needs of future generations for renewable and non-renewable resources. As stated above, improving and enhancing bighorn sheep populations in the Laramie Range is the principle reason guiding the preparation of this document. To achieve this goal, the Bureau needs the cooperation of the Wyoming Game and Fish Department (WGFD), U.S. Forest Service (USFS), U.S. Fish and Wildlife Service (USFWS), ranchers, farmers, miners, developers, adjoining landowners, timber contractors, recreationists, environmental groups, and the general public. The public lands administered by the Bureau are permanent or seasonal habitat and crucial winter range for over 3,000 species of mammals, birds, reptiles, fish, and amphibians. Manaing the habitat for these species for the benefit of all citizens is a complex task and will require a 10-15 year time span to complete. Appendix I includes pertinent documentation, such as newspaper articles, letters, highlights of public meetings, etc., that substantiates the attitudes of the general public towards the aesthetic, social and economic importance of the bighorn sheep populations within this particular mountain-foothill ecosystem.

Diseases, predators, fire suppression, decreased habitat quality (e.g. restricted travel corridors, overabundance of dense conifer stands, lack of good quality forage), competition, human encroachment, and stress are all factors that have contributed to the decreased bighorn sheep populations in the Laramie Range. Over the years, the WGFD, USFS, BLM, environmental groups (e.g. Foundation for North American Wild Sheep), and the general public have expressed concern over the low population growth and recruitment of sheep due to these factors. These sheep sub-herds are presently located in the Laramie Range, north of Wyoming State Highway 34, east of Wyoming State Highway 487 , and south to south-west of Interstate Highway 26 , which is historically bighorn sheep habitat (see Map 4 ).

Due to the many limiting factors affecting the Laramie Peak bighorn sheep, these sub-herds are becoming more and more isolated in nature (see Map 5). Isolation in wildife herds tends to decrease genetic viability which generates detrimental conditions to the population as a whole. In addition, many factors that may normally have a relatively minor affect on larger, less segregated herds in general (e.g. diseases, reproductive problems) may have significantly larger, more detrimental affects on isolated sub-herds. At this point in time, the remaining bighorn sheep herds are located and managed within the WGFD Hunt Area 19 (see Map 6) which totals approximately 280 square miles of the entire HMP Area; this area was selected to accommodate for the different locations of the sheep sub-herds and associated management practices (e.g. it is easier to manage populations in 1 WGFD Hunt Area versus a mix of areas, personnel). If present conditions continue to progress quid pro quo then it is possible that entire subherds may be obliterated over time.

Although the HMP is a BLM document, the WGFD, BLM and USFS developed a Memorandum of Understanding (MOU) that coordinates habitat improvement projects to enhance bighorn sheep range in the Laramie Peak herds. The MOU includes a list of prioritized treatment areas (15 total) which are the most likely to benefit the sheep populations. A Technical Committee was then formed to coordinate projects, 


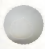

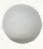

0 


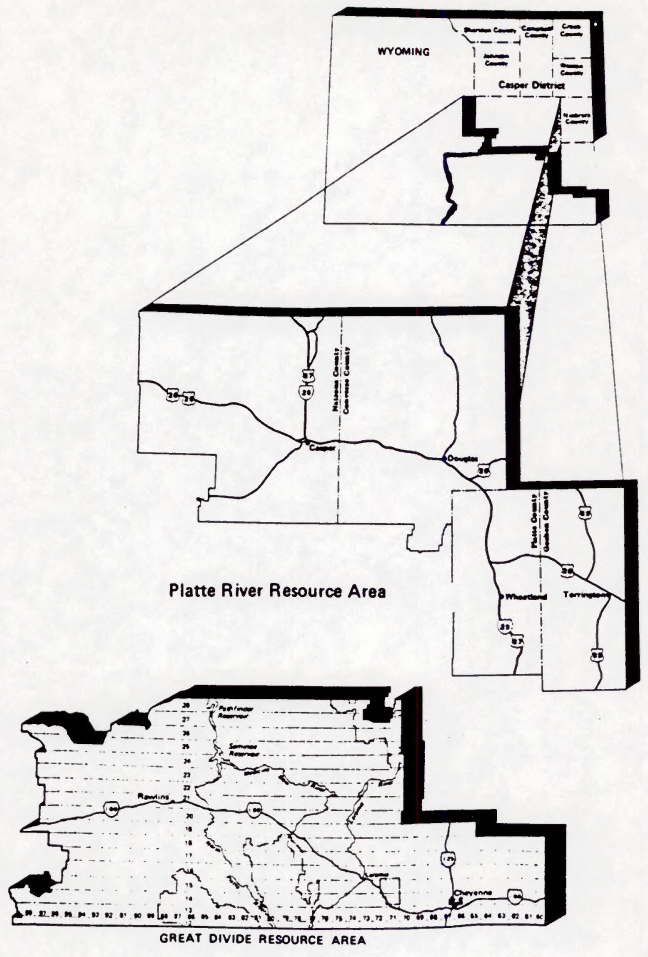

MAP 2

GREAT DIVIDE RESOURCE MANAGEMENT PLAN AREA AND

PLATTE RIVER RESOURCE MANAGEMENT PLAN AREA 


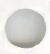

.

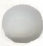




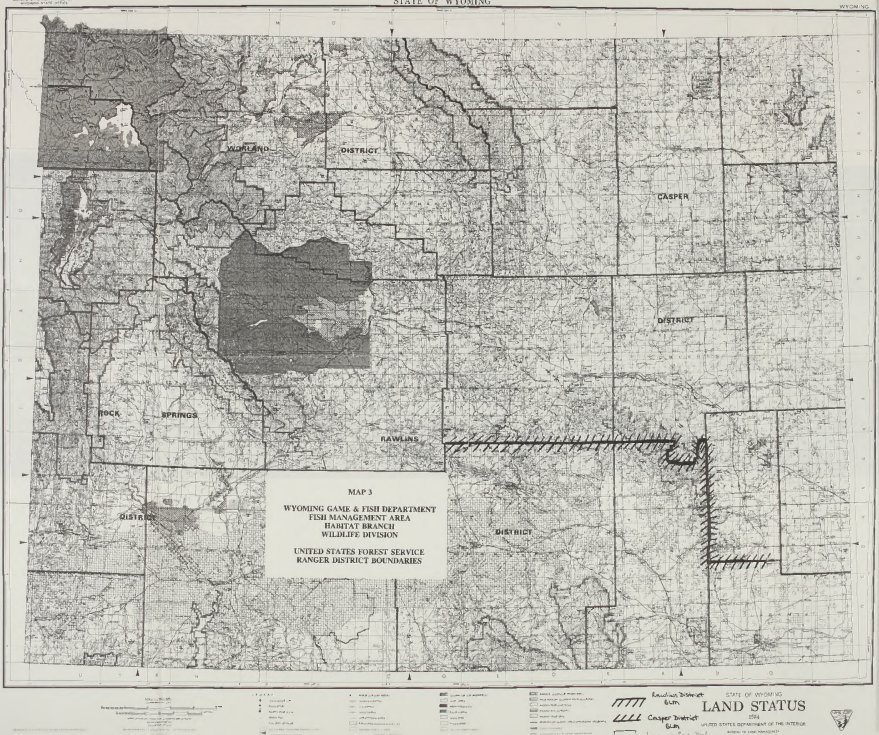



discuss concerns, and view specific areas of interest to sheep management. Appendix I containg a copy of that MOU.

Over the years, the Foundation for North American Wild Sheep, permitees, sportspeople, hunters, and the general public have met with the agencies listed above and have established a need for management of bighorn sheep in the Laramie Peak Range. The Technical Committee and interested parties selected $15 \mathrm{sites}$ to be managed for sheep habitat enhancement. Each area will have a gite-specific Environmental Assessment (EA) planned, implemented and monitored. One sitespecific EA which has been completed, the Split Rock Project (EA No. WY037-EA0038 , signed Feb. 23, 1993, see Append $i x$ ) has been in effect for over a year and is presently waiting for burn prescriptions to ensue. Planned actions to be used in the site-specific project areas required to facilitate the objectives and the overall goal of the HMP include, but are not limited to, prescribed burns, smallscale tree-felling treatments, water developments, fertilization and herbicide treatments, small commercial logging practices, and general wildife management practices.

Since the passage of the Federal Land Policy and Management Act (FLPMA) in 1976, considerable progress has been made in improving management of the public lands for wildlife and fisheries. Although some species have significantly increased in population $\mathbf{s i z e s}$ (e.g. elk, antelope), others have remained fairly stable or reflect a decline in population numbers--including bighorn sheep. In addition, over the next decade, the U.S. population is expected to increase about 7 percent with a strong shift towards the West and South; this will create yet a greater demand for natural resources which will result in a greater impact on bighorn sheep populations and their associated habitats. A Habitat Management Plan (HMP) is designed to improve particular wildlife or plant species population levels, through the use of comprehensive plans (as provided for in Title II, Secs. 202 (a) (2) and (b) of the sikes Act), and are prepared and implemented to concentrate on priority species and their habitats (see Sec. .01-.22). This HMP focuses on the population levels and viability of bighorn sheep populations, relative to the social and economic needs of the general public, habitat sustenance capability, and multiple-use management objectives for the area concerned.

\section{B Ecosysten Description}

The Laramie Peak HMP encompasses approximately 2,045, 300 acres and is $10 \mathrm{cated}$ in R. 68 W. - R. 78 W., T. 19 N. - T. 33 N. (see Map 1). The area is within two (2) BLM Districts, the Great Divide Resource Area (GDRA) and Platte River Resource Area (PRRA) and is managed under both the Great Divide Resource Area Resource Management Plan (GDRA RMP, signed Nov. 1990) and the Platte River Resource Management Plan (PR RMP, signed July, 1985). The area also included USFS lands and state lands as well. The isolated populations of sheep herds are located in an area that is approximately 180,000 acres ( 280 square miles) within the HMP Area.

The planning area contains many diverse wildlife habitat types that have unique vegetative composition and structure to support specific wildlife communities. The HMP habitat types can be grouped into eleven (11) major vegetative types: grass, meadow/riparian, sagebrush, greasewood, saltbush, mountain shrub, broadieaf trees, conifer, juniper, rockland, and barren. Appendix II lists the precipitation zones, the major range sites, and the common plant species within each vegetative type. The diversity of habitat types include renewable and nonrenewable resources for recreation, range, forest, minerals, watershed, fish and wildlife, wilderness and natural, scenic, scientific, educational, and cultural values. In addition, a complete list of fish, mammals, birds, reptiles, and amphibians, as well as threatened and endangered species, is included in Appendix III. There are also numerous invertebrates within the HMP Area, but a complete list of specific species is not available at this time.

$$
.31 \text { B.1 Bighorn Sheep Population Dynamics }
$$


0

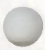

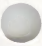




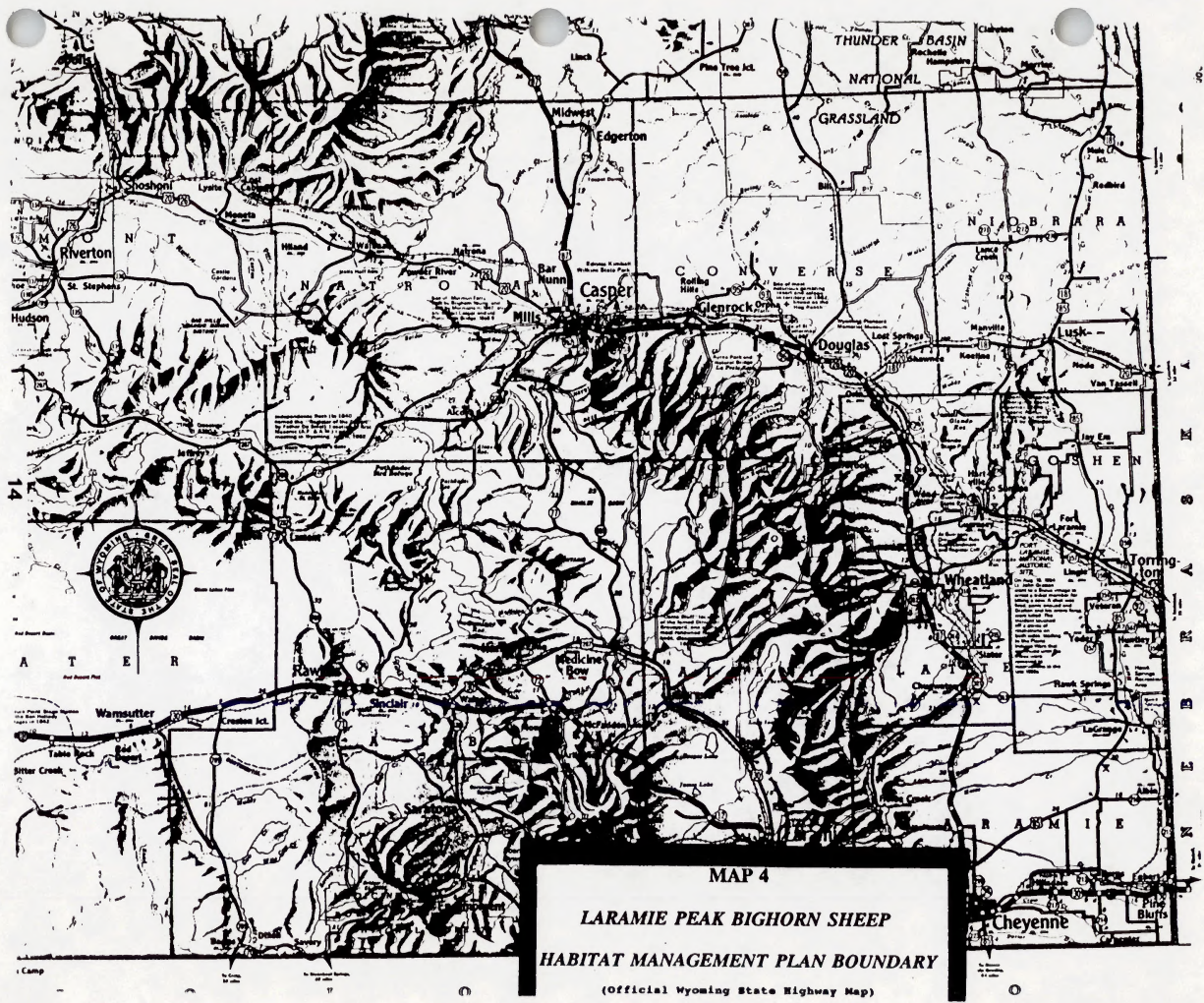




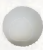

0

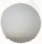




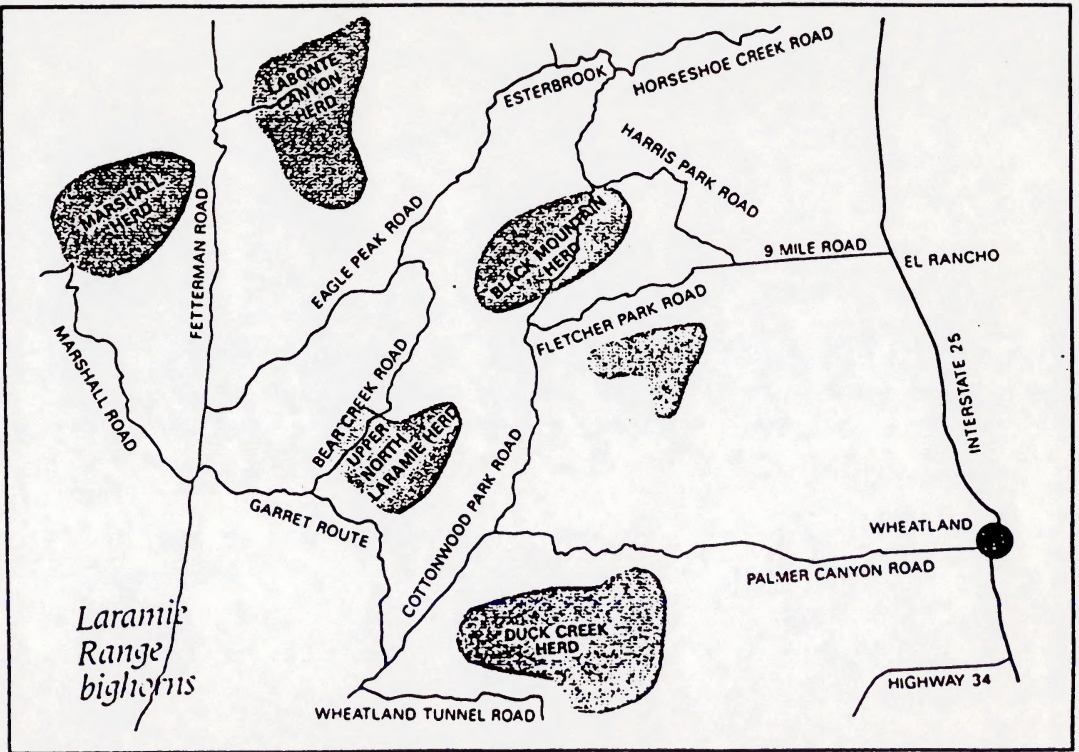

MAP 5

LARAMIE RANGE BIGHORN SHEEP HERDS 
0

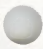

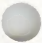


The purpose of this HMP is to provide a mechanism to improve and enhance bighorn sheep populations in the Laramie Range within the HMP Area. The planned actions that will be used to reach the objectives and goal of the HMP are to plan, implement, and monitor activities in 15 different locations utilizing a diversity of actions. There are several bighorn sheep sub-herds located within the HMP Area that basically outline the diverse site-specific project areas that require habitat enhancement (see Map 7). Due to specific population dynamics, these areas are prioritized according to immediate and future needs. The bighorn sheep habitat types are also described in this section. Historical activities that affect the current population attributes must be considered to understand how and why these sub-herds have become both naturally and physically isolated. Population objectives determined by the WGFD and the modeling techniques used to obtain data must also be considered for this HMP, especially since these herds are both isolated and dispersed, are located in rugged terrain/habitat, and are difficult to observe and monitor at times. Hunter/harvest statistics, as determined by the WGFD, are described since these animals are an important social, aesthetic, and economic species for many local Wyoming, as well as outof-state, residents (see Appendix I).

\section{.31B.1.a Bighorn Sheep Sub-Herd Locations Within the HMP Area}

Historical records show that sheep were once abundant in the HMP Area. As human activity increased within the past 100 years, these sheep were locally extirpated -- although small, localized concentrations of herds appeared to remain scattered throughout the Laramie Range. Additional sheep were then reintroduced via several small transplants. Today, sheep are presently contained within the Marshall, LaBonte Canyon, Black Mountain, Fletcher Park, Duck Creek, and Upper North Laramie Herds. The smaller sub-populations of these six (6) herds exist around Sellers Mountain, the North Laramie River and Bearhead Mountain; LaBonte Canyon and upper Horseshoe Creek; Laramie Peak, Albany Peak and Cottonwood Creek; Marshall; lower North Laramie River and Johnson Mountain; and Sybille Canyon (see Map 5). The largest portion of the bighorn sheep herd is centered around steep rocky cliffs and outcrops of the Laramie Peak Wildlife Habitat Management Area in the Laramie Range.

There appears to be limited amounts of seasonal movements between these subherds, but the majority of this is confined to the northern portion of the sheep range. Interchange of sheep between southern sub-populations appears to be limited at this time, however, there have been some rams located outside of the main sub-herds in recent years. It should be noted that additional sheep sometimes occur outside of these herds in the Iron Mountain area.

Although there have been numerous sheep transplants throughout the decades, the last transplant that did occur was in January of 1989 in the Marshall area. A total of 20 sheep were trapped on the Whiskey Mountain Winter Range (BLM Ridge) and transplanted to the Marshall area. These sheep were released behind the Jim Robbin's Ranch which is legally located in R. 75 W., T. 27 N., Sec. 5, NWSE. These particular sheep were ear tagged.

\section{.31B.1.b Bighorn Sheep Habitat Types}

The habitat requirements for bighorn sheep seem to be keyed to good foraging sites near escape cover (rough terrain). Research has shown that bighorns prefer open grassy ridgetops, slopes, or benches within 100 meters of rocky outcrops, precipitous cliffs, or steep rocky slopes. Habitat types most commonly used are rockland, upland meadows, sagebrush-mixed grass, big sagebrush-rabbitbrush, and mountain shrub. These habitats provide forbs and grasses, the major components in bighorns' diet from late fall to early summer.

Sagebrush, rabbitbrush, and bitterbrush are the principal winter browse species that become especially important during periods of deep snow. Bighorn sheep in the Seminoe Mountains to the west utilize yellow alfalfa in their summer and fall diets as well; the sheep of the Laramie Range probably do the same when given the opportunity. 


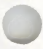

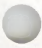

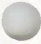




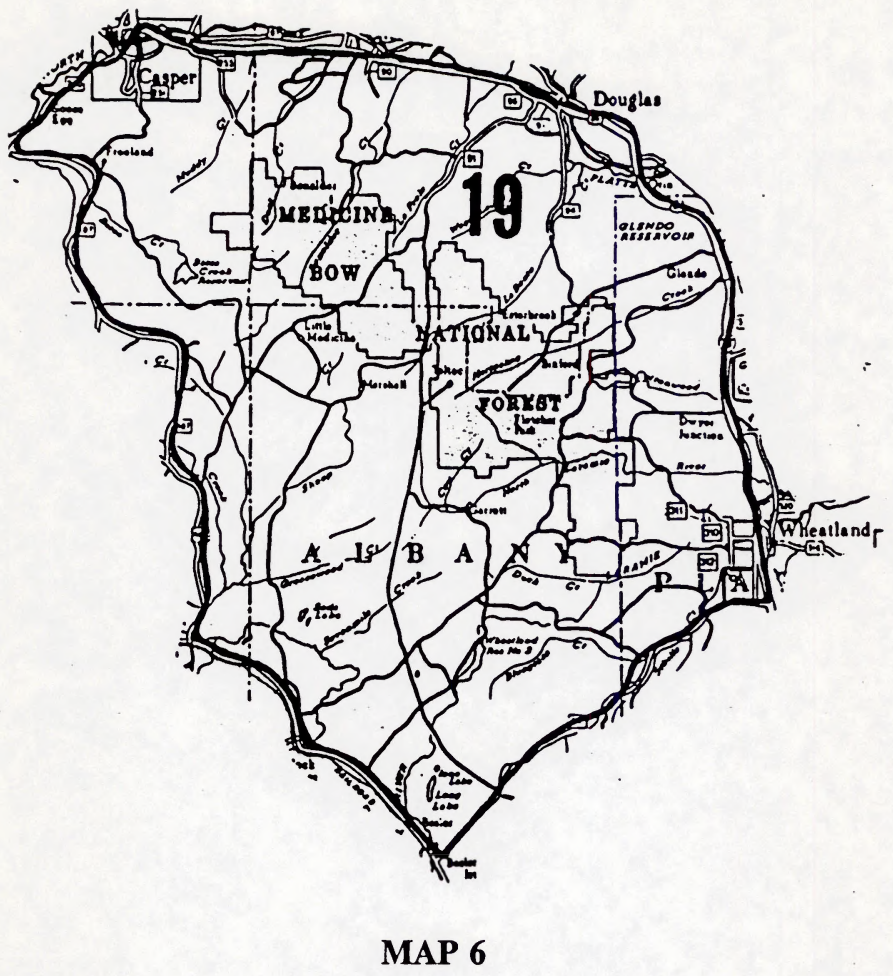

\section{LARAMIE PEAK BIGHORN SHEEP}

HUNT AREA 19

DAU (DึHS517) 
0

0

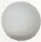


Good quality habitat does exist generally throughout the range, but the amount is limited, and indications are that the relative abundance of bighorn sheep in the population levels (WGFD, 188 sheep in 1992 dropped from a five year average of 216 sheep from 1988-1992) reflects a decrease in habitat availability. Poor habitat quality in the Laramie Range may be the ultimate cause of population declines since the early $1980^{\prime} \mathrm{s}$. Since habitat quantity and quality play such a vital role in the overall success in the sheep populations, it may be beneficial if the USFS and the BLM revise allotment management plans in the area; livestock-sheep conflicts over habitat, as well as depleted conditions of habitat, are known to occur which puts additional gtress on the population.

Relative to bighorn sheep habitat types, it should be noted that due to the ruggedness of the terrain, weather conditions, and scattered distribution and mobility of the sub-herds, data is often difficult to collect. The habitat is remote and often data must be collected via aerial gurveys and ground truthing, which is not always feasible in some localities and conditions. The inability to collect adequate population data due to the remoteness and terrain often leads to difficulties in modeling the sub-herds.

\section{.31B.1.C Historical Activities Affecting Current Bighorn Sheep Populations}

There are numerous activities that are affecting the sheep populations in the Laramie Range. The most serious problem facing bighorn sheep today is a lack of suitable habitat for foraging, resting, parturition, and wintering -- the majority of this is due to increased forest succession. Other activities that supplement pressures on these herds are due to human encroachment, recreation activities on crucial ranges and overgrazing by livestock. Fire guppression in the area has generally allowed for unnatural forest succession and associated decrease in early successional habitats (e.g. mountain meadows). In addition, numerous acreages of forests with diseased/dead trees (mountain pine beetle) are still standing, which, under normal fire conditions, would have been opened up and naturally subsided towards early successional habitats.

Fire suppression over the past century has had a negative impact on the vegetation condition (browse/forage viability) in both the crucial winter range as well as the fall, spring, and summer habitats. Habitats that were once a mosaic of varying age classes currently have numerous and large gtands of decadent and or dead mountain pine beetle killed trees. Due to these large stands, any wildfires in such areas, at this time, has the ability to be vast in size and scope. It is difficult to predict the outcomes of any such events, however, if the fires are too extensive then irreplaceable damage may occur to the soils and vegetation. Smaller, more controlled burns can avoid undesirable damage to both the soils and vegetation, will recover the diversity and viability of stands and mountain meadows, and may be beneficial to bighorn sheep and other wildife in the area.

Historically, two (2) large wildfires burned near Collins Peak and Three Cripples creek in 1986. These fires removed extensive areas of ponderosa pine forest near escape areas used by sheep. Four (4) other fires have occurred in the HMP area since the 19708 near Government Peak, Duck Creek, Bearhead Mountain, and Sheep Mountain. Today, all these areas are utilized by bighorn sheep. It is basically these types of events, in a controlled manner, that the planned actions of the HMP is attempting to replicate.

\section{.31B.1.d Population Objective/Modeling for Bighorn Sheep Herds}

The postgeason population WGFD objective for the Laramie Peak bighorn sheep herd is 500 animals. The WGFD uses a POP-II model for estimating population numbers. Difficulties derived from inadequate samples, ruggedness/remoteness of the terrain, and unequitable sample sizes and coverage confounded modeling attempts for 1993 (latest data published). This model does include "harvests" on lambs to account for higher age-specific mortality occurring after preseason classifications and to better align the model. 
0

0

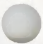


Present model simulations estimate a total of 173 sheep for the 1993 postseason Laramie Peak population. There appears to be a declining trend in population numbers since the $1970^{\prime} \mathrm{s} / 1980^{\prime} \mathrm{s}$. The average herd size from $1988-1992$ was 218 sheep. The 1992 herd size estimate was 188 sheep. The 1993 estimate of 173 sheep therefore reflects a 168 decline in the population from the 1989-1993 period. The 1994 season for the Laramie Peak bighorn sheep herd prescribed four (4) licenses (the same number as 1987).

The POP-II model assumes no natural mortality occurs during the hunting season from September 1 - october 31. Significant lamb mortality appears to occur after the prehunt data are collected and prior to posthunt data collection. High lamb mortality has been noted for the Laramie Peak herds in 1986, 1989, 1990 and 1992. specifically in late summer and fall. These losses may be from poor nutrition and diseases.

In 1993, only 37 different sheep were classified in preseason surveys. This did not meet the required 808 confidence level sample size of 162 sheep. Difficulties in sampling due to terrain, decrease use of helicopters, decreased manpower, scattered sub-herds and weather did not allow for adequate sampling to occur in 1993.

Postseason classifications showed ratios of 12 rams/100 ewes/21 lambs for 1992 compared to $26 \mathrm{rams} / 100$ ewes/46 lambs in 1991. Ram:ewe ratios have averaged about $60 / 100$ from 1988 - 1990, in 1992 the ratios were averaging $19 / 100$. It should be noted that there were only 3 rams observed in 1992 and in general, ram/ewe ratios tend to underestimate the true proportions. Although rams are difficult to account for, the declining trend in the proportion of yearling rams observed in postseason classifications is consistent with poor lamb recruitment. A ratio of 40 rams/100 ewes was obtained during the 1993 preseason classification.

The 1992 postseason classification showed a ratio of 21 lambs/100 ewes as compared to the 1991 ratio of $46 \mathrm{lambs/100}$ ewes. The 1993 preseason classification showed $45 \mathrm{lambs} / 100$ ewes, however, this was calculated prior to the typical lamb mortality period. There appears to have been a better recruitment of lambs in 1993 versus previous years. The 1991 ratio has been the highest observed since 1988 (WGFD, 1994).

Poor nutrition affecting lactating ewes with lambs has been hypothesized as a factor affecting lamb survival in the Laramie Range. Results from the Laramie Peak Bighorn Sheep Study indicate that lamb production and survival were higher in the North Laramie River subherd than in other intensively monitored subherds due to the availability of higher quality diet. Displacement of ewes with lambs from riparian zones when cattle were present has also be observed (Hengel et al., 1993). Forage quality reductions are known to cause simultaneous reductions in milk productions as well; in addition to these factors, stress and lack of sufficient habitat predispose sheep, especially ewes and lambs, to diseases, predators, and low winter survivability.

Based on casual observations from local residents, outfitters, sheep hunters and agency personnel, the population levels of bighorn sheep in the Laramie Range appear to be declining since the $1970^{\prime} \mathrm{s} / 1980^{\prime} \mathrm{s}$. In general, the population appears to have undergone a significant decline from 1982 to 1986 . Young rams a lso appear to be decreasing in population size, and there appears to be a reduction in lamb recruitment as well. Harvest of rams has decreased over this time period. Confidence in the model used to estimate population levels is low; it is possible that the population could be larger than is currently estimated even if observed trends are accurate (WGFD, 1994).

\section{.31B.1.e Harvest/Bunter Statistics for Bighorn sheep}

The 1992 and 1993 hunting season allowed for 4 bighorn sheep ram licenses, and in each year only 1 ram was harvested. The 1988-1992 period averaged a 2 ram harvest. Rams appear to be difficult to locate according to the statistical results and reports from the local people. The WGFD states that there is an 


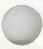

0

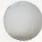


adequate population to support the 4 license target, yet due to the trend in the overall decline of the population, consecutive years of low lamb recruitment, and higher non-hunting mortality of sheep, additional tags are not warranted at this time. It should be noted that from 1979 to 1983,8 icenses were available and 7 rams were harvested in 1983.

Hunter success rate for both 1992 and 1993 was 258 . Four (4) hunters participated in the 1993 hunt. The 1990 success rate was 508 and the 1991 success rate was 758. The 1993 season averaged 63 recreation days per harvested sheep versus 41 recreation days per harvested sheep in 1992; obviously this shows that there is currently a greater effort to harvest sheep than in previous years. Days per animal have been averaging 59 over the 1989-1993 period (WGFD, 1994).

\section{.31B.2 Other Fish and Wildlife Species/Seasonal Occurrence by Habitat Type日}

There are numerous other species of wildlife in the Laramie Peak HMP area that include both large ungulates, smaller species and their associated predators. Big game species occupy broad landscapes and require diverse plant communities in fulfilling yearlong habitat requirements. Managing resources to preserve and conserve large ungulate species such as bighorn sheep must utilize an ecosystem approach and can aid in the conservation of other wildlife species as well. In completing the objectives of the HMP, the plant communities (forage and cover in high priority habitat types) can be restored, maintained, and improved to sustain viable big game populations and subsequently small game and other wildife species. In addition to sustaining a diversity of species, population abundance levels can be maintained to meet both wildlife population requirements, as well as, the social, economic and ecological demands of the general public.

Ecosyotem management for big game wildlife resources is more complicated than the management of other renewable resources due to the mobile nature and fluctuation in numbers of big game through time under normal climatic conditions. Addressing the requirements to improve the health of bighorn sheep populations concurrently addresses overall biological diversity (via an HMP approach); this occurs on an ecosystem level and will require the cooperation of State and Federal agencies, other landowners, and the general public. Site-gpecific Proposed Project Area EAs that are planned and implemented over a longer time span (i.e. 15 projects over 10-15 years) will enable wildlife habitat managers to properly ascertain specific needed requirements and actions -- many of which will diverge over time as populations increase/decrease in size.

Appendix IV contains numerous maps portraying the crucial winter ranges for large ungulates, as well as WGFD Hunt Areas, for both BLM Resource Areas. Appendix V shows the breeding/nesting habitat areas for sage grouse and crucial winter habitat for turkeys. In addition, there are some larger predators in the area as well that are included in Appendix VI, along with associated WGFD Hunt Areas. These predators play a critical role in the development and mortality rates of ungulates, small game, and birds within specified habitats of the HMP Area.

\section{.31B.2.a Big Game Habitat Types}

The HMP area is relatively large and provides summer, winter/yearlong, and crucial winter range for numerous species. The Great Divide Resource Area portion of the HMP area includes approximately 15,400 acres of elk crucial winter range, 10,400 acres of mule deer crucial winter range, 7,100 acres of antelope crucial winter range, 11,520 acres of bighorn sheep crucial winter range, and 49,700 acres (15 leks) of sage grouse nesting areas. At this time, the exact acreage for big game crucial winter ranges is not known for the Platte River RA portion of the HMP, but there are only two (2) full and three (3) partial projects in the PRRA, therefore acreage determination can be addressed in individual EAs for that area.

The Laramie Peak HMP Area provides summer, winter/yearlong, and crucial winter range for approximately 3,140 elk. Elk require a combination of feeding sites 
0

0

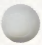


(upland meadow, sagebrush-mixed grass, and mountain shrub), security, and thermal cover (aspen and conifer woodlands). During the summer, elk tend to use the higher elevation woodland types for security and thermal cover, and the upland meadows and sagebrush-mixed grass sites for forage. Elk concentrate on the lower elevation crucial winter ranges during periods of severe weather. Livestock grazing can conflict with elk management, depending on its intensity. The 1993 harvest for WGFD Hunt Areas 7, 19, and 20 (HMP Area) was 700 elk (518 success rate); the WGFD objective for elk in this area is 2,550 animals.

Mule deer are also distributed throughout the seasonal ranges in the Laramie Peak HMP Area. In general, mule deer prefer habitat types that are in the early stages of plant succession and contain a large quantity of shrubs. Mule deer use the woody riparian, shrublands, juniper woodland, and aspen woodland habitat types extensively during spring, summer, and fall. These types provide adequate forage areas with security cover, as well as cover for fawning and succulent vegetation for lactating females. Mule deer tend to winter at lower elevations in the juniper and limber pine woodland, big sagebrush-rabbitbrush, bitterbrushsagebrush steppe, and riparian habitat types. White-tailed deer utilize the willow-waterbirch and cottonwood habitat types along the major creeks and rivers. Population numbers (1992) for mule deer and white-tailed deer in the HMP Area were calculated from an approximation of combined numbers from WGFD Hunt Areas 64 and 73 (approx. 908), Hunt Area 70 (approx. 508), Hunt Areas 66-69 (approx. 758 ), and Hunt Area 65 (approx. 958) and are estimated at 39,452 deer. The WGFD objective for deer in the HMP Area is 41,500 animals.

Pronghorn antelope are the most abundant and visible big game species in the HMP Area. Antelope inhabit open rangelands with a wide variety of habitat types rather than a monotypic vegetation community. These types tend to have a high density of grass, forbs, and shrubs (particularly sagebrush) that produce an abundance of succulent vegetation. Population numbers for pronghorn antelope were calculated using the combined approximation from WGFD Hunt Areas $31-33$ (approx. 958), Hunt Areas 30 and 103, Hunt Areas 41, 42 and 47 (approx. 908), and Hunt Areas 38,39,40 and 104 (approx. 258) and are estimated at 35,270 antelope. The WGFD objective for this area is 40,750 antelope.

\section{.31B.2.b Upland Game Bird Habitat Types}

There are three (3) types of upland game birds that inhabit the HMP Area ecosystem. These birds include wild turkey, sage grouse, and blue grouse. Upland game birds are chicken-like in appearance, live on dry ground near water, and usually do not migrate, but adapt to seasonal changes. Appendix $V$ describes sage grouse breeding/nesting areas and turkey crucial winter areas in the GDRA and PRRA locations.

Sage grouse are the most common and widespread game bird in the HMP Area, although population levels at this time are questionable (see Appendix V). A complete list of the location and status of both active and historical strutting grounds is available at both the BLM Platte River Resource Area in Casper, Wyoming and the Great Divide Resource Area in Rawlins, Wyoming. During the spring, sage grouse concentrate on traditional strutting grounds for courtship and breeding; these are located in openings where adjacent canopy averages at least 328. These birds nest under sagebrush on drier sites, however they tend to avoid large stands of dense sagebrush; the majority of these nests are located within 2 miles of the strutting grounds. Water can be a habitat-limiting factor to these populations since grouse tend to stay within $1.5 \mathrm{miles}$ of water during warm, dry summer periods, and riparian areas are used by hens in the spring and summer. Appendix VIII provides protection measures for sage grouse wintering areas. Livestock grazing, sagebrush spraying and conversion practices, disturbance of nesting hens, mineral exploration-surface disturbance, failure and or abandonment of key water projects in dry areas, and de-watering of lower sections of the HMP Area are all factors that contribute in one form or another to the decrease in sage grouse populations in parts of Wyoming.

There are some populations of blue grouse within the HMP Area since this species 
0

0

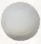


is associated with forest fringes within the Medicine Bow National Forest. These birds prefer habitat sites that include mountain shrubland; aspen-conifer, quaking aspen, and limber pine woodland; lodgepole pine and ponderosa pineDouglas fir forest, logging lash, burned over timberland, and sub-alpine clearings. The optimum habitat for blue grouse is aspen meadows intermixed with unevenly aged conifer stands. The edges between these types and small riparian areas within these types are especially preferred. Breeding, nesting, and broodrearing areas are typically in the edge areas. Fire and timber harvesting operations can damage or destroy blue grouse habitat. These activities can also have beneficial effects if proper vegetative structure and diversity are created or restored as a result of the activity.

Extirpated from most of its original range, the wild turkey has been widely reintroduced and does occur within the HMP Area. This species inhabits open woodland, meadows, and forest clearings. Turkeys usually roost in trees at night. Habitats that provide acorns, fruit and seeds are preferred by the turkey. Crucial winter habitat within the HMP Area encompasses open timberland, mountain forest, logged areas, and open prairies where food is available during the colder winter months (see Appendix v).

\section{.31B.2.c Raptor Habitat Types}

At this time, there are not any defined raptor concentration sites within the HMP Area, however, raptors do use the habitats along the rivers, cliffs, rocky outcrops and open areas. Due to protection measures, a map depicting raptor nest locations will not be displayed in this HMP document. Raptors (birds of prey) found throughout the HMP Area include eagles, falcons, hawks, harriers, and owls. Since these species occupy an ecological position at the top of the food chain, they can act as biological indicators of environmental quality. A complete list of raptor species can be obtained at the GDRA in Rawling, Wyoming (see Appendix III). Two species, the peregrine falcon and the bald eagle, are listed as endangered by the USFWS (at this time the bald eagle is considered for downlisting to "threatened"). The ferruginous hawk is a "category 2 candidate" species on the USFWS list of candidate species for threatened or endangered status.

Most raptor species have specific nest site requirements such as nesting strata, availability of prey base, and freedom from nest site disturbance. The nestingreproductive season is considered to be the most critical period in the raptor life style since it determines population productivity, short-term diversity, and long-term trends. Raptors will often concentrate their nests along cliffs or other formations and use these areas for nesting year after year. The greatest impact on raptor production and population trends is human disturbance at the nest site during critical periods (incubation is the most critical period).

$$
.31 \mathrm{~B} .2 \cdot \mathrm{d}
$$
Waterfowl, Shorebirds, Neotropical Miqratory Bird Habitat
Types

Appendix III contains a list of common and threatened/endangered species of waterfowl, shorebirds, and neotropical migratory birds. The abundance of waterfowl/shorebird species varies from year to year depending on availability of water resources in the HMP Area. Wetland-riparian habitat, such as natural streams, lakes, and ponds, as well as constructed reservoirs, provide nesting and brood-rearing habitat for numerous species of ducks, geese, and shorebirds. Heavy grazing can be a problem (e.g. trampling, removal of nesting cover) in the majority of the riparian zones of streams, lakes, and reservoirs - major habitats needed by these species.

Numerous species of neotropical migratory birds (songbirds) occupy various habitats throughout the HMP Area. Usually, the highest number of species of songbirds are found in woody riparian habitats, especially where this habitat interfaces with sagebrush-steppe and coniferous habitats. Most nongame birds are migratory; they begin arriving to the HMP Area in mid-March and normally are gone by late September. 
0

0

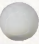




\section{.31B.2.e Predator and Trophy Game Habitat Type}

The diversity of habitat types within the HMP Area create numerous niches for furbearers, predators, and trophy game that affect ungulate and small wildife populations in the ecosystem. The main furbearer species trapped for commercial purposes within the HMP Area include the coyote, red fox, bobcat, mink, beaver, and badger. Historically, bobcat and coyote have been heavily exploited due to increased fur prices, although currently these prices have dropped in value. Black bears and mountain lions are considered trophy animals in the state of Wyoming. Calculations from the WGFD state that in 199211 black bear and 18 mountain lions were harvested in the HMP Area. Appendix VI shows the general location of predator habitat included in the WGFD Hunt Areas in the HMP Area.

Beaver are found in many perennial streams in addition to ponds and lakes. The preferred habitat will usually contain willows and/or aspen species associated with forest fringes and willow-riparian areas. Black bear usually inhabit the forest fringes and riparian areas within the HMP Area as well. In Wyoming, mountain lions prefer habitats that contain conifer woodlands and juniper, mountain shrub, and rockland habitat types.

\section{.31B.2.f Riparian Areas - Fisheries, Reptiles, Amphiblans Habitat Types}

The Laramie Peak HMP Area contains numerous streams, creeks, and riparian drainages that must be managed to achieve a healthy and productive habitat for wildife, including fish, reptiles, and amphibians, Riparian areas include intermittent, perennial, and ephemeral watersheds. Although the riparian habitats make up less than 18 of the public land in the HMP Area, they are often the most heavily favored habitats by livestock and wildlife. Riparian areas, which are directly associated with and dependent upon localized availability of water, produce large quantities and excellent quality of forage in relatively small areas; these areas tend to get "hammered" under high use conditions. An HMP approach to livestock/wildlife/riparian habitat conflicts can mitigate negative impacts that have accrued with continual, unchecked use of these critical areas.

The waters within the HMP Area have not been presently mapped into standard habitat types in the USFWS's National Wetland Inventory. Many fish, reptiles, and amphibians are totally dependent upon the open water habitats, and these habitats are extremely sensitive to human disturbance. Game fish species are limited by harsh and variable climatic conditions, watershed conditions (range from poor to excellent, up-stream water quality factors) and overall limited habitat requirements (e.g. lack of woody riparian vegetation). Several species of amphibians (frogs, toads, salamanders), reptiles (turtles, lizards, snakes) and fish inhabit the many perennial streams throughout the HMP Area. The relatively short summers and long, cold spells through mid-spring make environmental conditions too harsh too support a wide variety of reptiles and amphibians. The presence or absence of beaver ponds is perhaps the major factor determining habitat quality of streams in the HMP Area. A list of species occurring in the HMP Area for both common and threatened/endangered $f$ ish, reptiles, and amphibians is found in Appendix III.

\section{$.31 \mathrm{C}$ Relevant Constraint:}

In summarizing the relevant Departmental and/or Bureau policies, RMP decisions, laws and other general program constraints, it is necessary to remember that many of the directives contained in the various laws, regulations, Departmental policies, and Executive Orders are subject to interpretation. Bureau policies guide managers in the planning and decision-making processes utilized for sound environmental management of the public lands. Appendix VII lists a general framework of guidance for the Bureau's Fish and wildlife Program which contains the BLM Fish and Wildlife 2000 Program (a National Program) that enables the BLM agency and associated personnel to plan, implement, and monitor projects to 
0

0

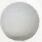


enhance habitat for wildife species.

In meeting Bureau responsibilities for fish and wildlife activity planning and related habitat management on BLM-administered lands, it is Bureau policy that:

A. All HMPs must be prepared and implemented in consultation and coordination with state agencies or other appropriate agencies in the case of plants. HMPs also will serve as "comprehensive plans" as provided for in Title II, Secs. 202(a) (2) and (b) of the sikes Act, if so determined mutually by the BLM and the state agency. It is recommended that as many HMPs as possible be covered under Sikes Act authority.

B. An RMP or MPP must normally be completed prior to the development and approval of an HMP. Where special circumstances so warrant, an HMP may be prepared and implemented prior to the development of an RMP or MFP if it is so approved by the state Director. The Great Divide Resource Management Plan has been completed as of November, 1990. The Platte River Resource Management Plan has been completed as of July, 1985.

c. HMPs are prepared and implemented to concentrate on priority species and their habitats. Subsequently, the geographic areas covered by HMPs are generally more limited in size in order to focus the required special management attention. It may not be necessary to prepare HMPs for all fish, wildlife, or plant habitat and geographic areas within a state or District assuming that such habitat is properly considered and included within an activity plan for another resource. If such is the case, the relevant activity plan will prescribe those actions necessary to improve, protect, and maintain the habitat and species involved and define the funds and personnel required to implement the actions. HMPs and Allotment Management Plans (AMPs) should be coordinated for preparation and implementation to the fullest extent possible to avoid duplication of effort and save costs.

D. Funding priority for habitat development project work is given to those HMPs implemented under the sikes Act, unless otherwise justified by the state Director and subsequently approved by the Director.

E. State Directors and District Managers should strive to establish a balanced mix of "new," "completed," and "implemented" HMPs, such that varied geographic locations can receive habitat development funding and attention during different FYs. In addition, these officials should prepare long-term schedules of project survey and design actions to precede actual, on-the-ground project work. This not only demonstrates positive accomplishments but indicates readiness for future work.

F. HMP project work must receive proper maintenance, within allocated fund availability, to protect BLM, state agency, and other investments and the improved habitat conditions which result.

G. Wildlife habitat development work and related fund expenditures are usually limited to areas covered by HMPs. However, such work may be completed outside HMP areas if deemed appropriate and so approved by the state Director; e.g., improvement of wildlife habitat within AMP areas. Other circumstances warranting such action include those previously defined under paragraph $B$ above.

H. Consultation with other Federal agencies, State agencies, and local governments is required during HMP preparation and implementation where their administrative lands are adjacent in the habitat management area. $A$ special effort should be made to coordinate BLM Sikes Act HMPs with similar plans of the U.S. Forest Service. It may also be necessary to obtain HMP input and review from organizations, universities, or private individuals if their particular expertise is essential to successful HMP implementation.

Other constraints that must be considered when completing HMPs are the Legislative and Executive direction that the U.S. government has determined for 
the Bureau's Fish and Wildlife program. Appendix IX contains descriptions of both the Legislation and Executive orders that drive wildlife programs within the BLM. These acts also detail the authority of the BLM to implement HMPs. These acts and orders must be adhered to when planning, implementing, and monitoring all planned actions within the HMP Area.

In addition to these constraints, the "Wyoming BLM Standard Oil and Gas Lease Stipulations" were developed in 1986. It was recognized that various land uses, other than those related to oil and gas exploration and development, should be subject to similar kinds of environmental protection requirements. Any program activity executed through this HMP must use the mitigation guidelines as stipulations or as conditions of approval of projects (planned actions), or as a baseline for developing apecific stipulations for a given activity program (e.g. activities involving big game crucial winter range). The application of these standard mitigation guidelines, which are located in Appendix VIII, to all surface and other human presence disturbance activities concerning BLMadministered public lands and resources will provide uniformity in mitigation specifically that which has occurred in the past added to that which will most likely occur in the future.

Any relevant constraints concerning land management issues relative to the WGFD are located in the most recent document (1984-1989) titled, A Strategic Plan for the Comprehensive Management of Wildlife in Wyoming. Appendix XI details any constraints pertinent to any of the planned activities within the Laramie Peak HMP Area. Also included in this Appendix is the WGFD's strategic plans for bighorn sheep. This is the most current copy available concerning such constraints.

The USFS has completed a land-use management document that does contain relevant constraints to any activities that will occur in the Laramie Peak HMP. The document, the USF''s Land and Resource Management Plan. Medicine Bow National Forest and Thunder Basin National Grassland, was signed in October of 1985 . At this time, this document is currently being revised, but has not yet been completed. Any restrictions pertaining to land-use activities can be located in this document; a copy is on file at the GDRA in Rawlins, Wyoming or local UsFS of $\mathrm{fice}$.

\section{Sikes Act Authority}

\section{.310.1 Objectives of the Act}

The objectives of the BLM's Sikes Act wildlife program are to implement the intent of the Act and its congressional mandates. The major objectives of the Act pertinent to this HMP are defined as follows (reference to sections of the Act in parenthesis):

1. Develop comprehensive plans in cooperation with state agencies to plan, develop, maintain, and coordinate programs for the conservation and rehabilitation of wildlife, fish, and game (sec. 202(a)(1)). These plans are the HMPs that are integrated with other public land resources and values.

2. Maintain close working relationships, coordination, and cooperation with State agencies in all aspects of the Bureau's wildlife program (Sec. 202 (c)).

3. Implement specific habitat development projects and related improvement, protection, and maintenance (Sec. 201(a)).

4. Provide adequate protection for species considered threatened or endangered, including both federally listed and state-1isted plants and animals (Sec. $202(\mathrm{C})(3))$. 


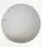

0

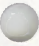


5. Control off-road vehicle traffic in a manner compatible with relevant wildlife habitat management on the public lands, as specified in the Great Divide Resource Area RMP (Sec. 202 (c) (3)(E) and Sec. $205(3)(0))$. Any road closures to implement sikes Act HMP provisions must be published in the Federal Reqister.

6. Provide for legal enforcement of sikes Act provisions and stipulations with the state agencies (Sec. 204).

The authority for the BLM and the USFS agencies to implement this act is stated below:

1. The sikes Act, as amended in 1974, Title II, P.L. 93-452 (16 U.S.C. 679 et. seq.).

2. The Sikes Act, as amended in 1978, P.L. 95-420 (16 U.S.C., 679 et. seq.)

3. The Federal Grant and Cooperative Agreement Act of 1977 (41 U.S.C. 501-509).

4. 43 CFR Part 24.

The Sikes Act of September 15, 1960, was amended on October 18, 1974, by the addition of Title II (P.L. 93-452). It was further amended in 1978 to extend its funding authority (P.L. 95-420). The basic effect of Title II was to extend the Sikes Act authority for wildlife program development from strictly Military Reservations to public lands administered by the Forest service and the BLM. At the time of its passage, the Sikes Act was viewed by BLM as an "organic act" for wildlife habitat management. It was a clear congressional charter to take positive, orderly actions on behalf of the public land's valuable wildife resources. The BLM considers Sikes Act implementation and its associated cooperation with State agencies as being of great budgetary and policy importance for overall wildlife program accomplishment.

The Federal Grant and Cooperative Agreement Act of 1977 followed the Sikes Act, being passed on February 3, 1978. This law basically established three (3) vehicles for possible award of funds for wildlife habitat improvement projects (i.e. 15 individual project Proposals in the HMP)--contracts, grants, and cooperative agreements. Any of these three (3) instruments can be used depending on the situation.

The purpose behind 43 CFR Part 24 is to clarify and support the broad authorities and responsibilities of Federal and State agencies responsible for the management of the nation's $\mathbf{f}$ ish and wildlife and to identify and promote cooperative agency management relationships which advance scientifically-based resource management programs. This is a Department of the Interior Fish and Wildlife policy. This policy is intended to reaffirm the basic role of the states in $f$ ish and resident wildlife management, especially where states have primary authority and responsibility, and to foster improved conservation of $f$ ish and wildife. In addition, in developing and implementing this policy, the Department will be furthering the manifest Congressional policy of Federal-state cooperation that pervades statutory enactments in the area of $\mathrm{figh}$ and wildife conservation. In recognition of the scope of its activities in managing hundreds of millions of acres of land within several States, the Department of the Interior \{and BLM\} will continue to seek new opportunities to foster a "good neighbor" policy with the States. These policies permit the BLM GDRA and PRRA offices to cooperate with the USFWS, USFS, and the WGFD to plan and implement projects to protect, maintain, and enhance bighorn sheep and other wildiffe population habitats within the Laramie Peak HMP Area.

\section{.31D.2 Interagency Coordination}

Interagency coordination with the Forest Service to implement Sikes Act programs 
0

0

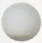


and Sikes Act-Federal Grant and Cooperative Act procedures with State agencies are conducted to the fullest extent possible. The forest involved with this HMP is the Medicine Bow National Forest (see Map 1). However, because of differing BLM-FS enabling legislation, procurement regulations, and past history of sikes Act work (see.41A), there may be occasions where each must apply its respective legislation and P.L. 95-224 to fit its own special situations.

Coordination between BLM and the FWS for Sikes Act programs is contained within an umbrella memorandum of understanding, signed May 27, 1980. The FWS supports BLM programs on public lands and will be consulted during Sikes Act actions where appropriate.

Coordination with other Federal and State agencies in developing Sikes Act wildife programs will be conducted as deemed appropriate by local gituations. Since there are fifteen (15) different Project Proposals in various locations throughout the HMP Area there will be an assortment of agencies, environmental groups, and local governments that will be consulted on individual EAs for each site-specific project. The general public will be consulted for each major EA that will be planned and implemented in the HMP Area. 
0

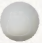

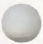


The Laramie Peak HMP is located within several jurisdictions managed by numerous local, State, and Federal agencies. The HMP Area covers approximately $2,045,278$ acres (see Table 1) and follows the WGFD Hunt Area 19 (see Maps 1 and 6 ). It must be noted that in calculating the total land acreage for the HMP Area, there are 18 full and 15 partial quads that are not included in Table 1 . An approximation of the missing data (acreage) from these quads has been calculated for the total acreage. The WGFD Hunt Area 19 was utilized as the boundary for this HMP to simplify management capabilities and strategies.

Significant portions of bighorn sheep populations occupy lands within the Douglas Ranger District of the Medicine Bow National Forest, administered by the USFS under the Land and Regource Management Plan. Medicine Bow National Forest and Thunder Basin National Grassland (see.31C, .31D). The BLM public lands in Natrona, Converse, and platte Counties that are in the HMP Area are currently being administered by the Platte River Resource Area, Casper, Wyoming under the Platte River Resource Area RMP/EIS, signed July 1985. The BLM public lands in Albany and Carbon Counties in the HMP Area are administered by the Great Divide Resource Area, Rawlins, Wyoming, under the Great Divide Resource Area RMP/EIS, signed November 1990. Both RMPs were prepared under the authority and regulations of the Federal Land Policy and Management Act of 1976 (FLPMA) (90 Stat. 2766,43 U.S.C. 1737 ). An environmental impact statement (EIS) was prepared for these plans in compliance with the National Environmental Policy Act of 1969 (NEPA) (42 U.S.C. 4321 et seq.). " The WGFD administers the wildlife within the HMP Area under A Strategic Plan for the Comprehensive Management of Wildlife in Wyoming (aee Appendix XI).

Table 1 depicts the land status of the Laramie Peak HMP Area showing BLM, USFS, State, and private land surface/mineral ownership and status. Map 1, located on page 2, displays these land ownership patterns for surface areas. It should be noted that there are some quads missing (at this point the acreage in these quads has not been calculated) in Table 1, which accounts for the difference in the total land acreage. In addition, the ownership acreage may change over time depending on land transfer events in the future.

1 These documents state that site-specific management actions will be implemented in HMP Areas and cooperative management areas to improve wildife habitat. 
0

0

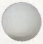


TABLE 1

Land statua/Adminietrative Acreage Summation

\begin{tabular}{|c|c|c|c|}
\hline Omerehip & Area & Frequency & Percent \\
\hline USPS Surface*/Minerals & 154104.66 & 167 & 7.59 \\
\hline BLM Surface/Minerals & 349648.62 & 776 & 17.23 \\
\hline $\begin{array}{r}\text { USPs Surface/Private } \\
\text { Minerala }\end{array}$ & 163.57 & 1 & 0.01 \\
\hline $\begin{array}{r}\text { UsFs Surface/State } \\
\text { Minerala }\end{array}$ & 1610.65 & 3 & 0.08 \\
\hline $\begin{array}{r}\text { BLM Surface/State } \\
\text { Minerals }\end{array}$ & 798.51 & 10 & 0.04 \\
\hline $\begin{array}{l}\text { Private Surface/ No agency } \\
\text { with minerals } \\
\text { juriadiction - } \\
\text { Pederal } \\
\text { subeurface } \\
\text { split eatate }\end{array}$ & 576380.89 & 1147 & 28.39 \\
\hline Private Surface/Private Minerala & 706214.33 & 1252 & 34.8 \\
\hline Open water & 12749.42 & 24 & 0.63 \\
\hline $\begin{array}{c}\text { State Surface/Federal-Minerala } \\
\text { Split estate }\end{array}$ & 33675.94 & 117 & 1.66 \\
\hline state Surface/State Minerals & 193912.34 & 511 & 9.56 \\
\hline TOTAL & $2029258.8+$ & 4008 & 99.99 \\
\hline
\end{tabular}

- Surface land

+ There are missing quads (18 full/15 partial) from the total land acreage. Calculations using information from these guads changes the total acreage to approximately 2,045,278 acres for the HMP Area. The map below depicts the where the miseing guads are located.

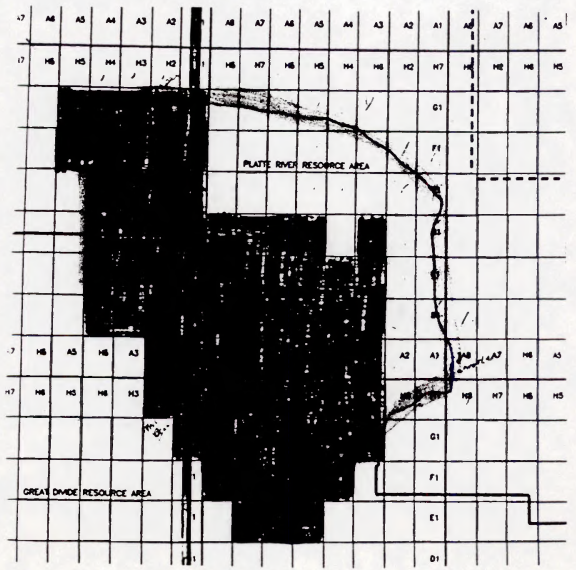


0

.

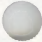


The main objective of the Laramie Peak HMP is to maintain, restore, improve and enhance habitat conditions for bighorn sheep. The goal will be attained through cooperative efforts between the USFS, BLM, WGFD, ranchers, environmental groups and the general public. The HMP goal will be met by completing several objectives through a diversity of planned actions. The planned actions inc: te fifteen (15) individual site-specific project areas within the HMP bour $y$ within the next 10-15 years. Each plan will be planned, executed and monito: $d$ using an Environmental Assessment (EA), under the authority of the NEPA process. The strategic plans within this HMP are predicted to meet the above objective by the year 2010.

The objectives for this plan are to increase the bighorn sheep population from 173 sheep (1993) to 500 sheep by the year 2009-2010, by improving and enhancing the quantity and quality of open, secure foraging areas (approximately $9,000+$ acres), adjacent to water and escape cover, in site-specific habitat areas (15 total): Due to the vastness of this area, along with the dynamics of bighorn sheep in general, these objectives will probably take the full 10-15 years to complete. As in most cases, when the habitats for a large ungulate such as bighorn sheep are enhanced, then other wildlife species benefit as well. The planned actions that will be used to complete the objectives include, but are not imited to, prescribed burns, small commercial logging practices, firewood sales, assorted fence modifications, diverse riparian improvement projects (in-stream structures, fence modifications, vegetation plantings), and possible reservoir development. As these planned actions are executed, other factors that will benefit society as a whole, such as land exchanges, acquisition of legal public access, improved hunter success rates and distribution, and recreational opportunities, may also be feasible.

Table 2 depicts a Habitat Management Plan Progress Report that will be used in the Objectives, Planned Actions, and Evaluation/Monitoring segments of the Laramie Peak HMP. Since this table is used in three (3) different portions of the HMP, it is advisable to check back to Table 2 for completion dates on specific actions.

$$
\text { * put a Rentence in not restricting to sutes. }
$$


0

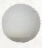

0 
TABLE 2 HABITAT MANAGEMENT PLAN PROGREBS RBPORT

\begin{tabular}{|c|c|c|c|c|c|}
\hline OBJECTIVES & $\begin{array}{c}\text { DATE } \\
\text { COMPLETED }\end{array}$ & PLANNED ACTIONS & $\begin{array}{c}\text { DATE } \\
\text { COMPLETED }\end{array}$ & EVALUATION/MONITORING & $\begin{array}{c}\text { DATE } \\
\text { COMPLETED }\end{array}$ \\
\hline $\begin{array}{l}\text { Laraie Peak Hop } \\
\text { 1. Improve the } \\
\text { distribution of } \\
\text { bighorn sheep } \\
\text { populations and } \\
\text { associated genet1c } \\
\text { diversity by } \\
\text { increasing the herd } \\
\text { numbers from } 173 \\
\text { sheep (1993) to } 500 \\
\text { sheep (2010). } \\
\text { Identify, protect, } \\
\text { andenhance bighorn } \\
\text { sheep habitat; } \\
\text { improve/increase } \\
\text { quantity and quality } \\
\text { of vegetation/forage } \\
\text { areas by } \\
\text { approximately } 9,000+ \\
\text { acres. } \\
\text { 3. Pursuit of land } \\
\text { exchanges/legal } \\
\text { public access, } \\
\text { improve hunter } \\
\text { success } \\
\text { rates/distribution, } \\
\text { improve } \\
\text { recreational uses. }\end{array}$ & & $\begin{array}{l}\text { Iaramie Peak Hop - ceneral } \\
\text { Prescribed burns; } \\
\text { Small commercial logging; } \\
\text { Firewood sales for habitat } \\
\text { improvement and diversity. } \\
\text { Fence modifications for } \\
\text { wildlife movements. } \\
\text { Aquatic/wetland improvement } \\
\text { using fence modifications, } \\
\text { update Amps, in-stream } \\
\text { structures. } \\
\text { Riparian improvement: } \\
\text { fencing/in-stream } \\
\text { structures/vegetation } \\
\text { plantings. } \\
\text { water } \\
\text { feeoxvir development: } \\
\text { waterfowl nesting } \\
\text { structures. } \\
\text { Guzelers } \\
\text { Spring development }\end{array}$ & 1 & $\begin{array}{l}\text { INVENTORIEs: } \\
\text { Bighorn sheep habitat } \\
\text { requirements: } \\
\text { (1IH) Forage } \\
\text { quantity/quality } \\
\text { (winter, opring, } \\
\text { vumer range)- } \\
\text { proximity to escape } \\
\text { terrain; } \\
\text { (2IH) Water sources near } \\
\text { escape terrain; } \\
\text { (3IH) Salt/mineral licks; } \\
\text { (4IH) Visibilty } \\
\text { quantity/quality- } \\
\text { vegetation } \\
\text { types/tree, shrub crown } \\
\text { cover; }\end{array}$ & \\
\hline
\end{tabular}

3. Liut achedule evaluation/monitoring study(s) planned to evaluate accompliahments. 
0

0

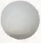


TABLE 2 HABITAT MANAGEMENT PLAN PROGRESB REPORT

\begin{tabular}{|c|c|c|c|c|c|}
\hline ORECTIVES & $\begin{array}{c}\text { DATE } \\
\text { COMPLETED }\end{array}$ & PLANNED ACTIONS & $\begin{array}{c}\text { DATE } \\
\text { COMPLETED }\end{array}$ & EVALUATION/MONITORING & $\begin{array}{c}\text { DATE } \\
\text { COMPLETED }\end{array}$ \\
\hline $\begin{array}{l}\text { 4. Facilitate habitat } \\
\text { manipulation } \\
\text { projects through } \\
\text { vegetation } \\
\text { treatments, } \\
\text { prescribed burns, } \\
\text { firewood ales, } \\
\text { small commercial } \\
\text { logging operations. }\end{array}$ & & & & $\begin{array}{l}\text { Bighorn sheep range } \\
\text { assessments: } \\
\text { (IIR) Abundance of steep } \\
\text { escape terrain; } \\
\text { (2IR) Abundance of } \\
\text { vegetation types that } \\
\text { are low growing/open } \\
\text { and known to provide } \\
\text { oheep forage-near } \\
\text { escape terrain; } \\
\text { (3IR) Abundance of southerly } \\
\text { aspects; } \\
\text { (4IR) Annual precipitation } \\
\text { and presence of } \\
\text { reliable water } \\
\text { sources; } \\
\text { and other human } \\
\text { (5IR) } \\
\text { activities/development } \\
\text { that would threaten } \\
\text { sheep and gheep } \\
\text { habitat. }\end{array}$ & \\
\hline
\end{tabular}

INSTRUCTIONS

1. Lis specific HMP objectives as developed from RMP/MFP planning documents or as otherwise approved.

2. Lis apecific planned actions to be initiated to meet each apecific objective.

3. List achedule evaluation/monitoring atudy $(s)$ planned to ovaluate accompliahments.

4. Enter completion date for ench objective, action, or evaluation/monitoring atudy as accompliahed. 
.

O

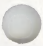


TABLE 2 HABITAT MANAGEMENT PLAN PROGREgs REPORT

\begin{tabular}{|c|c|c|c|c|c|}
\hline ORJECTIVES & $\begin{array}{c}\text { DATE } \\
\text { COMPLETED }\end{array}$ & PLANNED ACTIONS & $\begin{array}{c}\text { DATE } \\
\text { COMPLETED }\end{array}$ & EVALUATION/MONITORING & $\begin{array}{l}\text { DATE } \\
\text { COMPLETED }\end{array}$ \\
\hline$\underset{\omega}{\omega}$ & & & & 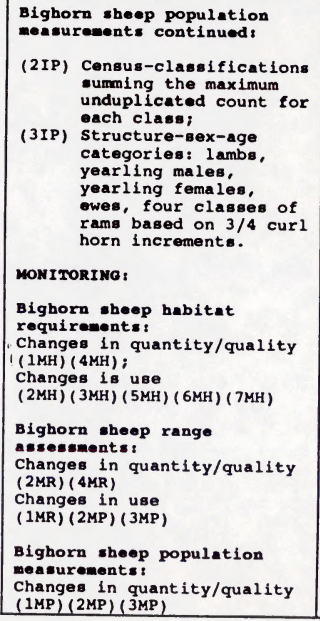 & \\
\hline
\end{tabular}

INSTRUCTIONS

1. List epecific HMP objectives at developed from RMP/MFP plenning documents or at otherwino approved.

2. Liat apecific planned action to be initiated to meet each apecific objective.

3. Liat echedule evaluation/monitoring study(o) planned to ovaluate accompliahments.

4. Enter completion date for each objective, action, or evaluation/monitoring atudy a accompliahed. 
0

0

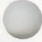


HABITAT MANAGEMENT PLAN PROGRESB REPORT

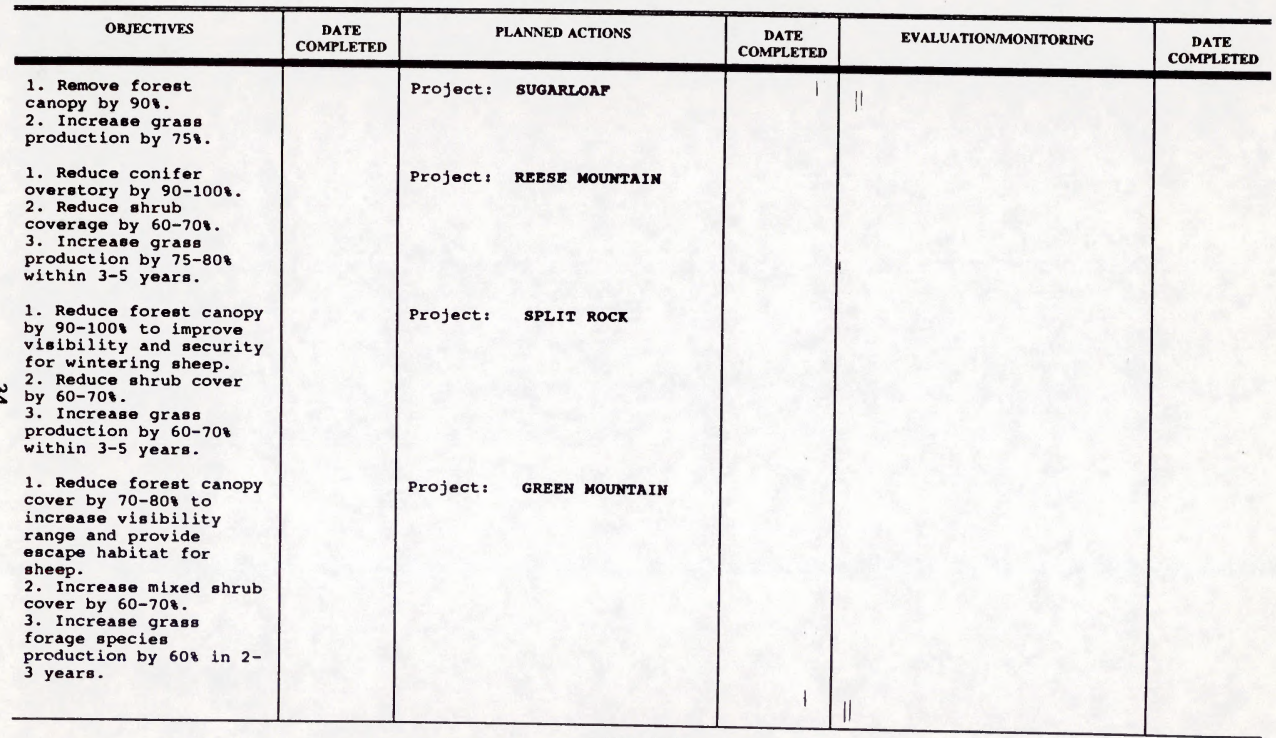

1. List epecific HMP objectives as developed from RMP/MFP planning documents or as otherwive approved.

2. Lis apecific planned actiona to be initiated to meet each specific objective.

3. Lise schedule evaluation/monitoring study(0) planned to evaluate accompliahments.

4. Enter completion date for each objective, action, or evaluation/monitoring atudy as accompliabed. 
HABITAT MANAGEMENT PLAN PROGRESB REPORT

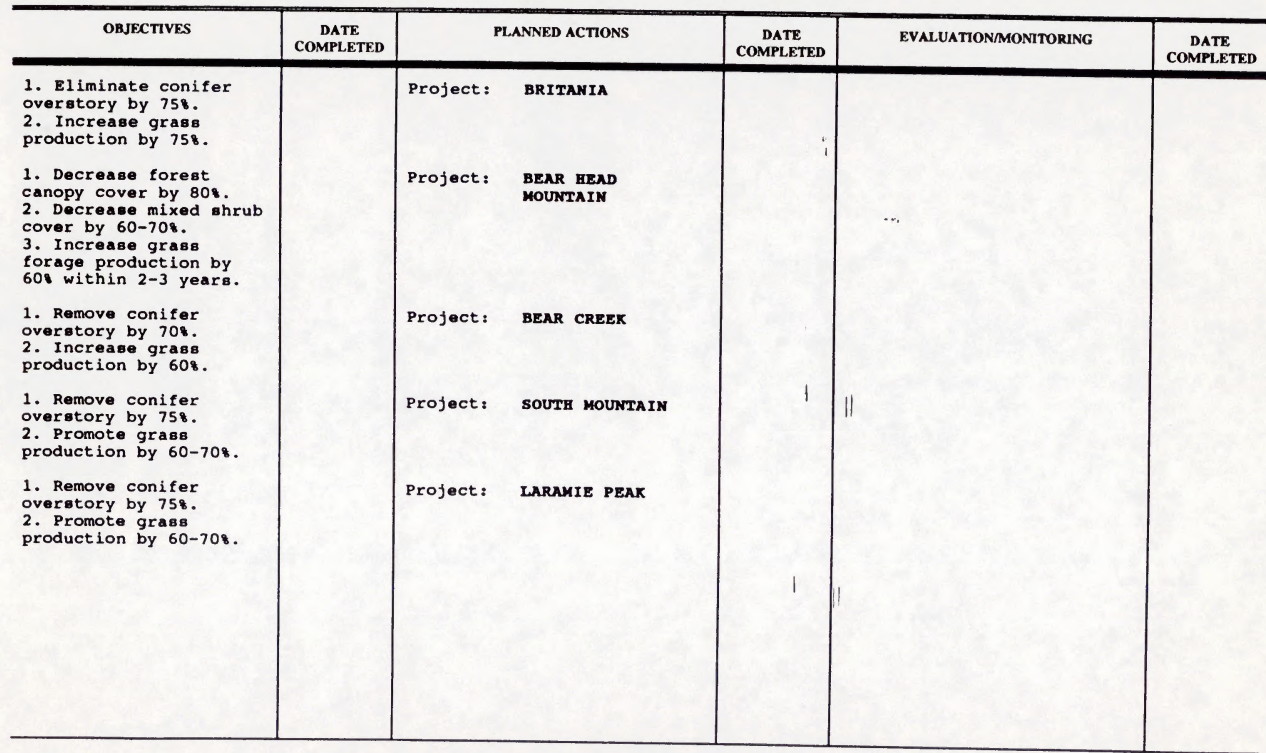

3. List achedule evaluation/monitoring atudy(o) planned to ovaluate accompliahments.

4. Enter completion date for each objective, action, or evaluation/monitoring atudy a accompliahed. 
0

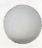

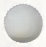


HABITAT MANAGEMENT PLAN PROGRESB REPORT

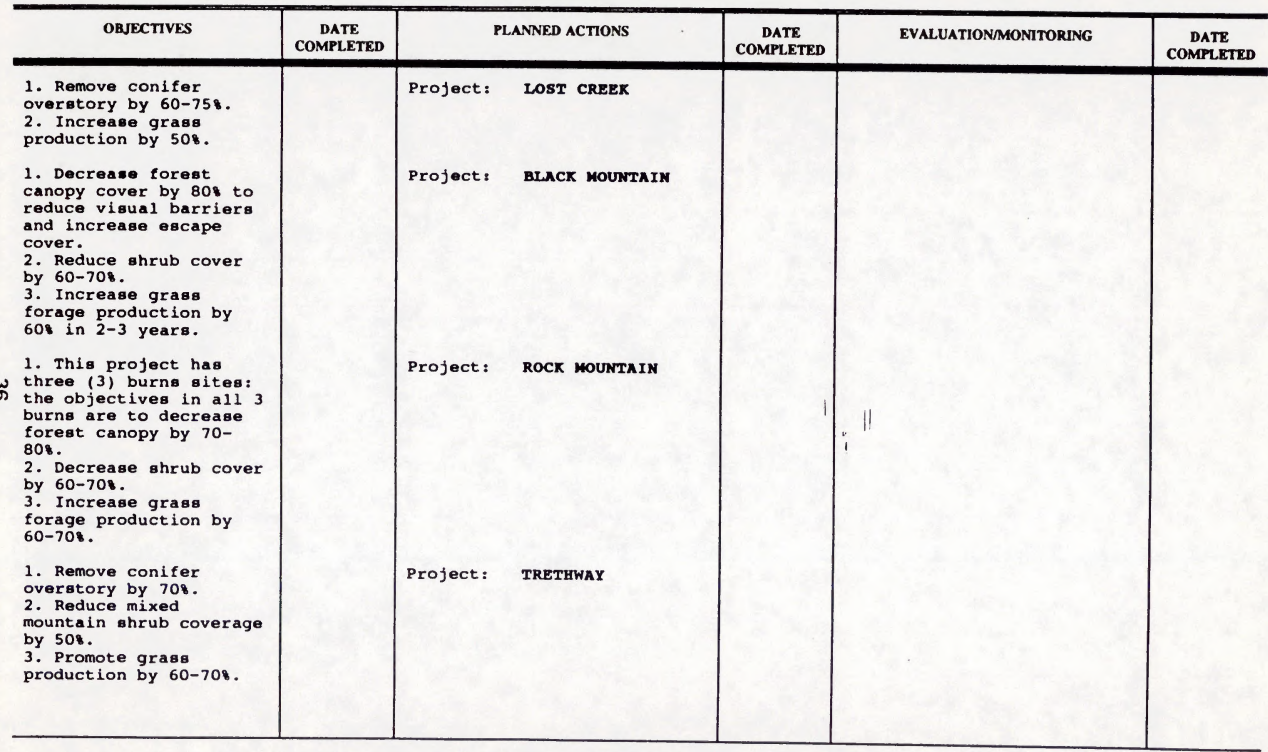

1. Lixt apecific HMP objectives at developed from RMPMFP planning documents or at otherwino approved.

2. Lia specific planned actions to be initiated to meet each apecific objective.

3. Liat achedule evaluation/monitoring atudy(s) planned to evaluate accompliathments.

4. Enter completion date for each objective, action, or evaluation/monitoring study at accompliahed. 
0

0 
HABITAT MANAGEMENT PLAN PROGRESS REPORT

\begin{tabular}{|c|c|c|c|c|c|}
\hline OBJECTIVES & $\begin{array}{c}\text { DATE } \\
\text { COMPLETED }\end{array}$ & PLANNED ACTIONS & $\begin{array}{c}\text { DATE } \\
\text { COMPLETED }\end{array}$ & EVALUATION/MONITORING & $\begin{array}{c}\text { DATE } \\
\text { COMPLETED }\end{array}$ \\
\hline $\begin{array}{l}\text { 1. Remove ponderosa } \\
\text { pine overstory by } 758 \text {. } \\
2 \text {. Increase grass } \\
\text { production by } 708 \text {. } \\
\text { 1. Remove conifer } \\
\text { overstory by } 75-858 \text {. } \\
\text { 2. Increase gras8 } \\
\text { production by } 758 \text {. }\end{array}$ & & $\begin{array}{l}\text { Project: } \text { sawToOTH } \\
\text { Project: ALBANY }\end{array}$ & & & \\
\hline \multicolumn{6}{|c|}{$\begin{array}{l}\text { INSTRUCTIONS } \\
\text { ed from RMP/MFP planning documenta or as otherwise approved. } \\
\text { ed to meet each specific objective. } \\
\text { (s) planned to evaluate accomplishments. } \\
\text { action, or evaluation/monitoring study as accomplished. }\end{array}$} \\
\hline
\end{tabular}

* Other sites as identified, planned actions, evaluation and monitoring programs will be permitted if required in the future. 
0

0

0 


\section{. 34 Planned Actions}

This section of the HMP provides detailed management prescriptions for achieving objectives described under section .33 of the Laramie Peak HMP. As stated previously within this document, the major goal of the HMP Area at this time is to improve the distribution of bighorn sheep populations and associated genetic diversity by increasing and improving the quantity and quality of open, secure foraging areas (preferably adjacent to water and escape cover) in site-specific habitat areas. The objectives are to increase the herd numbers to 500 sheep by improving 9,000+ acres of habiats by the year 2010 . There are fifteen (15) areas of concern (proposed project sites) that management objectives, when completed, will accomplish the overall goal of improving bighorn sheep populations in the Laramie Range. Table 2 has a list of objectives and planned actions that can be used for each site-specific area; at this time the exact area of concentration for the site-specific EA has not been selected (this will be done at the team level), therefore, any planned actions, inventory and monitoring mechanisms will be written in Table 2 as each EA is prepared. The completion of these objectives should indirectly maintain, protect, and enhance habitats within the HMP Area for a diversity of other wildife species. Additional factors that may accrue over the life of this plan include the pursuit of land exchanges, legal public access, improved hunter success rates, other recreational uses, and the public use of further resources (e.g. firewood sales, small commercial logging operations).

\section{.34A Description of Actions}

\section{.34A.1 Existing and Planned Improvements to Summarize Actions}

The general management goal (planned improvements) that this HMP will permit utilizing an ecosystem approach towards improving the public lands is to identify and protect habitat sites, as well as special and unique features that are essential for the viability and sustainability of wildife populations, specifically bighorn sheep. The diversity of site specific projects that will result from management actions within this plan will provide habitat quality and quantity (food, cover, space, and water) that will be adequate to support a natural diversity of wildlife and fisheries. Additional species that will benefit from an ecosystem approach include big game species, upland game species, waterfowl, non-game species, game fish, neotropical migratory birds, amphibians, reptiles, threatened and endangered species, sensitive species and species of special concern (Appendix III).

Currently, there are some existing projects that are proposed in the Laramie Peak HMP Area. A prescribed burn, BLM Environmental Assessment WY-037-EA0-038 (see Appendix $(x)$ which has been scheduled for the Split Rock area-for the Laramie Peak bighorn sheep has been extremely difficult to execute for the past several field seasons due to the relatively strict windows (burn operation-restrictions). This burn is located in the south and central portions of T. $24 \mathrm{~N}$., R. 71 W., Section 31 and T. $24 \mathrm{~N} .$, R. 72 W., sections 25 and 36 . The proposed action is to prescribe burn sagebrush/grass in the spring and felled timber in the fall within a 400 acre perimeter area as soon as the windows open.

Since the prescribed burns are difficult to complete, an additional project has been designed for the above area to fell timber manually by the BLM fire crews in July, August or September. This project will and has mitigated restricted travel conditions of enclosed corridors that the sheep attempt to utilize as transportation routes from lambing/nursery grounds to forage areas. Approximately 400 trees were felled in the summer of 1993 by the BLM fire crews. There are more areas within the split Rock prescribed burn area that need additional trees felled. At this point in time the crews are logistically prepared to complete the timber cutting project, however, they are fire personnel and the 1994 fire season has been extremely busy, therefore the project has been put on hold.

A BLM proposed action to conduct a salvage harvesting operation on about 220 acres of beetle-killed forest in the Pine Mountain area (R. 71 w., T. 24 N., 
0

0

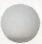


Secs. 19 and 30 ; and R. 72 W., T. 24 N., Sec. 25) is in the draft stage at this time. The objectives of this proposal are to improve sheep movement through existing dense corridors, improve vegetative landscape conditions to facilitate future prescribed burning for forest and wildlife objectives, reduce fuel loadings, and to recover a natural resource for human use. The proposed action would be implemented by the issuance of a timber sale contract with applicable stipulations (see .37A). This proposed action is consistent with the Great Divide Resource Management Plan (RMP), approved Nov. 8, 1990.

Proposed activities for the HMP include the projects in the following habitat areas (see map 11):

\author{
Sugarloaf \\ Reese Mountain \\ Split Rock \\ Britannia \\ Green Mountain \\ Bear Head Mountain \\ Bear Creek \\ South Mountain \\ Laramie Peak \\ Albany Peak \\ Lost Creek \\ Black Mountain \\ Rock Mountain \\ Trethway \\ sawtooth
}

.34A.2 Methods and Planned Actions Required to Achieve the HMP objectives

The objectives will be accomplished through a diversity of site-specific projects that are planned in a logical sequence with a priority detail. The planned actions include the following types of actions: direct actions -- these include activities, costs and manpower needs by project to meet specified wildlife objectives; supporting or facilitating actions (e.g. roads, fire protection, land exchange) to permit the direct action to be implemented, including cost and manpower needs for the appropriate sub-activity involved; and mitigation and/or protection actions (see Appendix VIII).

The direct actions are based on specific criterion for each project which is based upon the following factors:

I. SIGNIFICANCE

A. Potential value to sheep:
1. Winter range
2. Summer range
3. Reproductive/parturition range
4. Travel corridors

B. Contribution to existing local habitat.

c. Contribution to sheep distribution over the HMP Area and the WGFD Hunt Areas.

D. Contribution to sheep movement/interchange.

I I EFFECTIVENESS

A. Overall low relative cost per effort.

B. High return of resource values per unit effort. 


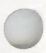

0

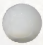


C. Successful completion relative to habitat development for future projects and/or associated program elements.

III. FEASIBILITY

A. Practicality of implementation.

1. Topography

2. Forest cover relative to treatment area site

3. Road/land access

At this point in time, there are fifteen (15) different treatment sites within the HMP Area that have unique objectives, but an overall common goal to improve habitat for bighorn heep. Management of these sites, utilizing the significance, effectiveness and feasibility tools, will be based upon established priorities that will be mutually agreed upon by the interagency team implementing the projects. Site-specific Environmental Assessments (EAs) will be completed for each project area (treatment site) before any activities occur. Listed below in Table 3 are the different treatment site locations and treatment site ratings f of members of the WGFD, BLM, USFS, other team players, and the general public:

Table 3

Treatment site Rating for Project Activities

Location

Sugarloaf

Reese Mountain

Split Rock

Britannia

Green Mounta in

Bear Head Mt.

Bear Creek

South Mountain

Laramie Peak

Albany Peak

Lost Creek

Black Mountain

Rock Mountain

Trethway

Sawtooth

\section{Significance}

3
2
2
2
1
1
1
2
1
1
2
1
1
3
1

3
2
2
2
2
2
1
3
3
1
3
2
1
2
2

$1-2=$ High
$2=$ Moderate
$3=$ Low

Criteria Summation

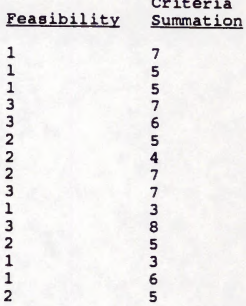

Score $3-4=$ Priority 1
Score $5-6=$ Priority 2
Score $7-8=$ Priority 3

The lower the total scores are using this table then the higher the priority is for the implementation of the project. Following is a brief discussion that describes the priorities that will be utilized when determining which projects to implement initially.

Priority 1 (fits one or more of the following conditions)

(a) Most feasible for management based on accessibility, landownership patterns and ease of treatment.

(b) Located in potentially high-value sheep habitat where the benefits of 
0

0

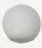


treatment will best meet population objectives.

(c) Conflicts with other landowners and resource values are relatively insignificant.

(d) Areas of greatest need if objectives are to be met within established time frames.

Priority 2 (fits one or more of the following conditions)

(a) Vegetative manipulation would be more difficult than Priority 1 due to land ownership patterns or accessibility.

(b) Located in potentially high-value sheep habitat where the benefits will help meet objectives, but the returns will be slightly less than

Priority 1 areas.

(c) Conflicts with other landowners and resource values may require mitigation.

(d) Areas in need of habitat manipulation if the objectives are to be met within established time frames.

Priority 3 (fits one or more of the following conditions)

(a) Management and habitat manipulation would be difficult under exigting landownership patterns and access or the size of the proposed treatment area makes specific treatment expensive.

(b) Located in potentially high-value sheep habitat where treatment will help meet objectives.

(c) Conflicts with other resources may require mitigating actions to reduce the significance to other resources.

(d) Treatment of Priority 3 areas is important to fully meet objectives, but treatment through prescribed fire is unlikely due to high risk, high value or difficult land patterns.

The treatment areas are based upon desired habitat types to improve bighorn sheep survival as a population. Habitat types are ranked based upon wildife communities combined with the availability of each type (see Table 4 ). Utilizing the habitat types in a priority ranking system, the different activities implemented for bighorn sheep can be decided upon based on desired vegetation complexes. 
0

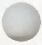

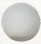


TARLE 4

RANKING OF STANDARD BABITAT TYPES

\begin{tabular}{|c|c|c|}
\hline $\begin{array}{c}\text { EIGE } \\
\text { PRIORITY }\end{array}$ & $\begin{array}{l}\text { MODERATE } \\
\text { PRIORITY }\end{array}$ & $\begin{array}{l}\text { LOW } \\
\text { PRIORITY }\end{array}$ \\
\hline $\begin{array}{l}\text { Open aquatic } \\
\text { grasslands } \\
\text { Riparian grassland } \\
\text { steppe } \\
\text { Willow-waterbirch riparian } \\
\text { Aspen riparian } \\
\text { Cottonwood riparian } \\
\text { dunes } \\
\text { Mountain shrub } \\
\text { meadows } \\
\text { Utah juniper } \\
\text { Quaking aspen } \\
\text { Aspen conifer } \\
\text { Ponderosa pine/Douglas-fir } \\
\text { Platte Valiey rockland } \\
\text { Laramie Peak rockland } \\
\text { Wet forested meadow }\end{array}$ & $\begin{array}{l}\text { Greasewood-sagewood riparian } \\
\text { Big sagebrush-rabbitbrush } \\
\text { Bitterbrush } \\
\text { Sagebrush-mixed grass } \\
\text { Silver sagebrush steppe } \\
\text { Lodgepole pine } \\
\text { Limber pine } \\
\text { Early successional conifer } \\
\text { Rockland } \\
\text { Saline sub-irrigated grassland }\end{array}$ & $\begin{array}{l}\text { Short } \\
\text { Saltbush } \\
\text { Greasewood } \\
\text { Badland } \\
\text { True sand } \\
\text { Upland }\end{array}$ \\
\hline
\end{tabular}

NOTE: Ranking is based on the wildlife communities (total species, number of breeders, number of rare species) combined with the availability of each type.

1 High priority habitats are those that require intensivemanagement actions (data collection, enhancement, protection) to maintain their productivity as diverse wildlife communities; moderate-priority habitats are those that require less intensive management to maintain their productivity as wildife communities; low-priority habitats are those that can be more heavily used by conflicting resources so that the higher priority wildife habitats can be maintained.

Summarized below are the locations of the proposed habitat treatment sites (planned actions) described in a logical sequence (priority order) for implementation to achieve each objective:

\section{Proposed Habitat Improvement Areas}

\section{Priority}

1 Sugarloaf - T. 23 N., R. 71 W. (1120 acres optimum)
Section 7: $51 / 2$

section 8: $51 / 2$

Section 17: N1/2

section 18: N1/2 


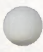

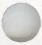

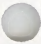




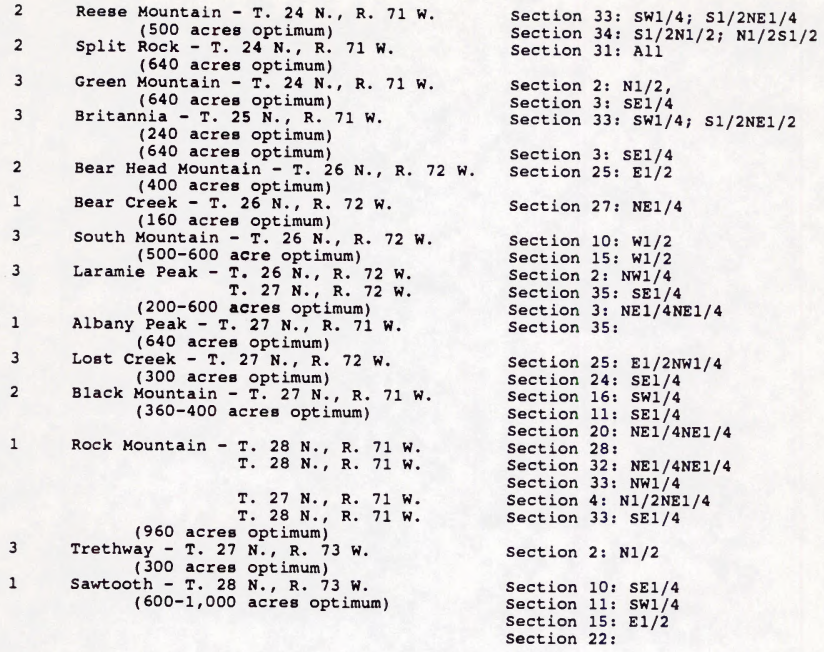

Listed below are the site-specific activities relative to location, management goals, specific objectives, size and ownership of project sites, topography, and vegetation types at the site (see Map 11). Individual EAs will be planned and imlemented on an ecosystem and interagency basis for each site.

\section{PROJECT - SUGARLOAF}

Location:

$\begin{array}{llll}\text { S2 } & \text { Section 7) } & & \\ \text { S2 } & \text { Section 8) } & & \\ \text { N2 } & \text { Section 17) } & \text { T. } 23 \text { N., R. } 71 \text { W. } \\ \text { N2 } & \text { Section 18) }\end{array}$

\section{MANAGEMENT GOALS}

1. To increase the quality/quantity of summer forage and gize of lambing areas; and

2. To provide for a usable movement corridor between the Laramie Peak Unit and the south slope of the ridge east of Sugarloaf (potential winter range). 
0

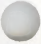

0 
SPECIFIC OBJECTIVES

1. To remove forest canopy by 90 percent.

2. To increase grass production by 75 percent.

SIZE AND OHNERSHIP

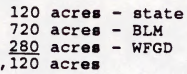

(proposed burn will encompass approximately 50 percent of the total acreage)

TOPOGRAPHY

elevation: $6400^{\prime}-7600^{\circ}$

$x$ slope: 45 percent

aspect: $N$

VEGETATION TYPES

upper slopes - ponderosa pine

lower slopes - mixed mountain foothills shrub

Additional Comments:

Potential commercial harvest areas.

\section{PROIECT - REESE MOUNTAIN}

Location:

SW $1 / 4$

$S 1 / 2 \mathrm{NE} 1 / 4$

Section 33)

Section 33)

SI/2N1/2 Section 34)

$\mathrm{N} 1 / 2 \mathrm{SI} / 2$ Section 34 )

T. 24 N., R. $71 \mathrm{~W}$.

MANAGEMENT GOALS

1. To improve winter range forage; and

2. To improve security (visibility).

SPECIFIC OBJECTIVES

1. To reduce conifer overstory by 90-100 percent.

2. To reduce shrub coverage by 60-70 percent.

3. To increase grass production by 75-808 within 3-5 years.

SIZE AND OWNERSHIP

500 acres - USFS

TOPOGRAPHY

elevation: $6400^{\circ}-7600^{\circ}$

$x$ slope: \pm 40 percent

aspect: $S \bar{B}$

VEGETATION TYPES 
0

0

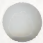




\section{PROJECT - SPLIT ROCK}

Location:

Section 31 Al1, T. 24 N., R. 71 W.

MANAGEMENT GOALS

1. To increase and improve winter range.

BURN OBJECTIVES

1. Reduce forest canopy by 90-100 percent to improve

visibility and security for wintering sheep.

2. Reduce shrub cover by 60-70 percent.

3. Increase grass production by 60-70 percent within 2-3 years.

SIZE AND OWNERSHIP

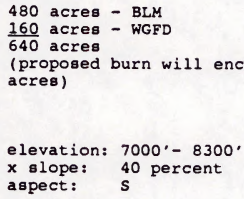

VEGETATION TYPES

Upper slopes - ponderosa pine

lower slopes - mixed shrub

Additional Comments:

\section{PROIECT -GREEN MOUNTAIN}

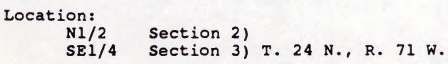

MANAGEMENT GOALS

1. To create or increase bighorn sheep habitat; and

2. To increase sheep distribution and facilitate movement. 


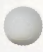

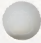

。 
1. Reduce forest canopy cover by 70-80 percent to increase visibility range thereby providing escape habitat for sheep.

2. Increase mixed shrub cover by 60-70 percent.

3. Increase grass forage species production by 60 percent in $2-3$ years.

SIZE OF OWNERSHIP

640 acres - Private (belonging to Chuck shellhorst)

TOPOGRAPHY

elevation range: $6800^{\circ}-7700^{\prime}$

average slope: 34 percent

aspect: mostly S to SE, some $E$

VEGETATION TYPES

upper slopes - mostly ponderosa pine

lower slopes - some mixed shrub ( 25 percent of area)

Additional Comments:

\section{PROIECT - BRITANIA}

Location:
SW $1 / 2$
Section 33:
T. 25 N., R. 71 W.

$\mathrm{S} 1 / 2 \mathrm{NWI} / 4$

Section 33: T. 25 N., R. 71 W.

\section{MANAGEMENT GOALS}
1. To provide for winter forage near escape cover;
2. To increase bighorn sheep distribution; and
3. To facilitate bighorn sheep movement.

SPECIFIC OBJECTIVES

1. To eliminate conifer overgtory by 75 percent.

2. To increase grass production by 75 percent.

SIZE AND OWNERSHIP

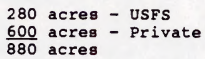

TOPOGRAPHY

$$
\begin{array}{ll}
\text { elevation range: } & 7300^{\prime}-7900^{\circ} \\
\text { x lope: } & 23 \text { percent } \\
\text { aspect: } & \mathrm{SE}
\end{array}
$$

VEGETATION TYPES

Ponderosa pine

Additional Comments:

Potential commercial harvest area. 
0

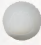

O 


\section{PROIECT - BEAR HEAD MOUNTAIN}

Location:

E1/2 Section 23

W1/2 NW $1 / 4$ Section 24 T. 26 N., R. $72 \mathrm{w}$.

MANAGEMENT GOAL

1. To increase sheep winter range; and

2. To increase sheep distribution.

SPECIFIC BURN OBJECTIVES

1. Decrease forest canopy cover by 80 percent.

2. Decrease mixed shrub cover by 60-70 percent.

3. Increase grass forage production by 60 percent within $2-3$ years.

SIZE AND OWNERSHIP

400 acres - USFS

TOPOGRAPHY

elevation range: $7200^{\prime}-8200^{\prime}$

average slope: 38 percent

aspect: SE

\section{VEGETATION TYPES}

Ponderosa pine and mixed shrubs. Varying percentages of each depending on elevation (i.e., lower elevations contain a greater percentage of shrubs than upper elevations).

Additional Comments:

\section{PROJECT - BEAR CREEK}

Location:

NE1/4 Section 27: T. 26 N., R. 72 W.

MANAGEMENT GOALS

1. To increase bighorn sheep summer range;

2. To increase bighorn sheep lambing areas; and

3. To increase bighorn sheep winter range.

SPECIFIC OBJECTIVES

1. Remove conifer overatory by $70 \%$.

2. Increase grass production by 608 .

SIZE AND OWNERSHIP

160 acres - Private

TOPOGRAPHY

elevation range: $6600^{\prime}-7300^{\circ}$

$x$ slope; $40-50$ percent 
0

0

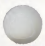


aspect: $\mathrm{SW}$ and $\mathbf{E}$

VEGETATION TYPES

Ponderosa pine woodland mixed with the mountain foothills shrubs.

Additional Comments :

\section{PROJECT - SOUTH MOUNTAIN}

Location:

W1/2 Section 10: T. 26 N., R. 72 W.

W1/2 Section 15: T. 26 N., R. 72 W.

MANAGEMENT GOALS

1. To create bighorn sheep winter range; and

2. To increase bighorn sheep distribution.

\section{SPECIFIC OBJECTIVES}

1. Remove conifer overstory by 758 .

2. Promote grass production by 60-708.

SIZE AND OWNERSHIP

500-600 acres - USFS

TOPOGRAPHY

elevation range : $7200^{\circ}-8100^{\circ}$

$x$ slope: 68 percent

aspect: $\mathrm{E}$

VEGETATION TYPES

ponderosa pine

lodgepole pine -

Additional Comments: =

\section{PROJECT - LARAMIE PEAK}

Location:

SE1/2 Section 35: T. 27 N., R. 72 W.

NE1/4NE1/4 Section 3: T. 26 N., R. 72 w.

NW1/2 Section 2: T. 26 N., R. 72 W.

MANAGEMENT GOALS

1. To create bighorn sheep summer-yearlong range.

\section{SPECIFIC OBJECTIVE}

1. Remove conifer overstory by 758 .

2. Promote grass production by 60-708. 
0

0

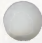


SIZE AND OWNERSHIP

$$
\text { 200-600 acres - USFS }
$$

TOPOGRAPHY

elevation range: $8700^{\prime}-9700^{\prime}$

$x$ slope: 47 percent

aspect: $\mathrm{SE}$

\section{VEGETATION TYPES}

lodgepole pine

Additional Comments:

\section{PROJECT - LOST CREEK}

Location:

NE1/4NW1/4 Section 25

SE1/4NW1/4 Section 25 T. 27 N., R. 72 W.

SE1/2 Section 24

MANAGEMENT GOALS

1. To increase bighorn sheep summer range; and

2. To create bighorn sheep lambing areas.

SPECIFIC OBJECTIVES

1. Remove conifer overatory by 60-758.

2. Increase grass production by 50 .

SIZE AND OWNERSHIP

300 acres - USFS

TOPOGRAPHY

elevation range: $7500^{\prime}-9000^{\prime}$

$x$ slope: 57 percent

aspect: $\mathrm{N}-\mathrm{E}$

VEGETATION TYPES

upper slopes - lodgepole pine
lower slopes - ponderosa pine

Additional Comments: 


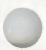

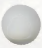

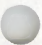




\section{PROJECT - BLACK MOUNTAIN}

Location:

SW1/4 Section 16

SE1/4 Section 19 T. 27 N., R. 71 W.

NE1/4NE1/4 Section 20

MANAGEMENT GOALS

1. To create and/or improve summer and year-round sheep range.

BURN OBJECTIVES

1. Decrease forest canopy cover by 80 percent to reduce visual barriers and increase escape cover.

2. Reduce shrub cover by 60-70 percent.

3. Increase grass forage production by 60 percent in 2-3 years.

SIZE AND OWNERSHIP

160 acres - State of Wyoming

200 acres - USFS

$\frac{200}{360}$

TOPOGRAPHY

elevation range: $7250^{\circ}-8030^{\prime}$

average slope: 59 percent

aspect: $S$ to $S E$

VEGETATION TYPES

Conifer overstory - ponderosa pine at lower elevations to lodgepole pine and spruce $f$ ir at higher elevations.

Additional Comments:

\section{PROJECT - ROCK MOUNTAIN}

( 3 separate burn areas)

Location:

Unit No. 1 - Section 28 T. 28 N., R. 71 w.

Unit No. 2 - NENE Section 32

NW1/4 Section 33 T. 28 N., R. 71 w.

Unit No. 3 SE1/4 Section 33 T. 28 N., R. 71 W.

NENW Section 4

NWNE Section 4 T. 27 N., R. 71 W.

NENE Section 4

MANAGEMENT GOALS

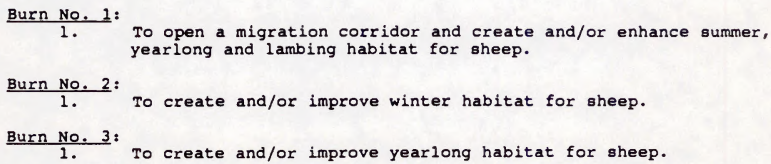

Burn No. 2:

1. To create and/or improve winter habitat for sheep.

$\frac{\text { Burn No. 3: }}{1 .}$ To create and/or improve yearlong habitat for sheep. 
0

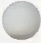

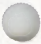


Objectives in all three burns are to decrease forest canopy by 70-80 percent, decrease shrub cover by $60-70$ percent and increase grass forage production by
$60-70$ percent.

\section{SIZE AND OWNERSHIP}

Burn No. 1

40 acres - Private

600 acres - USFS

Burn No. 2

200 acres - USFS

Burn No. 3

120 acreg - USFS

TOPOGRAPHY

Burn No. 1

elevation range: $5900^{\circ}-7200^{\circ}$

average slope: 30 percent

aspect: $\mathrm{N}$

Burn No. 2

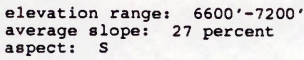

Burn No. 3

elevation range: $6700^{\circ}-7100^{\prime}$

average slope: 30 percent

aspect: Ridgetop - E, W and $S$ aspects

\section{VEGETATION TYPES}

All three burns are varying mixtures of ponderosa pine and mixed shrub.

Additional Comments :

\section{PROJECT - TRETHWAY}

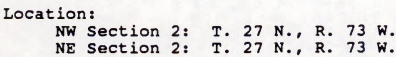

MANAGEMENT GOALS

1. To enhance bighorn sheep summer range.

\section{SPECIFIC OBJECTIVES}

1. Remove conifer overstory by 708 . 


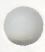

0

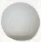


2. Reduce mixed mountain shrub coverage by 508 .

3. Promote grass production by $60-708$.

SIZE AND OWNERSHIP

300 acres - USFS

TOPOGRAPHY

elevation range: $7700^{\circ}-8200$ '

$x$ slope: 23 percent

aspect: $\mathrm{SE}$

VEGETATION TYPE

mixed ponderosa woodland/mixed mountain foothills shrubs

Additional Comments:

\section{PROJECT - SAWTOOTH}

Location:

$\begin{array}{ll} & \text { Section } 22 \\ \text { E } & \text { Section } 15 \\ \text { SE } & \text { Section } 10 \\ \text { SW } & \text { Section } 11\end{array}$

T. $28 \mathrm{~N}$, R. 73 พ.

MANAGEMENT GOALS

1. To increase bighorn sheep summer range; and

2. To create bighorn sheep lambing areas.

\section{SPECIFIC OBJECTIVES}

1. Remove ponderosa pine overstory by 75 percent.

2. Increase grass production by 70 percent.

SIZE AND OWNERSHIP

600-1,000 acres - USFS

TOPOGRAPHY

elevation range: $6600,-8000^{\prime}$

$x$ slope: $20-25$ percent

aspect: $\mathrm{N} / \mathrm{NW} / \mathrm{E}$

VEGETATION TYPES

1. ponderosa pine forest

2. lodgepole pine forest

Additional Comments: 
0

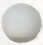

م 


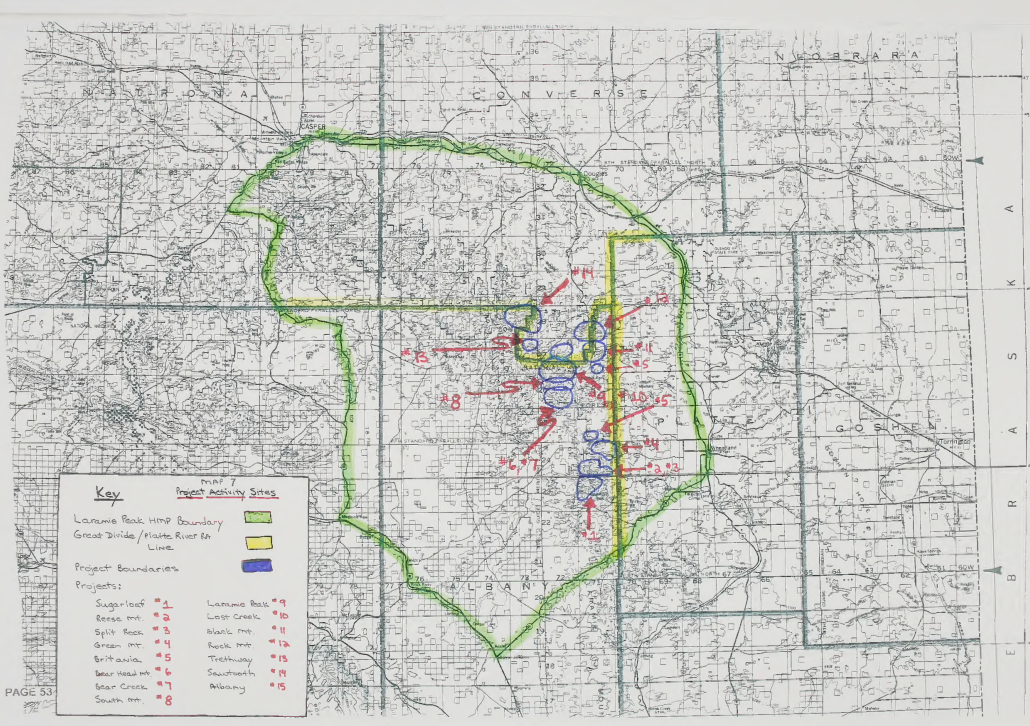





\section{$.34 \mathrm{~A} .5$ Visitor Management in the HMP Area}

The majority of visitors that will enter the HMP Area will be recreationists and hunters (see $.37 \mathrm{C}$ ). The recreation mana nent decisions in the GDRA RMP and the PRRA RMP meet legal requirements for the healtn and safety of visitors and mitigate conflicts with other uses. Visitor management in the HMP Area for the BLM includes emergency services, information and interpretation services, and visitor and resource protection.

\section{A.5.a Emergency Services}

The GDRA and PRRA Fire personnel respond to all emergency fire, first-aid and other emergency services that may occur in the HMP Area. Map 8 illustrates the locations of specialized emergency services for the area. Local and State services are also utilized if necessary. The BLM office has a policy that all personnel working in the HMP Area must report to the designated office two (2) times per day to ensure that the people are safe and accounted for.

\section{.34A.5.b Information and Interpretation Services}

This segment of the HMP describes any management actions related to information and interpretation that have been and are to be taken to resolve identified issues (e.g. safety, recreation opportunities) and to maximize the effectiveness of other kinds of management actions (e.g. off-road vehicle designation, visitor protection). At this time, there are not any recreation site development plans for this HMP Area (see Map $9)$ in the GDRA. In addition, there are not any special recreation management areas as well (see Map 10). There are general management objectives in the GDRA RMP that are stated to ensure the continued availability of outdoor recreational opportunities. There are opportunities for potential recreation and information interpretive sites (e.g. Watchable Wildlife signs) to be proposed for the area in the future depending upon availability of funding and the overali direction of ecosystem management in relation to public uses of valuable resources. Any recreational activities that do occur within the HMP Area must adhere to all applicable local, State, and Federal laws, rules and regulations as stated in the GDRA RMP and the PRRA RMP.

Consistent with the Wyoming BLM access policy, the BLM will pursue opportunities to acquire or maintain legal access in portions of the HMP Area (see Map 11). This will be administered in a coordinated effort between the BLM, USFS, WGFD, and interested applicable parties. Additional access needs will be considered as they are identified or as opportunities arise.

At this time there are not any off-road vehicle (ORV) plans that are prepared for the HMP Area in which visitor management applications can be applied (see Map 12). If a site-specific EA requires an ORV implementation plan, or possible permenant/seasonal road closures, then it will be coordinated with owners of adjacent properties, interested individuals, organizations, and other agencies. In the general planning area, with some exceptions, the area is open to use of motorized over-the-snow vehicles, provided that they do not advergely affect the wildife or vegetation. other motorized vehicle use in the GDRA and Laramie Peak HMP Area is 1 imited to existing roads and trails. There are not any exceptions to this rule in the HMp Area at this time, however, they may be determined as necessary if warrented and will be acted upon after public disclosure and consent.

\section{.34A.5.C Visitor and Resource Protection}

The GDRA RMP does identify managemnet actions related to visitor and resource protection that have been and are to be taken to resolve identified isgues such as hazards and protection of sensitive resources. The process of protection that occurs utilizes Standard Mitigation Guidelines (see Appendix VIII) that are integrated into the RMP process and will therefore be integrated into the site-specific environmental analysis (EA) process for each habitat project area (15 total) in the HMP. The application of the standard mitigation guidelines to all surface and other human presence disturbance activities concerning the BLM-administered public lands and 


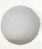

0

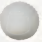


Map 8 
O

O

, 


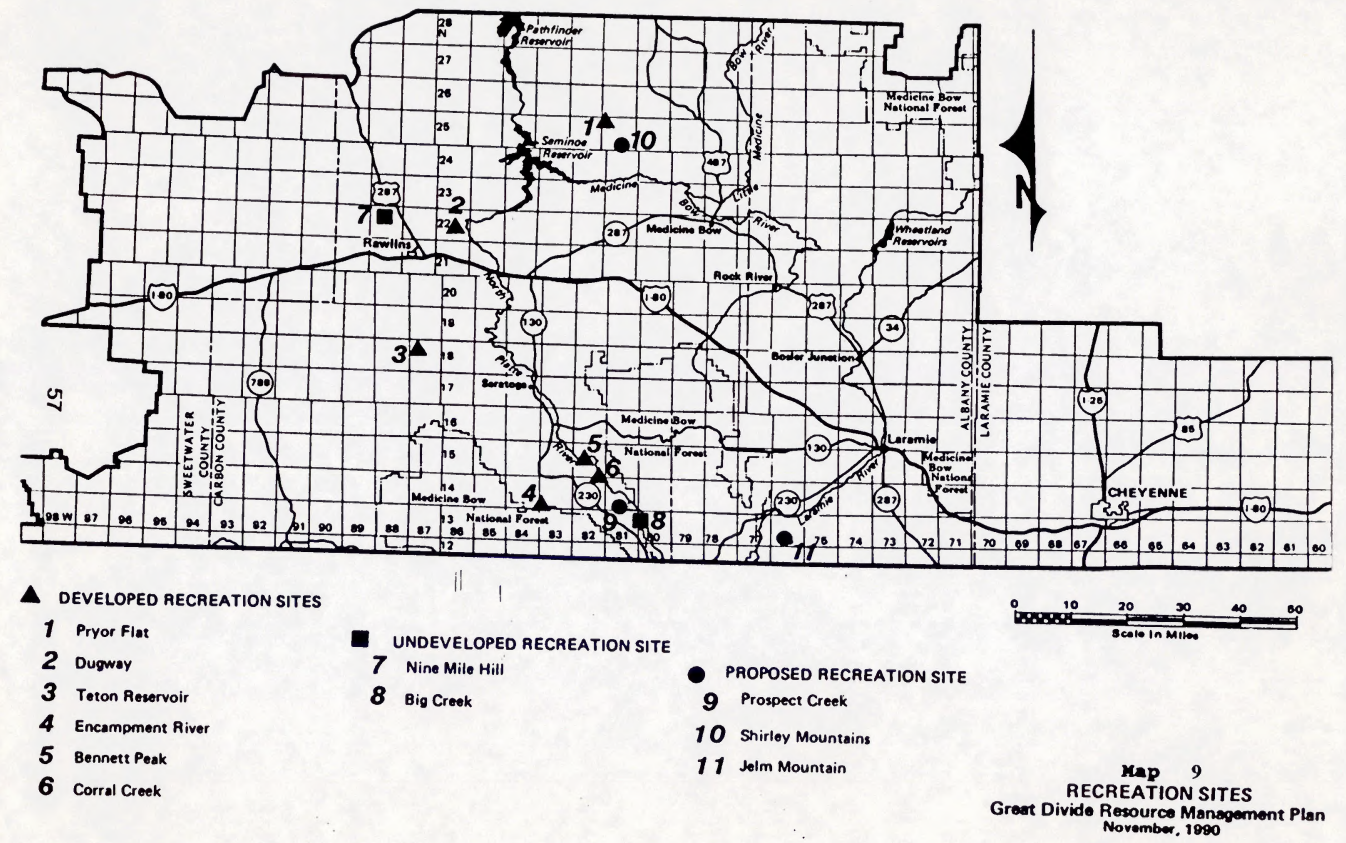


0

0

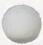




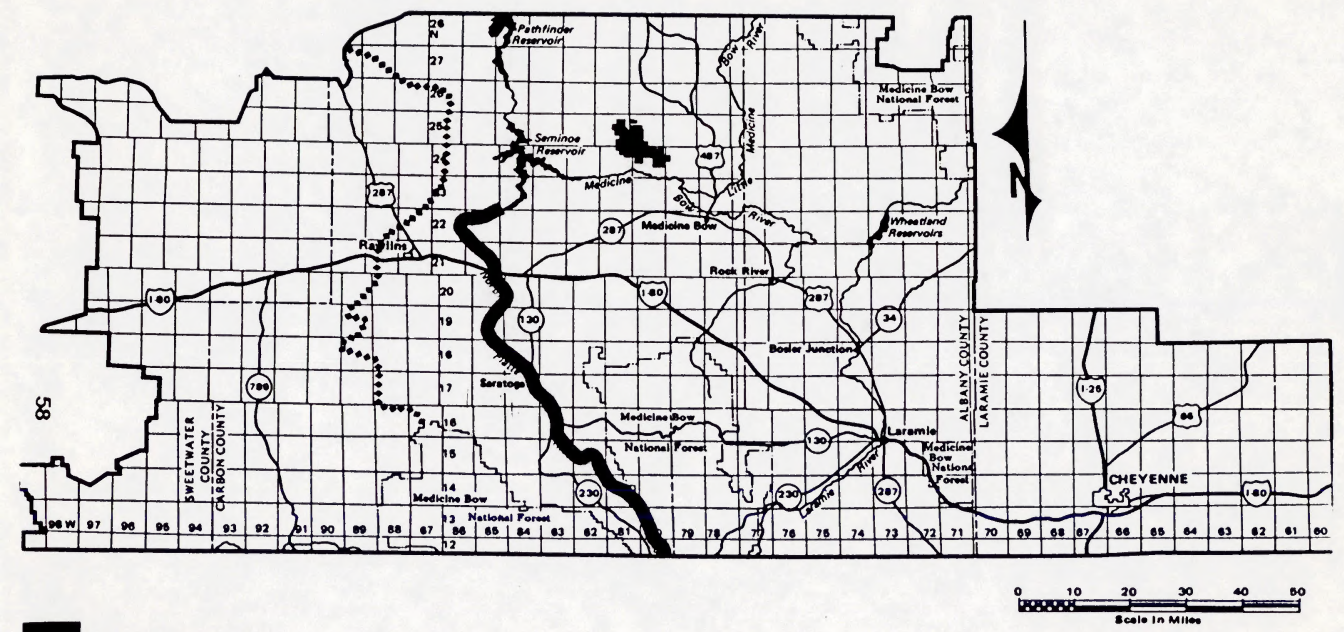

Shiriey Mountain Caves

North Platte River

•ece." Continental Divide Netionai Scenic Trail

Map 10

SPECIAL RECREATION MANAGEMENT AREAS Great Divide Resourco Manogement Plan 
0

0

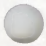




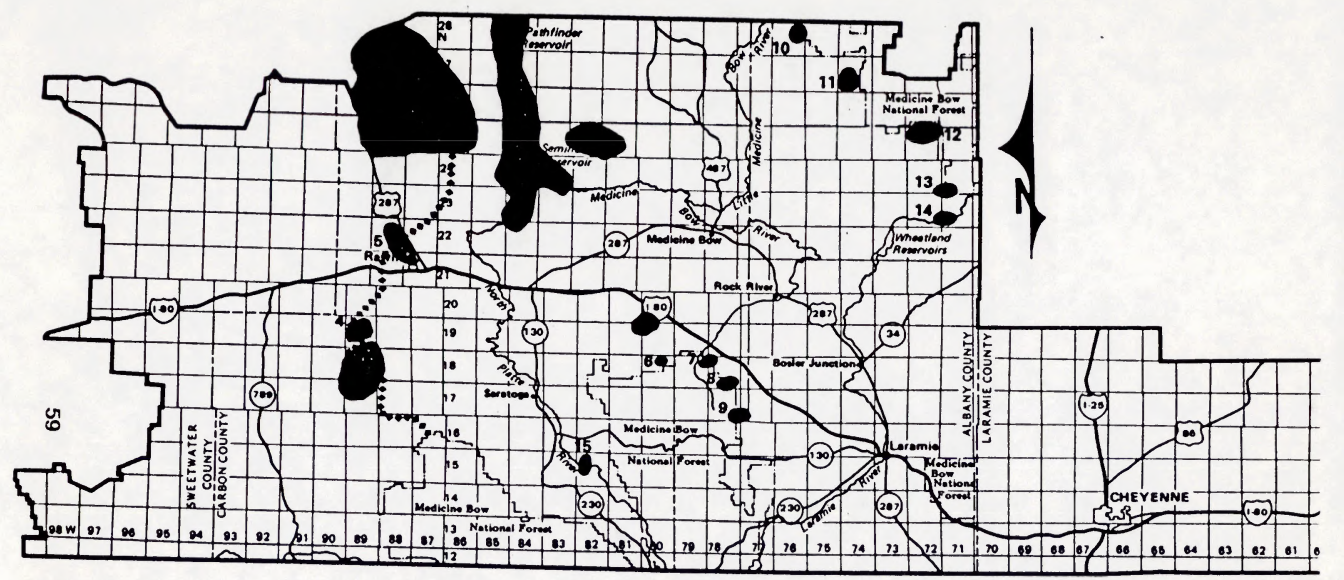

\begin{tabular}{|c|c|}
\hline & $\begin{array}{l}\text { Ares of Accoss Noeds } \\
\text { Continental Divide Trail }\end{array}$ \\
\hline 1 & Elk Mountain \\
\hline 2 & Shirley Mountains \\
\hline 3 & Miller HIII \\
\hline 4 & Atlantic Rim \\
\hline 5 & Rowlins Uplift \\
\hline
\end{tabular}

$\begin{aligned} 6 & \text { White Rock Cenyon } \\ 7 & \text { Arlington } \\ 8 & \text { Woodedge } \\ 9 & \text { Seven Mile } \\ 10 & \text { Little Medicine } \\ 11 & \text { Toltec } \\ 12 & \text { North Laramie River } \\ 13 & \text { Pine Mountain-Split Rock }\end{aligned}$
Sugerloaf
Big Croek
Seminoe-Pathfinder Peservoirs
Ferris Mounteins

Map 11

AREAS OF ACCESS NEED Great Divide Resource Mansoment Pla November, 1990 


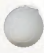

0

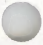




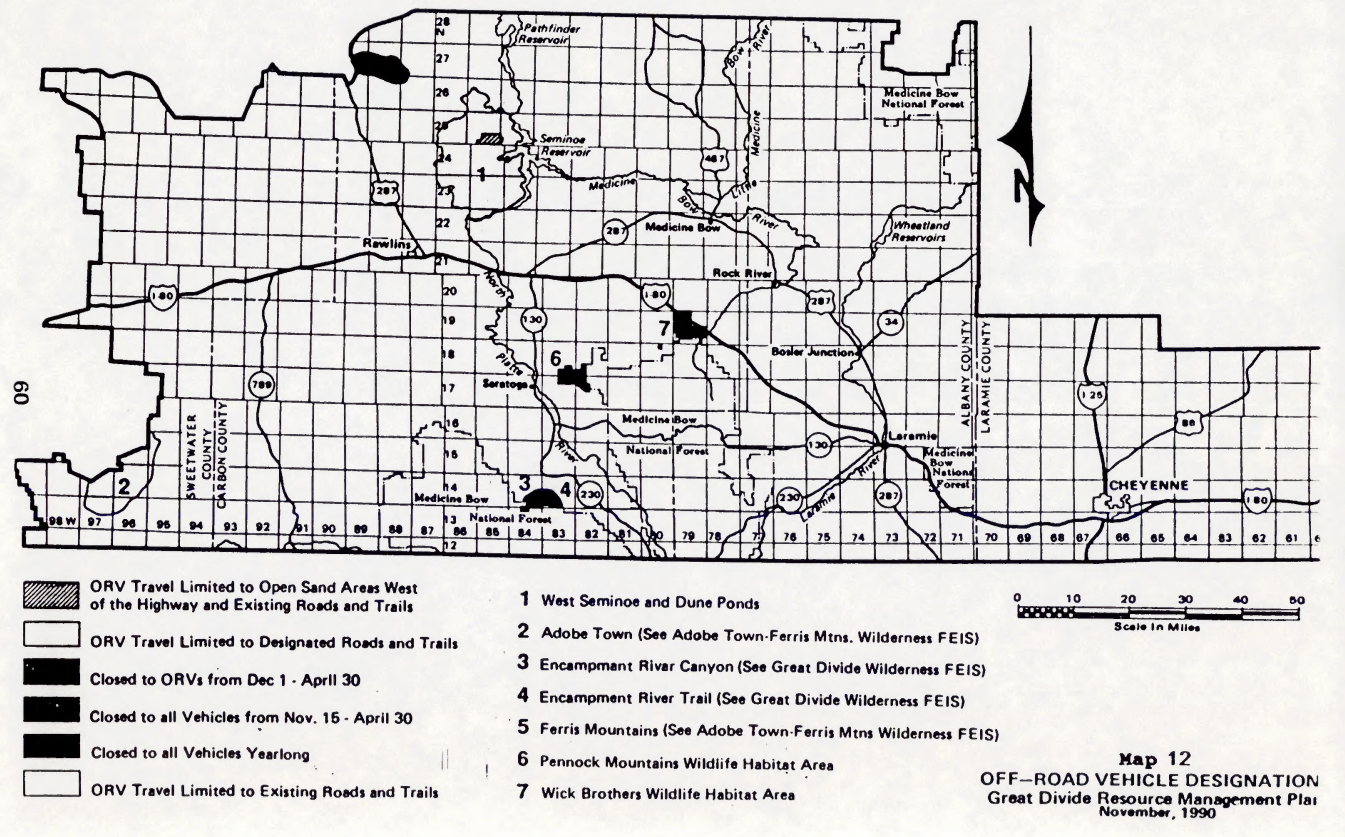


0

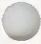

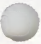


resources, past present, and future, will provide more uniformity in the mitigation
process.

The purpose ofthe guidelines used to protect resources from human disturbance are (1) to reserve, for the BLM, the right to modify the operations of all gurface and other human presence disturbance activities as part of the statutory requirements for environmental protection, and (2) to inform a potential lessee, permitee, or operator of the requirements that must be met when using BLM-administered public lands. These guidelines have been written in a format that will allow for (1) their direct use as stipulations, and (2) the addition of specific or specialized mitigation following the submission of a detailed plan of development or other project proposal (activity plans for the 15 sites), and an EA. The individual EAs that will be written within the HMP Area currently without a standardized set of permit or operation stipulations can use the mitigation guidelines as stipulations or as conditions of approval, or as a baseline for devloping specific stipulations for a given activity or project.

\section{.34A.6 Planned Actions HMP Proqress Report}

Table 2 depicts the HMP Progress Report for the Planned Actions segment of the HMP. This will be assessed and completed on periodic basis. This table also appears in the objectives (see .33) and Evaluation/Monitoring (see.35) portions of the HMP.

\section{.34B Information Sources to Support Actions}

This portion of the HMP discusses pertinent sport harvest techniques or other population management programs as they are defined by the State Wildife Agency (WGFD) and are pertinent to the success of the HMP. The WGFD is responsible for managing and regulating resident wildlife populations. Since the major objective of this HMP is to increase the size and improve the viability of bighorn sheep, the population management program for this species, as practiced by the wGFD, will be discussed. Individual EAs for each project area will discuss relevant planned population rehabilitation programs, introductions, reestabllishments, and wildife release porgrams proposed by the WGFD at the time those documents are prepared. This has to be completed at that level since populations are dynamic and time spans will be in effect which could alter decisions contrary to any desired outcomes if done in advance.

The post-season population objective for the Laramie Peak Bighorn Sheep Herd is 500 sheep. A population model utilizing the most recent data was analyzed by the wGFD for this herd from June 1992 to May 1993. The POP-II model was used which assumes that no natural mortality occurs during the hunting season from Sept.1 - Oct. 31 . This model, although based on limited data, reveals a decline in population numbers from 216 (1988-1992 averages); 188 (1992); to 168 (proposed 1993), an 118 decrease. Post-season classifications reflected ratios of 12 rams/100 ewes/21 lambs in 1992 compared to $26 \mathrm{rams/100}$ ewes/46 lambs in 1991. It must be noted that the particular habitats for bighorn sheep within the HMP Area are remote and rugged, therefore, several sub-herds may not be totally accounted for since they are difficult to survey; data collection and sightings frequently seem to be by chance rather than a product of effort.

Relative to harvest/hunter statistics, in the Laramie Peak DAU Area (see Map 6) the bighorn sheep harvest has declined from 1983-1993, and has only been averaging 2.2 rams over the past five (5) years. Harvest peaked in 1983 at seven (7) rams. The 1993 hunting season prescribed four (4) licenses. Between $1988-1992$ a total of 31.0 rams were taken during the hunting season. Although there appears to be an adequate supply of rams at this time, the mobility and distribution of rams, the restricted public access, and the ruggeddness of Hunt Area 19 are some major factors contributing to the fluctuations in the ram harvest. The 1992 hunter success rate was only 258 (the lowest since 1986) compared to the 1991 success rate of 758 . A 508 success rate was expected for the 1993 hunt. Hunters spent 41 days/ram obtained in 1992 compared to 24.3 days/ram in 1991 .

WGFD personnel, hired through the Wyoming Cooperative Fish and Wildilfe Research Unit 
O

0

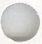


(Aug. 1989-June 1992) and BLM volunteers in cooperation with the wGFD, through the GDRA (July 1994) have been documenting sheep herd sizes in the Laramie Peak Range. The sample sizes from the BLM observations are smaller in scope than those of the WGFD. Although research supports a minimal harvest of rams, the population appears to be declining due to non-hunting mortality and lowered recruitment rates. The distribution of bighorn sheep, access restrictions, habitat characteristics (i.e. rugged terraine), and lack of funding limit data collection concerning these herds. Local residents, outfitters, and sheep hunters reported an overall decline in sheep numbers since 1983.

Low lamb/ewe ratios and declining ram/ewe ratios suggest that relatively few rams are being recruited. In addition, significant lamb mortality appears to occur after prehunt data are collected and prior to posthunt data collection. Currently, high lamb mortality has been documented for the Laramie Peak sub-herds in the late summer and fall for 1986, 1989, 1990, and 1992. Poor nutrition affecting the lactating ewes with lambs has been hypothesized as a factor affecting lamb survival. Studies show that sheep living in higher quality forage habitats have higher lamb production and survival characteristics versus those sub-herds located in low quality forage production areas. Documentation also shows that there is a displacement of ewes with lambs from the riparian zone on creeks (e.g. Duck Creek) to slopes with lower quality forage when cattle are present. Lamb mortalities that are reported are probably a result of poor milk production from ewes and overall weaker lambs. Weak lambs or ewes with lambs may be predisposed to more predation and diseases, which effect the universal viability of the herds.

In its present condition, the Laramie Peak DAU has good quality, well-distributed sheep habitat for small, isolated herds, but will require more open-grass/shrub-grass habitats near rocky outcrops to remain stable and increase in size and viability. Currently, breeding and lambing areas are restricted with too much overstory being present, therefore, these need to be opened up and increased in size. Travel corridors for sheep are also restricted which force populations to become isolated. This affects genetic diversity and multiple herd development. The lack of sufficient amounts of suitable, open habitat stresses sheep, limits the amount of available forage, restricts movement between important seasonal ranges, and denies intermixing of local population concentrations.

\section{.34C Water Right Considerations}

Before the Bureau allocates funds for maintenance, development, or construction of any water-related facilities involving nonreserved water for which a state appropriative water right is required, the Bureau must determine whether the United states can obtain the State water right. In the state of Wyoming there is a minimum threshold of " $X$ " acre feet that require water rights. At this point in time, there are not any anticipated projects that will require large amounts of water that will surpase this threshold. The largest probable project will involve water catchments (collecting rainwater) that do not require specific state water rights. If any projects surpass the permissable limit, then it will be assessed at the EA level for each site-specific proposed project area, 
0

0

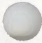


A description of studies and analyses used to evaluate and monitor progress of planned actions to accomplish the objectives in. 33 must be stated to thoroughly understand, evaluate and monitor the success rate of all of the completed programs in the HMP. Form 6780-2 (Table 2) summarizes relative objectives and planned actions within site-specific project proposals (15 total) and programs. Since the HMP is a general document to describe the entire habitat management area, and individual EAs will be written for each site-specific project proposal area, then the estimates of personnel, workmonths, season, and costs needed on an annual basis to achieve evaluation and monitoring of projects will be completed at the EA level. Some EAs may not be prepared for several years, therefore, with changing intervals and economics an analyses involving these topics will become obsolete and inefficient if prepared in 1993.

There will be several different types of inventories that will be completed for each site-specific EA. Inventories for bighorn sheep habitat requirements include forage quantity and quality (winter, spring, summer range) and proximity to escape terrain, water sources near escape terrain, salt/mineral licks, visibility quantity and quality (vegetation types/tree-shrub crown cover), escape terrain (areas within -825 feet near steep, rocky terrain, with >808 slope), thermal habitats, and use of migration corridors. The inventories that will be used to assess bighorn sheep and range conditions and conflicts include abundance of steep escape terrain, abundance of vegetation types that are in low growing open areas known to provide sheep forage (near escape terrain), abundance of southerly aspects, annual precipitation and presence of reliable water sources, and absence of livestock and other human activities and development that would threaten sheep and sheep habitat. Inventories for bighorn sheep populations include relative density-trend counts for population sizes and sex-age structures, census-classifications summing the maximum unduplicated count for each class, and structure/sex-age categories that include lambs, yearling males, yearling females, ewes, and four classes of rams based on $3 / 4$ curl horn increments. These are all coded in Table 2 according to Inventory Habitat (IH), Inventory Range (IR), and Inventory Population (IP). Throughout the life of this plan, when specific planned actions are determined, the codes will be added to the evaluation/monitoring column in Table 2 for each site-specific planned area (EA).

Monitoring components of the HMP include assessing the changes in the quantity and quality of the various inventories, and assessing the changes in use. These are also coded in Table 2 as Monitoring Habitat (MH), Monitoring Range (MR), and Monitoring Population (MP). Again, these activities will be incorporated into the document when planning occurs for a site-specific area (EA).

\section{.35.A. Special Studieg - Laramie Peak Bighorn Sheep Study}

The Laramie Peak Bighorn Sheep Study was initiated on July 1, 1989. The Wyoming Game and Fish Department (WGFD) funded the study. Dan Hengel was hired through the Wyoming Cooperative Fish and Wildlife Research Unit as the primary researcher on the project. Intensive field work began in late August of 1989 . Field work on the study ended in June 1992 and a final report was expected in 1993 , but to date has not yet been completed. The WGFD is expected to have a report in the near future.

Seasonal movements, distribution and habitat use were determined by following telemetered sheep on a yearlong basis using ground and aerial surveys. The sheep were ear tagged as well, blood samples and body measurements were taken to determine population composition, productivity and population dynamics. A total of fifteen (15) ewes were captured during the study. Lamb mortality factors were investigated. Fecal samples were taken to determine the rate of lungworm infestation. Nutritional quality of the sheep diets and forage habits were determined from fecal pellet analyses and feeding site examinations. Competition for space and forage between bighorn sheep and other ungulates was also documented. 
0

0

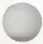


Results of portions of the study were reported in 1992 at the Biennial Symposium of the Northern wild Sheep and Goat Council and are as follows:

\title{
Population Dynamics, Seasonal Distribution and Movement Patterns of the Laramie Peak Bighorn Sheep Herd (Hengel et al., 1992)
}

\begin{abstract}
Radio-collared adult bighorn sheep ewes and associates were relocated from fall 1989 to spring 1992. The Laramie Peak bighorn sheep herd appears to be stable to declining based on herd unit numbers and sexratios. Annual adult ewe mortality was 10.88 . Mortality of three radioinstrumented ewes was caused from a fall, from Pasteurella sp., and from coyotes. Lambing rates were as high as 758 , but lamb survival was 338 or less. Lungworm infection levels were higher than levels found in other sheep herds in Wyoming. Ewes exhibited movements greater than $51 \mathrm{~km}$ from wintering areas to lambing areas. Bighorn ewes exhibited a social intolerance of domestic livestock when cattle were grazing in riparian areas.
\end{abstract}

The BLM also had two (2) seasonal SCA students tracking bighorn sheep populations in the Laramie range in July 1994. The time span for this project was only 3 weeks, therefore data was limited. Sheep were found to be in isolated pockets throughout the range. There was a definite display of competition in the riparian areas between sheep and livestock. Livestock displaced sheep to poorer quality forage habitat areas. There were few lambs found at this time. A report has been filed with the WGFD in August 1994 .

\section{.35.B. Evaluation/Monitoring Annual Costs}

The Laramie Peak HMP is an umbrella document in which individual EAs will be written and implemented for the fifteen (15) habitat improvement projects for bighorn sheep (see .34A.2). Since this document encompasses an extremely large acreage of land and some of the projects may not be implemented for years to come, a true representation of estimates of personnel, workmonths, season, and costs would not be accurate at this level of documentation. These analyses will be completed at the EA level for each area project on a site-specific basis.

The RMP requires that certain evaluation and monitoring analyses be completed for the Resource Area. These activities include, but are not limited to, inventories on raptors, prairie dog towns, sage/sharp-tailed grouse, mule deer, elk and riparian habitats. The major inventory that must be completed for each project area focuses on bighorn sheep. Monitoring studies include those on elk, bighorn sheep, and riparian habitats. Form 6780-2 (Table 2) describes a general outline of the estimated dates, activities, and costs of the 15 project activities within the HMP Area. It must be noted that these are merely estimates and can be modified at any time to reflect the most current information pertaining to local, state, and federal economics at that time. 
After the Laramie Peak HMP Objectives (.33), Planned Actions (.34 A-C), and Evaluation and Monitoring $(.35)$ efforts have been prepared and included on Form 6780-2 (see Table 2), then the Progress report immediately follows. This is also Form 6780-2, but the progress and completion dates of the individual project activities are documented on this form. Since this section basically outlines progress throughout the HMP, Then Table 2 will also be placed here for a quick reference to this issue. This provides Resource Area specialists and management personnel the opportunity to view and compare these three (3) principle HMP sections together and verify their coordination. It also permits all parties to "track" HMP progress throughout it's implementation.

Many factors must be considered when planning, implementing, and evaluating numerous project activities (15 total) for an area as large as the Laramie Peak HMP Area. Since many of these projects may not take effect for geveral years, and ecosystems are so dynamic, the processes for evaluation and monitoring may change. As societieg' attitudes change regarding wildife and their habitata, as well as the impacts humans have on wildlife and associated habitats, there may even be changes in the individual project plans and overall objectives. Events such as this must always be considered when dealing with a 10-15 year HMP. As stated before, the major goal of the HMP is to improve bighorn aheep habitats and maintain viable populations throughout the Medicine Bow National Forest and adjacent BLM lands.

Other project activities such as in-stream structures, aquatic wetland improvements (plantings), riparian improvement fencing, waterfowl nesting structures, prescribed burns and upland fencing modifications may take place throughout the HMP Area to improve habitat for not only bighorn sheep, but a diversity of wildlife as well. Inventories/monitoring of other wildife species may also occur in addition to the major inventory and monitoring for bighorn sheep. As stated above, Table 2 will also be placed in this section for an overail progress report of the HMP. 
0

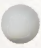

0 
TABLE 2 hABITAT MANAGEMENT PLAN PROGRE88 REPORT

\begin{tabular}{|c|c|c|c|c|c|}
\hline OBJECTIVES & $\begin{array}{c}\text { DATE } \\
\text { COMPLETED }\end{array}$ & PLANNED ACTIONS & $\begin{array}{c}\text { DATE } \\
\text { COMPLETED }\end{array}$ & EVALUATION/MONITORING & $\begin{array}{c}\text { DATE } \\
\text { COMPLETED }\end{array}$ \\
\hline $\begin{array}{l}\text { Laraie Peak meP } \\
\text { 1. Improve the } \\
\text { distribution of } \\
\text { bighorn sheep } \\
\text { populations and } \\
\text { associated genetic } \\
\text { diversity by } \\
\text { increasing the herd } \\
\text { numbers from } 173 \\
\text { sheep (1993) to } 500 \\
\text { sheep (2010). } \\
\text { 2. Identify, protect, } \\
\text { and enhance bighorn } \\
\text { sheep habitat; } \\
\text { improve/increase } \\
\text { quantity and quality } \\
\text { of vegetation/forage } \\
\text { areas by } \\
\text { approximately } 9,000+ \\
\text { acres. } \\
\text { 3ursuit of land } \\
\text { exchanges/logal } \\
\text { public access, } \\
\text { improve hunter } \\
\text { aucces } \\
\text { rates/distribution, } \\
\text { improve } \\
\text { recreational uses. }\end{array}$ & & $\begin{array}{l}\text { Laraieie Peak HuP - General } \\
\text { Prescribed burng; } \\
\text { Small commercial logging; } \\
\text { Firewood sales for habitat } \\
\text { improvement and diversity. } \\
\text { Fence modifications for } \\
\text { wildlife movements. } \\
\text { Aquatic/wetland improvement } \\
\text { using fence modifications, } \\
\text { update AMPs, in-stream } \\
\text { structures. } \\
\text { Riparian improvement: } \\
\text { fencing/in-stream } \\
\text { structures/vegetation } \\
\text { plantings. } \\
\text { Reservoir development: } \\
\text { waterfowl nesting } \\
\text { structures. }\end{array}$ & & 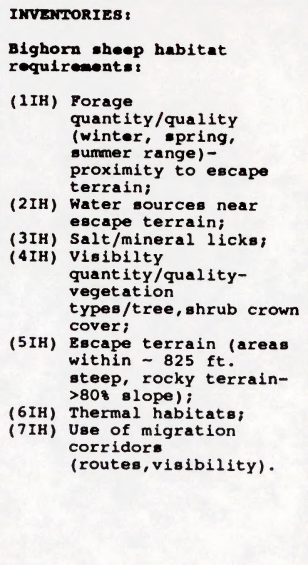 & \\
\hline
\end{tabular}

1. Lis apecific HMP objectives as developed from RMPMFP planning documents or at otherwise approved.

2. Liat apecific planned actions to be initiated to meet each apecific objective.

3. Liat achedule evaluation/monitoring atudy(s) planned to evaluate accompliahments.

4. Enter completion date for each objective, action, or evaluation/monitoring atudy a accompliahod. 
0

0

0 
UNITED ITES

DEPARTMENT C IE INTERIOR

BUREAU OF LA. - MANAGEMENT

TABLE 2 HABITAT MANAGEMENT PLAN PROGREBS REPORT

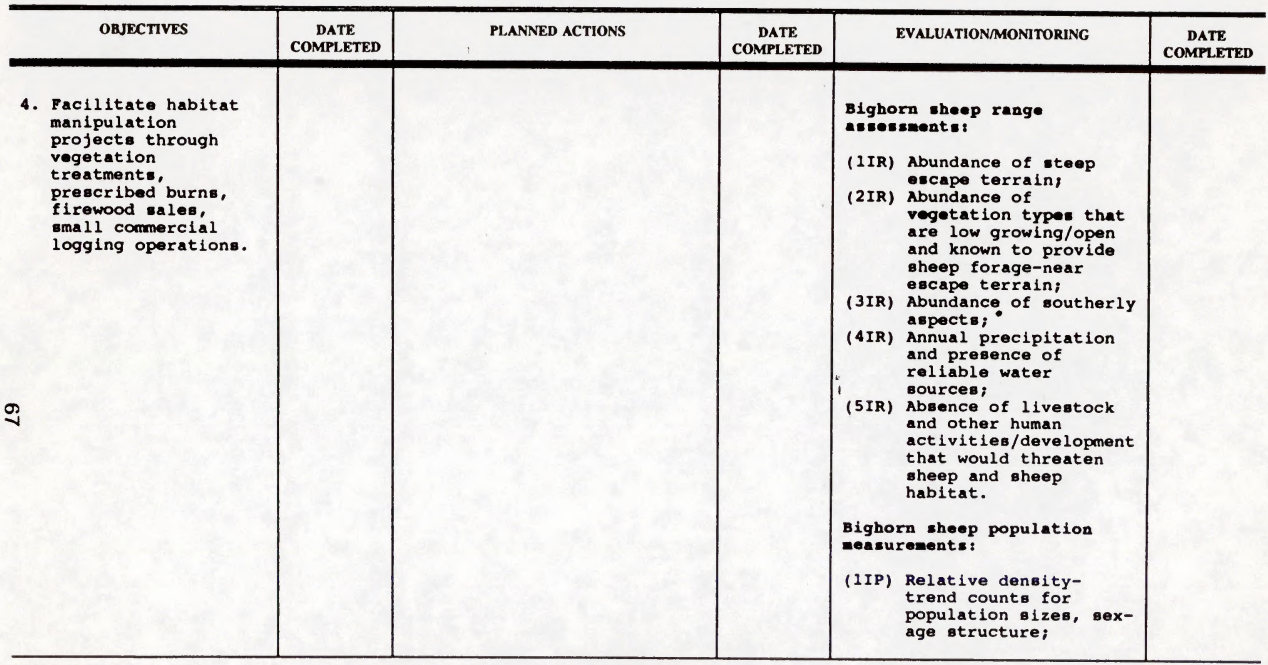

INSTRUCTIONS

1. List apecific HMP objectives an developed from RMP/MFP planning documents or at otherwive spproved.

2. List apecific planned actiona to be initiated to meet each apecific objective.

3. Liat achedule evaluation/monitoring atudy(o) planned to evaluate accompliahmemts.

4. Enter completion date for each objective, action, or evaluation/monitoring atudy an accompliehed. 
0

0

O 
UNITE. SATES

DEPARTMENT OF THE INTERIOR

BUREAU OF LAND MANAGEMENT

TABLE 2 hABITAT MANAGEMENT PLAN PROGREBB REPORT

\begin{tabular}{|c|c|c|c|c|c|}
\hline OBJECTIVES & $\begin{array}{c}\text { DATE } \\
\text { COMPLETED }\end{array}$ & PLANNED ACTIONS & $\begin{array}{c}\text { DATE } \\
\text { COMPLETED }\end{array}$ & EVALUATION/MONITORING & $\begin{array}{c}\text { DATE } \\
\text { COMPLETED }\end{array}$ \\
\hline ஜ & & & t & 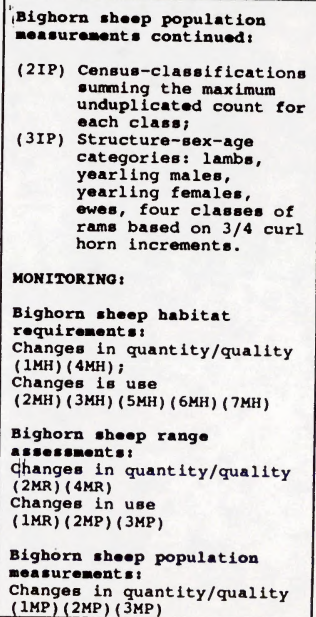 & \\
\hline
\end{tabular}

1. Lis apecific HMP objectives as developed from RMP/MFP planning documents or as otherwise spproved.

2. List specific planned actions to be initiated to meet ench apecific objective.

3. Liat achedule evaluation/monitoring atudy(t) planned to evaluato accompliahments.

4. Enter completion date for each objective, action, or evaluation/monitoring atudy a accompliahed. 
0

0

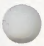


habitat MANAGEMENT PLAN PROGREsB REPORT

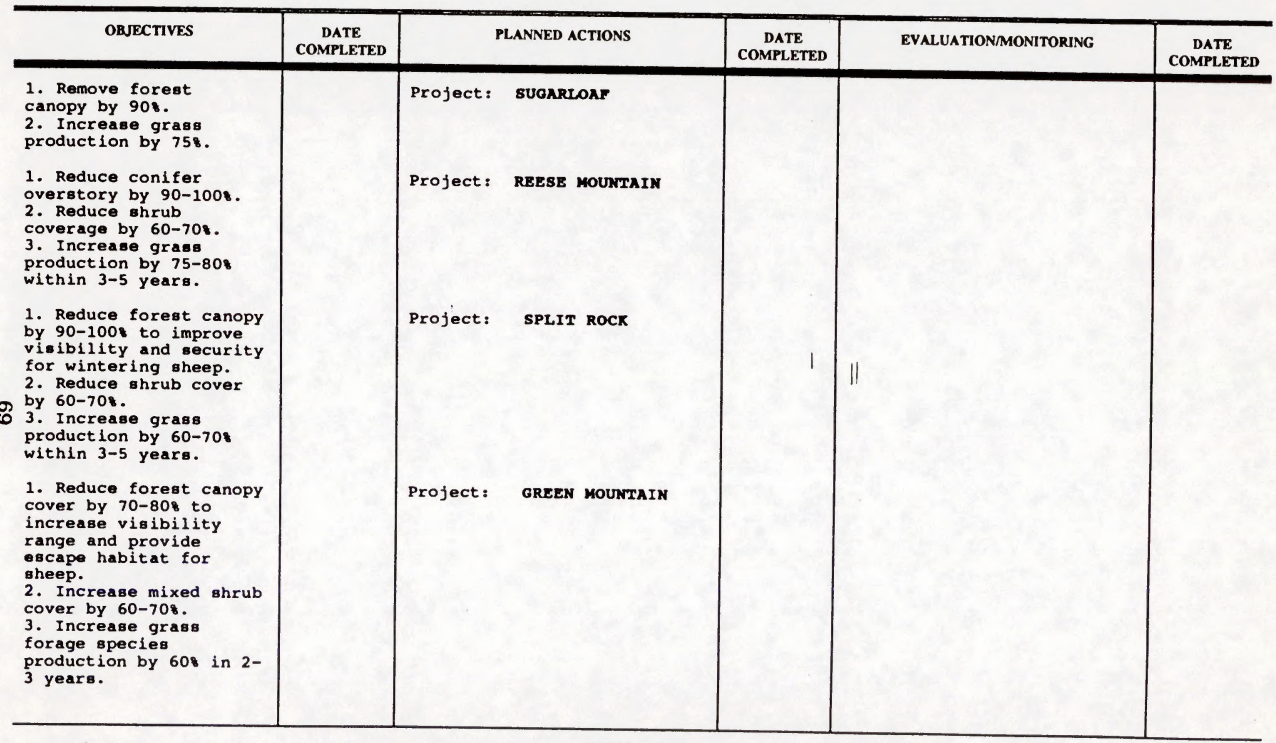

3. List achedule ovaluation/monitoring atudy(a) planned to evaluate accompliahments.

4. Enter completion date for each objectivo, action, or ovaluation/monitoring atudy a accompliahed. 
HABITAT MANAGEMENT PLAN PROGRESB REPORT

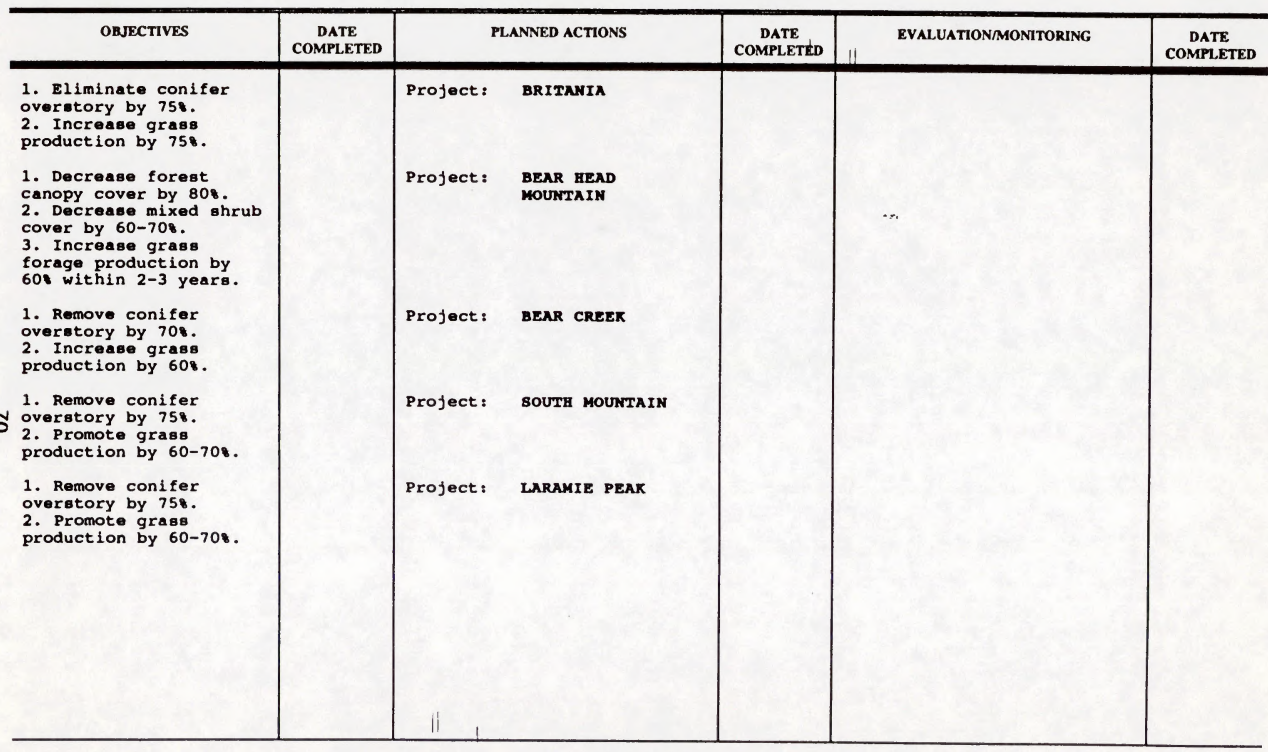

INSTRUCTIONS

1. Lim opecific HMP objectives as developed from RMP/MFP planning documents or a otherwies approved.

2. List apecific planned actions to bo initisted to meet each apecific objective.

3. Liat achedule ovaluation/monitoring atudy(o) planned to avaluate accompliahmento.

4. Enter completion date for each objectivo, action, or evaluation/monitoring atudy as accompliahed. 


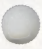

0

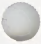


HABITAT MANAGEMENT PLAN PROGREB8 REPORT

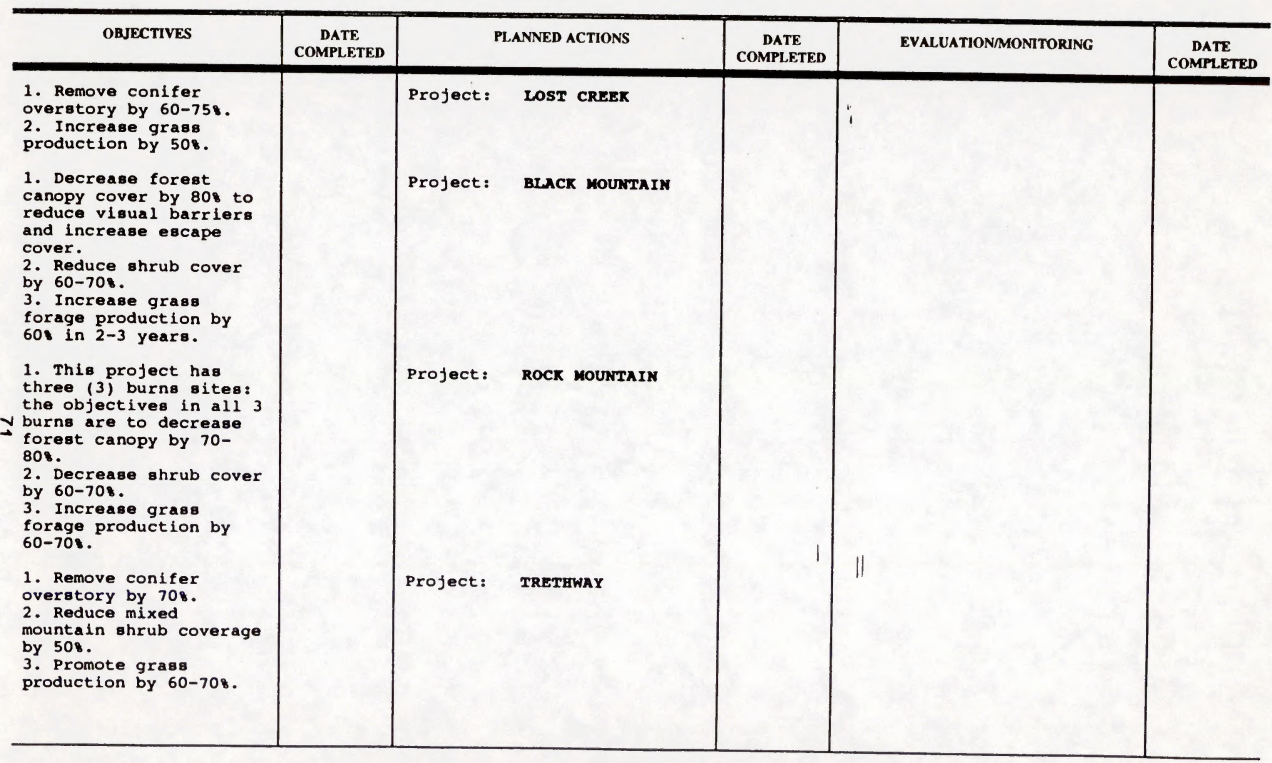

3. Liat achedule evaluation/monitoring atudy(a) planned to evaluate accompliahmenta.

4. Enter completion date for each objective, action, or evaluation/monitoring study as accompliahed. 


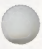

0

O 


\section{HABITAT MANAGEMENT PLAN PROGRES8 REPORT}

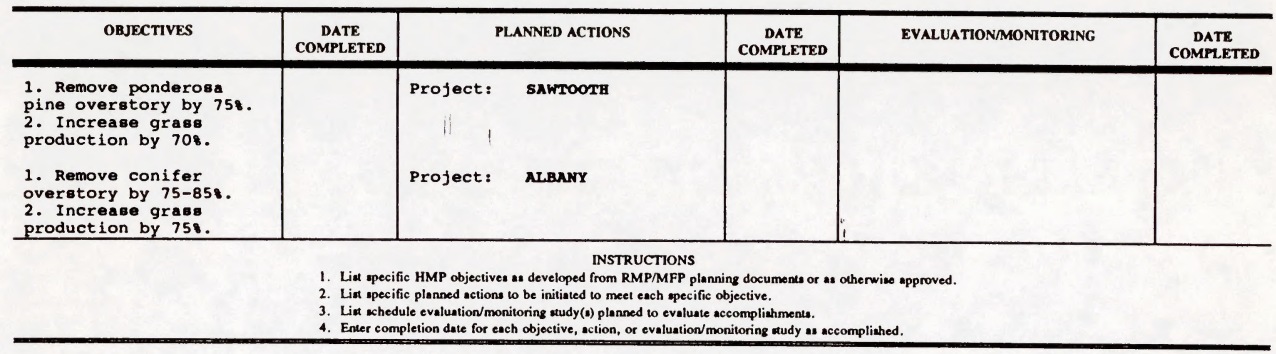


0

0

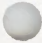


Coordination of HMP development with other BLM resource program is necessary to ensure multiple-use managenent consistent with the GDRA RMP and PRRA RMP decisions. This requires scheduling and arrangement for timely input of other concerned disciplines and interests. This will be done in finer detall at the EA level for each project proposed. If and when other resource activity plans are implemented in the HMP Area, correlation and crose-referencing to this HMP and associated EAs will occur to ensure that priority species and their habitat management objectives are properly included.

Individual EAs for each project proposed will differ depending upon location, agencies and environmental groups involved, timing, etc., therefore it is essential that at that time all the interested parties are contacted and the plans are openly discussed. The following sections provide the basic concept for how these interrelationships might be developed and presented.

\section{.37A Siliviculture Procedures}

The two most predominate forest vegetation types in the area are the ponderosa pine and the Douglas-fir. Each type is named after the anticipated climax plant species for the site. Ponderosa pine usually occurs in the lower elevation, drier sites. Another forest type, woodland, designates forests with very low stocking (usually less than 25 percent canopy cover) and is comprised of coniferous trees such as ponderosa pine, limber pine, and funiper.

Recent on-site analysis and past inventory information indicate that there has been a trend of steadily increasing trees density. This trend of higher tree density has been commonly noted in ponderosa pine and Douglasfir forests throughout the Rocky Mountain region. The trend has been largely attributed to either the direct or indirect exclusion of low intensity surface fires. These surface fires served the functions of controlling tree density, recycling nutrients, retaining low levels of dead wood biomass in the area.

Prior to the influence of European settlement, low-intensity fires occurred in ponderosa pine forests between every 10 to $60+$ years. The high tree density prior to the MPB epidemic and the accumulations of needle debris indicate that fires have not occurred in this area for many years.

The exclusion of fire was probably a major contributing factor to a MPB epidemic that occurred in the mid 1980s. The lack of fires result in higher tree densities, which cause greater competition between the trees for water and nutrient requirements. When a natural disturbance event like the MPB epidemic occurred, the stress on the trees from excessive competition caused very high tree mortality. In some locations within the HMP area that mortality has almost reached 100 percent of the large diameter trees.

Present forest conditions are undesireable for a number of reasons. Where MPB mortality has been severe:

(1) The rapid, nearly 100 percent, mortality of the large-sized ponderosa pine has limited opportunities for successful natural reproduction, because of the cyclic cone crops inherent to ponderosa pine. Regeneration is also limited to some extent by the heavy accummulations of dead and down trees. The majority of the trees that survived the MPB epidemic are small-diametered, but not necessarily young. Their small diameter is a reflection of past suppression by the larger, dominant trees. This suppression has resulted in mis-formed tree crowns with low crown to tree height ratios. Productivity, in terms of forest growth, is poor because of the mortality, blowdown, poor quality of the remaining trees, and low regeneration success. Consequent $y_{y}$, from a forest growth standpoint, the productivity of the area is far below potential. 
0

0

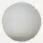


(2) The dead biomass creates a high fuel loading for the area. Current fuel loading in many locatione is estimated to be in excess of 40 tons per acre. This high fuel loading could result in unnaturally, very intense future wildfires that would kill the remaining live trees, which could otherwise survive normal, natural fires. These intense wildfires could also result in long-term losses in site productivity through damage to the soil resource, because of abnormally high fire temperatures. Intensive wildfires could easily spread to the neighboring, higher elevation Douglas-fir forest.

(3) Additionally, the standing and down dead biomass restricts viewing distances for bighorn sheep, which restricts opportunities for the species to utilize the area.

Where there has not been the MPB activity, forest conditions are still not desireable because of the dense stocking of trees. In addition to restricting big horn sheep utilization of areas, another concern is the high fuel loading of the living biomass. Past fire suppression has allowed these areas to achieve higher stocking levels than what would occur naturally. Consequentially, when fires do occur, they would be of a higher intensity and cause long term losees in site productivity.

Therefore, management actions are needed to allow these forest ecoystems to recover and restore itself to a more natural, healthier condition. The objectives of forest management for this area are to:

$$
\begin{aligned}
& \text { a. salvage a resource (wood material) while it still retains } \\
& \text { economic value. } \\
& \text { b. restore the natural functioning of these forest ecosystems. } \\
& \text { c. provide a healthy, forested landscape for human and wildiffe } \\
& \text { benefits. }
\end{aligned}
$$

Projects would most likely take the form of salvage harvesting operations in beetle-killed forest. In addition to achieving a short term objective of recovering a natural resource for human use, other long term objectives of the projects are to reduce fuel loadings in the area, improve vegetative landscape conditions to facilitate future prescribed burning for forest and wildife objectives, and remove standing biomass to improve site distances for bighorn sheep on site-specific locations to increase sheep use in the area.

The proposed activities would be implemented by the issuance of a timber sale contract with applicable atipulations. Work would start only after authorization is granted. The work would involve severing the trees with chainsaws or mechanized harvesters at a maximum of 1 foot above the ground.

Actual harvesting intensity would vary throughout the area, depending on the extent of mortality. Harvested trees would be individually selected. The objective is to remove between 40 and 60 percent of the standing and down, dead trees.

Merchantible material would be machine skidded to landings along the existing two-tracks and temporary spur roads. The material would then be hauled to processing facilities.

slash disposal method(s) would be determined after further on-site examination and would depend on the amount of slash. Two methods that would be considered are limbing/lopping and piling. Regardless of the method chosed, lash heights over 18 inches would not be permitted. To enhance long term productivity of the area, about 10 to 15 tons/acre of large woody debris would be left on site. 


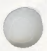

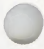

0 
Where tree regeneration is anticipated to be problem in place within the area, due to the intensity of the insect activity, the timber purchaser would be required to protect the healthy, advanced reproduction. No green (live) trees over 12 inches in diameter would be harvested. ilve trees under 12 inches would only be harvested after site-specific determinations are conducted related to tree vigor and wildilfe use.

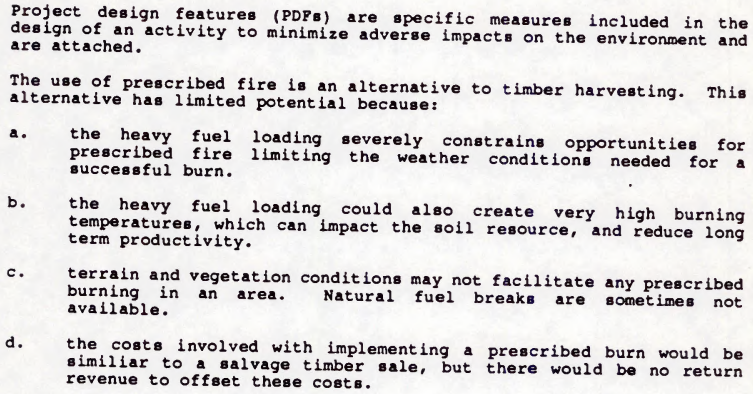

b. the heavy fuel loading could also create very high burning temperatures, which can impact the soll resource, and reduce long
term productivity.

c. terrain and vegetation conditions may not facilitate any prescribed burning in an area. Natural fuel breaks are sometimes not

d. the costs involved with implementing a prescribed burn would be similiar to a salvage timber sale, but there would be no return revenue to offset these costs.

Project Design Features for

Porest Management Activities Within the Laramie Peak HMP

1. Intermittent stream crossings with equipment would be at designated locations and subject to seasonal restrictions.

2. A raptor nest inventory would be conducted prior to finalization of any project layout.

3. No timber harvesting activities would be permitted between April 1 and June 30 to prevent impacts during the big game parturition period.

4. No timber harvesting activities would be permitted between September 1 and November 30 to prevent disturbance activities to recreational hunters.

5. Snags would be reserved for wildlife habitat under the following criteria:

a. Hard Snags

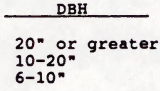

No. of snaqs/acre

A11

4

b. All soft snags would be retained 


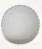

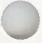

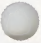


c. Reserved snags would be clumped and would be predominately located in areas that still have green trees. Where possible, these clumps will be spread throughout the area.

6. Proposed project would meet visual resource management requirements for the general area.

7. USDI-BLM Form No. 5450-3 (Contract for the Sale of Timber - Lump Sum Sale) would be used. Section 25 of the above contract provides for soil and watershed protection. Protection measures include:

- designating locations and placing restrictions on tractor stream crosilings.

- waterbarring skid trails at designated locations.

- restrictiong operations to minimize soil damage (compaction, etc.) because of soil moisture conditions.

- waterbarring and closing constructed roads.

Section 41 (Special Provisions) would include specifications on temporary road construction and maintenance, logging, slash disposal, and fire protection.

8. Prior to finalization of the project layout, all consultation required under 36 CFR 800 would be conducted to allow granting of clearance for cultural resources.

9. The following stipulation would be added to the timber sale contract:

"The Purchaser shall immediately report the discovery of any object(s) or resource(s) of cultural value discovered as a result of operations under this contract to the Authorized officer. The Purchaser shall suspend all activities in the vicinity of such discovery until notified to proceed by the Authorized officer. The Authorized officer shall evaluate, or have evaluated, such discoveries not later than five (5) working days after being notified and shall determine what action shall be taken with respect to such discoveries. The cost of this initial evaluation shall be the responsibility of the government. Any cost to the Purchaser which results from this initial suspension shall be boren by the purchaser. The decision as to the appropriate measures to mitigate adverse effects to significant cultural resources shall be made by the Authorized officer after consulting with the Purchaser. If avoidance is possible and the Purchaser and the Authorized officer agree to this avoidance, the contract shall be modified accordingly. However, if avoidance is not possible, or if avoidance is possible but the Purchaser elects, with the approval of the Authorized officer, to continue as per the original contract, the Purchaser shall be responsible for the cost of any additional investigations necessary for the evaluation, and for any mitigative measures."

\section{.37B Livestock Grazing Management Applicable to the Wildlife Program}

At this time there are not any AMPs planned, implemented or monitored within the HMP Area. There are two (2) planned CRMs for the PRRA that will be discussed at the BA level if the particular proposed project includes these. All proposed projects will coordinate wildlife habitat improvement objectives with livestock management objectives at the EA level. There are areas where livestock and wildife objectives are in conflict, therefore, these will be addressed at the 


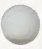

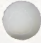

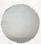




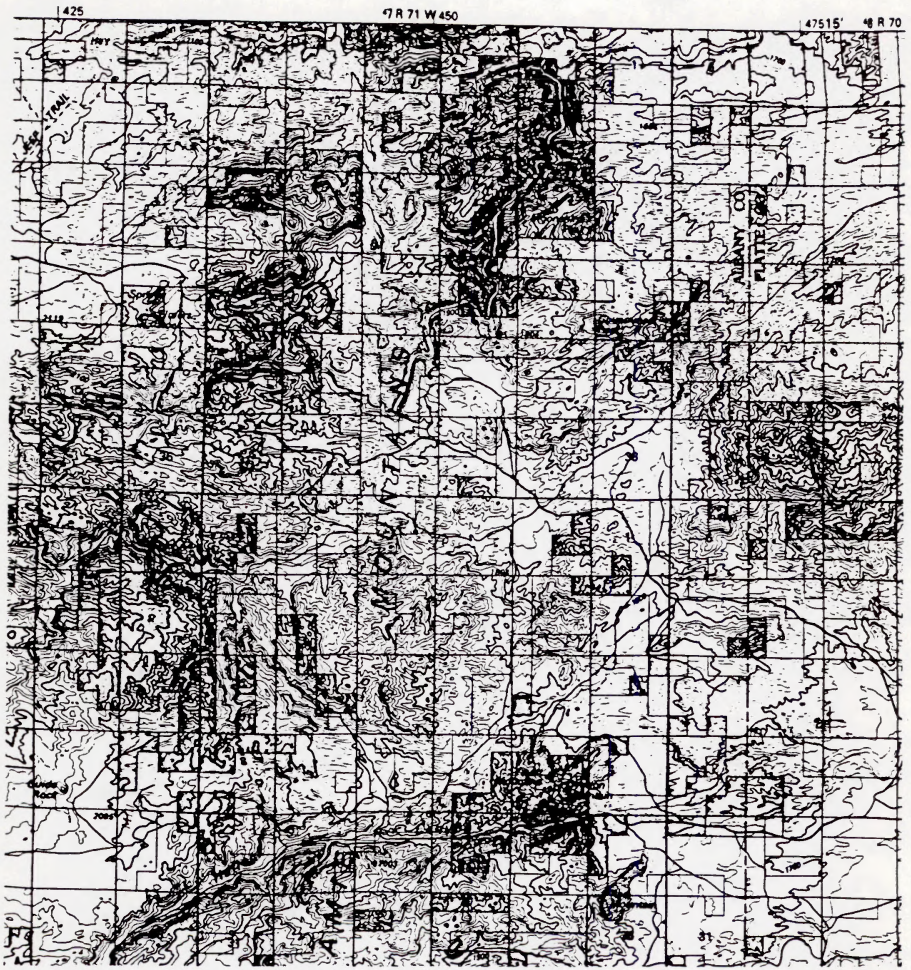

MAP 13

silviculture Procedures West of Moonshine Peak 
0

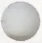

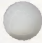




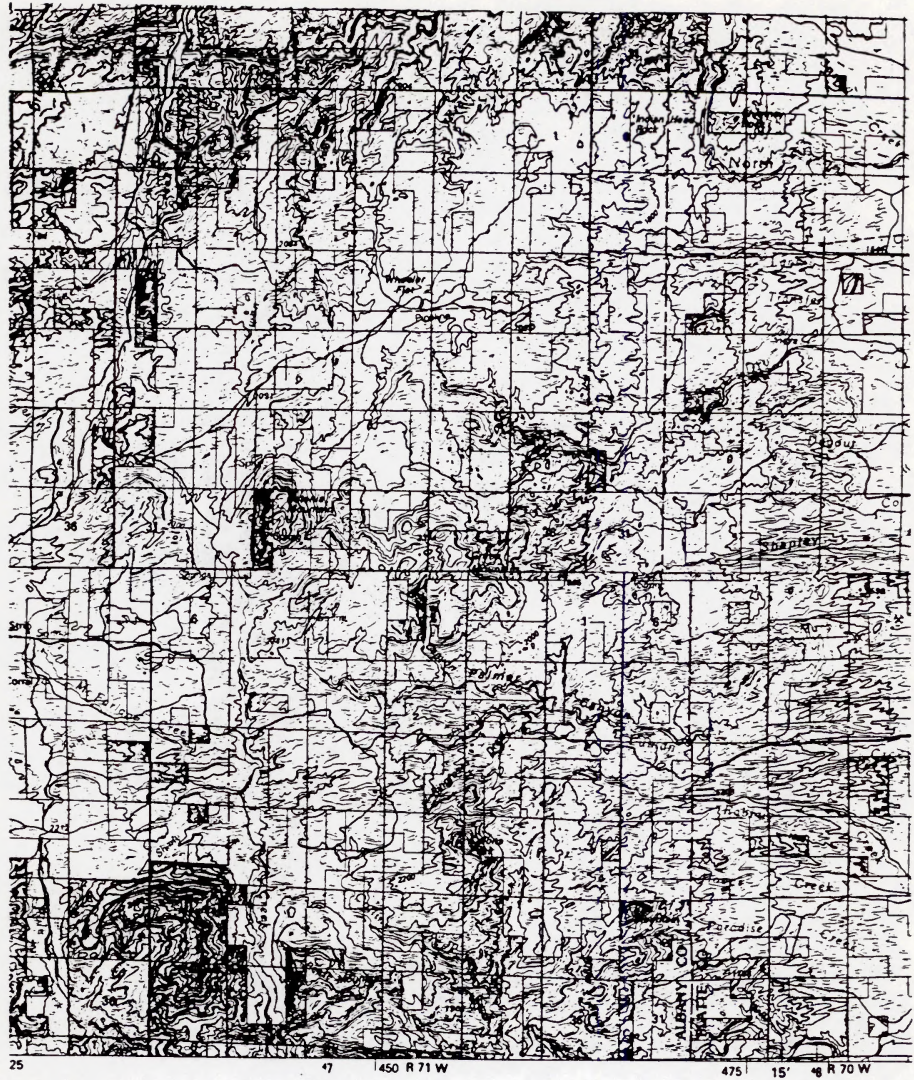

MAP 14

gilviculture Procedures for Britania Mountain/Pine Mountain 
0
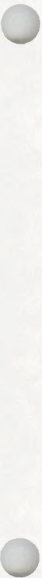


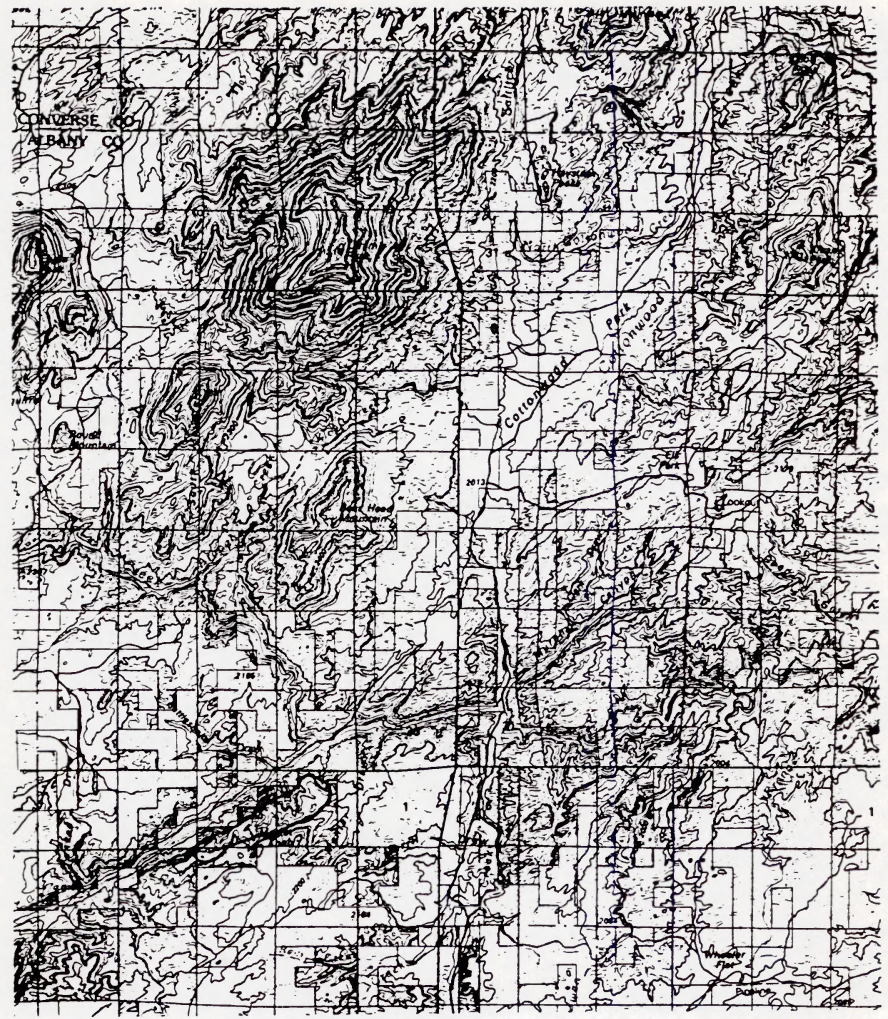

MAP 15

silviculture Procedures for Mentor Draw 


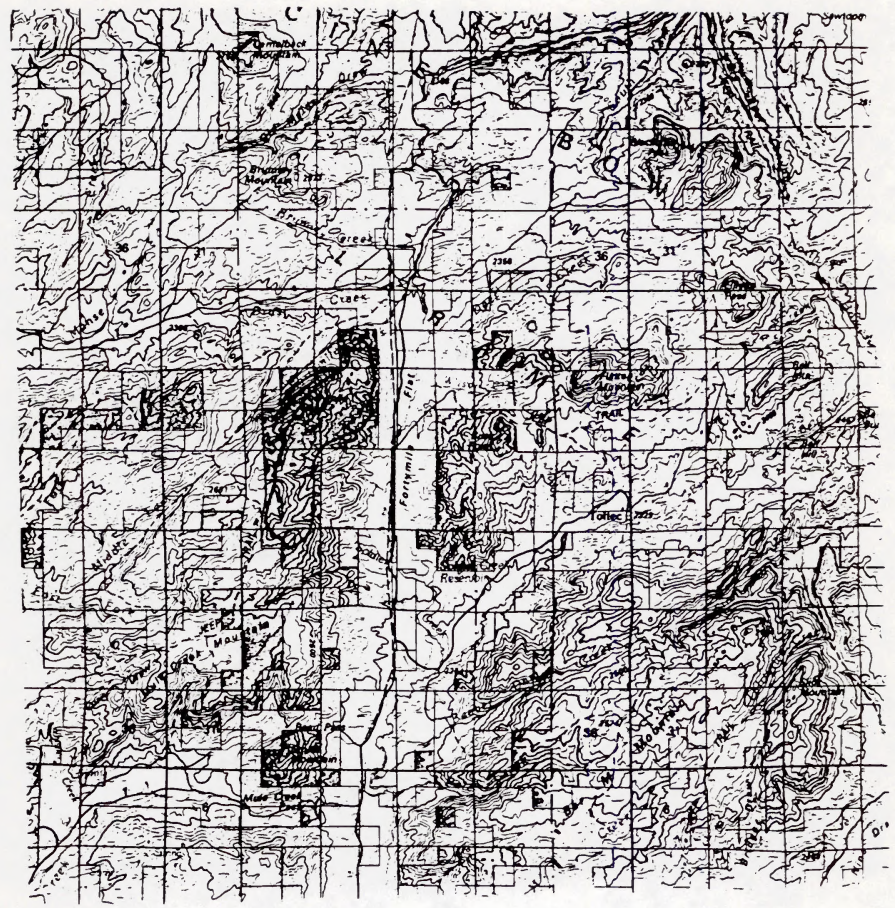

MAP 16

silviculture Procedure for Forty Mile Peak 
0

0

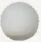


EA level. A livestock grazing gchedule does exist for the HMP Area and is recorded at both the GDRA and PRRA offices, but, due to the vastness of this area any questions pertaining to livestock management can be obtained at these of $\mathrm{fices}$ and will be addressed at the individual EA level. A cumulative approach will be utilized as more EAs are implemented. The GDRA RMP/EIS is the livestock EIS in the HMP Area. Habitat types are located in Appendix II of the HMP Plan.

\section{.37C Recreation Activitieg Relative to the Wildlife Program}

Recreation management objectives, according to the GDRA RMP, are to ensure the continued availability of outdoor recreational opportunities, to meet legal requirements for the health and safety of visitors and to mitigate conflicts with other resource use.

Most of the HMP is in the Visual Resource Management Class 3 area. The Shirley Basin area is in a $\mathrm{Class} 4$ area, and the area bordering Medicine Bow National Forest is in a Class 2 area. The Visual Resource Management objective is to minimize adverse effects on visual resources while maintaining the effectiveness of land-use allocations. The classes range from Class 1 which requires that man's influence be substantially unnoticeable to clasg 4 which allows obvious human impacts.

No site plans, interpretive programs, or managed recreational developments are existing or planned on BLM lands within the portion of the HMP that lies within the GDRA. No wilderness study areas lie within or adjacent to the HMP Area. No Special Recreation Permitees have basecamps authorized within the HMP Area.

Historic recreational use of the HMP Area has been primarily dispersed hunting and fishing. Big game herds enhance the perceived value of hunting and wildife viewing opportunities in the HMP Area. Herd gize maintenance or increages would be beneficial for these purposes.

Wheatland Reservoir $\$ 3$, roughly 30 miles north of Laramie, has been developed for recreation by the WGFD. Most of the other watersheds and waterways within the GDRA portion of the HMP have little or no legal access to adjoining public lands (see .34A.5.b).

off-road vehicle policy in the GDRA and PRRA requires motorized vehicles to stay on existing roads and trails within the HMP Area (see . 34A.5.b). Over-the-snow vehicles may be used, provided they do not adversely affect wildife or vegetation.

\section{.37D Wilderness Designation Relative to Wildlife Programs}

Wildlife populations, especially threatened and endangered species (T\&E), are a gignificant part of wilderness values. Wildiffe contributes to the perception of a place as "untrammeled" by man and strongly enhances the wilderness experience.

There are no wilderness areas or wilderness study areas within or adjacent to the HMP Area.

\section{.37E Areas of Critical Environmental Concern (ACECs)}

The Como Bluff ACEC is a National Natural Landmark managed for paleontological and historical values five (5) miles east of Medicine Bow. It does lie within the HMP Area. Map 17 shows the location of this landmark, which is on the edge of the HMP Area. There are not any plans to develop wildilfe projects within this particular area, and if this does occur a site-specific EA will be completed at that time. 
0

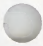

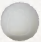




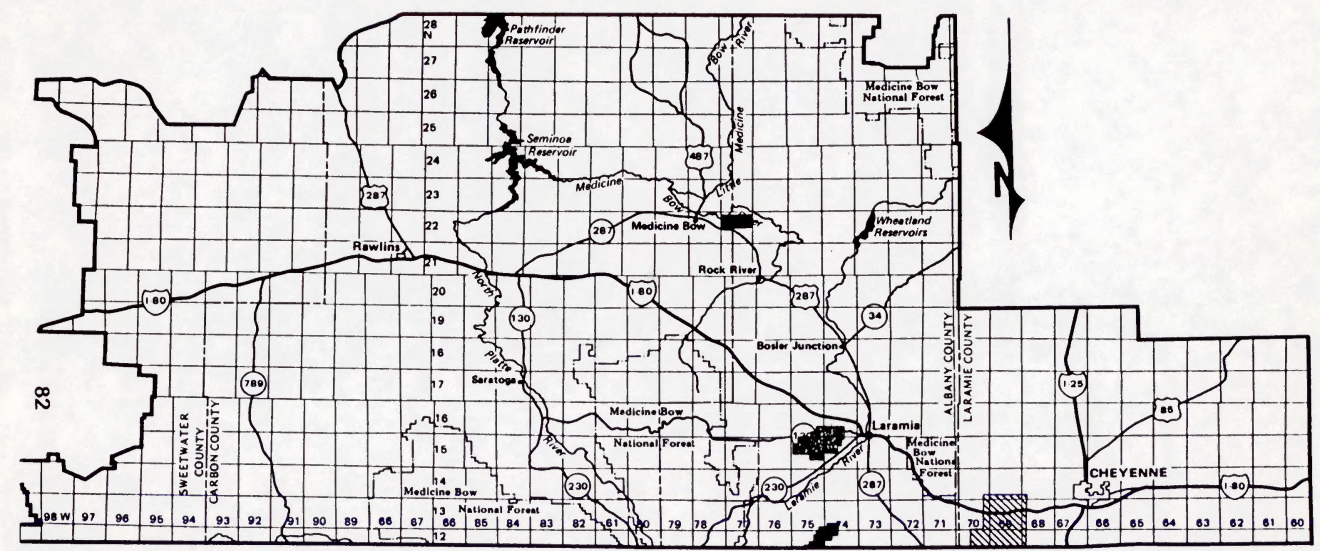

Como Bluffs

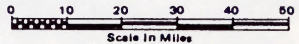

Big Hollow

Sand Creek

Gangplank (Currentiy in Nomination Process)

Note: Boundaries are illustrated precisely on

Map 17

individual land ownarship utatus maps.

GENERAL LOCATIONS OF NATIONAL NATURAL LANDMARKS Great Divide Resource Manegement Plan November, 1900 


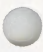

0

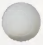




\section{.376 Wild Horse and Burro Resources in the HMP Area}

There are not any wild horses or burros presently located in the HMP Area and probably will not be any in the near future.

\section{$.37 \mathrm{H}$ Energy and Minerals Development Activities in the HMP Area}

At this time, relative to the existing energy and minerals program for BLM public lands, the Shirley Basin uranium mines are no longer operating and all of these mines are in some stage of final reclamation. Bentonite is known to occur in the Shirley Basin area, however, no known plans exist to mine the material.

Exploration for uranium is occurring to locate further uranium deposits, however, mining methods would probably be in-situ.

Sunrise Stone is producing tile rock slabs from a quarry on the Kennedy Ranch, which is located on private and State lands. The processing plant is located near wheatland, the eastern fringe of the HMP Area.

Again, there is continued reclamation processes occurring on the uranium mines. At this time, there is no known mineral activity planned in the HMP Area.

\section{.37 I Fire Management Program Relative to Habitat objectives}

The Laramie Range has been protected from fire for several decades. Logging has been limited to areas of easy access and high timber quality. As a result, parts of the sheep range have succeeded towards a timber-dominated climax species that appears to be segmenting the sheep population. Since there have not been many fires in general, and logging is not evident in many areas, the sheep herds are becoming fragmented and isolated. A mountain pine beetle epidemic has occurred throughout the HMP Area resulting in conditions favorable to large wildfires.

A wildfire in October 1974 south of Split Rock and Duck Creek (T. 24 N., R. 71 w., Sec. 3) burned approximately 3,100 acres before it was contained. The fire removed some of the timber canopy, suppressed the succession towards conifers, and stimulated forage on both the summer and winter range. Bighorn sheep were using the burned area extensively within a few months. That burn continues to draw bighorn sheep, as well as deer and elk, to the area and is basically the natural ecosystem platform that this HMP and associated EAs is trying to accomplish. Wildfires, if extremely large, can often cause extensive habitat losses to wildlife, but if smaller or controlled fires occur, then often these losses are reduced to favorable conditions and results. There is such a vast amount of beetle-kill among the forests in the HMP Area, that if and when a wildfire occurs, at this time, it will probably be extremely drastic and large. In this event, it may cause severe soil and vegetation scarring and damage beyond natural conditions.

In 1986, two (2) large fires occurred near Collins Peak and Three Cripples Creek, both located in the HMP Area. Both fires removed extensive areas of ponderosa pine forest near rugged escape habitat. Additional fires have burned in Government Peak, Duck Creek, Bearhead Mountain and Sheep Mountain. The areas where fires have occurred are utilized by bighorn sheep and other wildife for foraging, nesting, parturition, and resting activities.

The Split Rock Prescribed Burn (see Appendix $X$ ) is basically similar to fires that the agencies involved are trying to achieve to improve habitat for bighorn sheep. Since there are many large stands of diseased conifer stands that will naturally burn (although some may take $100+$ years to do so) it is possible to "assist" nature and prescribe burn these areas in the near future for bighorn sheep herds. The major problem that the BLM agency faces is the danger, difficult terrain, unpredictable weather patterns, and changing attitudes of the Washington office when it comes to burns on the mountains. Windows are difficult to reach, therefore other projects to improve habitats must be planned in addition to ensure overall success of the HMP project. 


\section{$.37 \mathrm{~J}$ Archeology/Paleontology Actlvitleg Relat lve to Wildilfe}

The management objectives for these resources in the GDRA and PRRA are to protect and preserve representative samples of the full array of cultural resources for the benefit of scientific and socio-cultural use by present and future generations. These resources are non-renewable and any activity that occurs at the individual proposed project areas will be assessed for such resources at the EA level. The GDRA RMP also ensures that cultural resources are given full consideration in all land-use planning and management decisions. Cultural clearances will be completed on a site-specific basis for each BA so that the BLM personnel can manage cultural resources so that scientiflc and socio-cultural values are not diminished, but rather are maintained and enhanced. It is critical that any activity in the Laramie Peak HMP Area and associated proposed projects avold inadvertent damage to cultural resources both federal and nonfederal.

The BLM will conduct Class I, II, or III inventories for actions involving BLM administered public land and/or federal minerals that include surface disturbance as part of the action. At this time, there are not any plans for mineral development in the area (see.37H) to occur, however, if it does occur, then cultural clearances must be completed for the area.

The BLM will aloo evaluate the gigniflcance of cultural resources identified in consultation with the Wyoming state Historic Preservation office to determine whether the resources are eligible for inclusion on the National Register of Historic Places.

The BLM will categorize cultural resources for management purposes (e.g. public use, scientific, socio-economic) for each proposed project at the EA level.

The above actions will be carried out for each site-specific action (15 total) in accordance with law, policy, and guidance to meet the objectives for cultural resources management. 


\section{$.37 \mathrm{~K}$ Support Activities Relative to Implementing the HMP}

These activities involve the subactivity needs of the BLM agency for cadastral surveys; road, trail and building construction; and land easement acquisitions. These activities support the HMP implementation, however, due to the size and nature of this particular HMP, they will have to be planned, implemented and monitored at the individual project proposal (e.g 15 total sites) EA level. At this level, the support needs in terms of FYs, dollars, and workmonths will be stated. This process at the EA level will serve as a budgetary vehicle to obtain funds for support activities. Any land and realty actions that are needed, including acquisitions (exchange or other acquisition authority) or protective withdrawals, agencies and private parties involved, locations, and time frames will be discussed at the site-specific proposed project EA level.

\section{$.37 \mathrm{~L}$ Other Areas of Coordination Required to Implement the HMP}

Any areas of coordination or actions needed which are not covered above and which specify particular directives, uncodified rules, or restrictions will be addressed at the individual site-specific proposed project EA. Any restrictions which are authorized by regulation and require public notice (i.e. ORV closures, firearms restrictions, use of fires) that require Federal Register notice will be implemented at the EA level.

Any coordination with other agencies, environmental groups, interested parties, and the general public will be done at the EA level for each proposed project area. There has been coordination with the USFS, BLM, and WGFD for the planning of this document and there will be additional coordination for the implementation and monitoring as well.

Consultation for threatened and endangered ( $T / E$ ) species has been informally done between the BLM and the USFWS in Cheyenne, Wyoming. A copy of that informal consultation can be located in Appendix III. At this time, personnel from the USFWS believe that it is more prudent and accurate to have informal/formal $T / E$ consultations at the individual EA level for each proposed site-gpecific habitat improvement area. Since this HMP is an extended document (10-15 years) and is vast in scope it will be scientifically more accurate to assess any $T / E$ species when individual EAs are planned.

Opertations that fall on the U.S. Foregt Service Lands will comply with the USFS standards and guidelines found within the Medicine Bow National Forest Land and Resource Management Plan, presently in pre-draft stage. The agency is currently operating under the 1985 plan (refer to page 25).

Coordination with the Wyoming Game and Fish Department will occur utilizing the Sikes Act Authority as outlined on page 25 . 
0

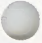

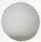




\section{$.37 \mathrm{~K}$ Support Actlvities Relative to Implementing the HMP}

These activities involve the subactivity needs of the BLM agency for cadastral surveys; road, trail and building construction; and land easement acquisitions. These activities support the HMP implementation, however, due to the size and nature of this particular HMP, they will have to be planned, implemented and monitored at the individual project proposal (e.g 15 total sites) EA level. At this level, the support needs in terms of FYs, dollars, and workmonths will be stated. This process at the EA level will serve as a budgetary vehicle to obtain funds for support activities. Any land and realty actions that are needed, including acquisitions (exchange or other acquisition authority) or protective withdrawals, agencies and private parties involved, locations, and time frames will be discussed at the site-specific proposed project EA level.

\section{$.37 \mathrm{~L}$ Other Areas of Coordination Required to Implement the HMP}

Any areas of coordination or actions needed which are not covered above and which specify particular directives, uncodified rules, or restrictions will be addressed at the individual site-specific proposed project EA. Any restrictions which are authorized by regulation and require public notice (i.e. ORV closures, firearms restrictions, use of fires) that require Federal Reqister notice will be implemented at the EA level.

Any coordination with other agencies, environmental groups, interested parties, and the general public will be done at the EA level for each proposed project area. There has been coordination with the USFS, BLM, and WGFD for the planning of this document and there will be additional coordination for the implementation and monitoring as well.

Consultation for threatened and endangered (T/E) species has been informally done between the BLM and the USFWS in Cheyenne, Wyoming. A copy of that informal consultation can be located in Appendix III. At this time, personnel from the USFWS believe that it is more prudent and accurate to have informal/formal $\mathrm{T} / \mathrm{E}$ consultations at the individual EA level for each proposed site-specific habitat improvement area. Since this HMP is an extended document (10-15 years) and is vast in scope it will be scientifically more accurate to assess any $\mathrm{T} / \mathrm{E}$ species when individual EAs are planned.

$*$

Operations that lael on USFS lands will comply wiri USFS Standands and Guidelines fourd within the

Medicune Bow National Forest land and Resounce Management Plaw, presently in pre-draft stage. Opuating under the 1985 plan. (Refer to page 25).

1 Complicts wlexisting WGFD land use documents. (List areas)
Suct a: 


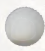

0

O 
The Laramie Peak HMP must repressnt either the least costly approach for accomplishing precisely specifled objectives (e.g. improve/increase bighorn sheep populations in the Laramie Range) or the most beneficlal approach to solving the general problems or goals identified in the HMP. There are both priced and nonpriced accomplishments that can be analyzed for the HMP, but to utilize the best available data and considering the overall time constraints of the 15 individual projects, these factors should be analyzed on a site-by-site basis. The general HMP objectives will benefit soclety on an intrinsic value since the profects will increase bighorn sheep and other wildilfe populations as a whole.

Tangible benefits can be calculated on a yearly basis using the wGP procedure for calculating recreation days/hunter success rates for the big game populations In the Laramie Peak HMP Area. Intangible benefitg can be derived both directly and Indirectly from the objectives of the 15 individual site-specific projects. Prescribed burns and small commercial logging practices can improve the quality and quantity of required vegetation and foraging areas for bighorn sheep and other wildiffe populations. Fence modifications can restrict some cattle use thereby maintaining and improving riparian communities. Improved riparian conditions will increase the avallabllity of more palatable and desirable forage species for cattle and big game animals. Aquatic/wetland, riparian and reservolr improvements will increase desired vegetation for wildilfe, improve water quality, and offset the adverse effects of drought and severe winter weather on the stability of big game populations. These cumulative conditions which will lead to increased fisheries and other wildlife habitat uses, improved water quantity and quality, increased and improved wildlife diversity (species richness and evenness), increased and more productive use of the Laramie Peak HMP Area natural resources.

\section{.38A Methods}

Benefits for individual project proposals (15) will be based on an analysis of wildife and fisheries productivity with and without the plan, specifically bighorn sheep. The purpose of the wildilfe and fisheries productivity analysis is to estimate the increase or decrease in the numbers of a particular species (particularly bighorn sheep) that occur as a direct, indirect, and cumulative result of the 15 proposed projects. In this situation, the least-cost analysis should be used since the principle benefits (improved wildlife habitats) of the HMP can be estimated in biological terms versus monetary terms. Otilizing this concept, Individual EAs for each proposed project will demonstrate that alternatives have been examined for achieving-site-specific objectives and that the recommended alternative for each EA is the least costly alternative considered. Benefit/cost analysis are usually used when the benefits can be measured in monetary terms, which, under these particular circumstances is not a viable approach.

The BLY office does maintain 1 ts estimates of the value of fish and wildife recreation in the BLM price file. These filles are usually maintained at the state office and can be utilized on a case-by-case basis for each proposed project. An analyses for each project will be completed at the EA level since some of these EAs may not be started for several years and economics are so dynamic.

The BLM subscribes to the willingness-to-pay theory of wildilfe valuation. That is, a user day of wildlife recreation is worth what the user would pay if an access fee were charged for the recreation. The principle methods for estimating willingness to pay are the travel cost demand method, the contingent value survey method, and the market appraisal method. Where functioning markets exist for fish and wildife as in commercial flshing, fur trapping, and pay hunting, market prices may be used as the value of wildife. Since these markets are changing on a dally basis, an analysis using the Wildlife Economics and Productivity Analysis Guidebook, a method that follows the BLA's policy for wildiffe economics 
0

0

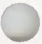


and which is avallable at the GDRA office, will be used for each alte-specific proposed project $8 A$ (15 total).

If an EA is utilizing the least-cost analysis for wildlife habitat improvement, it does not have to include a list of prices for the benefits. In addition, when analyzing non-priced effects on fish and wildife productivity, for example that which protects populations of threatened and endangered species, the least-cost analysis approach can be used.

When management objectives concern priced and non-priced wildlife, a benefit/cost analysis can be applied to the priced outputs or effects of the management plan (e.g. Individual project EAs). The non-priced outputs can be addressed as additional evaluation factors to be considered in evaluating and ranking projects or plans. The procedure for evaluating priced and non-priced outputs, which will be used at the EA level, can be found in the BLM Handbook $H-1740-1$, Chapter 6 , which can be located at the GDRA office. The non-priced factors which are used are listed in section. 06B of the Handbook.

\section{$.38 \mathrm{~B}$ Sources of Information}

Each of the fifteen (15) individual proposed project EAs will summarize data relevant to consumptive and nonconsumptive uses of the wildlife sources (e.g game harvest, hunter and fish person days, sport and comercial fisheries harvest). Information that will be developed within the EAB will also be coordinated with the BLM State and/or District Recreation Planners. The WGFD, USFS, PRRA BLM, and USFWS will be consulted for all relevant figh and wildlife harvest and other wildlife use data for each EA. Migratory wildife species (e.g. neotropical migratory birds, bats) will also be considered. There are available sources of information that can be used at the EA level; the National Survey of Fishing and Hunting provides information on consumptive and non-consumptive use of wildlife on Federal lands, as well as private organizations and individuals that are knowledgeable in the field. 
0

0

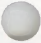




\section{.39A Program coordination}

A comprehensive public affairs action program with BLM District/state office staff personnel will be written and implemented for each individual eite-epecific project proposal (15 total) for the Laramie Peak HMP Area. Table 2 deplcte the general information procedures that will be executed for each project and associated activities and completion dates. The Split Rock Project Proposal has been completed (BLM EA WY-037-EAO-038) and can be used as an example of the different forms of public awareness activitieg that will be implemented for each proposed profect. At a minimum the public affairs program will include funds, personnel, equipment, and required activity needs for printing, publication, and distribution, entrance signs for the area and signs to explain on-the-ground activities; public land ldentification and property lines; slide shows, movies, tapes, and recordings; brochures, leaflets; graphics; and cartography.

\section{.39B Distribution}

Copies of the Laramie Peak HMP and associated EA, as well as the EAs for the individual project proposals will be distributed to cooperating federal and state agencies (such as the WGFD, USFS), environmental groups, local agencies, and interested parties of the general public. In accordance with Section 201 of the FLPMA of 1976, amended 1987 (43 U.S.C. 1711) the public land boundaries for each proposed project site will be determined and identified with signs and maps as a technique in achleving public awareness and support. Information brochures (e.g. benefits to specific wildlife species and habitats, rules and regulations pertalning to restriction of public activities in the EA area) focusing on the overall benefita derived from each project activity can be prepared for public distribution upon the implementation of each proposed project EA. 


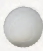

0

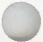




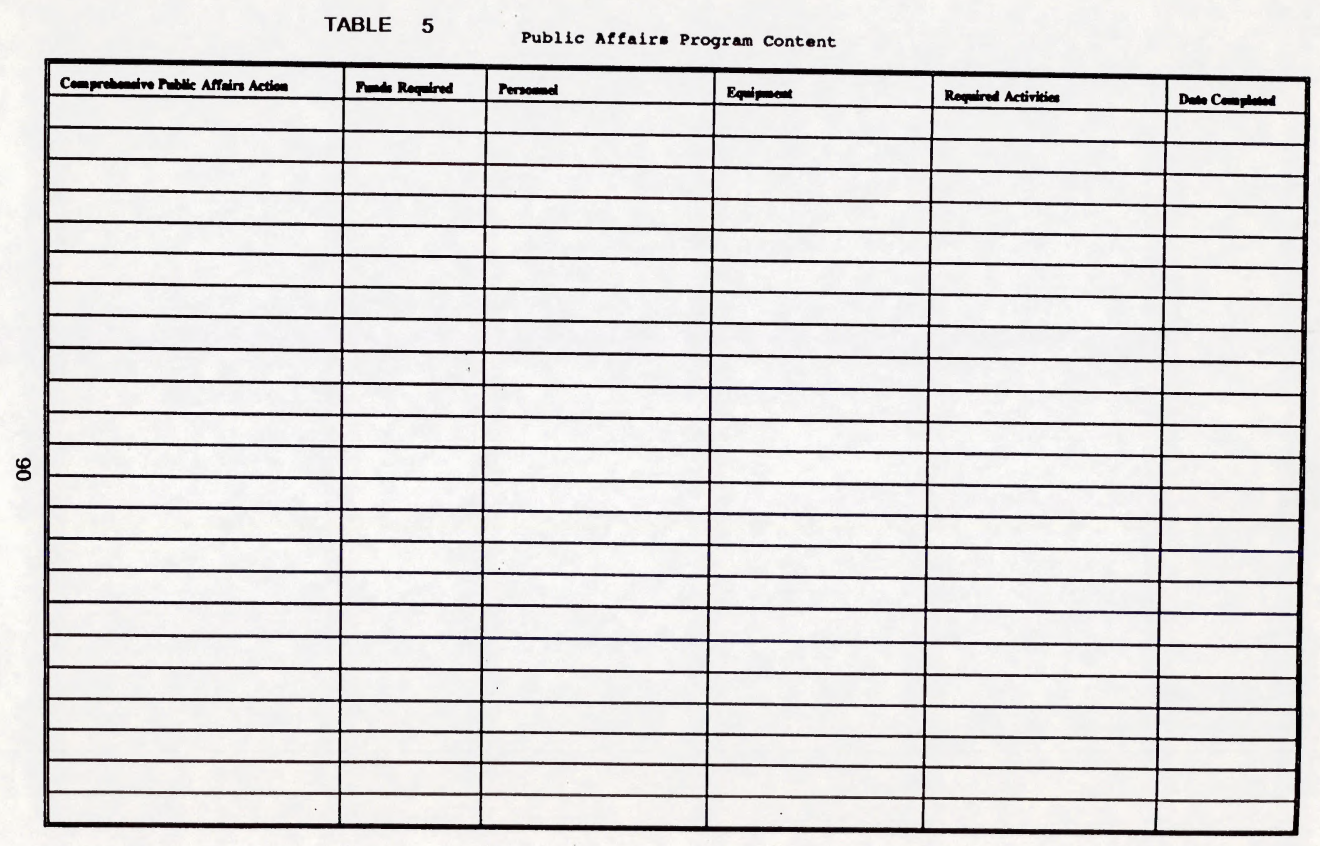


0

0

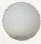


The Laramle Peak HMP contains 15 ite-specific project proposals that will be assessed and analyzed on a case-by-case basis utilizing individual BAs. Table 6 provides an estimate of the funds, personnel, equipment, and procurement needs for the entire HMP project in general (over a 10-15 year time pan). Tablea 7-21 provide estimates of the funds, personnel, equipment, and procurement needs for individual project proposals. Since many of these activities may not occur in the immediate future, there will be numerous revisions required to accommodate shifting economic circumstances. The data on this form can assist in determining needs through the AWP and FLMA 4-Year Authorization for the wildilfe subactivity and assoclated support activities. 
0

0

0 
UNITED STATES

DEPARTMENT OR THE IMTERIOR

BUREAU OF LAND MANACERENT
Stata

Dietriet

Rasourca Area

Name of HAP

FY Prepared

FORMAT FOR SURARY OF HABITAT MANAGEMENT PLAN DEVELOPHENT COSTS

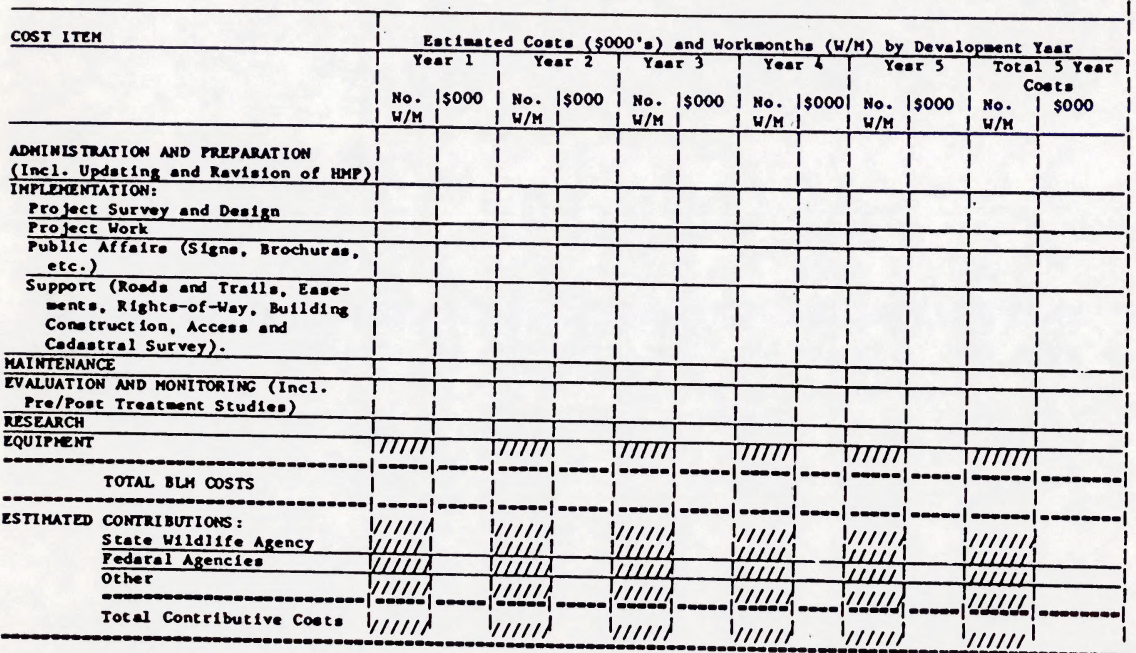


0

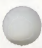

0 
UnITe states

DEPANTnewr or THE ImTEx on

ourav of LAND MuNucerert state Wyamina

Dietrice Gowlity

Recource Aree crestsinth BA

Nene of RHP Langmishek/FY Propered

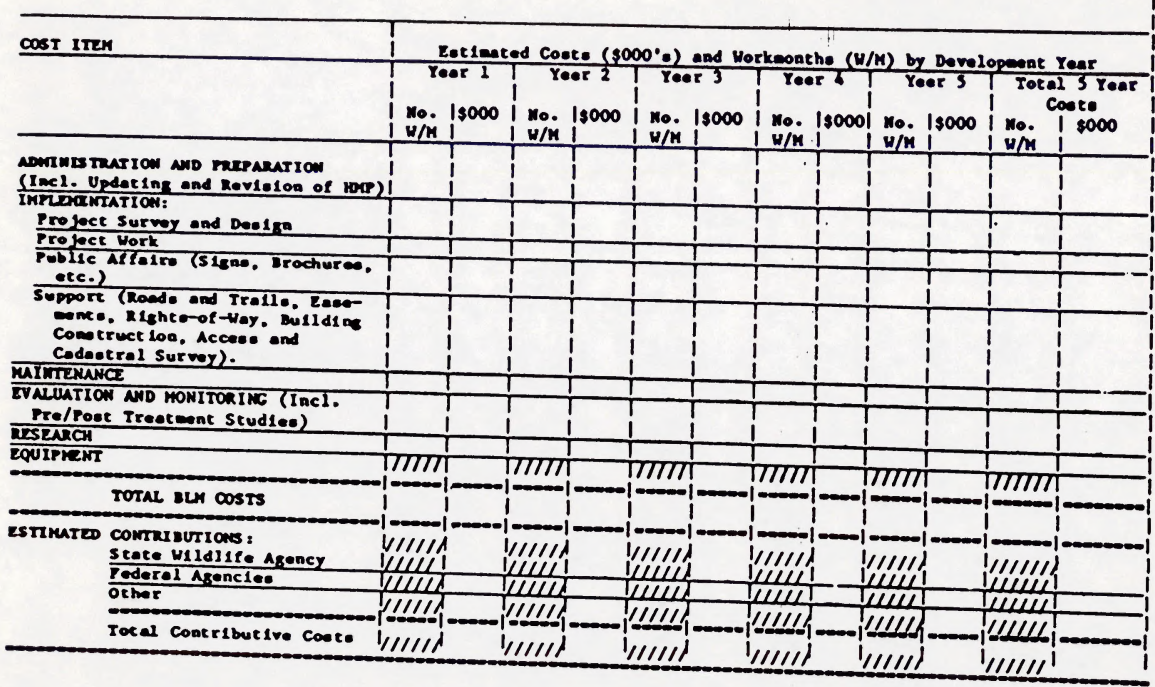


0

0

0 
UNITI STATES

DEPANTERT OF THE IMTERI ON

wreal or LAND Muruceerst state Wyoming

Diecrice fhming

Resource Aree Grest rivith

New of BAPLanomie Pelk/FY Propared

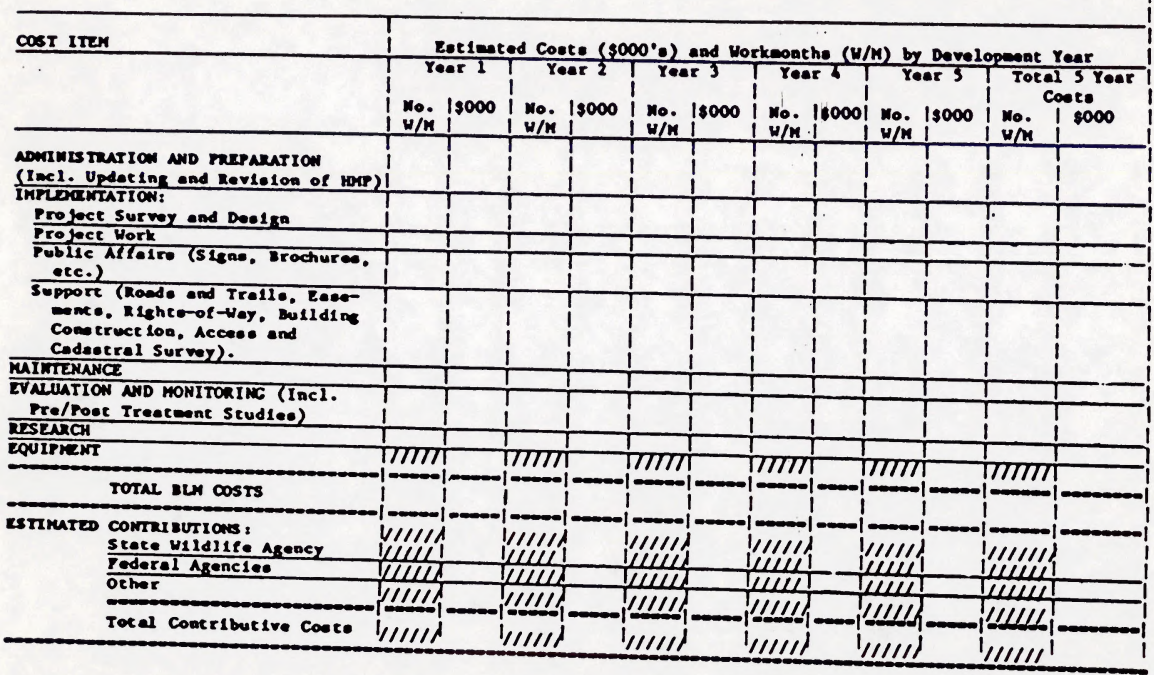




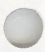

0

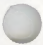


stete Wysming

Dietrict

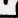

Resource Area

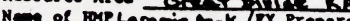

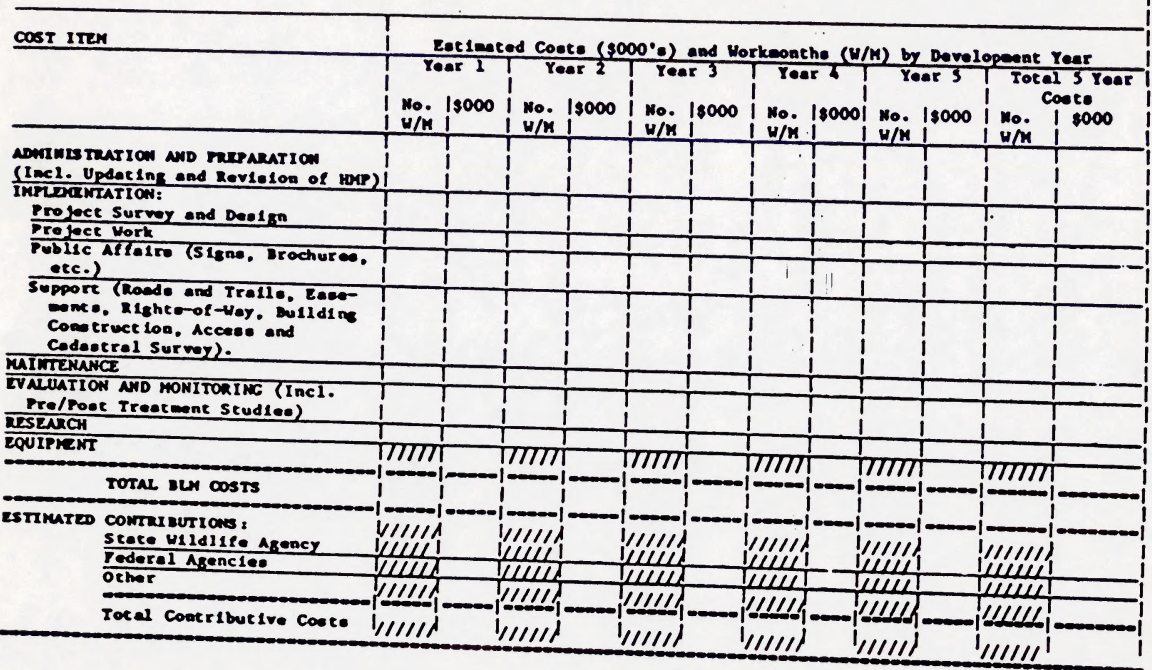


0

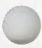

0 
UNITED STATES

DEPAKMENT OF THE IMTERIOR

wrend of LAND muncerent stete Wyrming

andling

Recource Area coent simils BA

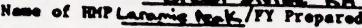

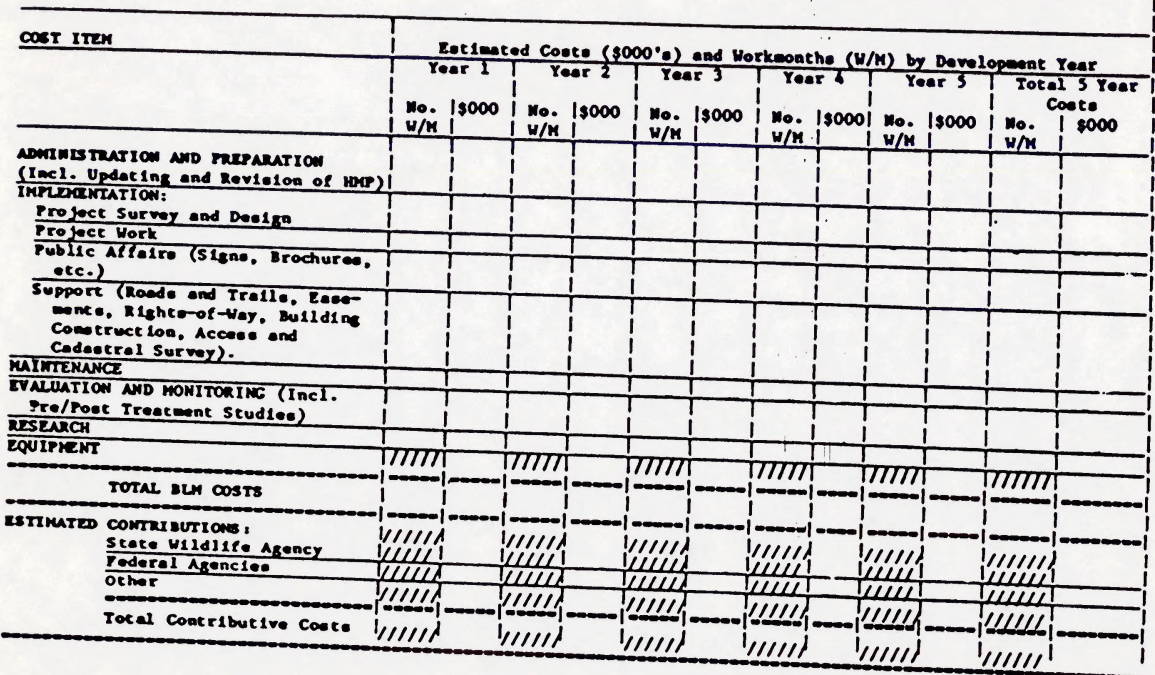


0

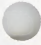

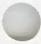




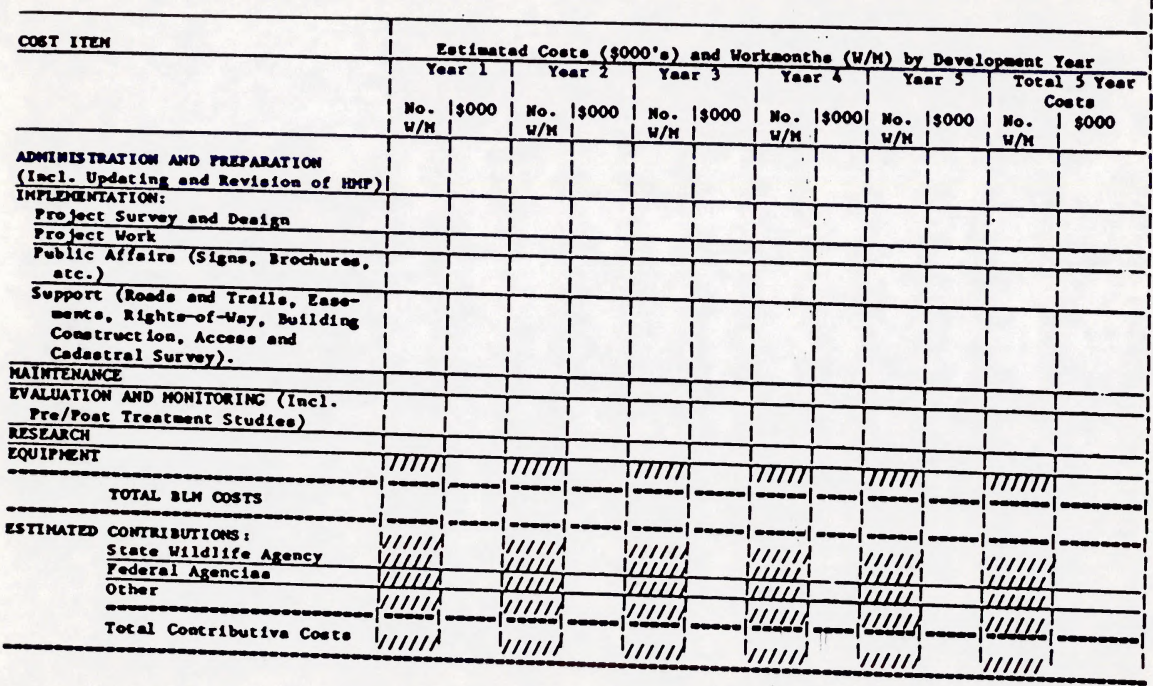


0

0

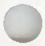


UNITE STATES

DEPATMENT OS THE IMTERI OR

cunced or LAND MaNucerert scere Wyoming 3 . andives

rivit. SA

Now of RMP Lenemie NeK/FY Propered

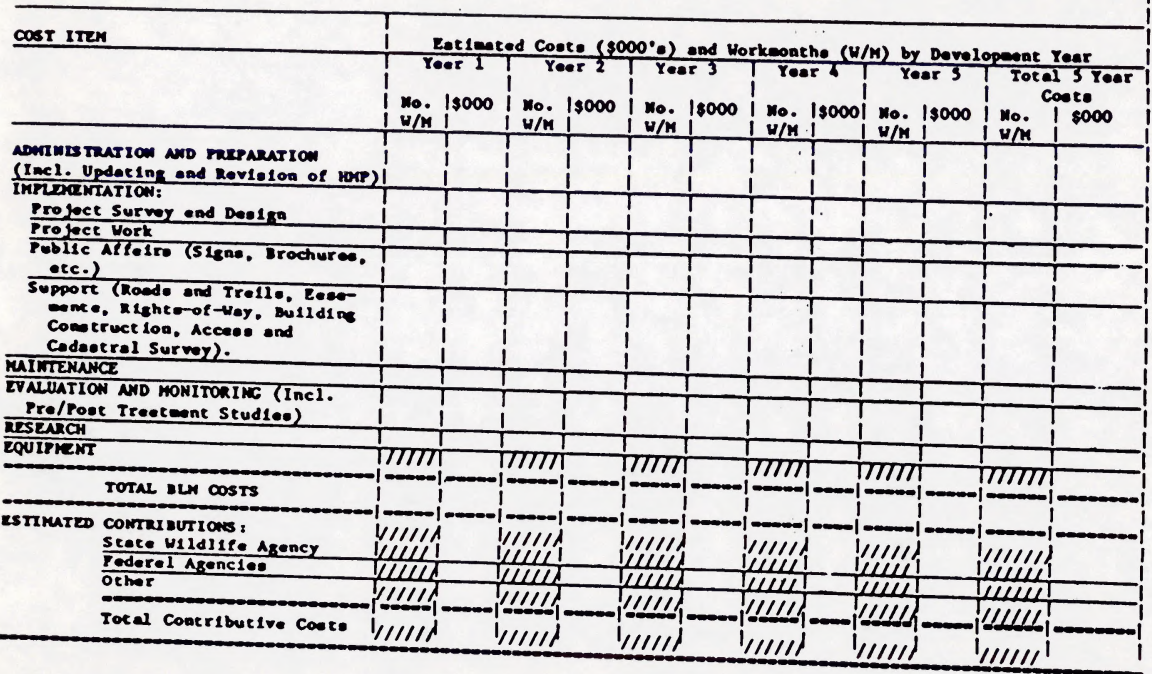


0

0

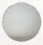


stece Wyomine

Dietrict fomblins

Resource Aree

Romalive

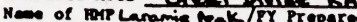

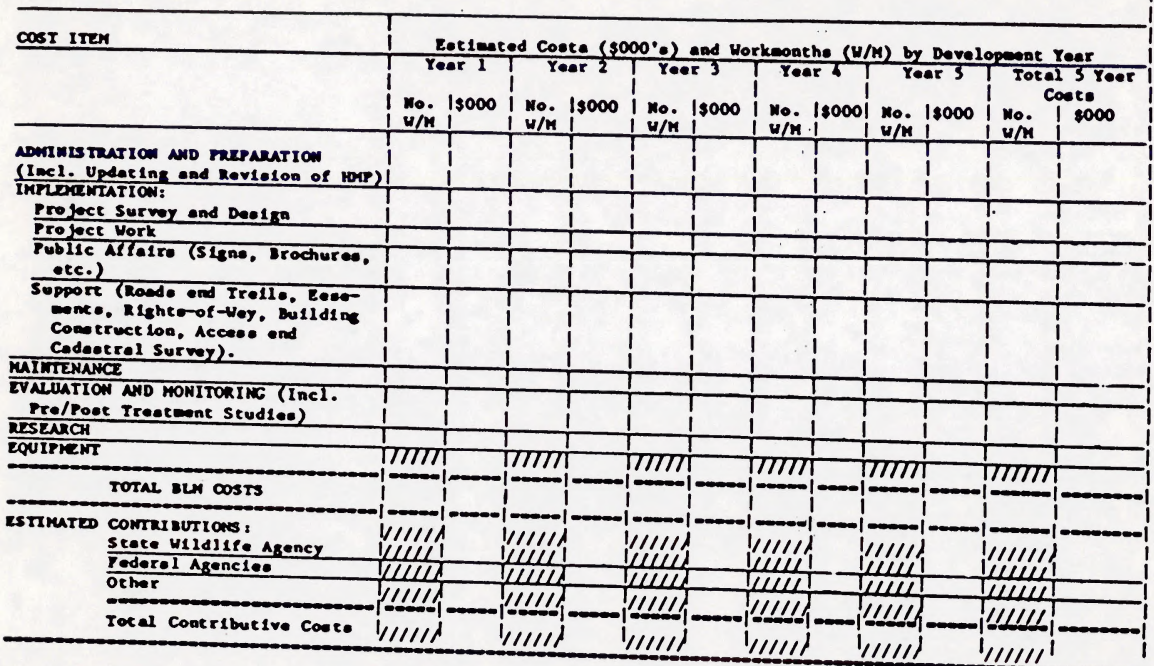


0

0

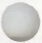


UNITED STATES

DZPANTECMT OF THE INTERI OA

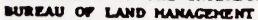

seate

Wretromine

Romalins

Resource Aree cons Tinile BA

Nene of FAP Lañamis trek/FY Prepered

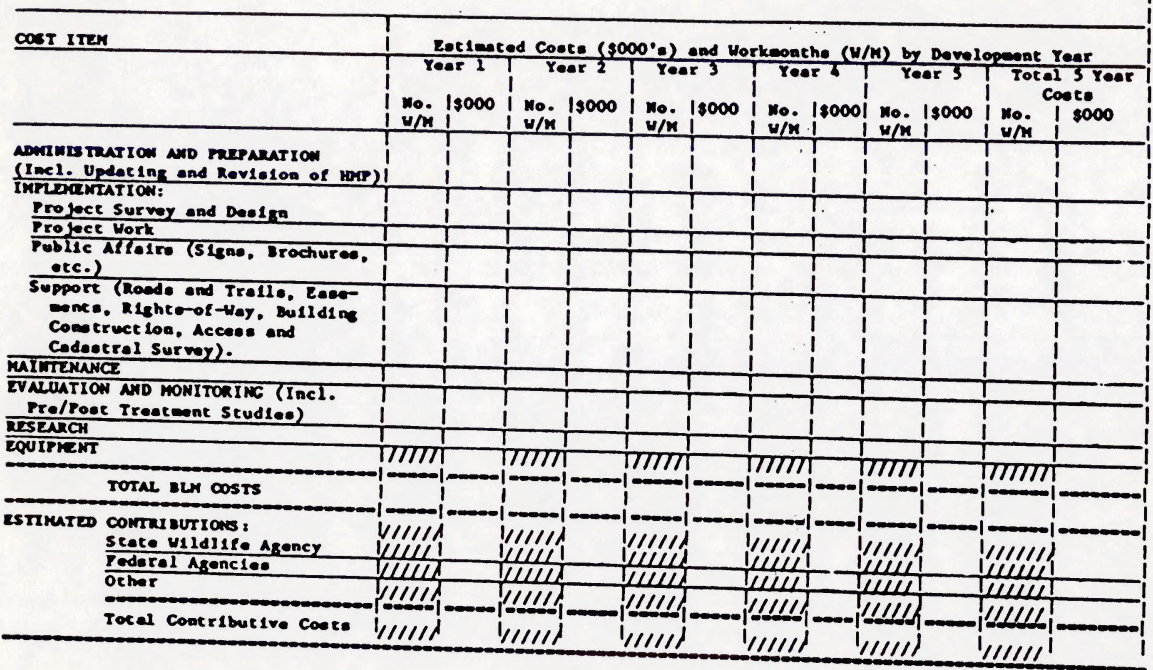


0

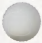

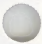


UNITS STATS

DEPAKTREMT OF THE IMTERIOR

whead or LAND Mavuceers stete Wyoming

Recource Aree

Somalive

Areo cont rivile BA

Nees of BMP Lañan toek /FY Propared

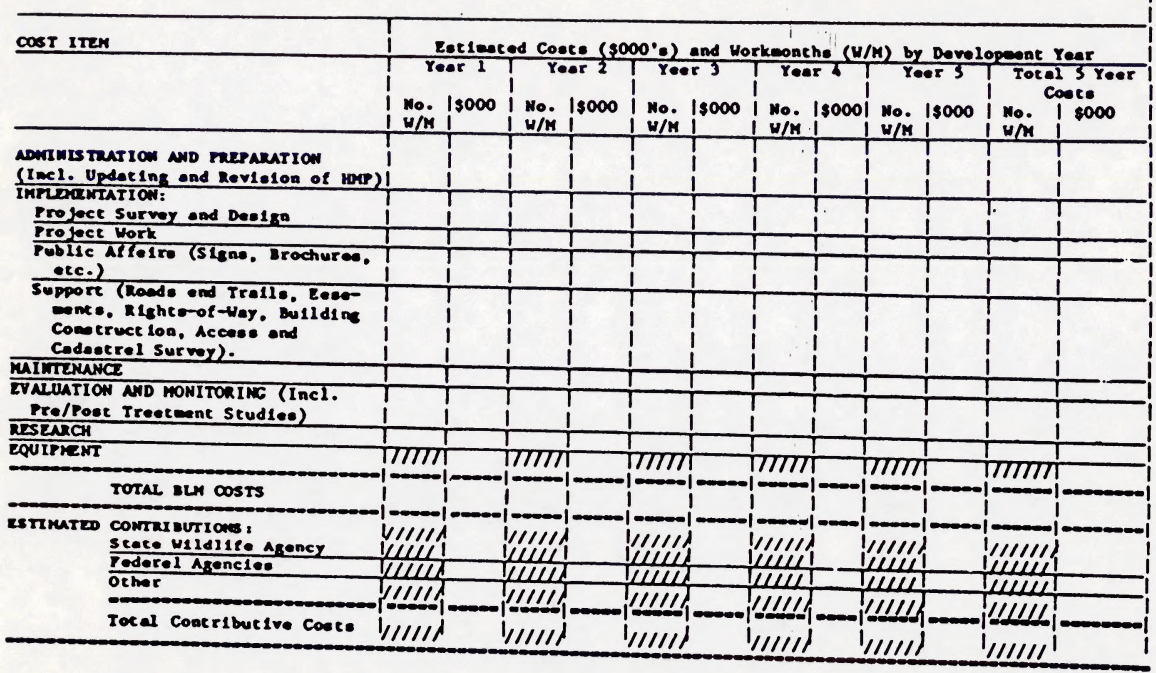




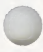

0

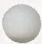


UNITED STATES

DEPATMEST O THE IMTERI OA

vereal of LAND Munceatem state Wyaming

Dietrice thewling

Recource Aree

onding

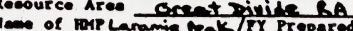

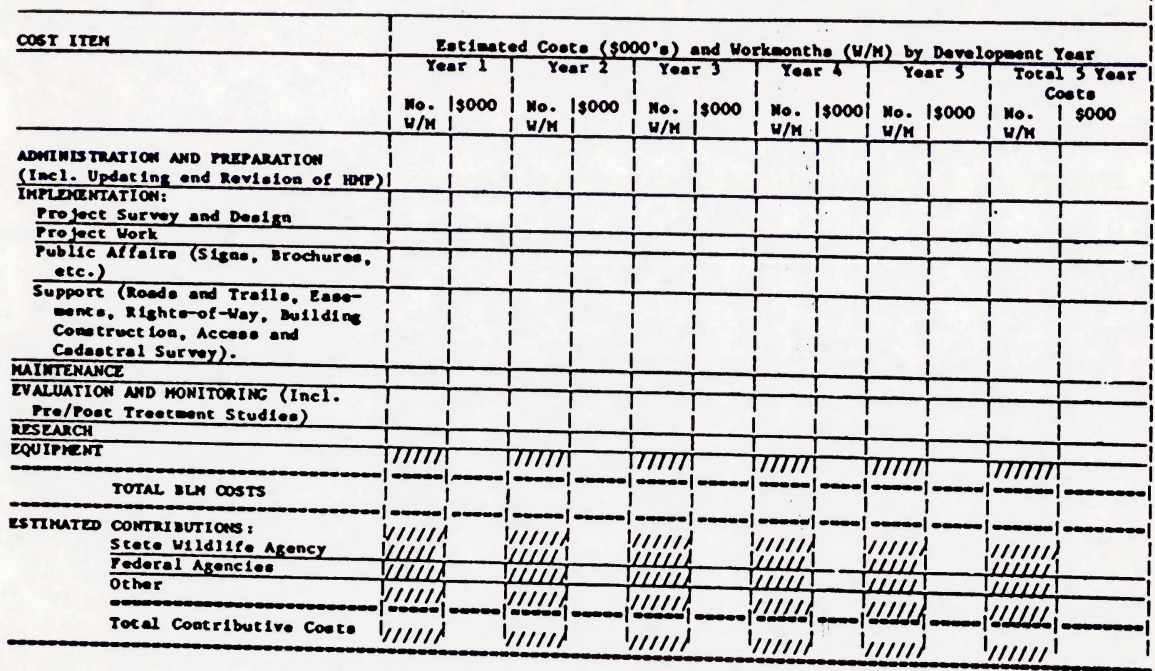


0

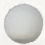

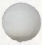


UNITED STATES

DEPATMENT O THE IMTEN ON

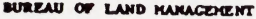

scete Wyomina

Dietrice houlin

Reeource Aree coest givite MA

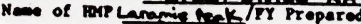

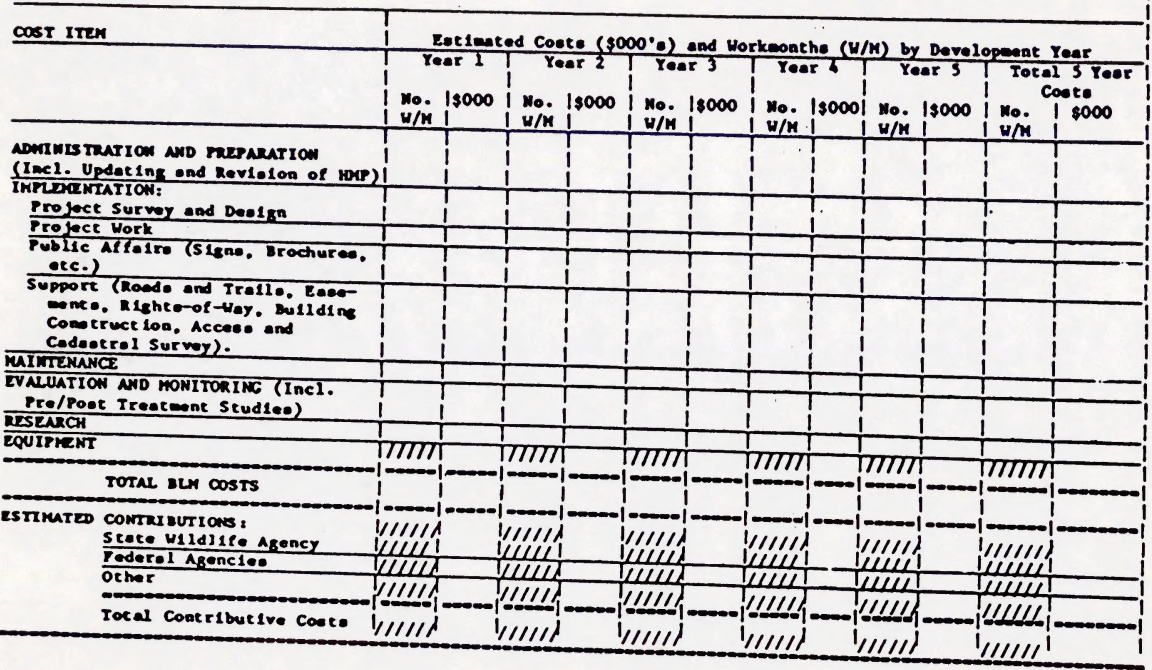


0

0

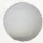


UNITE STATES

Deparmest of The ImTERion

wheno or LAND murucerers state

Wyyomine

hambling

Recource Aree crentsilite BA

New of BAP Lanomir Nak /FY Propered

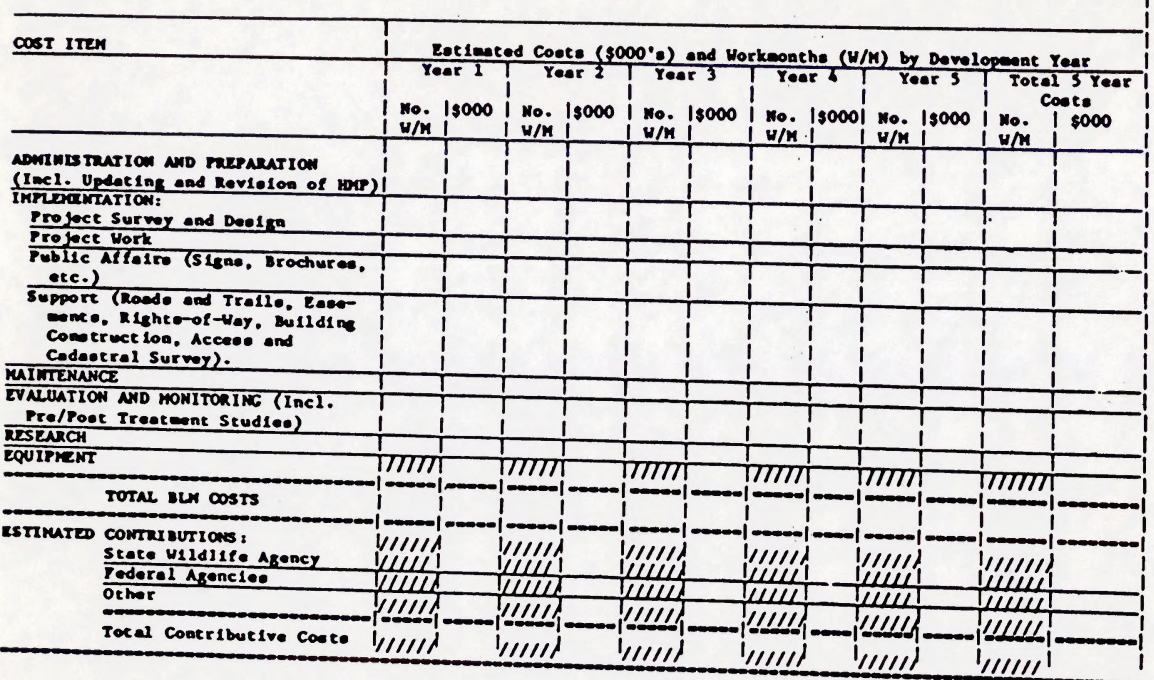


0

0

0 


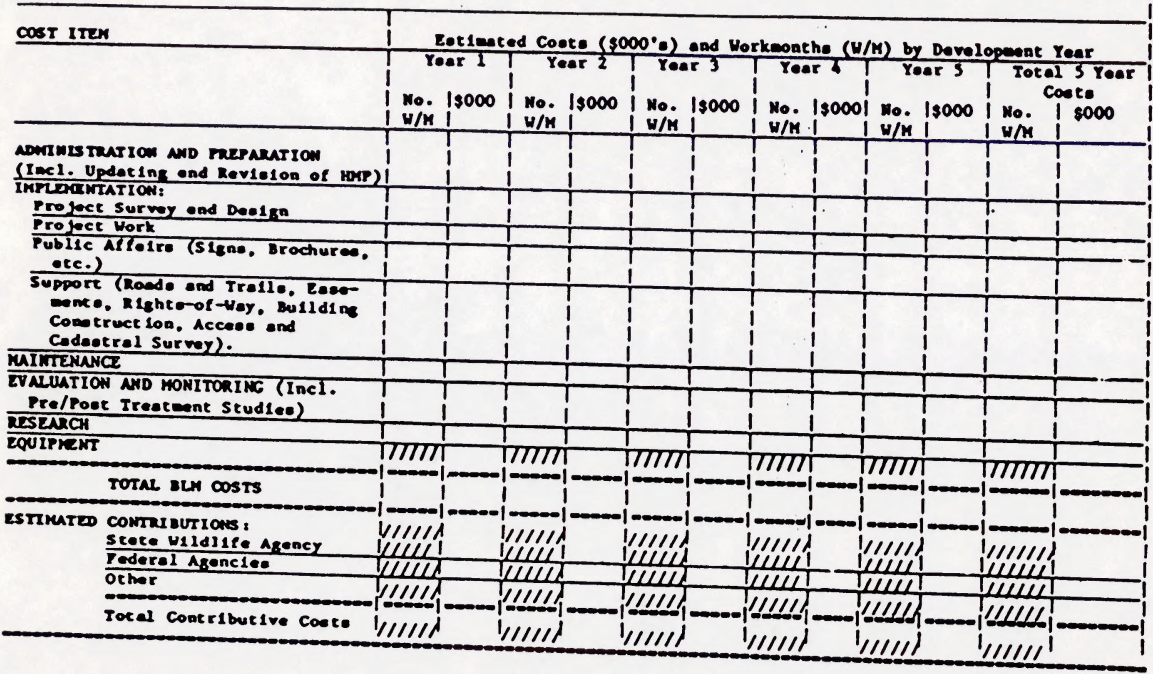


0

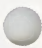

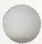


UNITED STATES

DEPANTAET OR THE INTERI OR

bureal or LAND Muncerent stece Wyoming

Dletrice fomilim

Reeource Area chent rivile GA

Hea of MAPLaramis NeK /FY Prepared

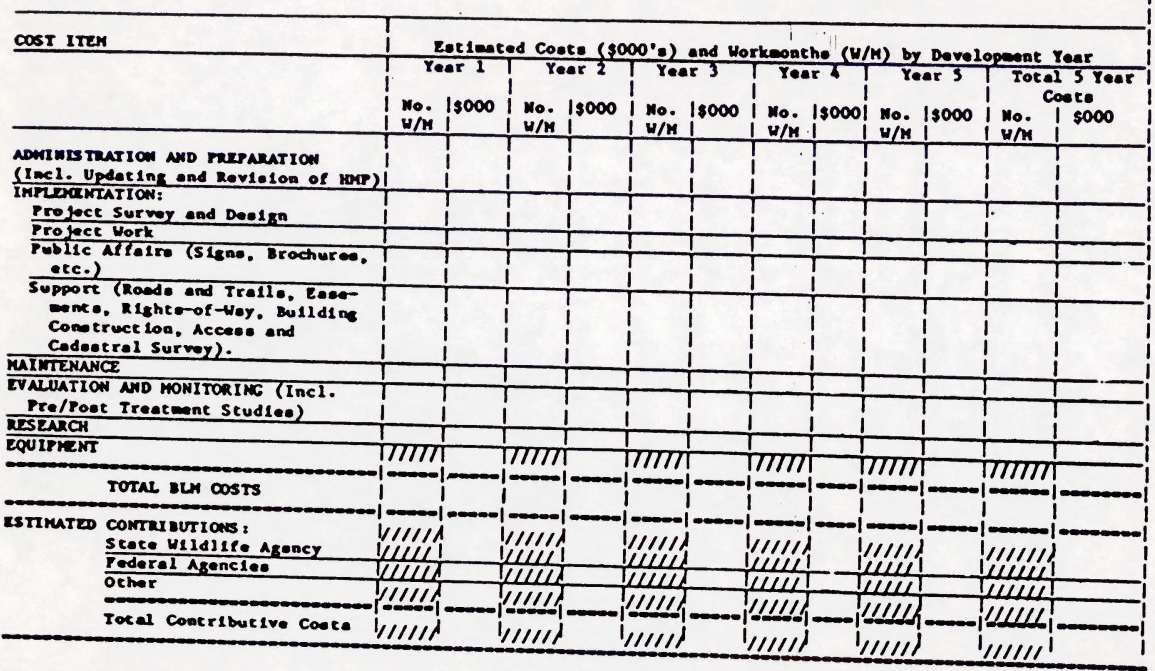


0

0

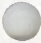


UNITED STATES

DEPANTAET OO THE IMTERI OR

wireav of Lawd Makncerem state Wyymina

Diecrice Rowaling

Reeource Aree Grentsilite BA

Newe of PHP Leromin ArKK/FY Prepared

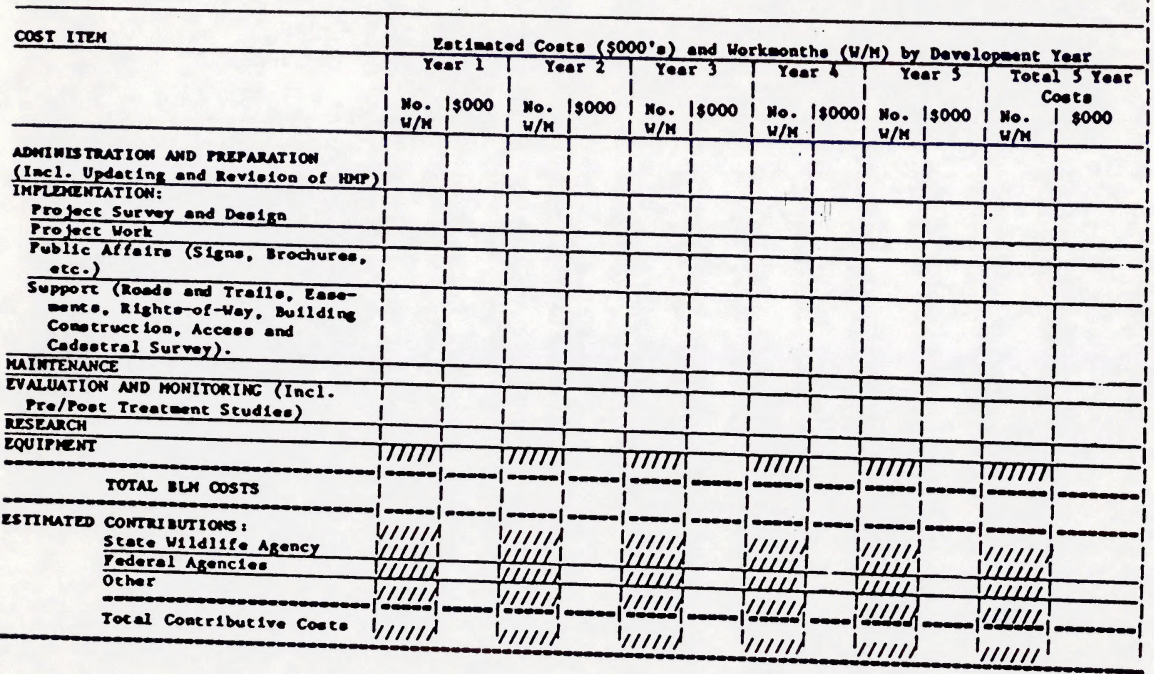




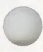

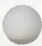

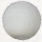




\section{$.41 \mathrm{~A}$ BLM}

The Rawlins District Manager and the Casper District Manager must sign and approve the Laramie Peak HMP upon completion and ensure that the requirements for the Great Divide Resource Area Resource Management Plan objectives and decisions are met. They also must ensure that the HMP statistics (see Table 22) are submitted to the Wyoming State office, State Director after the plan has been implemented. At the option of the Wyoming State Director, a special memorandum of understanding with the Wyoming Game and Fish Department and the USFS can be prepared to specify responsibilities, cost sharing, maintenance, and other items. Upon completion of parts of or the entire plan, the required information must be listed on HMP Statistics Form 6780-3 (see Table 22). It should be noted that since this particular HMP is so vast in nature and size it will probably not be fully completed until 2009-2010. Individual progress reports and statistical summaries will be recorded for each site-specific area in Table 2 upon completion.

\section{State Agencies and Others}

Signatures of the authorized Forest Supervisor of the U.S. Forest Service and the Director of the Wyoming Game and Fish Department (see Signature Pages) must be obtained to implement the Laramie Peak HMP and associated fifteen project proposals. This HMP is consistent with the BLM Master Memorandum of Understanding and is applicable with the Sikes Act Supplement (see.31D). Since there have already been approved and signed Sikes Act HMPs within the state of Wyoming, this particular HMP (as a subsequent HMP) may be approved and signed by the BLM Rawlins District Manager and local authorized State and Federal officials (e.g. WGFD and USFS). A copy of the HMP for which funds have been requested for implementation may be sent to the Director (240) for information and backup to
AWP preparation. 
0

0

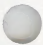


Uwren STATES

DEPARTMENT ON THE IMTERIOR

DUReav or Lamo mamacermet

mLoure MABITAT MAMAGEMENT MAN STATISTIC

TABLE 22
|

then

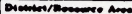

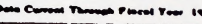
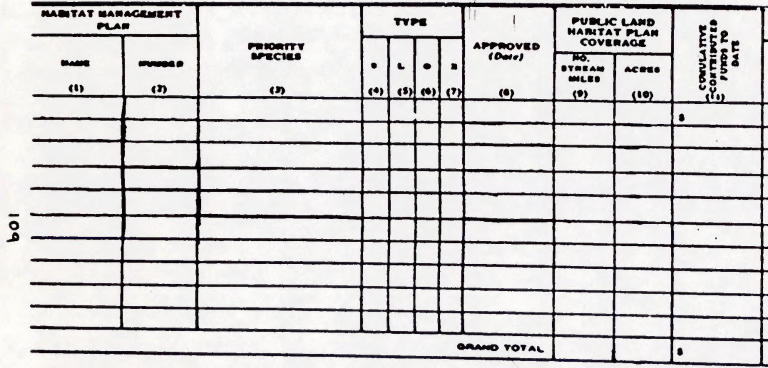

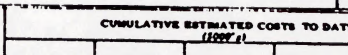

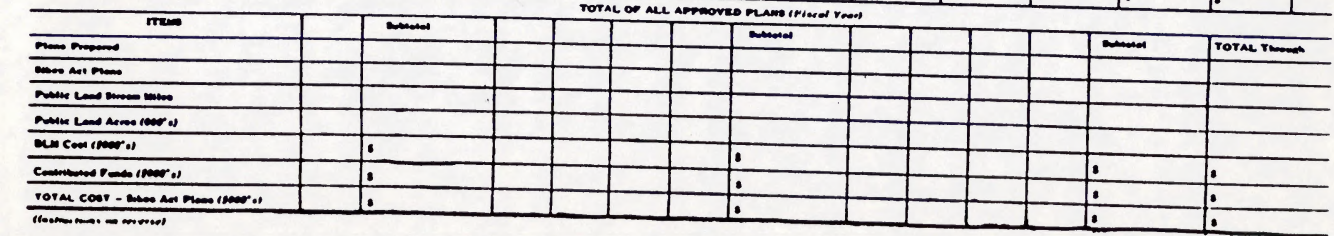


0

0

0 


\section{REFERENCES}

Baxter, George T. and Michael Stone. 1980. Amphibians and Reptiles of Wyoming. Wyoming Game and Fish Department. Cheyenne, Wyoming.

Cooperrider, A.Y., R.J. Boyd, and H.R. Stuart, eds. 1986. Inventory and Monitoring of Wildlife Habitat. U.S. Department of Inter., Bur. Land Manage. Service Center. Denver, co xviii. p. 551-556.

Hengel, D.A., S.H. Anderson and W.G. Hepworth. 1993. Population Dynamics, Seasonal Distribution and Movement Patterns of the Laramie Peak Bighorn Sheep Herd. Proc. Bienn. Symp. North. Wild sheep and Goat Counc. 8:83-96.

U.S. Department of Interior, Bureau of Land Management. 1985. BLM Manual 6780Habitat Management Plans, Supersedes Rel. 6-60. U.S. Government

Printing office, Washington, D.C.

- 1993. Fish and Wildlife 2000: A Plan For the Future. U.S. Government Printing office, Washington, D.C.

- 1993. Fish and Wildlife 2000: Big Game Management Habitat. BLM/SC/PL-93/002+6700. U.S. Government Printing Office, Washington, D.C.

- 1993. Fish and Wildlife 2000: Resident Fish Habitat Management. BLM/SC/PL-93/003+6700. U.S. Government Printing office, Washington, D.C.

- 1990. Great Divide Resource Area Record of Decision and Approved Resource Management Plan, Draft Resource Management Plan: Rawlins District Office. BLM-WY-PT-573-071/44011. U.S. Government Printing office, Washington, D.C.

1985. Record of Decision for the Resource Management Plan/Final Environmental Impact statement, Draft Environmental Impact statement: Platte River Resource Area, Casper District. BLM-WY-PT-84-008-4410. U.S. Government Printing office, Washington, D.C.

U.S. Department of Interior and Kim Glass. 1986. Wildlife Identification Pocket Guide with Field Dressing Commentary. Outdoor Empire Publishing, Inc., Seattle, Washington.

U.S. Department of Interior, U.S. Fish and Wildlife Service. 1993. Ecological - Services. ES-61411. Cheyenne, Wyoming

Wyoming Game and Fish Department. 1993. Annual Report of Big Game Harvest 1992. Cheyenne, Wyoming.

1989. A Strategic Plan for the Comprehensive Management of Wildife in wyoming (1984-1989), Vol. III. p. 1-14, 31-33.

. 1992. District V Annual Big Game Herd Unit Reports, Vol. XVII, No. 5. Cheyenne, Wyoming. p. 534-545.

- 1993. District V Annual Big Game Herd Unit Reports. Cheyenne, Wyoming. p. 500-522.

1993. District VII Annual Big Game Herd Unit Reports, Vol. XIIX, No. 7. p. 409-442. Cheyenne, Wyoming.

- 1992. Wyoming Bird and Mammal Atlas. Cheyenne, Wyoming. 
。

。

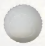

. 


\section{APPENDIX I}

Public Comments, Letters, Discussions

Relevant to the Laramie Peak HMP 
0

0

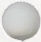


Foundation for North American wild sheep

Ron Ball, President

P.O. Box 5000

Big Piney, Wyoming 83113

Dear Mr. Ball:

The prescribed burn (Environmental Assessment WY-037-EAO-038, BLM) scheduled for the Split Rock area for the Laramie Peak bighorn sheep has been extremely difficult to execute this field season due to the relatively strict windows involved. This burn is located in the south and central portions of T. $24 \mathrm{~N}$. , R. 71 W., section 31 and T. 24 N., R. 72 W., Sections 25 and 36 . A map depicting the estimated burn units, felled-timber cuts and 1974 Duck Creek Wildfire has been attached. The proposed action is to prescribe burn sagebrush/grass in the spring and felled timber in the fall within a 400 acre perimeter area as soon as the windows open.

At this time, to mitigate habitat conditions of enclosed corridors that the sheep attempt to utilize as transportation routes from lambing/nursery grounds to forage areas, a plan has been composed to fell timber manually by the BLM fire crews in July, August or September of this field season. Approximately 400 trees were felled in the summer of 1993 by the BLM fire crews. A three (3) person crew can begin the project one week and another three (3) person crew can continue the following week. The project will involve personnel from the BLM and the Wyoming Game and Fish Department (WGFD) to analyze the best areas to cut for the wildlife. At this point in time the crews are logistically prepared to complete the timber cutting project, however, they are fire personnel and any fire that they are called for wili take precedence throughout the fire season. Since there have been numerous fires to date, and it probably will continue to be a busy fire season, a september cut is probably more realistic.

The BLM and the WGFD are requesting approximately $\$ 1,500.00-\$ 2,000.00$ to pay for per diem and supplies used in the cutting treatments if conditions arise this field season. Is it possible to obtain these funds from those previously set aside for this split Rock prescribed burn? If so, the funds can remain in place until the project has been completed.

Please feel free to contact Mary Read, Wildlife Blologist at this office at 307-324-4841 if this can be achieved. Again, the crews are prepared to complete this project, barring funding and a "break" in the fire conditions throughout the west and south western portions of the U.S.

sincerely,

\section{/S/ CHARLES E REED}

Acting Area Manager

Great Divide Resource Area

1 Attachment: 1 - Map

MJREAD:g8:07/01/94 /common/wild/fundreq.fna
CORRESPONDENCE BTAKP

[ ] subject Function File

[ ] Reading File

[] Case File

[] originator

[ ] Carbon copy

[ ] Distribution Copy

[] Chron. File 
0

0

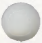




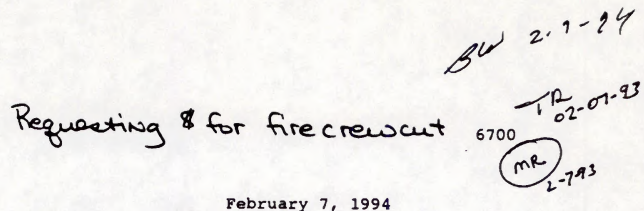

Foundation for North American Wild Sheep (FNAWS)

Freddie Goetz

1555 Spruce Street

Wheatland, Wyoming 82201

Dear Mr. Goetz:

Attached please find copies of both the "Fire Crew Project Work Request Form" and map, as well as the signed (1993) Prescribed Burn Plan for the Split Rock Prescribed Burn. The actions entailed in the Environmental Assessment (EA) for the Split Rock prescribed burn include burning sagebrush/grass areas within the 400 perimeter area in the spring of 1993 and felled timber within the ecosystem in the fall of 1993. The primary objective of this burn is to improve habitat conditions for the Duck Creek subherd of the Laramie Peak bighorn sheep herd in the Laramie Peak Wildlife Habitat area, 25 miles west of Wheatland (R. 72 W., T. 24 N., Sec. 25 and $36 ;$ R. 71 W., T. 24 N., Sec. 31 ).

The "windows" for this burn, or permitable conditions under which the BLM staff members are able to burn, are extremely 'tight' and somewhat restricting due to the particular topography. BLM professionals at both the Great Divide Resource Area (GDRA) and Rawlins District office (RDO) have been monitoring conditions for an open window since the signature of both the EA and burn plan. To mitigate this condition and to alleviate forage quality and quantity conditions on the mountains for the bighorn sheep, the wildlife Biologist, Mary Read, has suggested the following: 1) a timber sale harvesting dead/down beetle-killed trees north of the EA parameter (Pine Mountain) and 2) a 4-section cut utilizing the BLM fire crew, south to south-west of split Rock. An EA for both the timber harvest and fire crew cutting is presently being analyzed and written at this time.

At this time the GDRA is requesting a partial use of the FNAwS funds, originally earmarked for the burn, to be utilized for the fire crew cut. An estimated $\$ 2,500.00-\$ 3,000.00$ will be required for supplies, mileage, and per diem for the crew to complete the task. Attached please refer to the map for the specific cut areas.

Again, the interdisciplinary team is making an 'all-out' concerted effort to complete this burn, but must adhere to the restricted 'windows' within the approved burn plan. If there are any questions please, contact Mary Read, wildife Biologist, at 307-324-4841.

sincerely,

\section{BILLCWNA]SFERBANCE STAMP}

Acting subject runction File

Great fiviceresofice Area

Attachments

[] originator

MJREAD:gs:02/07/94 /common/wild\Firecrew,FNA

[] Carbon Copy

[] Distribution Copy

[] Chron. File 
0

0

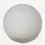




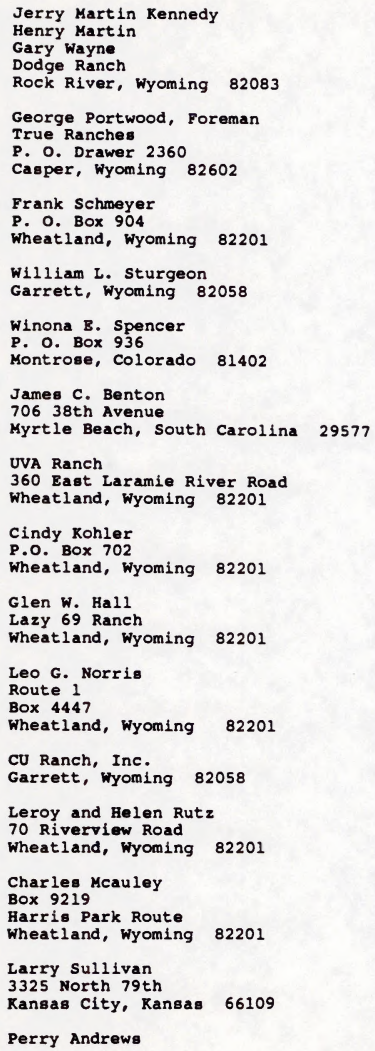




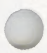

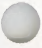

0 


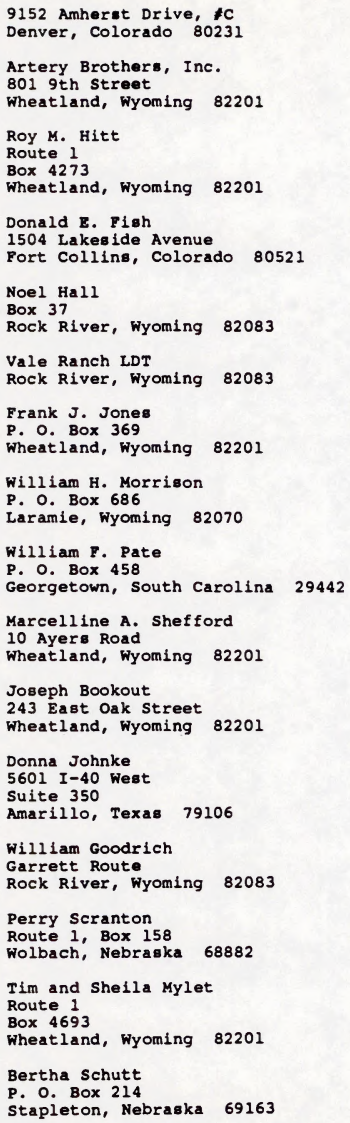




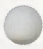

0

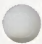




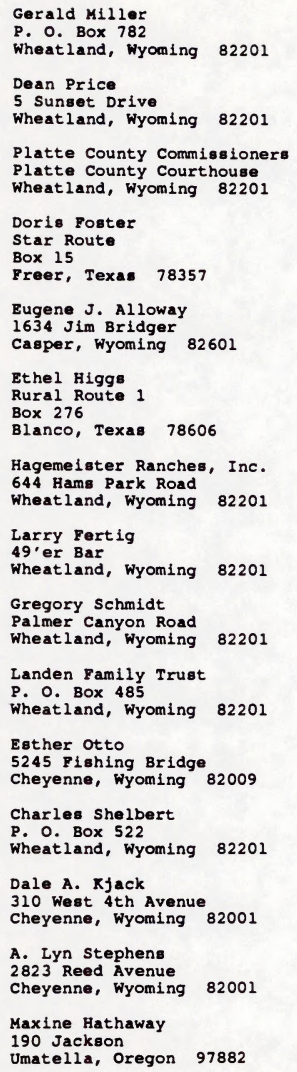


0

0

0 


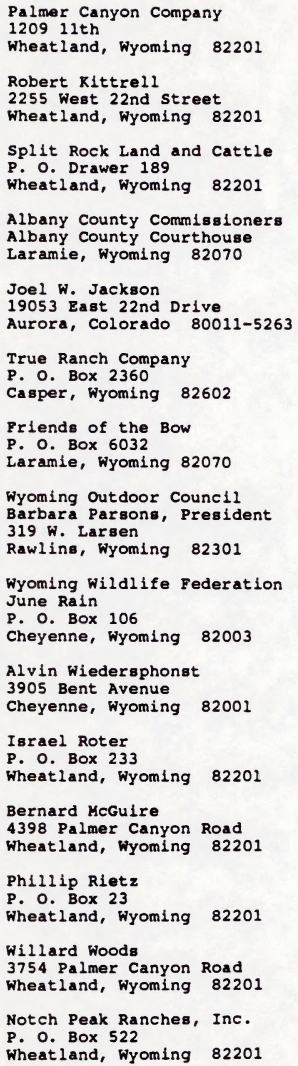


0

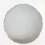

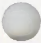




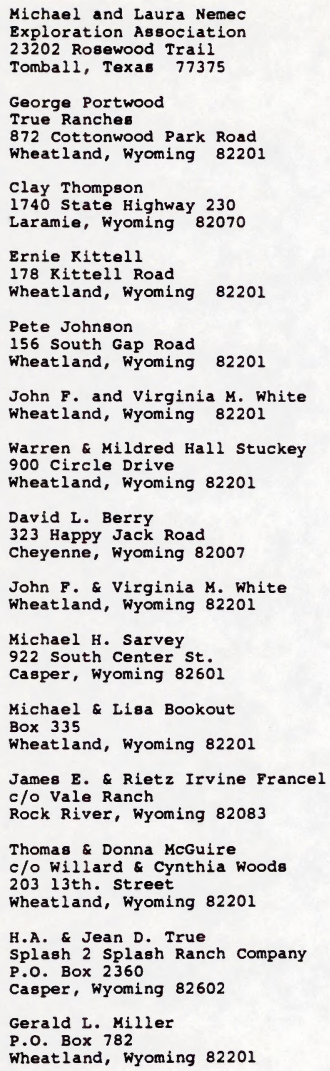




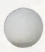

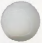

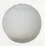




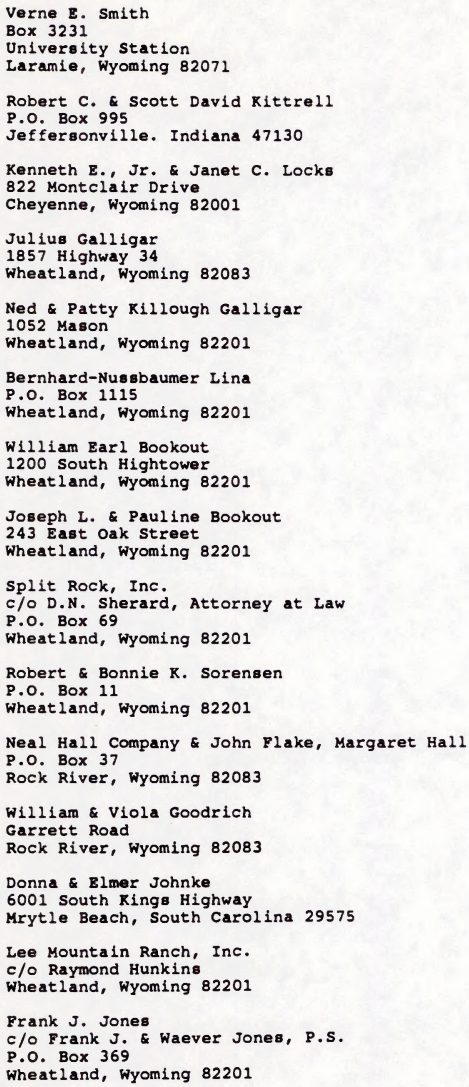


0

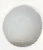

0 
January 12, 1993

Vale Ranch

c/o William Kennedy

Garrett Route

Rock River, Wyoming 82083

Dear Mr. Kennedy:

The Bureau of Land Management and the Wyoming Game and Fish Department are planning a prescribed burn to improve wildlife habitat, with an emphasis on bighorn sheep, in the Laramie Peak Wildlife Habitat Area, located about 25 miles west of Wheatland. The controlled burns are planned for the spring/fall of 1993 when conditions are suitable for burning.

As stated above, the purpose for the burns is to improve habitat quality adjacent to cliffs and other areas used by a diversity of wildlife, as well as bighorn sheep. The spring burn will allow for a controlled burn of sagebrush/grass that permits regrowth of desirable forage plants. The fall burn plan concentrates on the prescribed burning of previously felled beetlekilled ponderosa pines to further improve the quality and quantity of wildife habitat in the Laramie Peak Wildlife Habitat Area.

An environmental analysis, in compliance with the National Environmental Policy Act of 1970, has been conducted in 1991. This letter is to inform you, as an adjacent landowner of the prescribed burn, that the Bureau of Land Management and Wyoming Game and Fish Department, in a joint effort, will be conducting a public information meeting on February 20, 1993, 10:00 A.M. 12:00 P.M. at the Platte County Public Library in wheatland, Wyoming. This meeting is designed to answer any questions and/or address any comments pertaining to this particular prescribed burn.

Mary Read, Wildife Biologist, Larry Trapp, Fire Management officer, and Dick visit Larson, Soil Scientist/Prescribed Burn Boss would like to meet with you $\{$ concerning this particular prescribed burn at your convenience. If you have any questions, please contact Mary Read at Great Divide Resource Area office (307) 324-4841.

sincerely,

's/ Jim H. Webb

\section{ACTING}

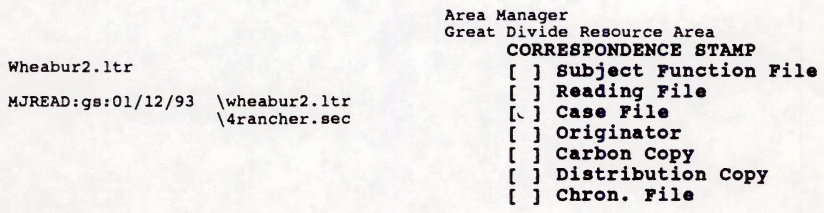


0

0

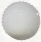




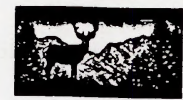

\section{WOMING \\ GAMEANDFISH \\ DEPARTMENT}

Contact: Rich Guenzel (307) 745-4046

January 22, 1993

Mary Read, BLM Wildlife Biologist, (307) 324-4841

\section{PRESCRIBED BURNS PLANNED TO IMPROVE BIGHORN SHEEP HABITAT}

The Bureau of Land Management and the Wyoming Game and Fish Department are planning prescribed burns, in the spring and fall of 1993, to improve bighom sheep habitat on the Laramie Peak Wildlife Habitat Area, about 25 miles west of Wheatland.

The burns were recammended by a study of the Laramie Peak bighorn sheep herd as a way to improve habitat. The burns will cover about 400 acres of steep public lands adjacent to cliffs used by the animals. The burning of old growth sagebrush this spring will promote the regrowth and nutritional quality of grasses that provide valuable forage, especially for ewes and lambs. The fall burn is designed to open up passage routes for the sheep.

"Last year we went in and cut down beetle-killed ponderosa pines in the area," said Bob Gurney, G\&F habitat supervisor for southeast Wyoming. "Dropping these trees, in combination with burning this area in the fall, will open up travel lanes for the sheep between the cliffs and forage areas. We're very hopeful this project will significantly improve the bighorn sheep habitat on the Laramie Peak unit." 
PRESCRIBDD BURNS PLANNED TO IMIPRONE BIGHORN SHEFP HABITAT page 2

An informational public meeting about the burns will be held by the G\&F and BLM in Wheatland, Feb. 20, 10:00 a.m. to 12:00 p.m. at the Wheatland Public Library. The public is invited to attend to learn about the project and offer their views.

"This project is an outstanding example of how the BIM, affected landowners and grazing permittees, numerous public agencies, conservation organizations and private citizens can copperate together for the benefit of wildlife," said Al Pierson, Rawlins district manager for BLM. "By pooling our talents and resources we are able to get much more accomplished toward reaching a common goal."

Prescribed burning is a frequently used habitat management tool used to control certain types of vegetation and to promote the growth of grasses to improve forage for wildlife and livestock. In North America, the technique was first used by several Native American tribes. Prescribed burns are not conducted until weather and moisture conditions are suitable, and adequate manpower and equipment are in place to confine the fire to a predetermined area.

The Laramie Peak prescribed burns are supported by the Foundation for North American Wild Sheep; Southeast Wyoming Resource and Conservation Development District; Myron J. Wakkuri, who donated the proceeds from a guided hunt to the project; BLM; G\&F; U.S. Forest Service and Laramie Rivers Conservation District.

For more information about the project contact Rich Guenzel, (more) 
PRESCRIBED BURNS PLANNED TO IMPROVE BIGHORN SHEEP HABITAT page 3

G\&F game biologist at 1-800-843-2353 or Mary Read, BLM wildlife biologist at $324-4841$.

G-F 
0

0

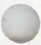


July 19, 1991

syron J. Mekkur1

Project Coordinator

USDA SC:

1002-b Yth Street

weetland, whoulng 82201

Dear Ar. Wakkur 1;

unclosec please fine the information you requested conceralng cost, tine frase and location for the pre-bura timber cutting project at split rock. The cuttlag vould take plece on BLH land, T. 24 N., R. $71 \mathrm{~W}$, , Sec. 31, and rould $\rightarrow$ total approxiantely 27 acres. The roundiat northern-wot cut 1s approximately 14 acres and the long outhern-oos cut is approximately 13 acres.

The southern cut unit has a higher tree density than the oorthern unlt. Using stand density data we estimate an average of 50 trees/acre for the two stands.

The eatimated cost of the project:

1 true reller:

$\$ 11.00 /$ hour

1 wan can cuts

4 trees/hour

$\$ /$ treu:

$\$ 2.75 /$ tree

with added expense, estimate: \$5.00/tree

twerefore $\$ 5.00 /$ tree $\times$ SU trees/acre $\times 27$ acres $=\$ 6750.00$

Ilee frane for project

Su crees/acre $\times 27$ acres - 337.5 hours for 1 wan

4 trees/hour

ice project wll go to contract if blM nandles it and w111 therefore be b1d on. Considering the rough terraln and difficult access, we nay not get a bid as Low as so7su.uu.

If Bh handles the coutract, ve require a 157 adalalstrative overiead fee, vilica would bring the eatimate of $\$ 6750.00$ to $\$ 7762$.3U. The Wyoalng Gane and risil beparteent nay be villag to iandle tae contract thereby elininating tine overhead fee. 
We appreciate your interest in this project. If you have any question, please contact Deborah Poller at (307) $324-4841$.

sincerely,

S.

Area Manager

Z Great Divide Resource Area

Lroeiker:8jr:7/10/Y1:U421K 


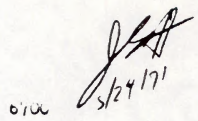

say 24,1 yyl

\section{hyron daxirur?}

r roject voorainator

Uuna Suís

lsu< - D yta stregt

weatland, Il $0<<u l$

Lear Ar. makxur1:

wcloged fiease find a copy of the bain urent proposal for tne split kock prescribod burn in the waramie feak/buck Creex area.

Lesoran roolker has done bose checking and Lasen't gotten very favoraole feedpack on the timber cutting proposal. It vill be imposalole to use eumer temporaries vaica means a contract vould be required. Uur forester estiwated a cost of several nundred dollars per acre for a contrector to get the joo 1one.

Lejpite tae opposition, wedoran still belleves 1 t would oe worth ville to cut out some or the areas oi prine conceru, particularly those fan acres near tae

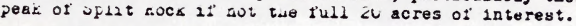

ie greatly appreciate your participation in the laramio Peax Elgnorn Sneop comittee aeeting on sorday tue 2Lto of Aay, and tre interest you've taken in tn18 project. It you nave any questions please contact veboran roelxer at ( $x i 1) j<4-4041$.

sincerely. 


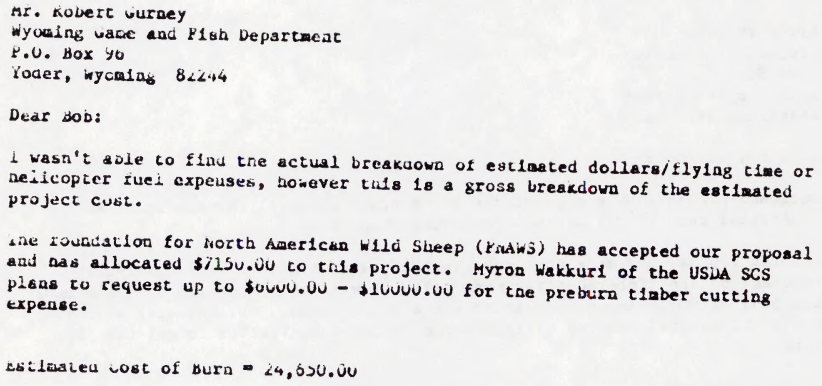

1 nope these 1 igures w111 be of delp to you.

$$
\text { sincerely, }
$$

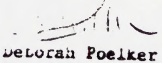




\section{Foundation for North American Wild Sheep}

720 ALLEN AVENUE • CODY. WYOMING 82414-3402 • PHONE (307) 527-6261 FAX 1307$)$ \$27.7117

OFTCERS AND

DIRECTORS

Howard W. Pollock

Ineneneasel Prosiden

Conved Towes Sunc 134-N 1600 South Eads Sureat Arliagen VA 22202.2914 (203) 281.1137 (0)

(703) 521.0019 (Telefax)

Dr. Robert DiGraxis

Find Vice-Presiden

1894 Tablerock Roed

Bone. $10 \mathbf{8 7 1 2}$

(200) $376-7413(\mathrm{O})$

(208) $336-5044(\mathrm{H})$

Daniel A. Pedrotti

Seread Vier-Fresidew

200 N. Shoreline Boulevard

Saive 2400

Corpus Cansti, TX 78401

(512) 8s4-2443 (O)

(512) 991 .612 (H)

Phyllis Carison

Secrutor

7185132 ind Se. West

Apple Vhiey. MN 55124

(612) 431 4488 (H)

Des Artery

Tmexare

Dive

and WY 82201 522.2029 (H)

(von) 322-3332 (Message)

Pete Clestlaro

Alecteser Treasum

2928 E- Whatingion

moenix. AZ ESOHA

(602) 340.879 (H)

(600) 275-7096 (Phoneffax)

Garry Viace

P. Don 648

For SL boton British Columbis

Conede VIS 4 He

(604) 725-4681 (O)

Johney Dith

P.O. Dou 4574

Wrisens Leke, B.C.

Cande $\mathrm{VC}_{2 \mathrm{~V}} \mathrm{~V}$

(604) 394-7646

Hervey Kadlex

Past Pridira

16970 Crocus Street N.W.

Andover MON 55304

(612) 753-3061 (H)

Doe Schmaly

P.O. Bos 604

Costy. WY 22414

(307) 587.5929

Tom Brom

17130 wew 57 in Place

Colden $\mathrm{CO}$ soutos

(m) $272-2502(\mathrm{HI}$

291.7212 (O)

siosid (Telefux)

Karea Werbelow

Susiaess Alininustrato
May 13, 1991

Deborah Poelker

BLM

P.0. Box 670

Rawlins, WY 82301

Dear Deborah,

On behalf of the Foundation for North American Wild Sheep and the Wyoming Chapter of FNAWS, I would like to congratulate you on the acceptance of your project 91-54 titled "Split Rock Prescribed Burn". The Wyoming Chapter of FNAWS has taker a special interest in this project and has agreed to fund it through their chapter. Kathy M. Gay, Wyoming FNAWS Secretary and Treasurer, will be your contact for disbursement of funds. She can be reached at 307856-4968 or 11809 thw 26-789, Shoshoni, WY 82649.

of the $\$ 7150.00$ requested, $\$ 7150.00$ has been allocated to this project. Per our conversation, Deborah, this money has been allocated contingent on: That the money be deposited in the Range Improvement fund and that there are no administrative fees associated with this project. FNAWS and it's chapters are ddamant that we are not charged with administrative fees now or in the future. According to this project's Grant application, the $\$ 7150.00$ was expensed to helicopter. He would expect that if this project did not use all of these funds, that only the amount needed would be requested, or returned to WY FNAWS as the case may be.

We are extremely proud and excited to be working in a partnership with the Bureau of Land Management. He are a non-profit organization with a completely volunteer board. Our Board of Directors have a "hands on" philosophy to these projects and physically get involved whenever possible. They are responsible for master-minding our conventions which this year alone funded over $\$ 600,000.00$ in projects and returned permit money, totaling over 5 million dollars to date in conservation projects. Surely you can understand why administrative costs are not an option.

If I can be of further assistance, please do not hesitate to contact me. Kathy Gay will be receiving correspondence and will be in touch with you.

Sincerely,
Nlati Meilsen

Marti A. Nielsen

Grant-in-Aid Coordinator

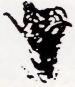

Marti Nielsen GIA Coordinator
Foundation for North American Wild Sbeep

FNAws Headquanco 
Mey 29, 1991

Heworadu

To: State Director, Hooing (950)

Acta: Krí Rust

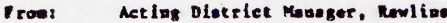

Subject: lequent for Weiver of Mdabietretive sureburge

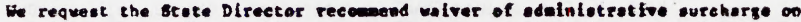

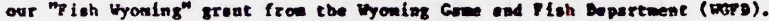
The grent is for a floberice project titled Teton keservoft boet lasp and Jetty." The WOP is ohariag \$13,090 towerd the coet of this profect and bas

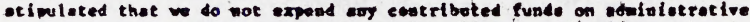
coets. He queat loo wether an 18 percent udalaiotrative aurcharge Is. appropriate for Colleaze Cost shere profects. The War foels that

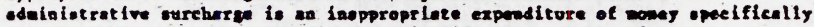
deslzated for -the-zroud fish and wilife mangenent projecto.

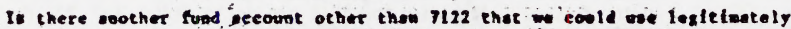
co avoid adainietrative sureharget cosld - blanket valver for Cuallenge Cout stive costributed funde be requented We hive wother eost oliere profect

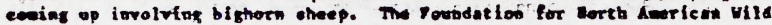
Sheep hat tentatively appreved this profect. It io deo the polley of the Foundation thet contributed wonice vill not be ead te fund adainfetretive ceste. We are forwarding - letzer to that effect (ettachineve 1) and vill seed asother request for wiver of eduini int rative ourebiarge.

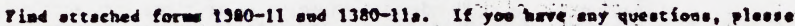

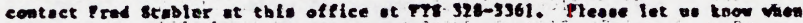

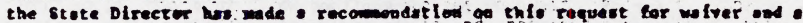

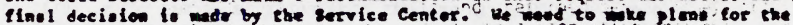
oun field sescos:"

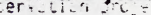

cc: Mark Gorges, wiso (932) Jack Welch, LaA 
${ }_{10}^{11 \mathrm{a}}$ a.

\section{EXCEPTION INDIRECT COST RATE - TRUST FUND PROJECT REQUEST FORM}

To:

Service Center Director (SC-615)

From:

Subject: Exception Indirect Cost Rate - Tryst Fund Project

Please establish the following Trust Pund project, which has been authorized Financial System.

SUBACTIVITY:

(PROGRAM)

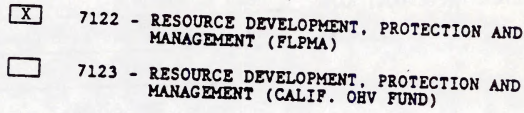

PROJECT NUMBER:

EXCEPTION INDIRECT COST RATE: 0 - 0

ORGANIZATION CODE

OF LEAD OFFICE:

$$
\underline{\mathrm{Y}} \cdot \underline{0} \underline{3} \underline{0}
$$

This form is to be attached to the Trust Fund Project Number Assignment And

Approving official has completed for input into the Pederal Binancial System.
.

NAME OR APPROVING OPFICIAL (P1EAse TYPE),

SIGNATURE OF APPROVING OFPICIAL:

TITLE:

DATE: 


\section{TRUST FUND PROJECT NUME ASSINNMENT AND INFORMATION DATA FORM}

SUBACIIVITY:

7110 - CONVEYANCE OF OMITTED LANDS

121 - RESOURCE DEVELOPMENT, PROTECTION, AND MANAGERNT (TAYLOR
GRAZING ACT)

[X 7122 - RESOURCE DEVELOPMENT, PROTECTION AND MANAGDMENT (ELPMA)

1123 - RESOURCE DEVELOEMENT. PROTECTION AND MANAGDMENT (CALIP.
OHV FUND)

7130 - PUBLIC SURVEY

7300 - TRUSTEE RUNDS (ALASRA TOWNSITES ONLY)

PROJECT NUMBER:

PROJECT NAME:

- - - CASE FILE MUMBR, Teton Reservoir Boat Ramp and Jetty

APPLICANT (VENDOR) NAME: John Baughman

\begin{tabular}{ll} 
ADDRESS: & $\frac{\text { Wyoming Game and Fish Department }}{5400 \text { Bishop Blvd. }}$ \\
TELEPHONE NUMBER: & Cheyenne, WY 82006 \\
\hline
\end{tabular}

ORGANIZATION CODE

OF LEAS OFFICE:

ORGANIZATION CODE OF

OTHER OFFICES CHARGING

TO THE PROJECT:

$\underline{\mathrm{Y}} \underline{\mathrm{O}} \underline{\mathbf{3}} \underline{0}$

EXCEPTION INDIRECT COSI

RATE (7122 AND 7123):

$-0$

PROJEC? MANAGER NAME

AND TELEPHONE NUMEER:

Fred Stabler, FTS 328-3361

VENDOR NUMBER;

AGREDMENT NUMBER:

RA DOCUMENT NUMBER:

INPOT BY:

DATE: $-\ldots-1-1-$ 
Prop=. a was

+ib 92

\title{
FFIOJECT TITLE:
}

LOCATION:

$\because 5=0$

. 05

$\Rightarrow+t \geq z$ manen? I.

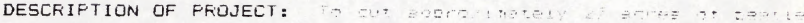

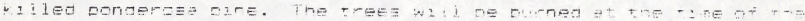

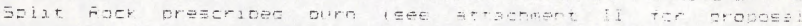

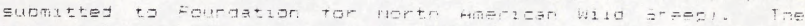
whoming EAme and f

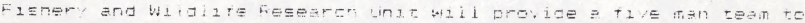

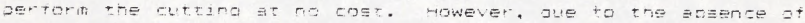
rojag anto the argz and the extremely rugaga terrain the zrew wil

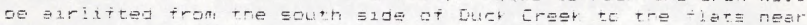
Solit Fiock.
\end{abstract}

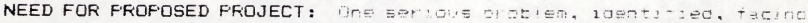

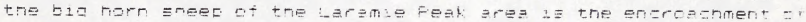

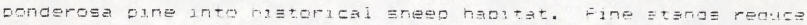

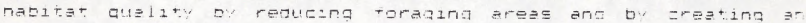

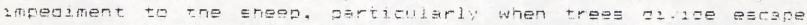

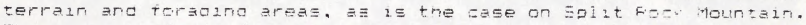

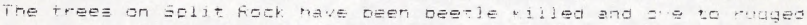
terrain are not salvable oy marvesting.

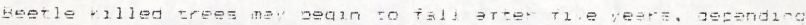

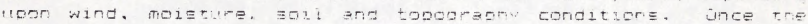

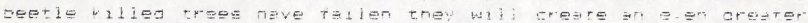
rinderance to the sneep. on the ground than standire trees. Tre

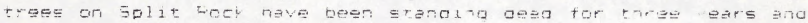
ionger and some nave airead talien.

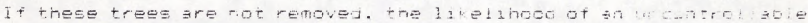

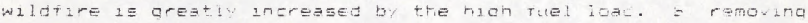

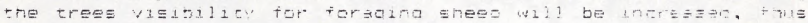
reducing the time and energy gpent ar a glaze ot ajp-r. i: nes

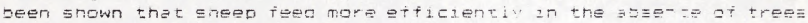

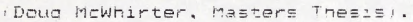

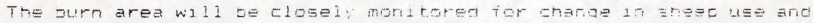

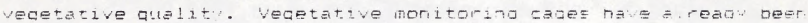

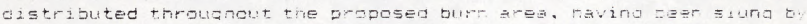
melicopter in Geptengo- 1941 into this remote and rugopa ares.

The eminent guestion remains, how to tamove thie treis:

1) to dezn the greatest benetit trom the ourn

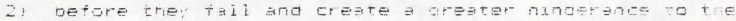
shesen

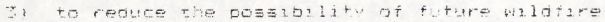

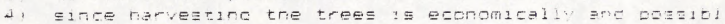
orve $1: 321$. Lin

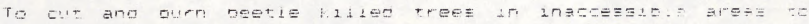

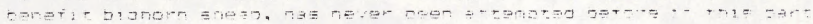




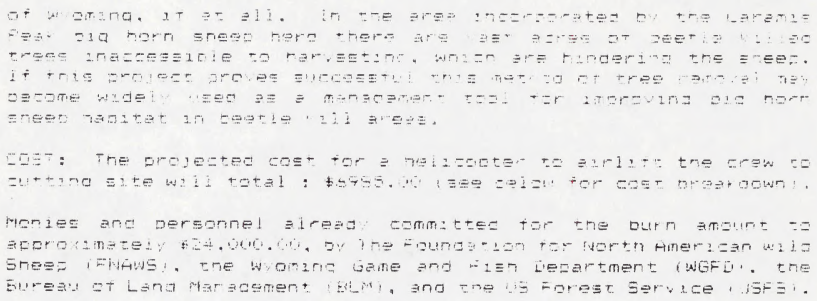




\section{BURN :}

\section{PERSONNEL \& PER DIEM:}

To blackline and burn: 15 people $\mathrm{x} \$ 12.00 \mathrm{hr} \times 10 \mathrm{hrs} /$ day $\mathrm{x} 5$ days $=\$ 9000.00$

per diem: 15 people $x \$ 30.00 \times 5$ days=

$\$ 2250.00$

Holding force/postburn: 2 people $\times \$ 12.00 / \mathrm{hr} \times 10 \mathrm{hrs} /$ day $\times 2$ days $=\$ 480.00$

per diem: 2 people $\times 30.00 /$ day $\times 2$ days $=$

$\$ 120.00$

Travel expense:

$\$ 450.00$

SUB-TUTAL $\$ 12,300.00$

\section{HRLICOPTER:}

WGFD:

Helicopter

Helitorch fuel

Fuel truck

Per diem pilot \& truck driver

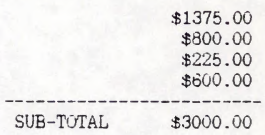

FNAWS:

Helicopter

SUB-TOTAL

$\$ 7150.00$

TOTAL FOR BURN $=\$ 22,450$

\section{TIMBRR CUT:}

Helicopter: (breakdown in proposal) SUB-TOTAL $\$ 6985.00$

Personnel (WGFD): 5 people $\times \$ 12.00 \times 10 \mathrm{hrs} /$ day $\times 5$ days: $\$ 3000.00$ Fer diem: 5 people $x 30.00 /$ day $x 5$ days: 


\section{COST BRRAKDOWN PKR AGRNCY:}

BURN:

WGFD:

Helicopter, fuel...

personnel \& per diem (5 people for 5 days):

$\$ 3000.00$

Travel expense:

USFS:

personnel \& per diem ( 1 person for 5 days):

BLM:

Fersonnel \& per diem- burn $19 \mathrm{p}=\mathrm{pl}$ lo fir 5 , faro:

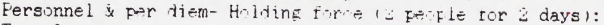

Travel expense:

ENAWS:

Helicopter:

$\$ 7150.00$

TOTAL COST POR BURN $=\$ 22,450.00$

\section{TIMBBR CUT:}

WGFD:

Personnel \& per diem:

$\$ .3750 .00$

SCS Froposal:

Helicopter:

$\$ 6985.00$

TOTAL COST FOR TIMBKR CUT $=10,735.00$

TOTAL COST FOR TIMBER CUT \& BURN PBR AGENCY:

WGFD:

USFS:

$\$ 10.650 .00$

$\$ 750.00$

BLM:

$\$ 7650.100$

FNAWS:

$\$ 7150.00$

SCS Froposal:

$\$ 6985.00$ 


\section{Fire Management and Wildlife}

\section{Habitat Extension Bulletin}

No. 49

Prescribed burning can be an effective management tool for improvement of wildlife habitat. Farm and ranch owners in the state of Wyoming can improve habitat for wildlife, and increase forage for domestic livestock by including prescribed burning in land management planning.

A prescribed fire is quite different from a "wildfire." Wildfires are unplanned and can be destructive, while prescribed burns are carefully planned to maximize benefits and minimize the chance of uncontrolled burning.
This bulletin describes the steps to complete a prescribed burn, expected results, and the effects on certain wildlife species.

Prescribed fire is traditionally associated with management of public forest lands. However, a great deal of fire management can be implemented on private lands where sagebrush communities predominate. Much of the 94 million acres of sagebrush habitat in the West can be improved for wildlife and livestock. Since sagebrush communities are so widespread in

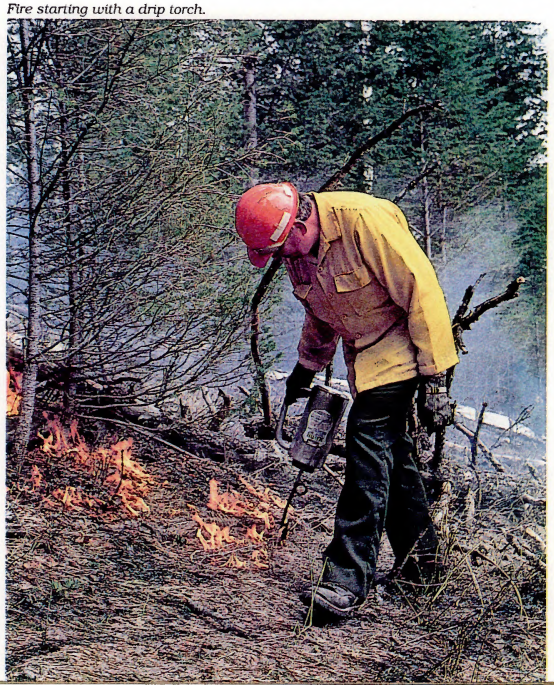

\section{Habitat Extension Services}



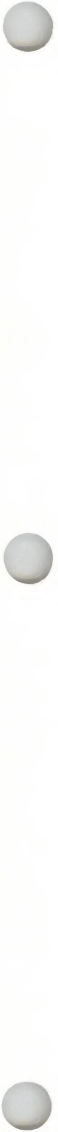


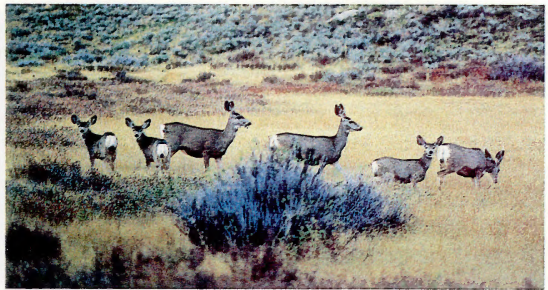

Mule deer (left) and other big game thrive on grass. shrubs, and aspen rejuvenated by fire. A controlled burn (next page) improves forage in the year following the fire (below).

grasses, shrubs, and in some cases, trees, may invade the area, reducing preferred forage quality and availability. Prescribed burning provides a way to reduce these invading

Wyoming and burning of these areas is relatively common, they are discussed throughout this bulletin.

All sagebrush is not created equal: there are several subspecies, many of which occur in Wyoming. Common examples include Wyoming big sage, bud sage, black sage, and silver sage. These subspecies occur at elevations ranging from 2,000 to 10,000 feet and differ enough that unique fire prescription plans are needed for each type.

\section{Planning Prescribed Burns}

Before burning is conducted, or perhaps even considered as an option, the landowner should evaluate the condition of his or her property. Prescribed burning is one of many tools useful for range improvement; it is not a cure-all. While some range problems can be solved using prescribed burns, many others can not. There are three sound management reasons to burn areas:

Over-utilization is a nice word for overgrazing. Overgrazing normally leads to a loss of grasses and forbs, after which plant species such as big sagebrush become the dominant plants in the area. In certain cases, lands that have been abused in this manner can be rejuvenated through burning.

Under-utilization is not common but can be a problem, particularly in grasslands. Periodic burning of prairie communities was a natural cyclic occurrence in years past. Fire suppression in these areas combined with little or no grazing can lead to under-utilization. Bunch grasses (those species which colonize areas through root stocks rather than rhizomes) can become decadent, with old growth choking out new, eventually impeding plant growth. Prescribed burning can remove dead growth. return nutrients to the soil, and stimulate plant root systems to produce new growth only days after a fire passes.

Finally, succession is a sound reason for prescribed burning. In areas where fire has been suppressed, many undesirable species of plants and encourage establishment of more desirable forage plants.

After reviewing the range condition and determining that a prescribed burn can achieve the desired improvements, the landowner should formulate a fire use plan. This plan consists of the following components:

\section{Bum Area}

First, the burn area borders must be clearly defined. This will help later when fire breaks are established. Rather than burning large acreages, plan on burning smaller sections within the larger area on a yearly rotational system. This rotational burning will maintain habitat diversity and benefit a variety of wildlife species. 2. Burn Objectives

Secondly, burn objectives must be clearly identified. What is the purpose of the burn? What effect(s) is/are desired? When should the burn be conducted (season, time of day, number of days)? Variables of a prescribed burn can be manipulated so a landowner can achieve the exact desired results.

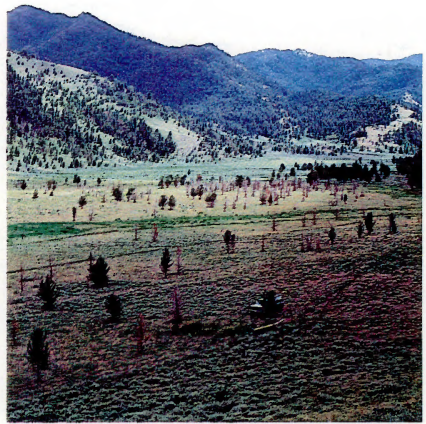



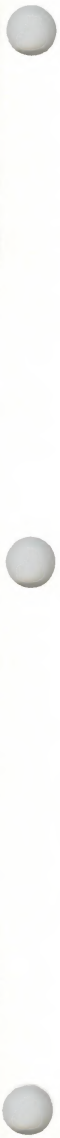


\section{Burn Prescription}

Thirdly, a fire prescription must be developed to reach the established objectives. The prescription is comprised of a number of components which result in a fire that accomplishes these established objectives. For example, a fire that burns too hot may destroy preferred vegetation or sub-surface tissue of preferred plants, or it may jump fire breaks and become uncontrolled. A fire that burns too cool may not spread adequately throughout the burn area, resulting in incomplete combustion of fire fuels. spot burning, and failure of the burn objectives.

One of the major prescription components is the time of year for burning to obtain desired results. From a wildlife standpoint, this decision can be critical. Ground nesting birds, including sage grouse, can be severely impacted if burns are conducted between April and August. To prevent wildlife impacts and still provide other benefits, early spring or fall are the best times to conduct a prescribed burn.

Deciding when to burn is partially dependent upon burn objectives and the plants indigenous to the site. Burns should be conducted when preferred plants are dormant. Warm season grasses such as buffalo grass and blue grama benefit from a spring burn, while they are still dormant. Cool season grasses such as bluebunch wheatgrass, Idaho fescue, western wheatgrass, and prairie junegrass benefit from a fall burn following their growing season. In general, forbs are negatively impacted by spring burns and benefitted by fall burns, particularly those forbs which grow from root stocks.

Examining each burn season reveals other considerations.

\section{Spring burns}

Fuel moisture is relatively high during this period, resulting in a cooler burn that still kills sagebrush. Cooler fires are easier to control and much less likely to leap fire lines. Snow banks can be used for firebreaks to reduce firebreak construction efforts and associated burning costs. Spring burns allow regrowth during the summer growing season. This may be important, for example, on a big game winter range where vegetative regrowth will provide critical forage for big game during the coming winter. However, in spring, fuel moisture content may be too high to successfully carry a fire, producing incomplete and spot burning.

\section{Fall burns}

In the fall, fuel moisture content is typically low enough to achieve burn objectives, and weather conditions are usually favorable for

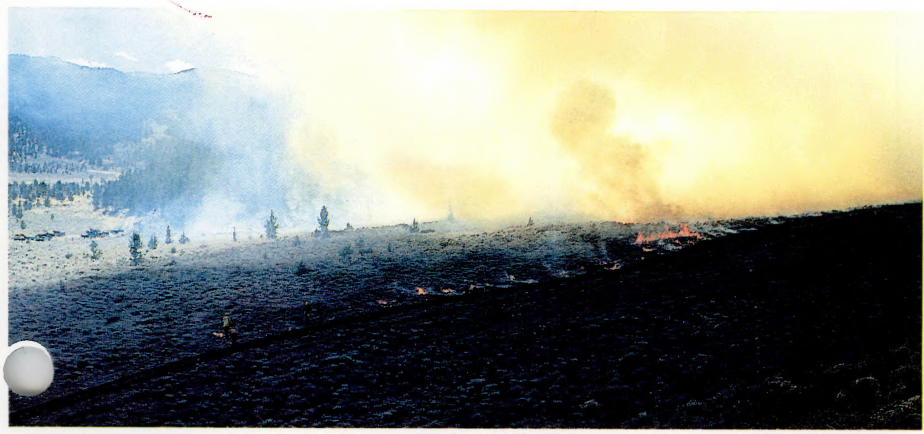



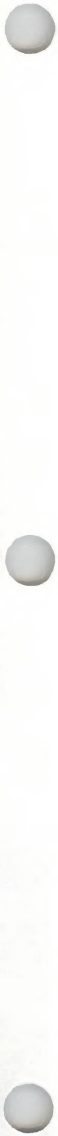
Fire in old stands of willow (center and next page) or sagebrush (bottom) stimulates new growth and improves forage value. A wildflower sprouts in the aftermath of a ground fire in Yellowstone (left).
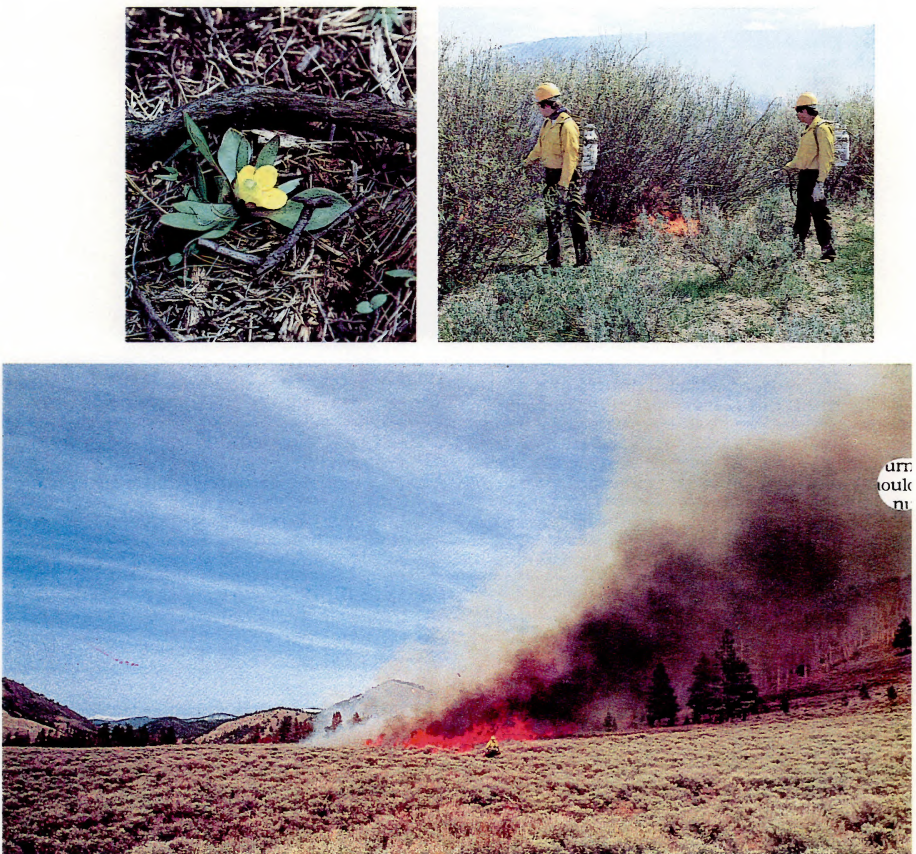

prescribed burning.

Typically, fall burns are more effective in eliminating big sagebrush. Since big sagebrush drops its seeds in late fall, early fall burning removes both mature plants and their seeds. This helps to prevent quick re-establishment of sagebrush the following spring and allows desirable forage plants to colonize the burn area. Grasses and bitterbrush, often associated with big sage communities, drop their seeds in early summer, thereby avoiding detrimental effects from fall burning. Burned areas provide a superb environment for these seeds to germinate and establish themselves.

On the negative side, fall burns may require more firebreaks, and the hotter, drier conditions of a fall burn increase the risk of fire leaping a firebreak or spotting to other areas. Despite these potential drawbacks, fall burns are recommended for big sagebrush stands. 

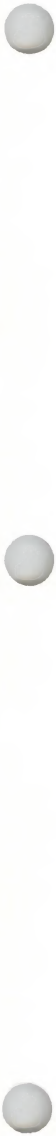


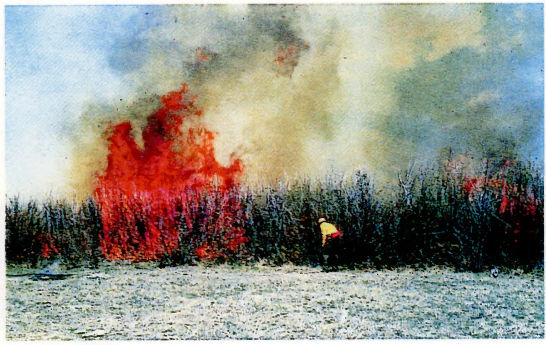

germination sooner than other areas. Vegetation from burned areas has a higher palatability and nutritional content that is very attractive to livestock and big game alike. Increased nutrient flow and increased soil moisture also result from a prescribed burn.

Burned areas should be rested from domestic livestock grazing for at least two years. This allows desirable plants to become fully established, while minimizing colonization of weedy species. If this rest period is not observed, the likelihood of sagebrush re-invasion is high, with reduced benefits of burning. Prescribed fire affects wildlife in different ways. Some of

\section{Burning Plan}

The last component of a fire use plan is the burning plan. This is the actual "blueprint" of the planned fire and includes the following components:

\section{Fuel Treatments}

In certain cases, sparse fuels may have to be more evenly distributed or augmented in the burn area to obtain the desired results. However, fuel may be limited in some areas and excessive in others. Fuel may need to be more evenly distributed to avoid very hot burns or blowups that might result in fire escaping. Fire Lines

Fire lines, whether natural or constructed, should completely encompass the treatment area. In most cases, fire lines 10 feet wide will contain a fire, but there are exceptions to this rule. For instance, the downwind fire break may need to be 50 feet or more wide to prevent a prescribed burn from escaping.

\section{Prescribed Burning Effects}

What effects can a land manager expect from a successful burn, and how does this benefit wildlife? One of the most visible effects of a prescribed fire is a decrease in canopy cover of timber and large shrubs such as sagebrush. This allows more sunlight to reach the ground, stimulating growth of desirable grasses and forbs.

Soil temperatures tend to be higher on burned areas and become snow-free sooner in spring as the exposed, blackened soil is warmed by the sun. The added nutrient availability produced by burned vegetative material encourages seed these effects are listed below:

\section{Small mammals}

Most small mammals are initially adversely affected by fire. Populations of small mammal species as well as the number of species (diversity) of small mammals in a burn area will be initially reduced. Burrowing animals often escape the flames and heat from all but the hottest fires by remaining underground during fire passage. Most small mammals are killed indirectly from cover and food reduction in the burned area. For example, small mammals foraging in a burned area become easy targets for predators such as hawks and owls. As vegetation regenerates however, small mammals from nearby locations will re-colonize the burned area.

\section{Bird Species}

Areas known to support nesting birds should not be burned until fall to avoid loss of nesting cover. This allows nesting birds to use the available cover and successfully raise broods. In the spring following a burn, adequate residual nesting cover may be lacking. To accommodate ground nesting birds in this situation, burns should be relatively small to maintain a portion of the area in nesting cover at all times.

\section{Pronghorn Antelope}

Few studies have been conducted regarding fire effects on pronghorn antelope and their range. Although antelope feed on a combination of grasses, forbs, and browse, they prefer forbs particularly in spring and summer. They rely 

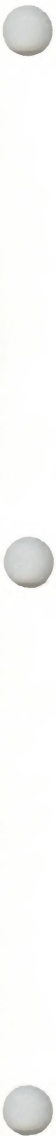
heavily on sagebrush during the winter months, so anything done to promote forb production while at the same time preserving 30 to 50 percent of the original shrub cover present will be beneficial to antelope.

\section{Mule Deer}

Mule deer, like most big game species, will readily utilize burned areas, especially after green-up. Deer are attracted to newly developing, succulent shoots and young sprouts on the burn area. Studies indicate that the higher nutritional value of these plants will be maintained for 1 to 3 years post-burn. After that period, forage nutrient levels will decline until they reach a level that existed prior to the burn. At that point, the area may need to be burned again.

Studies also show that increased forage quality of burned areas leads to healthier, larger animals, and in the case of does, higher ovulation rates and higher birth rates. A critical consideration for deer is to avoid burning all cover in an area. This can be accomplished by burning smaller areas (up to 60 acres) to leave nearby cover for deer or preserve localized patches of cover within a burned area. In either case, 40 percent or more of the original shrub cover should remain to optimize deer numbers.

\section{E1k}

Elk feed on a combination of grasses, forbs, and browse. Prescriptions that promote regeneration of these plants will likely benefit elk. Prescribed burning studies of elk habitat indicate that fall burns have the best long-term effects for elk herds. If a fall burn is correctly done, maximum use by elk will occur after 7 years.

One favorite food item of elk normally promoted by fire is aspen. Aspen trees regenerate by producing shoots from the parent tree. This process, called "suckering," is often stimulated by fire, resulting in an upsurge of aspen shoots and increased forage for elk.

One other beneficial effect of fire in elk habitat is a resultant decrease in browse height. Not only is regenerated browse easier for elk to reach, but the succulence and nutritional value of browse are increased, resulting in healthier animals.

\section{Conclusions}

The process of prescribed burning is far more involved than simply setting fire to an area. It involves considering a number of interrelated variables to meet specific management objectives. The process, because of its complexity and associated danger, demands that only experts conduct such activities.

For more information about prescribed burning and possible treatment of your lands, consult one or more of the following persons: your local Agricultural Extension agent, the Soil Conservation Service, the Wyoming Game and Fish Department's fire management supervisor or habitat personnel, and the U.S. Forest Service fire management supervisor in your area.

For further reading on the subject of prescribed burning, please consult the following references:

Chandler, Craig, Phillip Cheney, Philip Thomas, Louis Trabaud, and Dave Williams. 1983. Fire in forestry. John Wiley and Sons, New York, NY. $450 \mathrm{pp}$.

Pyne, Stephen J., 1982. Fire in America, a cultural history of wildland and rural fire. Princeton University Press, Princeton, NJ. 654 pp.

Pyne, Stephen J., 1984, Introduction to wildland fire, fire management in the United States. John Wiley and Sons, New York, NY. 455 pp.

*Smith, Michael A., Jerrold L. Dodd, and J. Daniel Rodgers. 1985. Prescribed burning on Wyoming rangeland. Agricultural Extension Service bulletin B-810.

Wright, Henry A., and Arthur W. Bailey. 1982. Fire ecology. United States and Canada. John Wiley and Sons, New York, NY. 501 pp.

*Dr. Smith is a fire extension specialist in the Department of Range Management at the University of Wyoming. Laramie. He will conduct prescribed burns on private lands for landowners.

Written by Evin Oneale, through the Wyoming Cooperative Fishery and Wildlife Research Unit.

This publication is one in a series of habitat extension bulletins produced by the Wyoming Game and Fish Department. Call 1-800-842-1934 for additional information or assistance. 

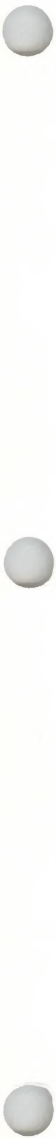
Tit

$x_{3} x^{2}+3 x$

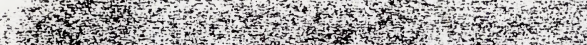

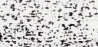
Sheep

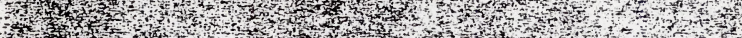

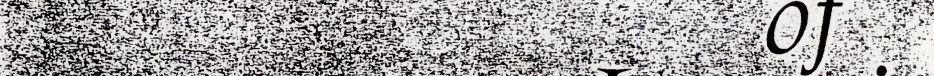

37 th

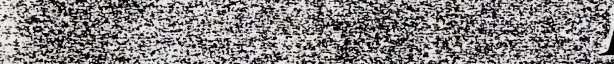

iaranie

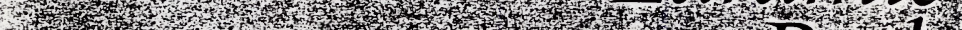

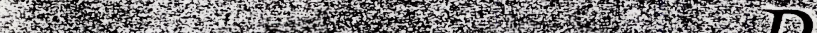

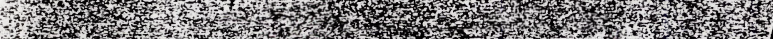

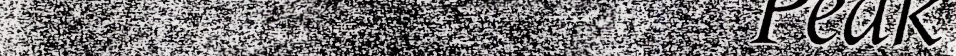

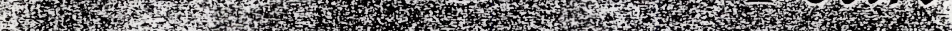

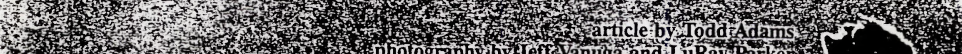

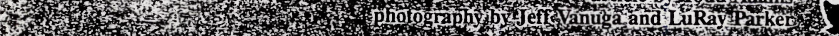

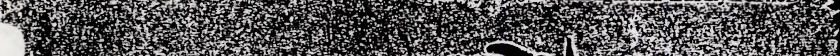

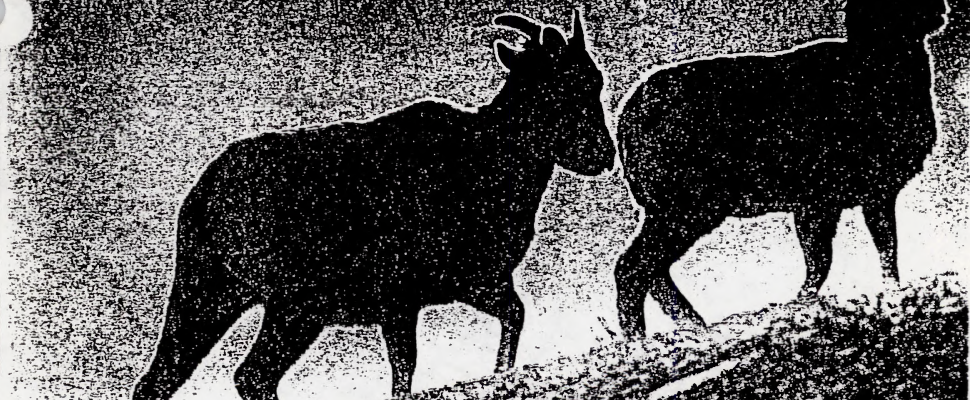

brot

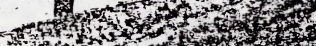

W.

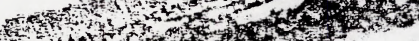

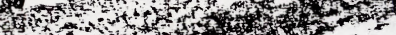
सt s.t. (1)

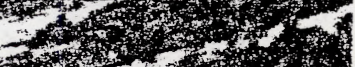

$\therefore-2$.

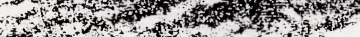

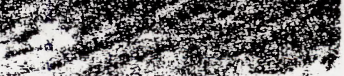
and 
$-2.26$ sheep'all mocking the bighom telemetry and sight, and it finally looked like Dan was going to get his shot. I hung back and framed him, the ram, and two ewes in the viewfinder of my. Nikon, then hit the shutter and hoped for the best as he fired the tranquilizer dart into one of the ewes The three sheep bolted across the rocks on

the theepslopécoverlooking the North

2. Larame River y to to

We found them th the head of Yankee Draw, about a mile from where Dan had darted the ewe, some three miles

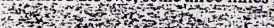

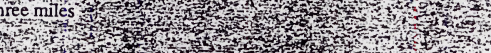

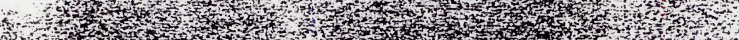

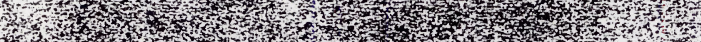

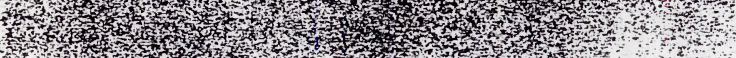
F

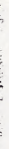

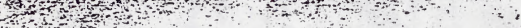

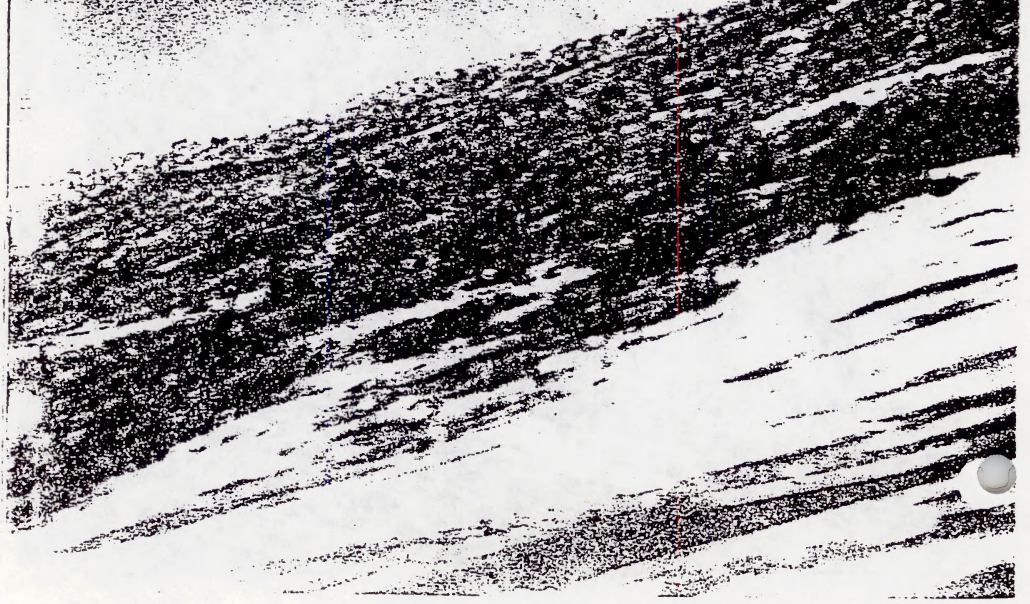




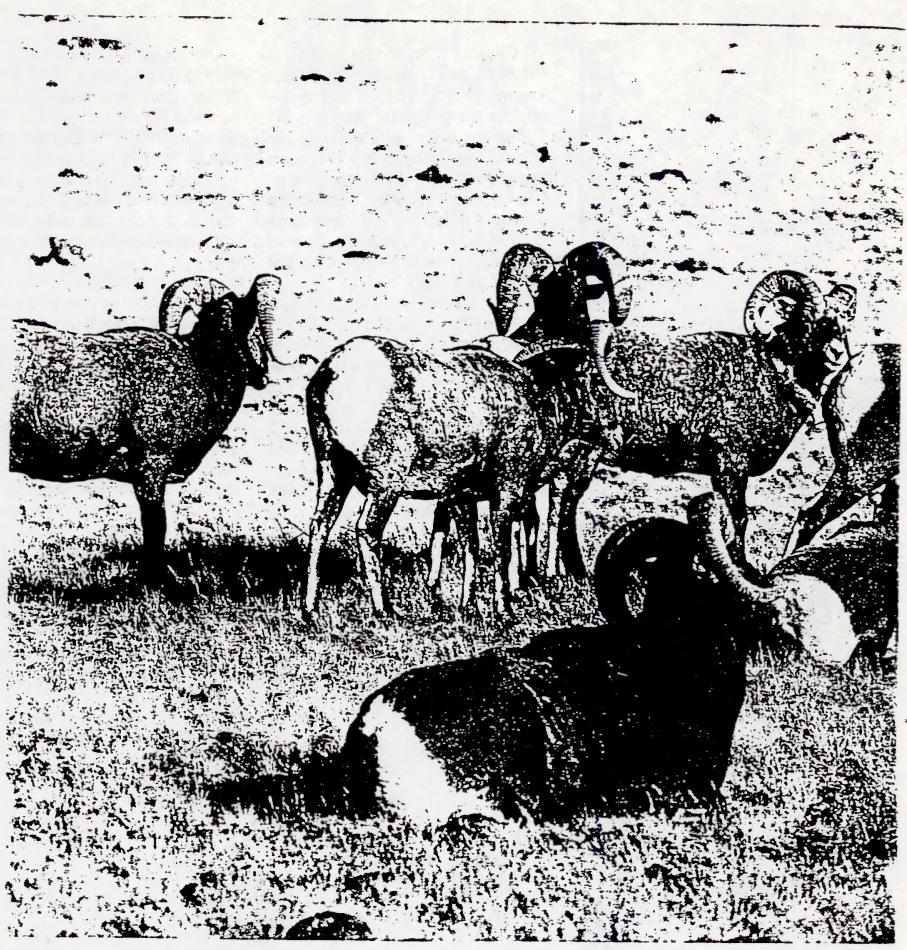

Fine diminance of a small number of rans in a bititem shetp population can ertisgerate tretetic pribiems in isoluted she'ep popstiantems.

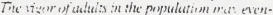
thull: ine affice est as a re'sult of intreteding

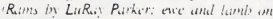

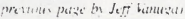

downstrean from the abandored town of Garret. Wioming. The two ewes and the ram uere beautiful in their light winter coats but tough to see aguinst the snow.

The ram and the wher ewe sook oft at our approat:. lean ing the: tallen companion. It want long betive weid

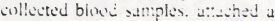

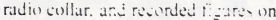

age. weight. and condition.

Dan Hengel has been studving six herds of sheep in the Laramie Peak area since July 3. 1989. for the Lniversity of Wyoming Cooperative Fishery and Wildlife Research Unit. Dan said our Liy of durting vver the weekend of $\mathrm{F} e \mathrm{~s}, 24-25$ wis a "ty pical" one.

"It cahes you furever to ger a shot. soen: like:" he said. 


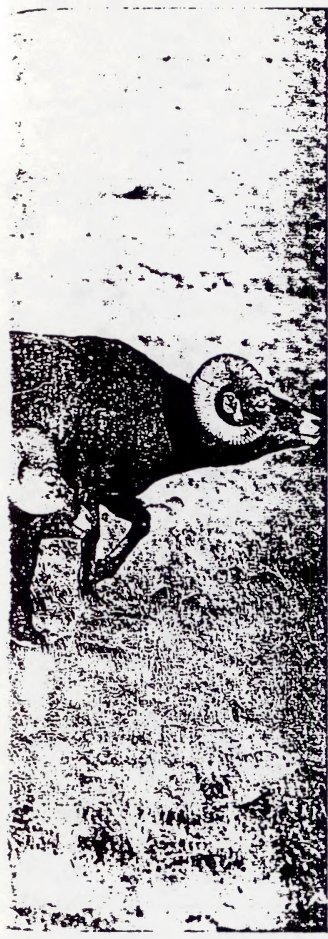

We hadrit seen a sing'e sheep the das betore, in an e'en more rugged area inhabited by another herd.

Halt of the time. Dan never gets a wher. Seven of the fourteen radio collars placed on the shep :o track their movements were hyltes on after the sheep had been captu:ad w ith a net gun fired out of a helicog:er in . August of $19 \times 9$.
"Chasing sheep (on the ground) is pretty tough." Dan said. "This is neat country geographically. Topographically speaking. it il kill you."

Bighorn sheep were native to the Laramie Peak area before they were extirpated in the nineteenth century. known as the Age of Exploitation among wildlife biologists and symbolized by the wholesale slaughter of American bison by hired hunters like Buffalo Bill Cody.

The Wyoming Game and Fish Department has transplanted $168 \mathrm{big}$ homs from the 1.000 -member Whiskey Mountain herd to the Laramie Peak area since 1964. The last group of twenty was transplanted in 1989 and collectively make up the Marshal herd. Five other herds have been established in the Duck Creek. Upper North Laramie, Lower North Laramie, Black Mountain, and LaBonte Canyon areas of Laramie Peak.

Bighom sheep transplants have been going on in Wyoming since 1934 when twenty sheep were moved from Flat Creek Canyon in Teton County to the Big Horn Mountains, said John Emmerich, a Wyoming Game and Fish Department biologist in Lander. The first bighorns were transplanted from Whiskey Mountain in 1949, Emmerich said.
Dan Hengel's study runs from 1989 to 1992. Thirty radio collars will allow him to collect data on seasonal movements of the bighorns and to follow them around and collect population data on lambing rates. survival rates. sex ratios. numbers of animals lost to predation. accidents, and disease. The study's other objectives include collecting data on seasonal diet and habitat use.

Ultimately. the study will try to determine how successful the transplanting of sheep to the Laramie Peak area has been. Preliminary population data indicate that the herd recently has been declining in numbers, Hengel said.

A population model used by biologists Joe Bohne and Rich Guenzel estimates the 168 transplanted animals should have grown to about 225 individuals. Hengel's low population estimate is 181, his high, 235.

Dan Hengel's toughest work is tracking the Duck Creek herd. So far, only two radio collars have been attached to ewes there, via the helicopter net gun technique.

"Finding them's one thing-getting up on 'em so you can get a shot's another." he said.

The ratio of lambs to ewes in the Duck Creek area has declined from

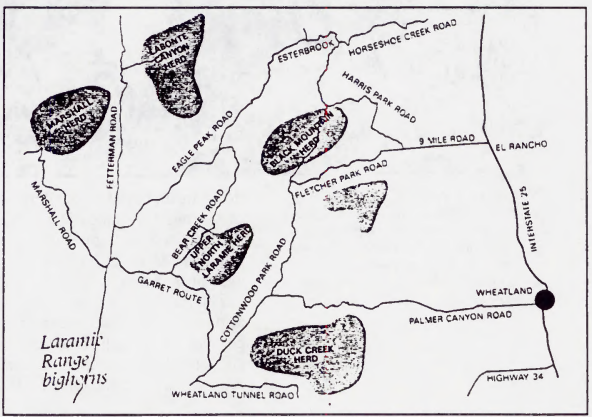




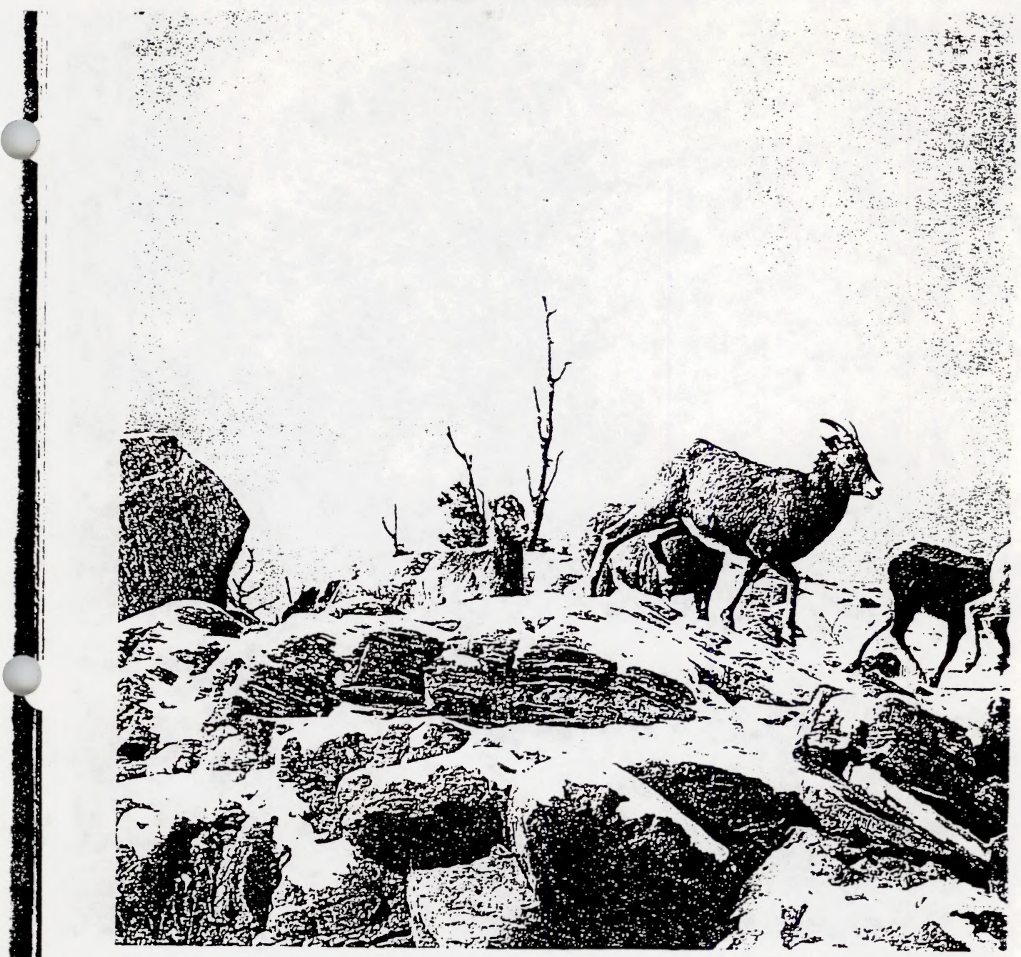

live lambs per ten ewes in June to about two lambs to ten ewes now. Dan swid. In the herd overall. it would be youd to see one lamb per ewe and a survisal rate of fitty to sis? percent instead of the fitten to twenti-fivepersent Dan now estimates

According to reports given at smpusia of the Vurthern Wild Sheep Council. transplunting bighurn ateep ha become a common method a) trs (1) increase sighom weephers in the
Rocky Moun wain region. Populations of Rock! Mounwin bigt:m sheep have steadily decreased sinse the turn of the century due to the sovid and agricultural activities of mat.. deterioration of habitat and range. and various dise:tess. according to researcher Term. Spraker

Not much intomation is wailable on what leads to success or iutlure in bighwrn sheep transplant?

But in an earlier stud: if everet bighom herds near Encampment. Wyonuing. John Coo' concluded that the main limiting factor un bighorn populations is the availability of quality forage. particularly during the summer lambing season. Juveniles were most vulnerable to a lack of quality food. Infrequent dispersal and specific habitat requirements also limit sheep populations. Researchers agree fire suppression during the last century has protanl: wornened torage and habitat 


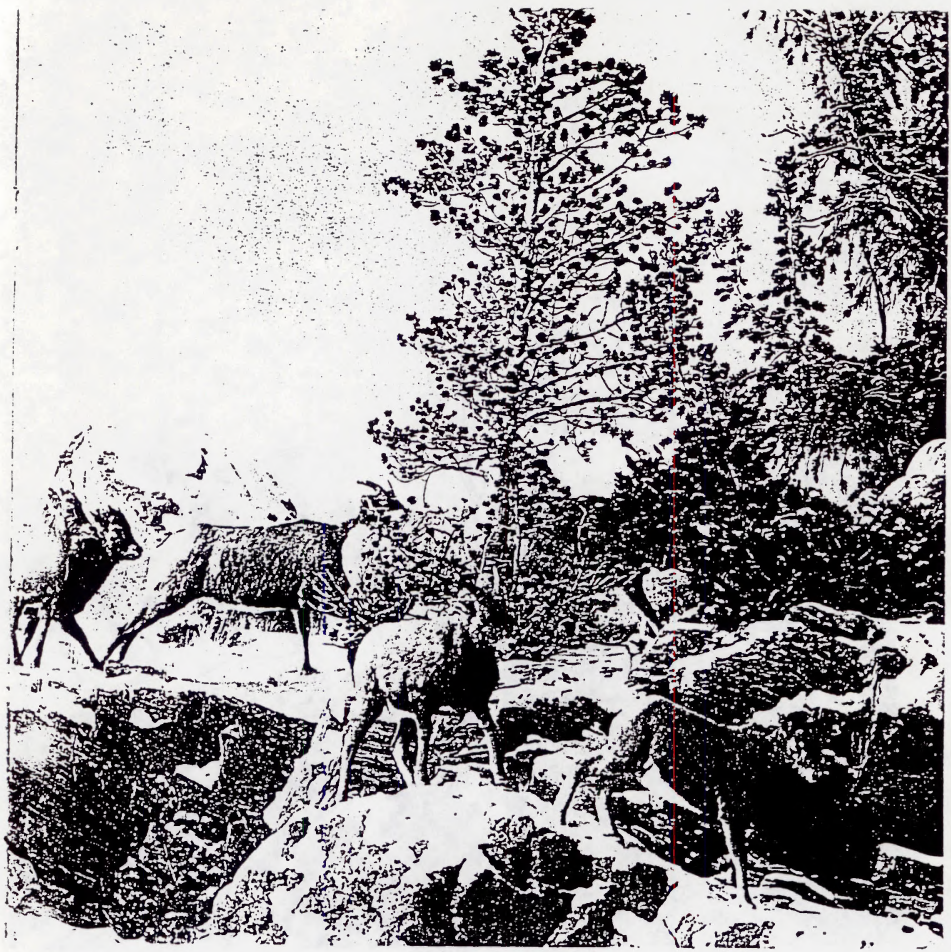

conditions for bighorns.

The timing of lamb births and the g-zen-up of annuai gresses is critical ar. musi oceur simatonously to mixinsze lanib survit2:. Cook hy pothesized that genetic difterences maty be among the redions bighorns hat e disippeared trom many low-elevation in as where the: thited during the r:aesenth eentur: The earlier biy-

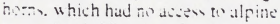

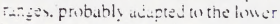

altitudes by timing their birth pulies with the annual green-up of grasses. making lots of hizh-qualin tornge available for lactuting ewes when the needed it most to produce milk for hungry lambs. But transplanted bighorns from alpine ranges such as Winiske: Mountuin muy be less adapted to the dr. tow-elesution range's whers they are released than were nineleant:esntury shecp

Althugh forse: mat be ahunkart
The relationsis: sa: seen births and deaths determines the "... Zrouth or decline in any populanon. Tiz e.th and productiviry of the iemale is gener... ' Atit ker to this relationship.

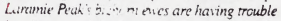

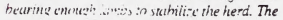
chestion is: $\mathrm{t}$ : 


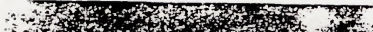

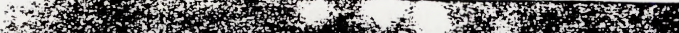

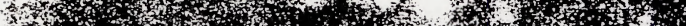

(1)

if

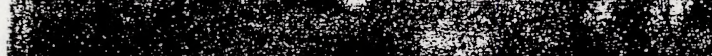

$x^{2}$

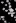

Ald

to

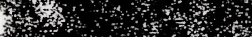

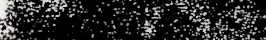

and

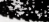

$\therefore$ (n)

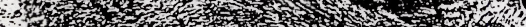

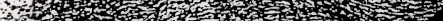

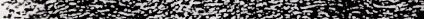

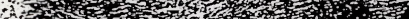

ton

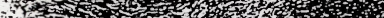

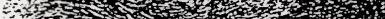

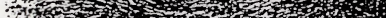

a.

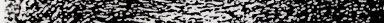

A6.

30.4:

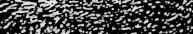

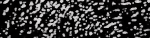
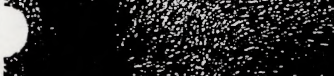

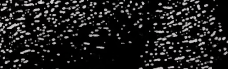

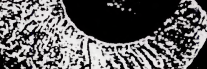

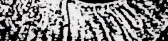

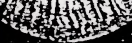

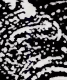

$=0$

$\therefore$;

\section{ㄴ:4z}


the specific plants needed to meet bighorn nutrient requirements mas not. Cook found that only five to fifteen percent of plants met the needs of adult ewes with lambs.

Precipitation is critical to plant growth and sheep survival; Cook predicts that a minimum of sixteen inches per year is needed. and that levels less than ten inches per year will prohibit the successful establishment of a transplanted herd.

Hengel. Cook. and other researchers agree on many of the criteria a potential transplant site should have in order to establish successful bighorn herds. Two primary limiting factors affecting transplant success are escape terrain and high-quality summer forage.

Transplant sites should have average slopes of thirty-five to forty percent or more; some studies show bighoms like slopes two to three times steeper. Sheep like rock outcrops ten to 100 feet high and some larger rock walls of 160 feet or more, open ridges which blow free of snow in the winter, and open travel corridors from one seasonal habitat type to another. Sheep prefer particularly rugged escape terrain for lambing and raising lambs, but water also must be available through late summer.

Why were the sheep extirpated from their historic range? Have these problems been corrected? Can a particular reintroduction site support a minimum of fifty transplanted sheep to establish a viable population? These are critical questions to answer. if possible. before reintroducing sheep, Hengel said.

Cook said forested a reas should be avoided because sheep prefer open habitats with good visibility. Bighorns tend to cluster around isolated "islands" of suitable habitat within larger areas of unsuitable habitat. But concentrating sheep facilitates the spread of disease and increases competition for high-quality forage. Hengel added that competition with other wild ungulates and domestic livestock should be avoided, where possible.

Cook listed several management recommendations for Rocky Mountain bighorn sheep. Controlled burns in- crease forige quality and siould te dine on lumbing-nursen ares-p preterahly within 200 tw 300 yards or rugges escipe terrain to benefit summering: shesp. The ided is to decreane sagebrush. increase forbs, and maintain deviduous browse

Detorestation may actually help bighorns. but clearcuts should oe near excupe terrain.

Techniques of transplanting should be curefully plunned to place sheep in areas near the most suitable habitat and to spread sheep throughout a potential range. Cook wrote. Sheep transplunted

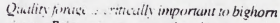
vicup. Primur : stazers. the sheep require picun uf aras. ... stet? escipe coner in order it iruyper. S. u-tree slopes or windswept ridses are crit... ito thenvinter suritial. (Ram wht swe bi LaR.y Parker).

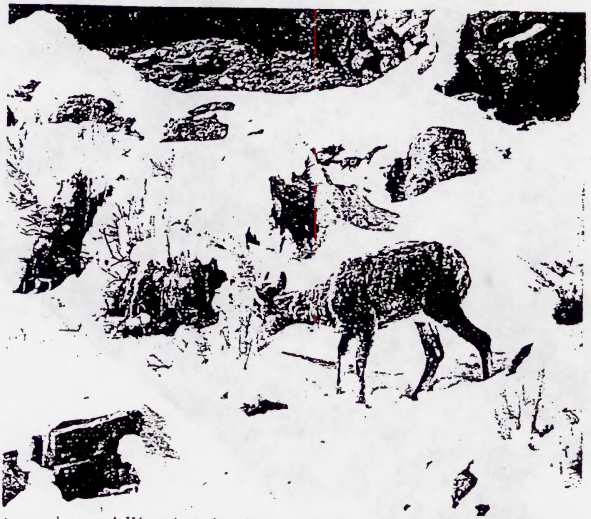

to southcentral Wyoming sites have been reluctunt to disperse ver far from release sites. and some have failed to occupy better ranges than those they colonized. Therefore. Cook said nuultiple release sites should be considered. This would encourage bighorn migrations botween alpine summer ranges and low-elevation winter ranges. Both size and distribution of bighem herd, can be increased with multiple releuse siter.

Drug treitment of diseases such as lunguorm and a ummer feeding program to supplemsnt diets when ewes are lactating should be considered, Cook said.

The jury is still out on the success of the Larum 2 Peak transplant. until sometime at:ar Dan Hengel's field work is completed in 1992 and he's analyzed the population data.

But whate? the results, it's certain that simply trisplanting bighom sheep ti) a site. eten ne they historically occupied. isni anough to ensure their vuccess A bighorn reintroduction requires careti. management. $=\square$

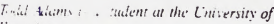
H. rmins 


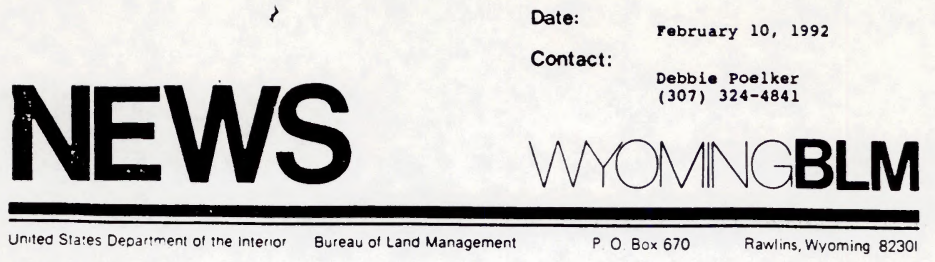

The Bureau of Land Management's Bud Holbrook, Area Manager of the Great Divide Resource Area, Rawlins, Wyoming, announced the receipt of a check for $\$ 7,150$ from the wyoming Chapter of the Foundation for the North American wild sheep (FNAws). The money will provide needed financial assistance to an interagency effort to use prescribed burning for improvement of Rocky Mountain bighorn sheep habitat in the Laramie Peak area of east central Wyoming.

Rocky Mountain bighorn sheep were reintroduced into the Laramie Peak area in 1964 . As of June 30, 1989, 168 bighorn sheep from the Whiskey Mountain herd near Dubois, Wyoming, have been transplanted. In spite of these releases, the Laramie Peak herd is having difficulties reestablishing itself in this historic bighorn sheep habitat.

The Laramie Peak Bighorn sheep Technical Comnittee, comprised of the Wyoming Game and Fish Department, University of Wyoming Cooperative Fish and Wildife Research Unit, U.S. Forest Service, and the Bureau of Land Management, recommends habitat manipulation through prescribed burns to improv the herds health and vigor. Holbrook says the committee is grateful to FNAwS for their generous contribution to aid the sheep. FNAwS's purpose, as stated in their articles of incorporation, is "to promote the management of, and to safe guard against the extinction of all species of wild sheep native to the continent of North America." 


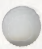

0

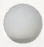




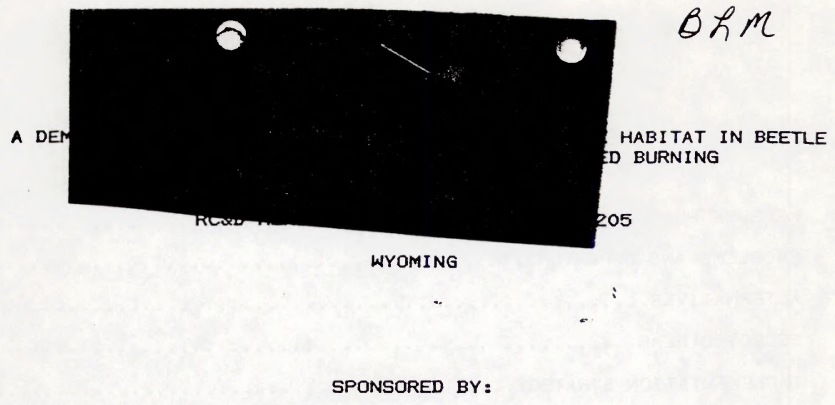

SOUTHEASTERN WYOMING RESOURCE CONSERVATION AND DEVELOPMENT COUNCIL LARAMIE RIVERS CONSERVATION DISTRICT WYOMING GAME AND FISH COMMISSION BUREAU OF LAND MANAGEMENT U.S. FOREST SERVICE FOUNDATION FOR NORTH AMERICA WILD SHEEP, WYOMING CHAPTER SOUTHEASTERN WYOMING RCSD AREA

Prepared with assistarice from the U.S. Defartment of Agriculture, Soil Conservation Service

Casfier, Wyaming Fetiruary, 1992

Frepared under the authority of section 1528-1538 of the Agriculture arid Food Act of 1981 (F.L. $97-98$ ) 


\section{TABLE OF CONTENTS}

MEASURE FLLAN AGREEMENT $\ldots \ldots \ldots \ldots \ldots \ldots \ldots \ldots \ldots \ldots \ldots \ldots \ldots \ldots \ldots \ldots$

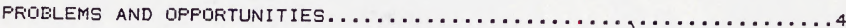

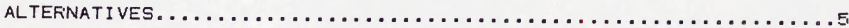
SELECTED PLAN. ................................

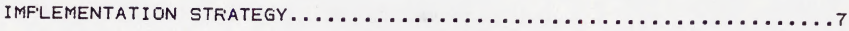

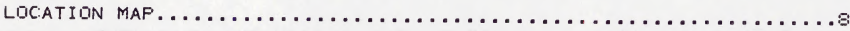
COST ESTIMATES................................

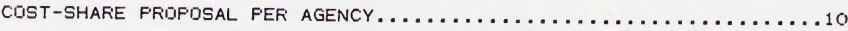

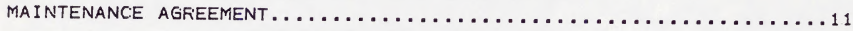
COMFLIANCE WITH CIVIL RIGHTS ACT. . . . . . . . . . . . . . .

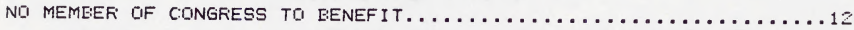
AGREEMENT REQUIRED TO DQLIGATE FUNDS $\ldots \ldots \ldots \ldots \ldots \ldots \ldots \ldots \ldots \ldots \ldots$ SIGNATUFE ELGCK............................... 
Through the request of the S.E. Wyoming FC\&D and the Laramie Fivers Conservation District, and the cooperative efforts of the sponsors and the Soil Conservation Service (SCS), this mutually agreeatile FiC\&D Measure plan has been confleted. This RCeD Measure has been adopted by the S.E. Wyoming FCSD Couricil and included in the area filan as a mearis to accomplish objectives for the area. 


\section{PROBLEMS AND OPPORTUNITIES}

This froject is located within the Laramie Feak Wildlife Habitat Area in Albariy County, Wyoming (Sec. $31, T .24 N$., R. 71 W.). The location will the more specifically called the Duck Creek - Split Rock area.

Focky Mountain bighorn sheep (Dvis canadensis canadensis) were reintroduced into the Laramie Feak area of east central Wyoming in 1964. To date, 168 bighorn sheep have been relocated into this area. In spite of these transfilant, the Laranie Feak sheep herd appears to tie declinirig.

One serious froblem, identified, facing the bighorn sheep and other wildife in this area is the ericroachment of ponderosa pine into historical sheep habitat. Fine stands reduce habitat quality by depleting foraging areas and by creating an impediment to the sheep, farticularly when trees divide escape terrain arid foraging areas. This is the case on Split Fock Mountain.

Mariy of the trees on Split fock Mouritairı have tieen killed ty the mountain fine tieetle. Due to the rugjed terrain, it is not possible to harvest the dead trees. Eeetle killed trees may begin to fall after five years, defiending upon wirid, moisture, soil and topography. After these trees have fallen they will create an even greater hindrarice to the sheep or the ground, than staniding trees. The trees on Split Fock Mountain have been standirig dead for three years and longer arid some have already fallen.

If these trees are rict removed, the chances of an uncontrollabile wildfire is greatly increased by the high fuel load. Ey removing the trees, visibility for faraging sheep will be increased, thus reducing the time and energy spent in a state of alert. Studies have showri that sheep feed more efficiently in the atisence of trees.

To cut and burn tieetle killed trees in iraccessible areas to beriefit wildife has riever tieen attempted tefore in this part of Wyoming, if at all. In the Laramie Feak Area there are vast acres of tieetle killed trees inaccessitule to harvesting, which are especially hindering to bighorn sheep survival. If this project firoves successful, this method of tree removal may become widely used as a mariagernent tool for improving wildife habitat in beetle kill areas.

The burn area will be closely monitored for changes irı wildife use and vegetation quantity and quality. Vejetative monitoring cages have already been distributed throughout the proposed burn area, having been slung ty helicopter in September 1991 into this remote arid rugged area. 


\section{ALTERNATIVES}

1. Use fire as a tool to imfrove forage quality while leaving stariding, beetle killed trees to eventually fall riaturally.

2. Fall standiris, teetle killed trees ty mechanical mearis, then ust fire as a tool to "open" the beetle-kill areas, and improve vegetation quality and quaritity.

3. Do nothing - let nature take its course. 


\section{SELECTED PLAN}

Alternative number two has been selected. The proposed action is to frescribe burn afpraximately 400 acres of sagebrush/grass, mountain shrubs, young fonderasa pine and mature, beetle killed ponderosa fine. The planned turn will be in a mosaic pattern within a 1500 acre area.

The followirig results are anticipated:

1. Improve forage quality and quantity for bighorn sheef, elk and mule deer by impraving grass/forb froductian, increasing new palatable shrub production and reducing stagriant shrub growth.

2. Imprave bigharn sheep feedirig sites adjacent to escape terrain and nursery areas.

3. Feduce youris ponderasa pine regeneration in the burn units to provide visual migration corridors for wildife to escape cover or habitat not currently used.

4. Provide uneven - aged forage classes and edge effect by conducting mosaic fiatern frescribed burns.

5. Improve wildlife habitat and increase wildlife numbers to provide quality wildife experiences for the general public wishirig to use the 31,000 acre Laramie Feak Wildife Habitat Area. 
The desigri, layout arid implementation of this project will te dane tiy the Wyomirig Game and Fish Department, the Bureau of Land Mariagenerit and the U.S. Forest Service.

The project will be completed in the following sequence:

1. Fre-turn timber cutting - appraximately 27 acres of mature, beetle killed ponderosa pine will be knocked down during the late winter of 1992 :

2. Frescritied turn - appraximately 400 acres will be burried in the early spring of 1992 . This controlled burn will be in a mosaic pattern over a 1500 acre area. A Helicopter/Helitorch will tie used during the burn.

3. Fast-tiurn manitaring - the above-riamed agencies will monitor the results of this project on a continuing basis.

Transects will bie sampled on burned and unturned sites to determine percent canopy cover, vegetation height and composition. Forage will be ciliped and analyzed to determine crude protein and total digestible rutrients. Wildife species/behavior/numbers will tie monitored accordingly. 


\section{A DEMONSTRATION TO EVALUATE AND IMPROVE WILDLIFE HABITAT IN BEETLE KILLED PONDEROSA PINE BY USING PRESCRIBED BURNING}

\section{Cost Estimates}

\section{TIMBER CUT:}

Helicopter: (breakdown in froposal) SUB-TOTAL \$6985.00

Fersoniel: 5 people $\times \$ 12.00 \times 10$ hrs/day $\times 5$ days: $\$ 3000.00$

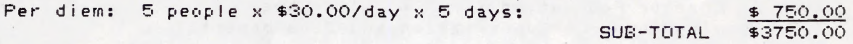

TOTAL FOR TIMEER CUT $=\$ 10,735.00$

\section{BURN :}

PERSONAL \& PER DIEM:

Ta blackline and burn: 15 people $\times \$ 12.00 / h r \times 10$ hrs/day

$$
\times 5 \text { days: } \$ 9000.00
$$

Per diem: 15 people $\times \$ 30.00 \times 5$ days: $\$ 2250.00$

Haldirig force/postburn: $Z$ people $\times \$ 12.00 / h_{1} \times 10$ hrs/day $x 2$ days:

Fer diem: 2 feople $x \$ 30.00 / d a y \times z$ days:

$\$ 120.00$

Travel experise:

SUE-TOTAL $\$ \frac{\$ 450.00}{12,300.00}$

\section{HELICOPTER:}

Helicopiter

Helitareh fuel

$\$ 1375.00$

Fuel truck

$\$ \$ 00.00$

Fer diem pilot \& truck driver

SUE-TOTAL $\frac{\$ 600.00}{\$ 3000.00}$

Helicopter

SUE-TITAL \$7150.00

TOTAL OF BURN $=\$ 22,450.00$ 


\section{TOTAL COST PER AGENCY}

Wyoming Game and Fish Departmerit

U. S. Forest Service

Eureau of Land Mariagement

Wyoming Chapter Fouridation for N.A. Wild Sheep

S.E. Wyoming Resource Conservation and Development 1

\begin{tabular}{rr}
$\$ 10,650.00$ \\
& 750.00 \\
& $7,650.00$ \\
& $7,150.00$ \\
& $6,985.00$ \\
\hline Total $\$ 33,185.00$
\end{tabular}

1 Fiefers to affurapiation that would come to the southeastern W: FC:D through the Wyoming SCS/RCsD budget. 


\section{MAINTENANCE AGREEMENT}

Fraject maintenance will tie the responsitility of the Eureau of Land Management.

Maintenance includes ferformance of work and providing the materials to prevent the deterioration of practices andlor repair damase to or refiacenent of the practice if ane or more of its components fail. This iricludes thoth routine and recurring needs. Damages to completed practices caused by normal deterioration, drought, flaoding caused by rainfall in excess of designi, or vandalism is considered maintenance.

The undersigned will tie respansible for maintenance.
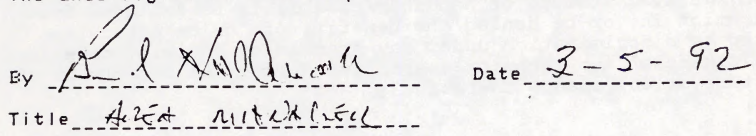


\section{COMPLIANCE WITH CIVIL RIGHTS ACT}

The RC\&D program will be conducted in compliance with the nondiscrimination provisions as contained in Title VI and VII of the Civil Rights Act of 1964 as amended, the Civil Rights Restoration Act of 1987 (Pub. Law 100-259) and other nondiscrimination statutes; namely, Section 504, of the Rehabilitation Act of 1973, Title IX of the Education Amendments of 1972, the Age Discrimination Act of 1975 and in accordance with the regulations of the Secretary of Agriculture (7CRF-15, Subparts A \& B) which provide that no person in the United States shall, on the ground of race, color, national origin, age, sex, religion, marital status, or handicap/disability be excluded from participation in, or be denied the benefits of, or be otherwise subjected to discrimination under any program or activity receiving federal financial (or technical) assistance from the Department of Agriculture or any agency thereof.

\section{NO MEMBER OF CONGRESS TO BENEEIT}

No member of or delegate to Congress, or resident commissioner, shall be admitted to any share or part of agreement, or to any benefit arising from it. However, this clause does not apply to this agreement to the extent that this agreement is made with a corporation for the corporation's general benefit.

\section{AGREEMENT REQUIRED TO OBLI GATE FUNDS}

This is not a fund-obligating dosument. Financial and other assistance to be furnished by SCS in carrying out the work in this plan is contingent on the appropriation of funds for this purpose. A separate agreement will be entered into between SCS and sponsors before either party initiates work involving funds of the other party. Such an agreement will set forth in detail the financial and working arrangements and other conditions that are applicable to the specific
improvements to be installed. 
SIGNATURE BLOCK

A DEMONSTRATION TO EVALUATE AND IMPROVE WILDLIFE HABITAT IN BEETLE KILLED PONDEROSA PINE BY USING PRESCRIBED BURNING

This project measure, implementation and proposed fundiriz have beer reviewed ard affiroved.

The plan may be amended, revised or terminated by mutual agreement of the parties hereto.

SOUTHEASTERN WYOMING FEED COUNCIL:

BY Bud U Dower

DATE $2-20-92$

TITLE Climes.

LARAMIE RIVERS CONSERVATION DISTRICT:

EYck

DATE $-22 /=2 / 2=$

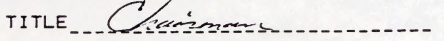

WYOMING GAME AND FISH COMMISSION:

Er Argue Deter

DATE $-3 / 2 / 2 / 2 z$

TITLE Director

BUREAU OF LAND MANAGEMENT:

BY

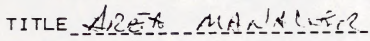

USS. FOXIEST SERVICE:

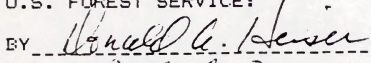

DATE

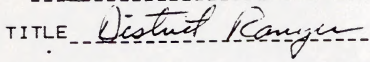

FOUNDATION OF NA. WILD SHEEP, WYOMING CHAPTER:

vv-Dau lottery

DATE $3-6=92$

TITL_Diunetion

USDA - SNIL CONSERVATION SEFVICE:

IIIE State Concedeteiniat

date Maceh-1,1,199.

$-13-$ 


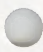

0

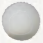




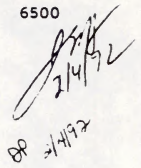

Myron J. Wakkuri

Project Coordinator

USDA Soil Congervation Service

1302-B 9th Street

Wheatland, Wyoming 82201

Dear Mr. Wakkuri:

Thig grant proposal would provide needed financial asgistance to an interagency effort to improve Rocky Mountain bighorn sheep habitat in the Laramie Peak area of east central Wyoming. Cooperating agencies in the "Laramie Peak Bighorn Sheep Technical Committee" and this project include Wyoming Game and Fish Department, University of Wyoming Cooperative Fishery and Wildlife Research Unit, U.S. Forest Service and the Bureau of Land Management. Funds, equipment and personnel will be provided by the above mentioned agencies, and additional financial assistance from scs is requested to administer the execution of this project.

Rocky Mountain bighorn sheep (Ovig canadensis canadensig) were reintroduced into the Laramie Peak area of east central Wyoming in 1964. Ag of June 30 , 1989, 168 bighorn sheep have been transported from the Whiskey Mountain herd near Dubois, Wyoming and released near Laramie Peak. In spite of these transplants, the Laramie Peak sheep herd appears to be declining. The Wyoming Game and Fish Department has set the strategic plan objective for the Laramie Peak sheep herd at 500 animals and the strategic harvest objective at 24 rams annually. However since the first hunting season in 1969, no single year harvest has exceeded 7 rams. The current population for the Laramie Peak herd is estimated at 227 sheep and 50-60 sheep for the Duck Creek-Split Rock subherd. Through habitat manipulation in the way of prescribed burns, and the removal of beetle killed pine, the committee hopes to improve herd health and vigor.

There is an element of urgency in that the trees need to be cut as soon as possible in preparation for a late winter/early spring burn. If scs cannot provide funding or if the total cost for helicopter time is greater than what is estimated here, the Wyoming Cooperative Fishery and Wildlife Research Unit will pay the cost from big horn sheep project money.

If scs does provide funding for this project, one option might be that the scs directly pay the helicopter company. Another option is that the scs enter into a reimburgable agreement with the Bureau of Land Management. Deborah Poelker of this office sent the forms for this agreement to your office last month. 

Please contact Deborah Poelker at (307)324-4841 with any questions or
comments.

\author{
Sincerely, \\ /s/ Bud Holbrook \\ Area Manager \\ Great Divide Resource Area
}

DPOELKER:gs: 1-31-92:|multi |wakklet.dp 


\title{
APPENDIX II
}

\section{Vegetation/Habitat Types}

\author{
Major Range Sites \\ Precipitation Zone \\ Associated Wildlife Habitat Type
}


0

0

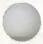


ch

Seltbuah

in shrub

\section{Greaserwood}

All Sandy

Loamy

Clayey

Shallow Sandy

Shallow Loamy

Sands

7-9 Sallne Lowland

7-9 Saline Upland
Western wheatgrass Phlox

Thickspike wheatgrass Buckwheat

Bluebunch wheatgrase Lupine

Sandberg's bluegrass Pussytoes

Indian ricegrass Anter

Threadleat sedge Milkvetch

Needle-sind-thread

Prairie junegrase

Sand dropeeed

Prairle sandreed

Plains reedgrass

King-spike fescue

Oniongrass

Columbia needlegrase

Basin wildrye

Mountain brome

Bottlebrush squirreltal

doho fescue

Sandberg's bluegrass

Indian ricegrase

Inlsnd saltgrasa:

Alkall sacaton

Thicksplke wheatgras:

Bottlebrush squirretal

Basin wildrye

Nuttali's alkaligrase

Indian ricegrase Bottiebrush equirreltall

Sandberg's bluegrass

Western wheatgrass

Bluebunch wheatgrass

Bluebunch wheatgrase

Sandberg's bluegrase

KIng-spike tescue

Idaho fescue

Mountain brome

Threadleaf sedge

Bottlebrush squirreltail

Columbia needlegrass

Indian ricegrass

Western wheatgrasa

Ross' sedge
Broedieaf Trees

15-19 Aspen

Columbla needlegrass

Elk sedge

Bromegrasses

Ryegrasses

Sedgee

Kentucky bluegrase

Blg bluegras

Idaho teacue

Conifer
10-14 No major range sito Bluegrasses

15-19 identified
Sedges
Mountain brome

Idaho fescue

Western wheatgrass

Elk sadge

Needlegrass

Pinegrase
Indien paintbrush

Piains prickly peser

Penstemon

Vetch

Black sagebruah

Big sagebrush

Douglas rabbitbrush

Aubber rabbitbrush

Broom snakeweed

Sllver sagebrush

Shadecale

Spiny hopaage

Wintertat

Birdatoot sagebrush

Horebruah

Skunkbush sumsc

Yuces

Snowberry

Bitterbruah

Purah seepweed

Dock

Pniox

Biscultroot

Piaina prickly pear

Pepperweed

Globemallow

Milkvetch

Alysoum

Onion

Biecuitroot

Onion

Woody aster

Phlox

Penstemon

Buckwheat

Penstemon

Buckwheat

Weatern yarrow

Violet

Lupine

Cinquetoll

Arnica

Balsamroot

Buckwheat

Columbine

Geranlum

Eltweed

Licoricerool

Yarrow

Amica

Cinquetoll

Strawbern

Lupine

Waterleat

Amica

Balsamroot

Penstemon

Bedstraw

Vetch

Hawksbeard

Western yarrow

Aster

Mountain pee

Wintergreen
Black greasewood Big eagebrush

Gardner's saltbuah

Winterfet

Bud sagebruah

Dougles rabitbrush

Birdstoot segebrush

Aubber rabbitbruan

Gardner's ealtbush

Bud sagebrush

Birdetoot sagebrush

Greaseowood

Shadecale

Horiabruth

Winterta:

Antelope bitterbruah

Snowbery

Big sagebruah

Skunkbush sumac

Aubber rabbltoruth

Silver sagebrush

Common chokecherry

Widd rose

Ceanothus

Serviceberry

Western enowberry

Currant

Mountain mahogany

Quaking aspen

Snowberry

Oreson grape

Creeping juniper

Buftaloberry

Currant

Douglas-fir

Wild roes

Big sagebrush

Limber pine

Lodgepole pine

Ponderosa pine

Snowberry

Common chokecherr

Quaking aspen

Antelope bitterbrush

Creoping juniper

Grouse whortieberny

Oregon grape

Douglas-fir

Englemenn spruce
Greasewood-sagebrush

Big sagebrush-rabbitbrush

Yucca-mixed grass

Black sagebrush

Silver asgebrush

Tall sagebrush

Sagebrush-mixed grass

Greasewood-eagebrush

Saltbush steppe

Greaserwood

Mixed shrub

Saltbush Steppe

Mountain mahogany Bitterbruah-sagebrush

Mountain shrubland

Aspen woodland

Aspen-conifer wood
Limber pine woodisnd Umber pine/ Juniper woodiand Aspen-conlfer woodland Douglas-fir torest Lodgepole pine forest

Larsmie Peaks rockland 
0

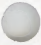

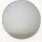




\begin{tabular}{|c|c|c|c|c|c|c|}
\hline Vegetethe TYpe & $\begin{array}{l}\text { Precipl- } \\
\text { tation } \\
\text { Zone } \\
\text { (inchee) }\end{array}$ & $\begin{array}{c}\text { Melor } \\
\text { Range sttee' }\end{array}$ & Gresese/Graeslikes & Forbe & Ehruba/Trees & $\begin{array}{l}\text { Aseociated midilfe } \\
\text { Habitet Type }\end{array}$ \\
\hline Grass & $10-14$ & $\begin{array}{l}\text { Shallow Clayey } \\
\text { Impervious Clay }\end{array}$ & $\begin{array}{l}\text { Western wheatgrass } \\
\text { Thicksplke wheatgrass } \\
\text { Bluebunch wheatgrass } \\
\text { Streambank wheatgrass } \\
\text { Needle-and-thread } \\
\text { Sendberg's bluegrass } \\
\text { Indlan ricegrase } \\
\text { Blue grama } \\
\text { Threeawn } \\
\text { Prairie junegrass } \\
\text { Thresdieaf sedge } \\
\text { Bottlebrush squirreltail }\end{array}$ & $\begin{array}{l}\text { Blscultroot } \\
\text { Phlox } \\
\text { Buckwheat } \\
\text { Pusaytoes } \\
\text { Aoter } \\
\text { Woody aster }\end{array}$ & $\begin{array}{l}\text { Big sagebiush } \\
\text { Dougias rabbltbrush } \\
\text { Birdsfoot sagebrush } \\
\text { Biack sagebrush } \\
\text { Threetip sagebrush } \\
\text { Gardner's saltbush } \\
\text { Wintertat } \\
\text { Bud sagebrush }\end{array}$ & $\begin{array}{l}\text { Shortgrass } \\
\text { Sagebrush-mixed shrub } \\
\text { Sagebrush-mixed grass }\end{array}$ \\
\hline Meadow/Riparian & All & $\begin{array}{l}\text { Subirrigated } \\
\text { Saline Subirrigated } \\
\text { Wetland } \\
\text { Lowland }\end{array}$ & $\begin{array}{l}\text { Thickspike whestgrass } \\
\text { Kentucky bluegrass } \\
\text { Tutted hairgrass } \\
\text { Mat muhly } \\
\text { Ruahes } \\
\text { Sedges } \\
\text { Alkall sacaton } \\
\text { Inland saitgrass } \\
\text { Cartail } \\
\text { Bulrushes } \\
\text { Spikesedge } \\
\text { Basin wildrye } \\
\text { Redtop } \\
\text { Mannagrases } \\
\text { Brookgrass }\end{array}$ & $\begin{array}{l}\text { Thistie } \\
\text { Iris } \\
\text { Lupine } \\
\text { Mints } \\
\text { Horsetall } \\
\text { Aster } \\
\text { Volets } \\
\text { Buttercup } \\
\text { Sea milkwort } \\
\text { Arrowgrass } \\
\text { Plantain } \\
\text { Goldenrod } \\
\text { Cinquetoil }\end{array}$ & $\begin{array}{l}\text { Rubber rabbitbrush } \\
\text { Narrowleat } \\
\text { cottonwood } \\
\text { Waterbirch } \\
\text { Dogwood } \\
\text { Common chokecherry } \\
\text { Currant } \\
\text { Shrubby cinquefoll } \\
\text { Willow } \\
\text { Silverberry } \\
\text { Wild rose } \\
\text { Aspen } \\
\text { Buffaloberry } \\
\text { Hawthom }\end{array}$ & $\begin{array}{l}\text { Aiparian grassiand } \\
\text { Aspen riparlan woodland } \\
\text { Cottonwood floodplain } \\
\text { Wliow/waterbirch floodplain } \\
\text { Wetland } \\
\text { Subirrigated meadow } \\
\text { Saline subirrigated meadow }\end{array}$ \\
\hline Juniper & $10-14$ & Shallow Broake & $\begin{array}{l}\text { Mutton bluegrase } \\
\text { Western wheatgrass } \\
\text { Threadleaf sedge } \\
\text { Bluebunch wheatgrass } \\
\text { Idaho fescue } \\
\text { Indian ricegrass } \\
\text { Green needlegrass } \\
\text { Needle-and-thread } \\
\text { Thickspike wheatgrass } \\
\text { Prairie junegrass }\end{array}$ & $\begin{array}{l}\text { Indian paintbrush } \\
\text { Lerkspur } \\
\text { Ponstemon } \\
\text { Goldenweed } \\
\text { Aster } \\
\text { Buckwheat } \\
\text { Stonecrop }\end{array}$ & $\begin{array}{l}\text { Utah junlper } \\
\text { Rocky Mountain } \\
\text { juniper } \\
\text { Big sagebrush } \\
\text { Winteriat } \\
\text { Low rabbitbrush } \\
\text { Antelope bitterbrush } \\
\text { Mountain mahogany }\end{array}$ & $\begin{array}{l}\text { Utah juniper woodland } \\
\text { Mountain shrubland } \\
\text { Utah juniper woodland- } \\
\text { Limber pine woodland }\end{array}$ \\
\hline Rockland. & $\begin{array}{r}10-14 \\
15-19\end{array}$ & $\begin{array}{l}\text { Igneous } \\
\text { Shallow Igneous }\end{array}$ & $\begin{array}{l}\text { Prairie junegrass } \\
\text { Creeping wheatgrase } \\
\text { Thickspike wheatgrass } \\
\text { Griffith wheatgrasa } \\
\text { Bluebunch wheatgrass } \\
\text { Idaho fescue } \\
\text { Onespike danthonla } \\
\text { Slimstem muhly } \\
\text { Mountain muhly } \\
\text { Columbia neediegrass }\end{array}$ & $\begin{array}{l}\text { Penstemon } \\
\text { Pusaytoes } \\
\text { Biscuitroot } \\
\text { Phlox } \\
\text { Cinquefoll } \\
\text { Balaamroot } \\
\text { Yarrow } \\
\text { Aster } \\
\text { Stonecrop }\end{array}$ & $\begin{array}{l}\text { Rocky Mountain } \\
\text { juniper } \\
\text { Limber pine } \\
\text { Big sagebrush } \\
\text { Creeping juniper } \\
\text { Antelope bitterbrush } \\
\text { Snowberry } \\
\text { Black sagebrush } \\
\text { Currant } \\
\text { Oceanspray }\end{array}$ & Laramie Peaks rockland \\
\hline Berren & AlI & $\begin{array}{l}\text { Badiand } \\
\text { Rock Outcrop } \\
\text { Barren } \\
\text { Steep Stope } \\
\text { Shaie }\end{array}$ & \multicolumn{3}{|c|}{$\begin{array}{l}\text { If vegetation is present at all, most of the plant specles associated } \\
\text { with the wasto subtypes In the RMP ares are those associated with the } \\
\text { shortgrass, sagebrush, mountain shrubs, or juniper types. } \\
\text { Laramie Peaks rockland }\end{array}$} & $\begin{array}{l}\text { Limber pine woodland } \\
\text { Mountain mahogany } \\
\text { Badland }\end{array}$ \\
\hline
\end{tabular}

i SCS aita identification 
0

0

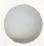


O

0

O 
0

0

0 


\section{APPENDIX III}

Laramie Peak HMP Species List

Common Species

Threatened/Endangered Species

Species of Special Concern 


\section{LARAMIE PEAK HMP \\ WILDLIFE SPECIES LIST}

vovars

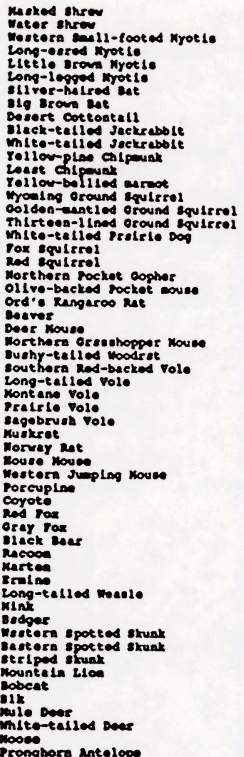

Pronglora Antelopo

nea

Relnbou frovt

Drow Trout

orook Frout

Creek chel

Longnose sucker

mite sueker

notreram

Tlger salamandor worthere tooperd 7 rea Boreal chorve Prog

norrute

Worthor secobruah Lleard

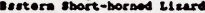
vill sacke

Wander lan carter salke

Prairie tateleanate

\author{
corex eterve \\ corex pleserie \\ prots elidederu \\ ryot de ovecte \\ ryoele lecirves \\ rroele wiane \\ Leslearcterlo nocelvegeas \\ Eptesiove teceres

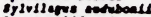 \\ Lope cellperniare \\ Lope toverearis

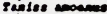 \\ giales alcies \\ Marmoce Lleviventede \\ spormoplice eleguae \\ iparnophes istersile

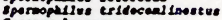 \\ cyacalo laverus \\ celurve aigar

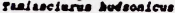 \\ rhowate talpotios \\ progactses Pascietes \\ - Lpodany arill \\ Cartor cenedeasis \\ perar eces andevietes \\ Onjcheng Iencogester \\ Iootona clearea \\ clechrlanem gepoed \\ microtve langlesules \\ ilcrotus notanas \\ ulerotes olvrogestar \\ Lomiceve curtater \\ andetre isechige \\ tet tue sarmelces \\ Tus weceles \\ sepue priscon \\ trothisea derate \\ Cende Ietran \\ Vulpos wiones \\ - rocjaa elevrourgat eue \\ Oreve aborleave. \\ Procrea Ioter \\ wart es anorlcan \\ Iustela emined \\ zuetele frover \\ rustele riean \\ saridee tarve \\ Ipllogale erectile \\ ipllogale pucartes \\ rophitie sopute \\ Telle coescier \\ Polle rafu \\ Cerves canchare \\ docolles nenioese \\ docollev interese \\ Neve clea \\ Dat llocapre aborteand
}

Oncerlyracles poles

galeo ervec

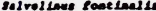

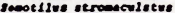

cetostarte cheotome

catortane conerval

Aabyetane tgrtat

rene piplane

resudecte erleorlece

sceloporve erectoves

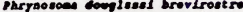

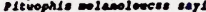

rhanopile lopase vegrase

croteles otritis virite 
0

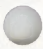

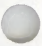


Tarter witere

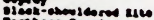

Erther Earte.

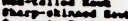

Gerien: an

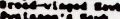

misce 's Ex

Cile enis

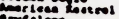

orialeat

piririo poleo

crey parise

colne

if arocked nesect

wite

viniale this

cee.

vertes oos

toliar

chesis Cram

viect-toliten olemer

Loceer Golba-piever

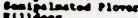

xilize

Goeted sandplper

ructied Cosule

Oomon calo

Pranksta' Gas

bech sow

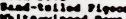

mite $\sim$ Lin

- ivel $\rightarrow$ lise curbo

care on

beters eccuclas

preet bormed ow

sear of

Lan-ared on

Giort-ared os

cortive in ow on

comon If rive bets

Conos roonds

Clewer ivire

cise-throuted sule

Cililope tho ingir

ores-calied inglintin

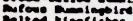

vile ninfioter

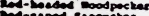

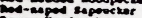

How toodpectias

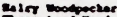

Inre-teed bodpocter

Corvere nicher

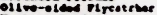

evere bod-rine

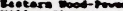

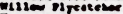

wotere nivectios

Lanet Ir reatetoe

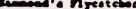

voly Pryectine

crey 1 reatet

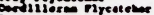

Excere renot.

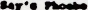

Eoters rinoted

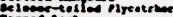

coring tapt

Tieletires

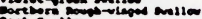

cent in 120

ciste naile

cars coive

erel ser.

ำ $10 \%$

Itage Jar

Clark'- Dercerte

iect $\rightarrow 13804$ wote

coriece cro

- bect-eaped calchene

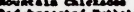

nite-bresered nuthet

nite-bronet

ras creepe

erest cros

cance ires

enlek. How

Bowes ine

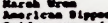

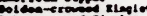

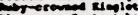

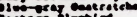

Evetere iteoln

cotere ievirs

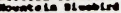

rmenen." collters

Tear cociversed care

Pante initecte.

glaves coervitas

Clrve orewes

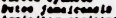

colotier etelote.

seloles eriert

Grtes Letrotern

otes wo have

bete itcres

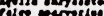

Dese resteves

Pelo malcuen

pordis eretis

incerile elaber

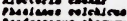

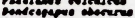

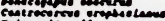

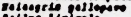

collod tialeole

porace curotin

riles inerlicas.

lade plotyrtyect

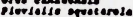

pivialis pritalo

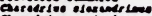

Caredrito ovelatente

acredel to netforve

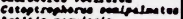

ictitio enteris

Provales checpes

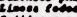

cilisere gollisere

carve 2 Lince

colven inte

coloned fackise

sevide islat lov

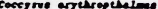

rite ilve

tee ead

oub v Lro Latawe

preter acentives

ile ote

Lie liseres

Aproliwe extime

cordolloe wear

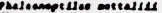

Custere colmies

corveset of entats

redilato cellite

silecharve pletrource

colecpleres mites

corplo aserea

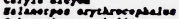

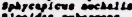

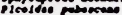

plovidar viliena

plovidas erldoetylos

colevtes seretes

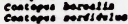

custewe - Lren

misant eralu

aldoen ilficule

ol lover alal

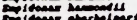

Divarar abarblo

Dilevar ortedell

serernes avolo

esporialo eap

orreces entionts

zraees egraen

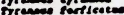

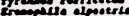

roet rever Noler

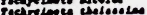

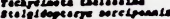

ceperse reveris

orves epreteenes

Limen eprateos

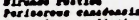

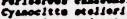

graocites etellers

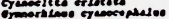

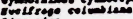

ica 1 e

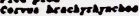

corme seres

perve exzlecpllies

parve ramis

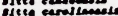

stce carvilach

sites sraces

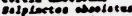

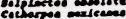

cotwages micaces

rreptedreed colst

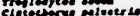

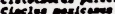

sopiles atres

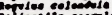

- liaplite cearvies

- rasia clatio

sibile corlcan

siejia curruction.

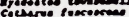

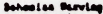

cocer town.

vretaen nesilo

viliter rires

folienturested now

ierivis vires

milestris vire

corered viese

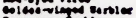

Pesmece tertie

or onpereroned varti ex

Deotilie Earties

virviale: Ente

Dorivers parvis

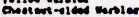

Marelile Eartice

Dicen-tivested varbles

8ollowned earbie

ock-thrested erer torbse

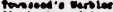

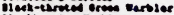

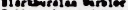

Poilem-iarested terbie

in verbice

in

19oknil vite

siect-an-jite tarbles

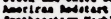

protbocter terble

corbetiay vertice

oreabir

corthice Etertanet

colecky tartic

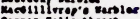

coosed Tolloger

ilioes tartic

caved vartice

Tollowbreatiol chet

Eppet lo rackes

oncer ravere

waters reaceres

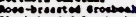

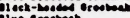

liwe croovels

Licell bet in

Tedipo mat io

irkel eces

crean-telliod rovien

tw fone-eised rowe.

noetcas free sparto

Oippin sperrev

ciop-coliones oparre.

ormer' enverne

nall operte

Vesper cherre

Lark iperm

sage iparry

savenat oparrest

eresaboiner mere

res eperre

itacel: therre

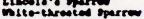

witemerom inarte

curcte- opereve

ark-ora

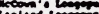

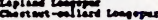

inco

lobelis

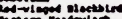

rem inclool

Poliow valed bisetion

evety ilection

Orwer:" incitis

comon erectis

trom-noded contr

oreherd erielo

cortiore oriele

Dow Plive

Diec iroetion.

loves in

iod Gropelis

bite $\rightarrow$ ing crosedss 
0

0

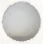




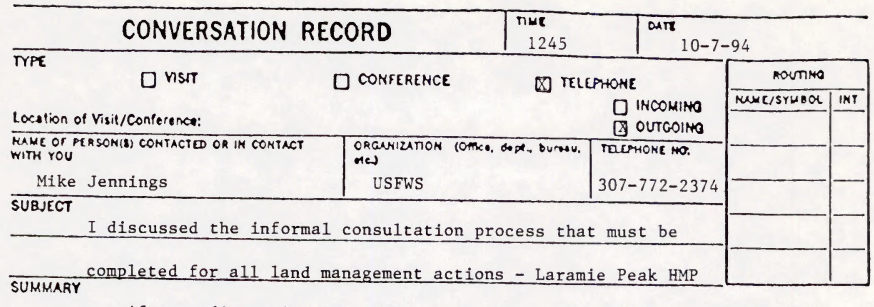

After a discussion with Mike concerning the informal consultation

process for $T / E$ species for land management documents, he stated that he

prefers to complete consultations at the EA level. It is really at this

level that pertinent information can be truely assessed, especially if some

of these planned actions will not occur for years down the road. Completing

an assessment now does not really analyze the true conditions and or events

that will occur in the near future and later on. An EA for a programatic

HMP does not address the "true" T/E conditions, especially if planned actions

do not occur years down the road. He would rather do a more thourough

analysis at each EA level for the 15 projects involved in the HMP --it's

- more effective and accurate that way. I explained that we hope to use an

Administrative Determination Document tiered off of the GDRA RMP, which he

feels makes more sense, but if we have to use an EA, then he will have to

View the HMP and complete formal consultation. He'd rather do this at the

individual EA level ( 15 total)

ACTION REQUIRED

Simply see if an $A D$ document passes and is signed by the Area Maanger, then

contact the USFWS on each EA for informal/formal consultation

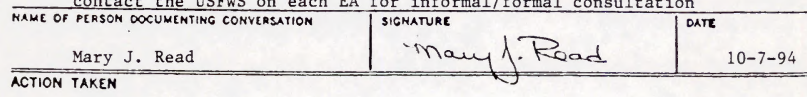

Consult USFWS for all EAs in progress in HMP

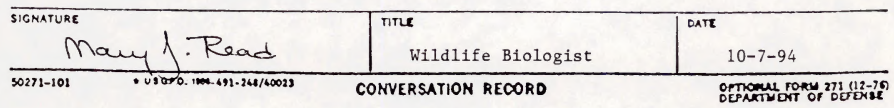


0

0

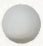


SPECIAL ETATUS EPECIES

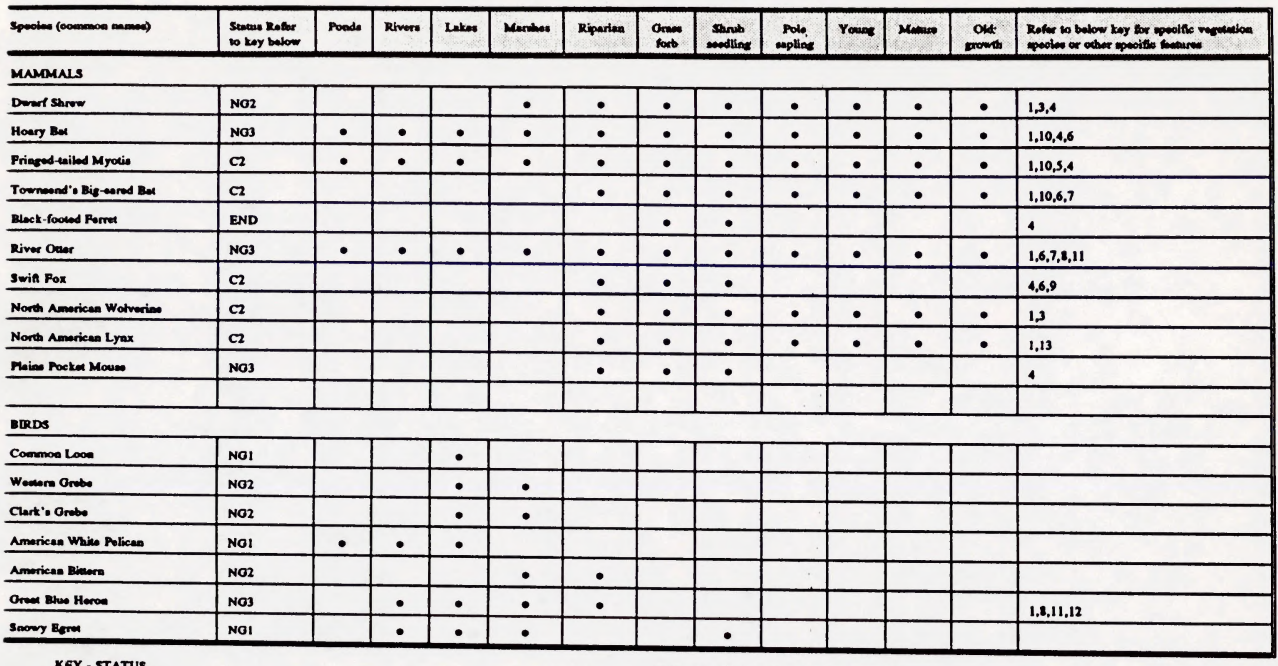

KEY - sTaTUS

lieved at Endengered

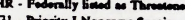

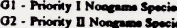

O2 - Prioriky II Nonemen Spocies

a3 - Priority III Noneseno Specien

- Candideco Spacien for Foderal lixting (WOFD)

1-USFws Netion of Roview, Calorery

2 - USFW's Notion of Roview, Calogory 2

3. Usfwrs Notion of Roview, Colagery 3

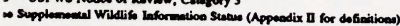

\section{KEY - SPECIPIC SPECIES OR FEATURF}

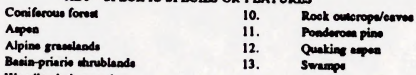

Baviappriario thrublead

Swamp:

Woodland-ehoparme

Mounteis-foochills ahrublends

Pino-juniper

Lodsepolo pine

Moureniar-foochille grenelands
LARAMIE PEAK HMP SPECIAL STATUS SPECIES 
0

0

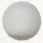


SPECINI ETATUE EPECIES

\begin{tabular}{|c|c|c|c|c|c|c|c|c|c|c|c|c|c|}
\hline 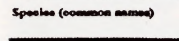 & $\begin{array}{l}\text { sectus Rofier } \\
\text { to key below }\end{array}$ & Ponde & Rivere & Lakes: & Menbes & Riparien & Oraes & $\begin{array}{l}\text { Shrub } \\
\text { noedline }\end{array}$ & Polv & Youns & Maver & Old: & 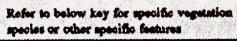 \\
\hline \multicolumn{14}{|l|}{ BRRDS Continued } \\
\hline Mleok-orowred Nighe Heron & NoI & & $\bullet$ & $\bullet$ & $\bullet$ & $\bullet$ & & & & & & & 12 \\
\hline Whice-foced bis & C,NOI & & & $\bullet$ & $\bullet$ & & & & & & & & \\
\hline Trumpeler $3 w a 0$ & C.NGI & $\bullet$ & $\bullet$ & $\bullet$ & $\bullet$ & & & & & & & & \\
\hline Bald Eiaglo & END & & $\bullet$ & $\bullet$ & & $\bullet$ & & & & & & & $1,8,11,12$ \\
\hline Northern Oochawk & $\mathrm{C2}$ & & & & & $\bullet$ & & $\bullet$ & $\bullet$ & $\bullet$ & $\bullet$ & $\bullet$ & $2,8,11,12$ \\
\hline Forruginows Hawk & $C 2$ & & & & & & $\bullet$ & $\bullet$ & & & & & $4,9,10,11$ \\
\hline Mortin & No2 & & & & & $\bullet$ & $\bullet$ & $\bullet$ & $\bullet$ & $\bullet$ & $\bullet$ & $\bullet$ & $1,8,11,12$ \\
\hline Porngrin Falcon & END & & & $\bullet$ & $\bullet$ & $\bullet$ & $\bullet$ & - & $\bullet$ & $\bullet$ & $\bullet$ & $\bullet$ & $1,8,10,11$ \\
\hline Plping Plover & THR & $\bullet$ & $\bullet$ & $\bullet$ & $\bullet$ & & & & & & & & \\
\hline Mounenia Hover & Cl & & & & & & $\bullet$ & & & & & & 4 \\
\hline Uplend Sendpiper & No1 & & & & & & $\bullet$ & & & & & & 4,9 \\
\hline Lonebilled Curlow & $\mathrm{C3}$ & & & & & & $\bullet$ & & & & & & 9 \\
\hline Cespien Tern & NoI & & $\bullet$ & - & $\bullet$ & & & & & & & & \\
\hline Foneder's Tore & NGI & & $\bullet$ & - & $\bullet$ & & & & & & & & \\
\hline Bleck Torn & $C 2$ & & $\bullet$ & $\bullet$ & - & & & & & & & & \\
\hline Yallow billed Cuctioo & No2 & & & & & $\bullet$ & & $\bullet$ & $\bullet$ & - & $\bullet$ & & 1,12 \\
\hline Durrowine Ow & $\mathrm{NO2}$ & & & & & & $\bullet$ & & & & & & 4 \\
\hline Lowio' Woodpecker & No3 & & & & & & & - & & $\bullet$ & $\bullet$ & $\bullet$ & $1,2,7,11$ \\
\hline Bleck-becked Woodpecker & NG2 & & & & & & & & & $\bullet$ & $\bullet$ & $\bullet$ & 1,8 \\
\hline 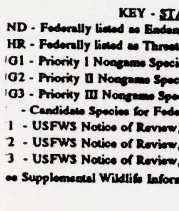 & $\begin{array}{l}\text { (WOFD) } \\
\text { o } 1 \\
\text { r } 2 \\
3 \\
3 \\
\text { yeus (Appeadix }\end{array}$ & or defi & & $\begin{array}{l}1 . \\
2 . \\
3 . \\
4 . \\
5 . \\
6 . \\
7 . \\
8 .\end{array}$ & $\begin{array}{l}\text { Coni } \\
\text { Appe } \\
\text { Npis } \\
\text { Bexis } \\
\text { Woo } \\
\text { Mour } \\
\text { Pine- } \\
\text { Lods } \\
\text { Mour }\end{array}$ & 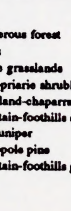 & ande & KEY - & $\begin{array}{l}\text { PECIFIC S } \\
10 . \\
11 . \\
12 . \\
13 .\end{array}$ & $\begin{array}{l}\text { PECIBS OA } \\
\text { Rock ouec } \\
\text { Poadoroen } \\
\text { Quakin } \\
\text { Swrampe }\end{array}$ & $\begin{array}{l}\text { PEATUR } \\
\text { ropa/cerves } \\
\text { pino } \\
\text { peo }\end{array}$ & $\begin{array}{l}\text { ARAR } \\
\text { CIAL }\end{array}$ & $\begin{array}{l}\text { IE PEAK HMP } \\
\text { TATUS SPECIES }\end{array}$ \\
\hline
\end{tabular}




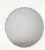

0

0 
orscial aratua erecies

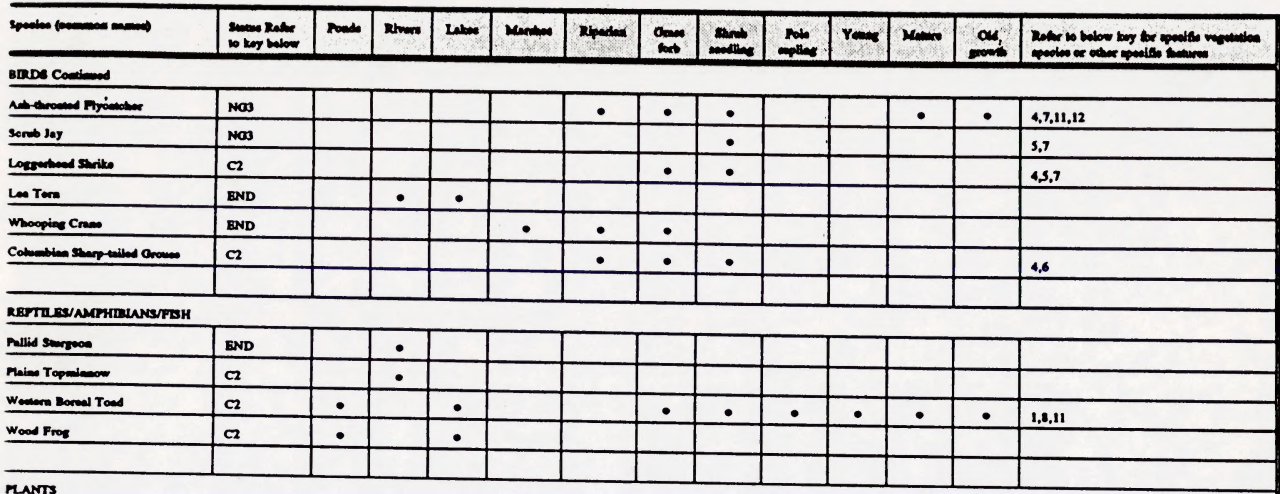

HaNTS

Cypripation trecioulan

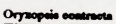

Sptecromonde dimplex

\begin{tabular}{|l|l|}
\hline$c 2$ \\
\hline$C 2$ \\
\hline$C 2$ \\
\hline
\end{tabular}

$+$

\section{KeY - sTaTus}

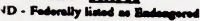

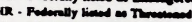

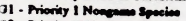

32 - Mioriny II Nongenes specin

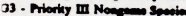

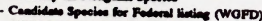

1. Uspiws Notion of Roviow, Caverory 1

2. USPW' Notien of Romiow, Cenegory 2

1. USPW's Notion of Boviow, Cmorory 3

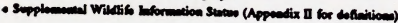

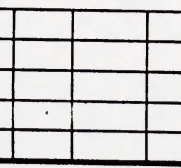

\begin{tabular}{l|l|}
\hline \\
\hline
\end{tabular}

\begin{tabular}{|l}
\hline \\
$\bullet$ \\
\hline
\end{tabular}

Coniberen foren

Ampen

Apiem gromenodo

Baclepprierib thriblead

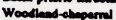

Moumele-foochille itrubleade

Fiofueiper

Loderpolo pien

Movialo-foctillo gromiands
LARAMIE PEAK HMP SPECIAL STATUS SPECIES 
0

0

0 


\section{APPENDIX IV}

Crucial Winter Range for Big Game

Wildlife Species and WGFD Hunt Areas 


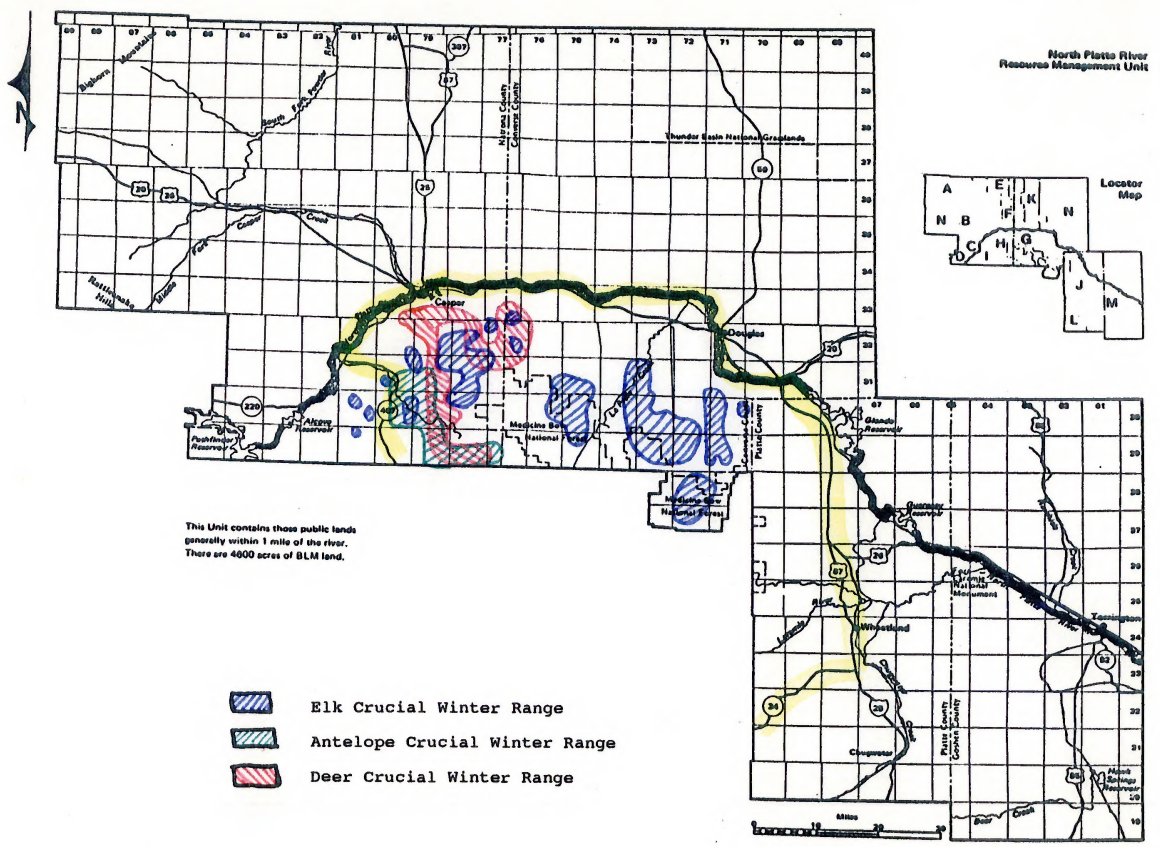



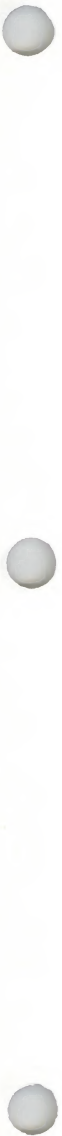
0

0

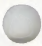




\section{WYOMING BIGH' $V$ SHEEP HUNT AREAS}

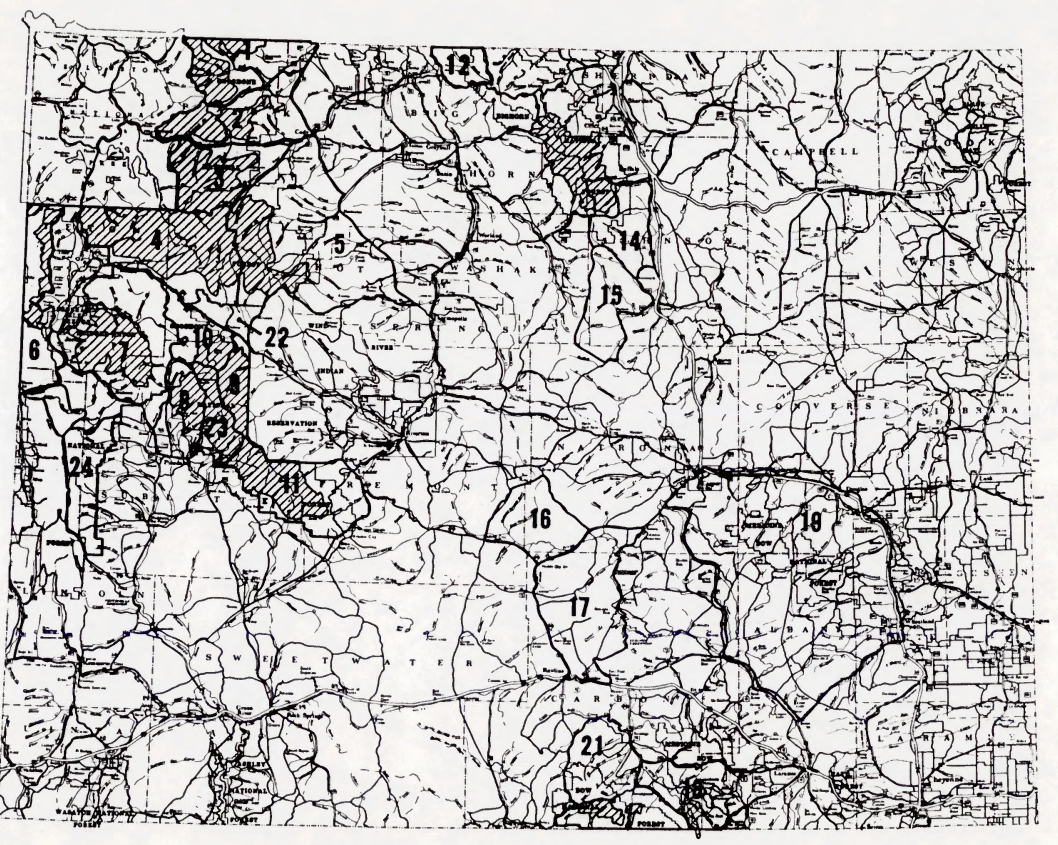

Note: WIIIIII Wilderness area, nonresidents must have guides. 
0

0

0 


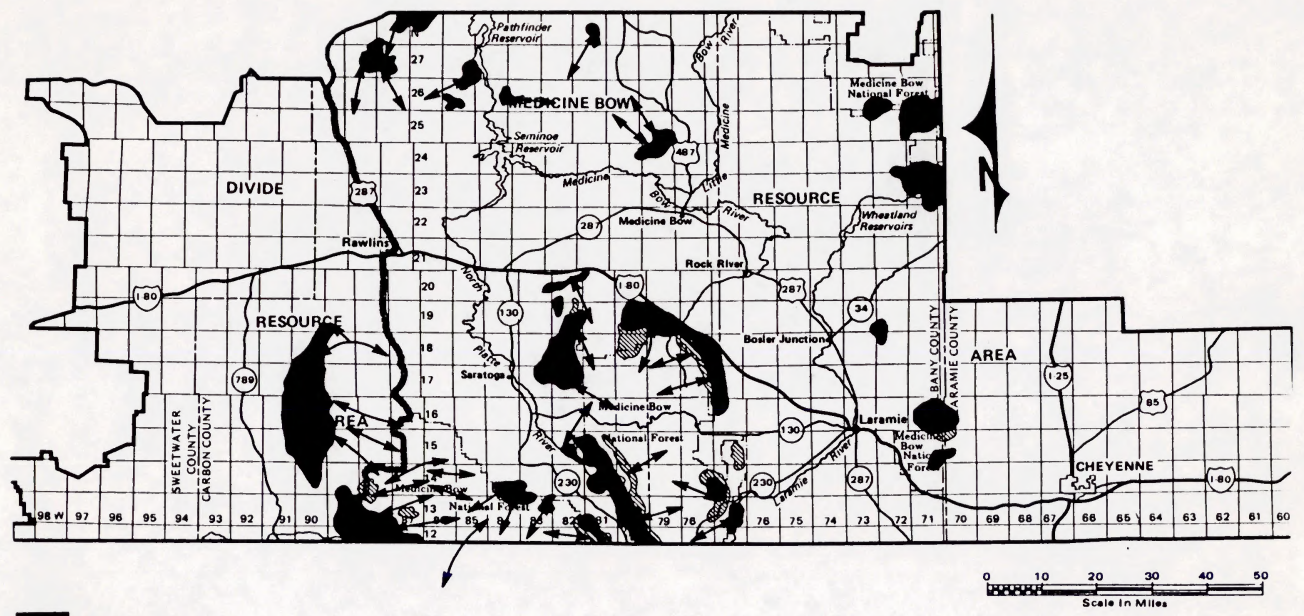

Crucial Winter Range

Calving Areas

$\longleftrightarrow$ Migration Routes 
0

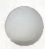

0 


\section{WYOMING K HUNT AREAS}

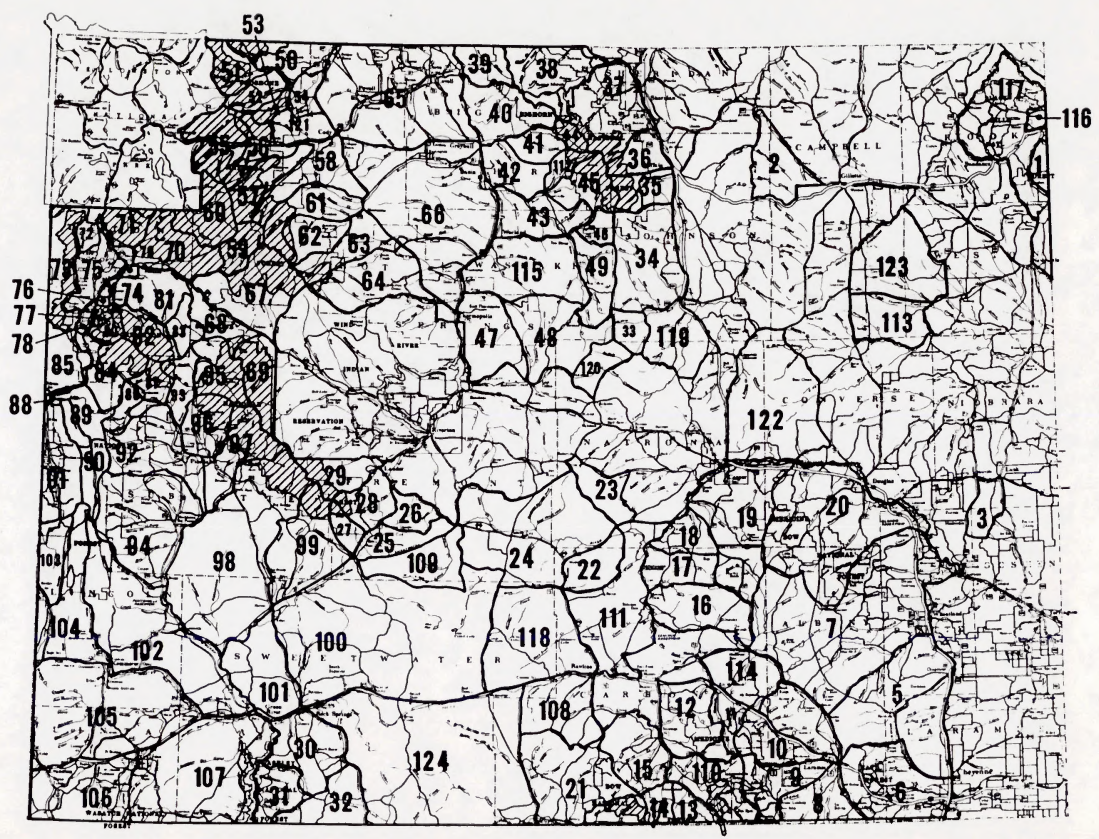

Note: VIIIIII Wilderness area, nonresidents must have guides. 
0

0

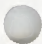




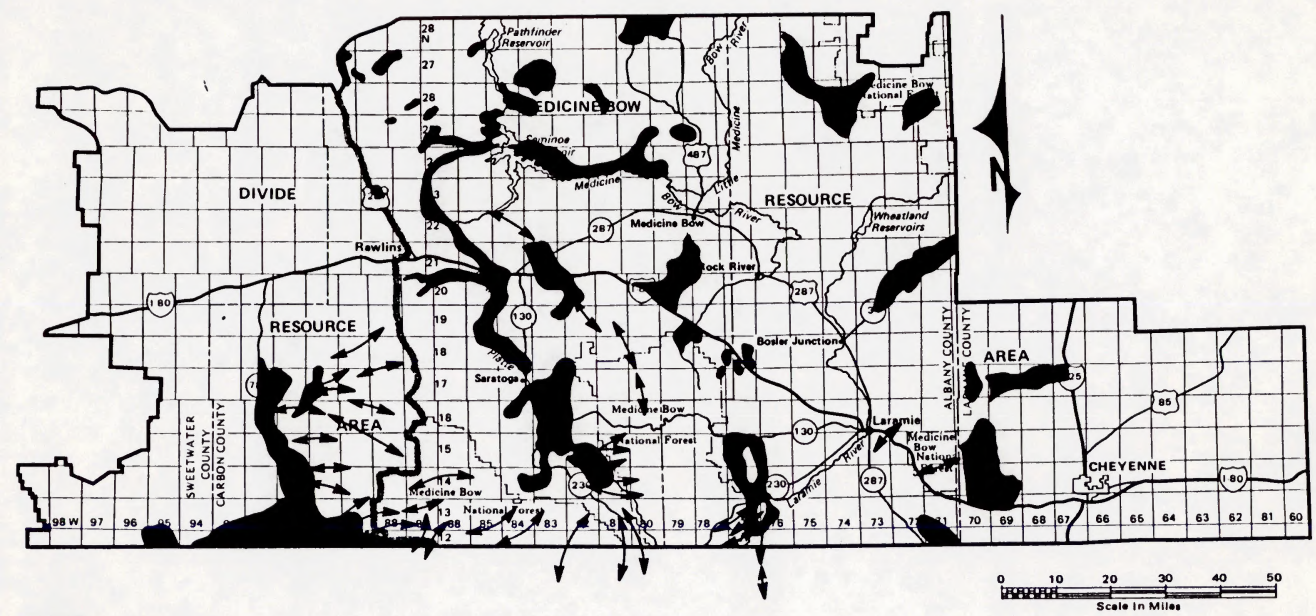

Crucial Winter Range

Migration Routes

MULE DEER CRUCIAL WINTER RANGE AND MIGRATION ROUTES 


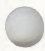

0

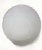




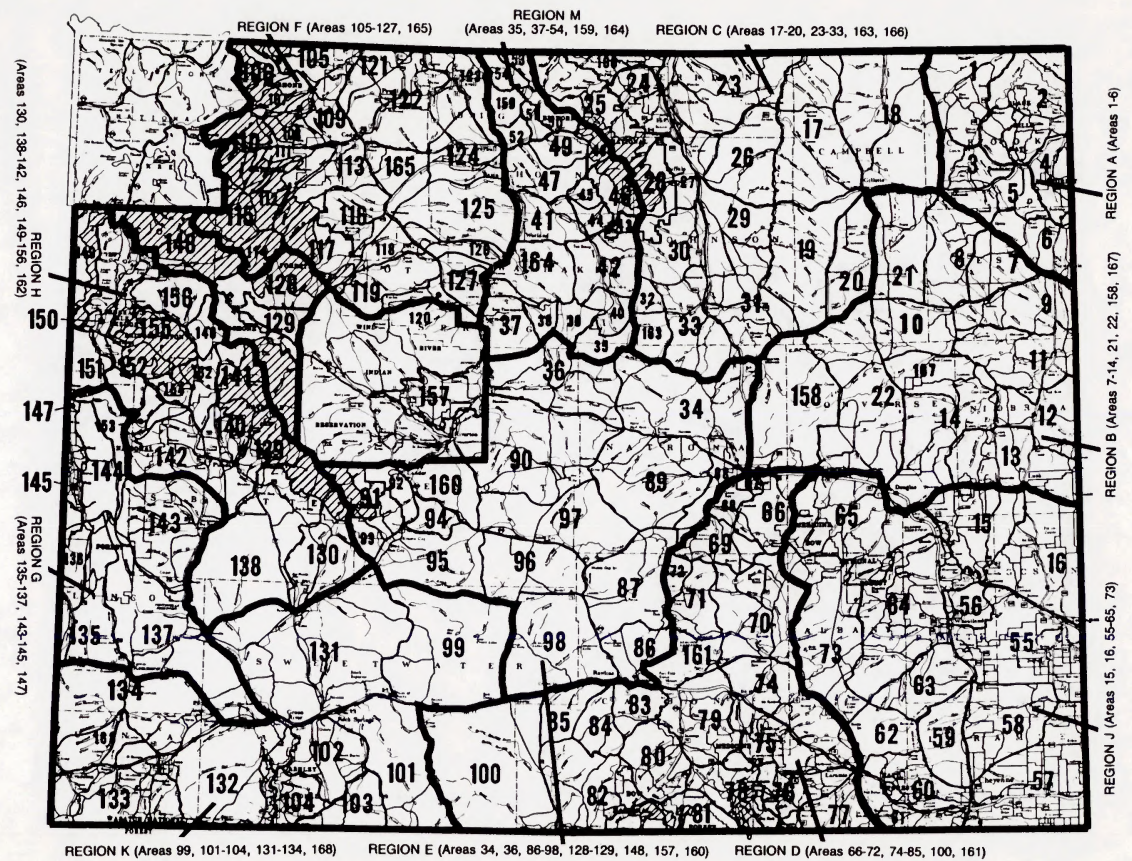

Note: VIIIIIII Wilderness area, nonresidents must have guides. 
0

0

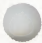




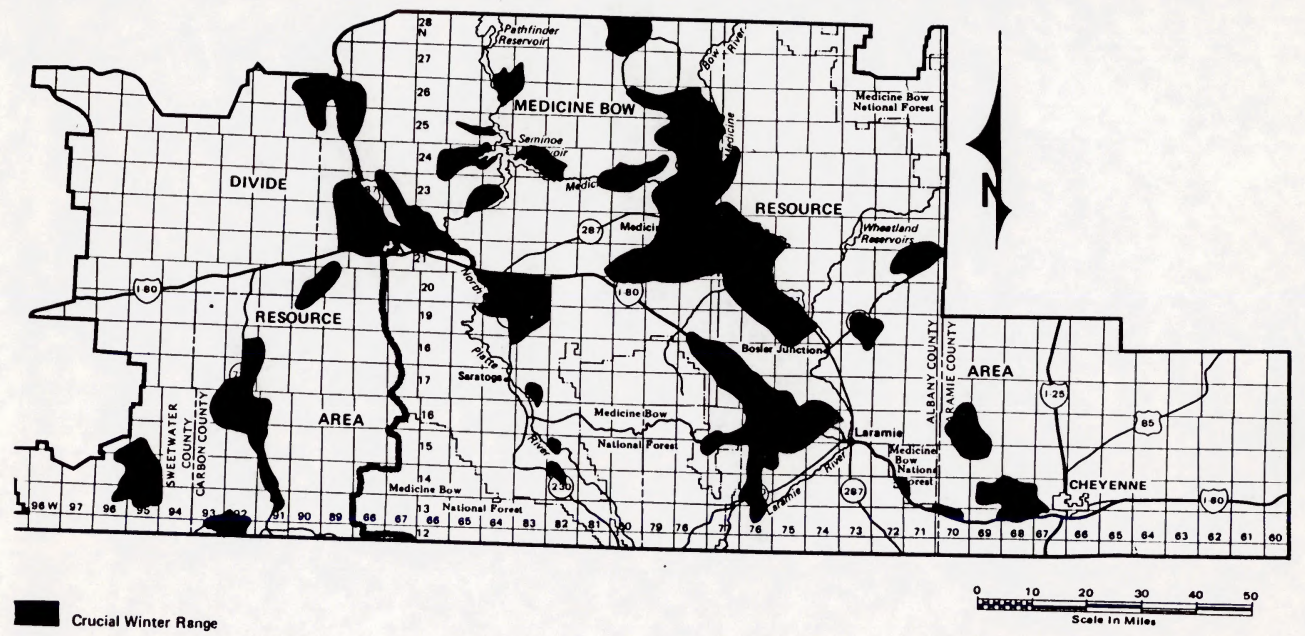


0

0

0 


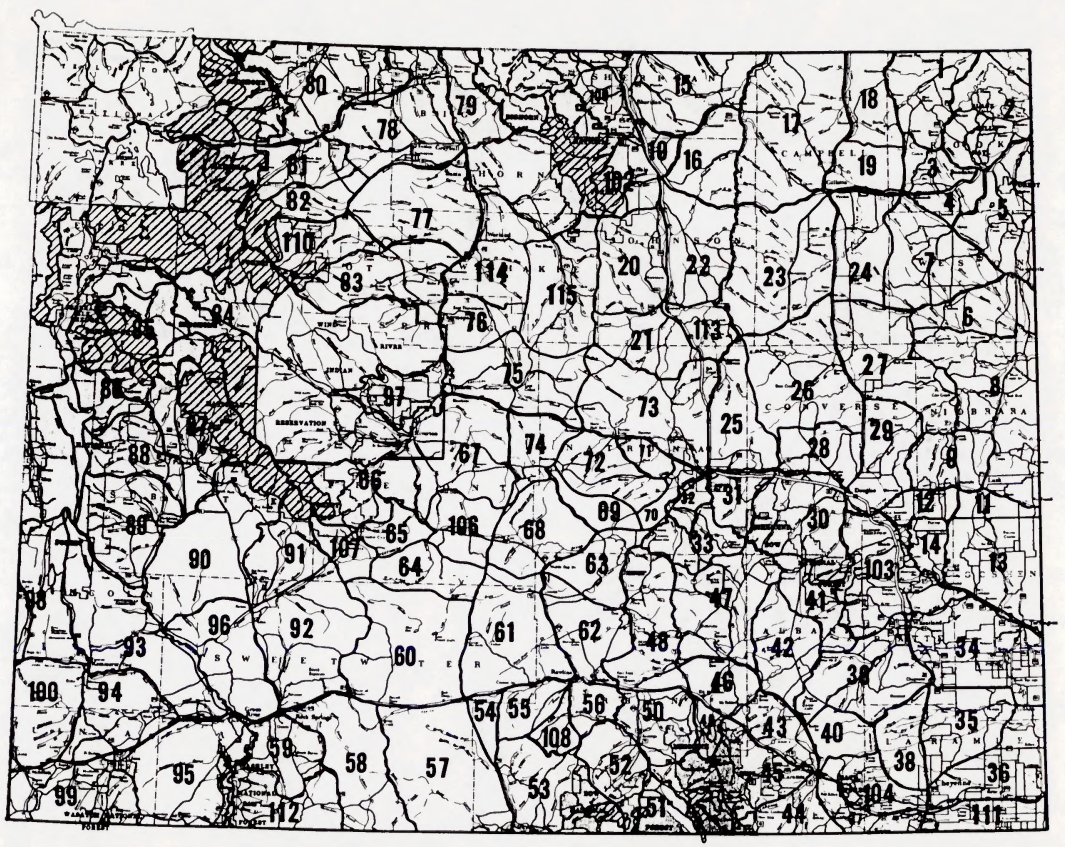

Note: VIIIIIII Wilderness area, nonresidents must have guides. 
0

0

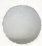




\section{APPENDIX V}

\section{Breeding/Nesting Habitat for Sage Grouse}

Crucial Winter Habitat for Turkeys 
0

0

0 


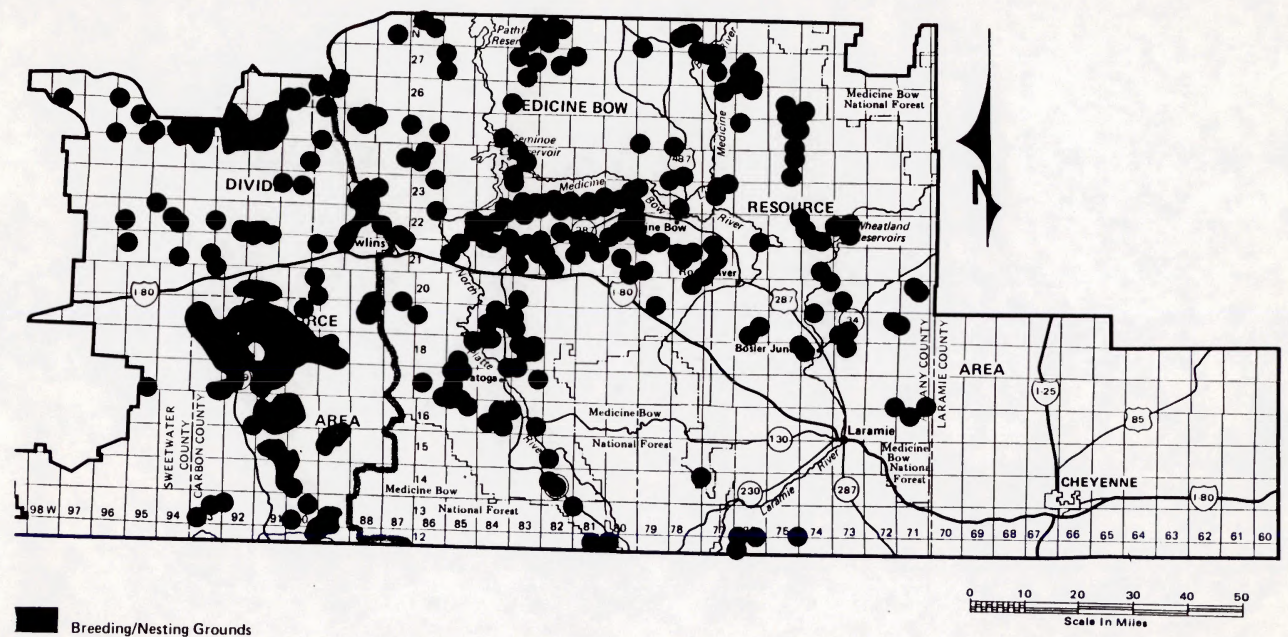




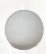

0

0 


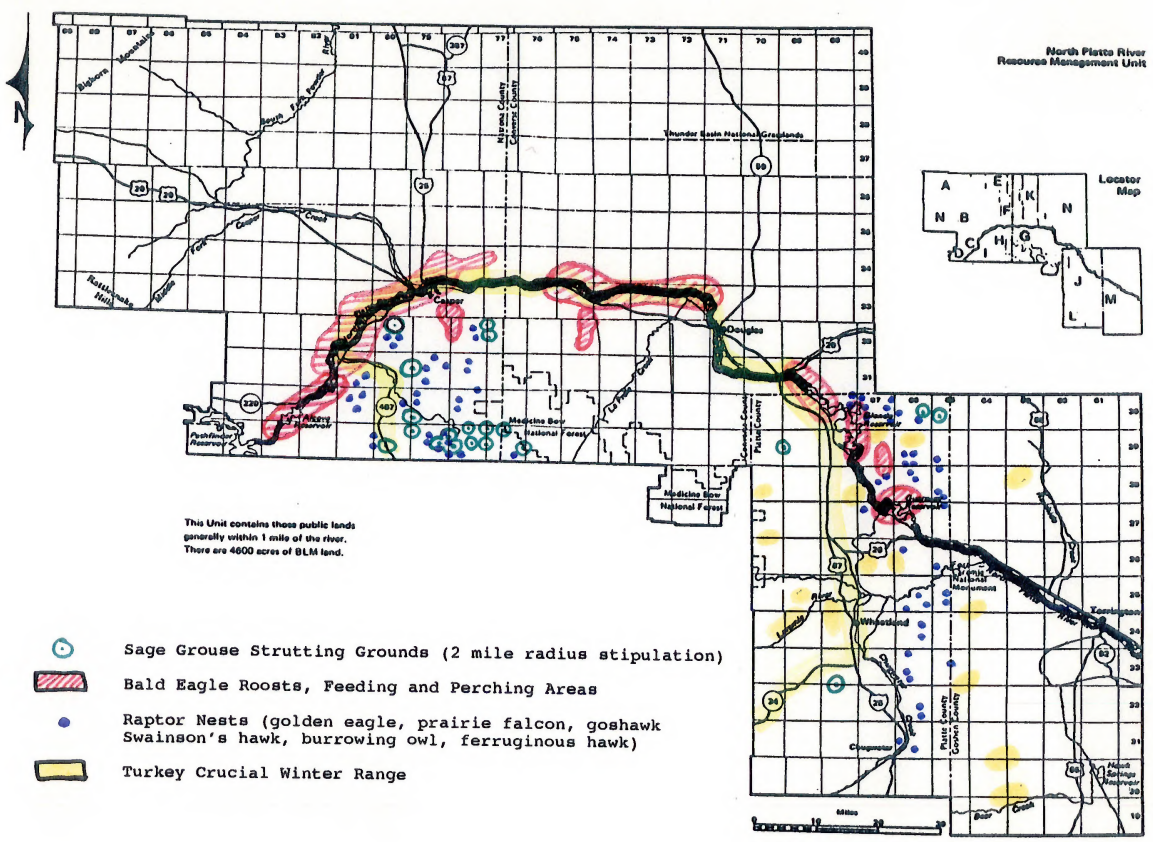



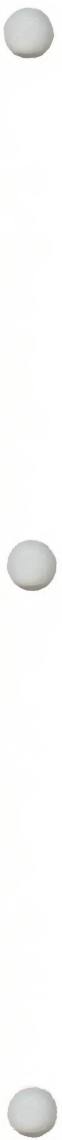


\section{APPENDIX VI}

WGFD Hunt Areas - Major Predators 


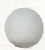

0

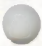




\section{WYOMING MOUN' IN LION HUNT AREAS}

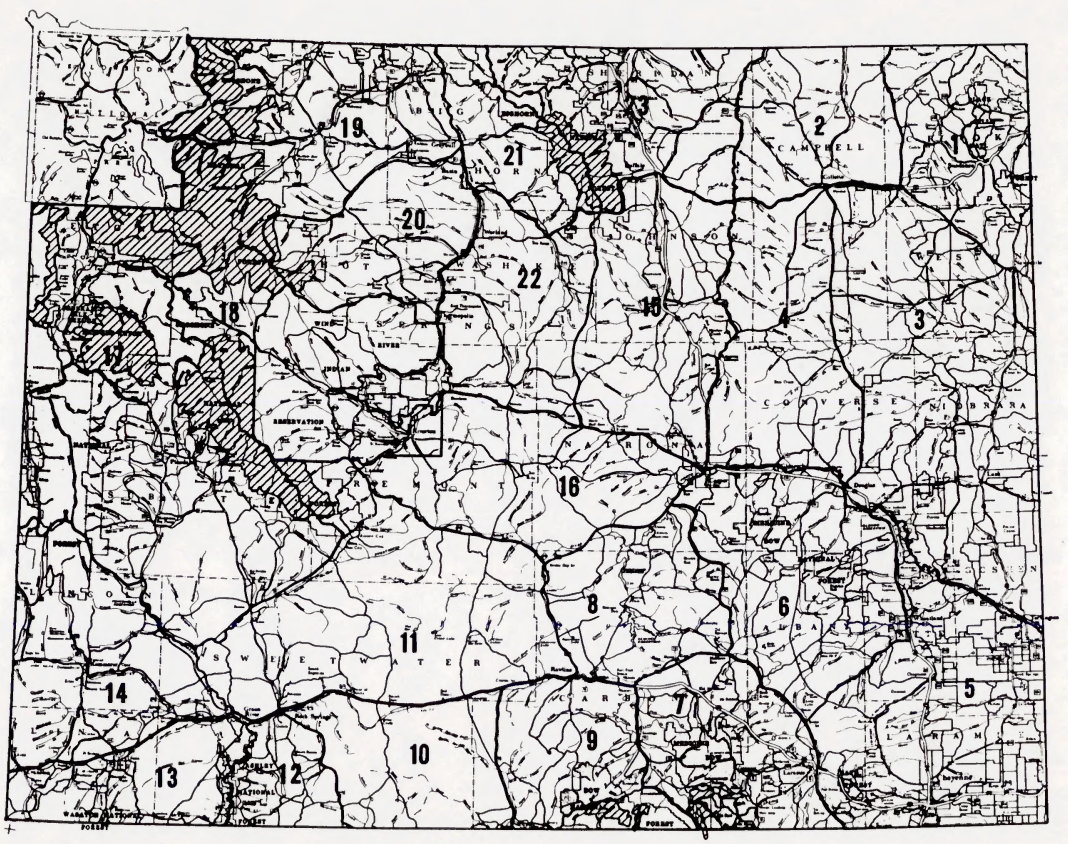

Note: VIIIIIII Wilderness area, nonresidents must have guldes. 
0

0

0 


\section{WYOMING BLA BEAR HUNT AREAS}

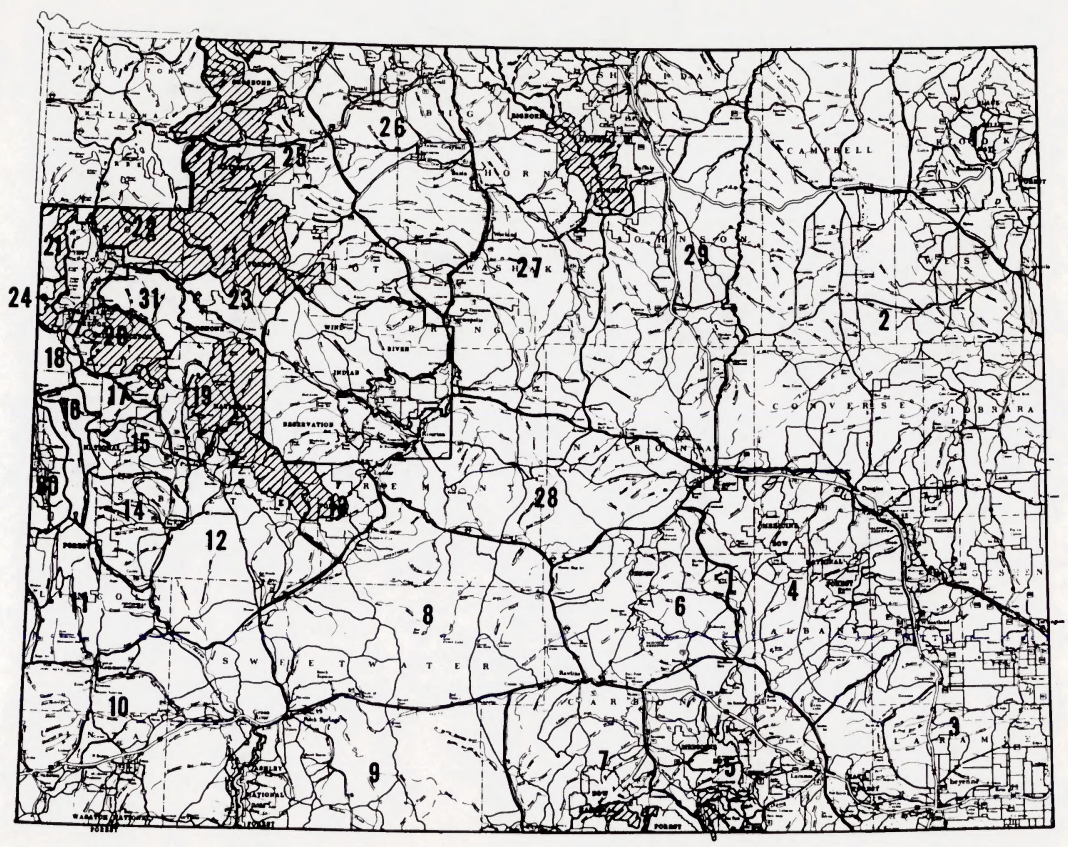

Note: WIIIIII Wilderness area, nonresidents must have guides. 
0

0

0 


\section{APPENDIX VII}

General Framework of Guidance for the Bureau's (BLM) Fish and Wildlife Program 
0

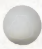

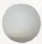




\section{NATIONAL POLICIES}

There are situations where the directives contained in the various laws, regulations, Departmental policies, and Executive Orders are subject to interpretation. In such cases, Bureau policies guide managers in planning and decisionmaking. The following provide a general framework of guidance for the Bureau's fish and wildlife program:

1. Recognize State management of resident species and that a State-Federal partnership is essential for species-habitat management programs. In working with the States, the BLM will continue to use its authority under the Sikes Act as one of the primary means for achieving effective coordination.

2 Forge strong and effective communications and coordination between the wildlife program and other Bureau programs, encouraging interdisciplinary teamwork in the development of resource management options that meet fish and wildlife objectives.

Initiate active cooperation with State, local, and other Federal agencies in all fac- ets of the wildlife program. These agencies are encouraged to maximize use of available resources by providing funds, equipment or exchanging information and skills needed for fish and wildlife management.

4. Create opportunities for broad public involvement that will foster awareness, support, assistance, and participation in cooperative programs that enhance fish and wildlife habitat.

5. Actively encourage Cooperative Management Agreements with wildlife management agencies and organizations, other conservation interests, and public service groups.

6. Focus inventory, monitoring, and research efforts in areas of high wildlife values, concerns, opportunities, and where public interest or controversy exists.

7. Develop recommendations for wildlife habitat management based on analysis of ecological conditions, legal mandates, Federal goals for migratory species and federally listed threatened or endangered species, State goals for resident wildlife populations, social and economic values, and concerns of the public.
8. Maximize fish and wildlife resource opportunities through program initiatives, such as HMP's, Cooperative Management Agreements, and constructive interaction with other resource uses and activities.

9. Conduct investment analyses to ensure that all habitat improvement plans constitute the most cost-effective means of achieving stated management objectives for fish and wildlife habitat.

10. Develop incentives to encourage benefitting users, including local governments, interest groups, and individuals, to invest in fish and wildlife habitat management and enhancement.

11. Strengthen and improve the professional, technical, interdisciplinary, and managerial skills of Bureau fish and wildlife personnel to enhance their performance and increase job satisfaction.

12. Acquire land for fish and wildlife purposes only when other means of achieving program goals and objectives are not appropriate, available, or effective, giving full consideration to exchanges or other alternatives. 
0

0

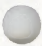


13. The protection, enhancement, and recovery of $\mathrm{T} / \mathrm{E}$ species will receive priority consideration in all Bureau activities.

14. Maintain and rehabilitate existing habitat management facilities to provide maximum public benefit and to protect prior investments.

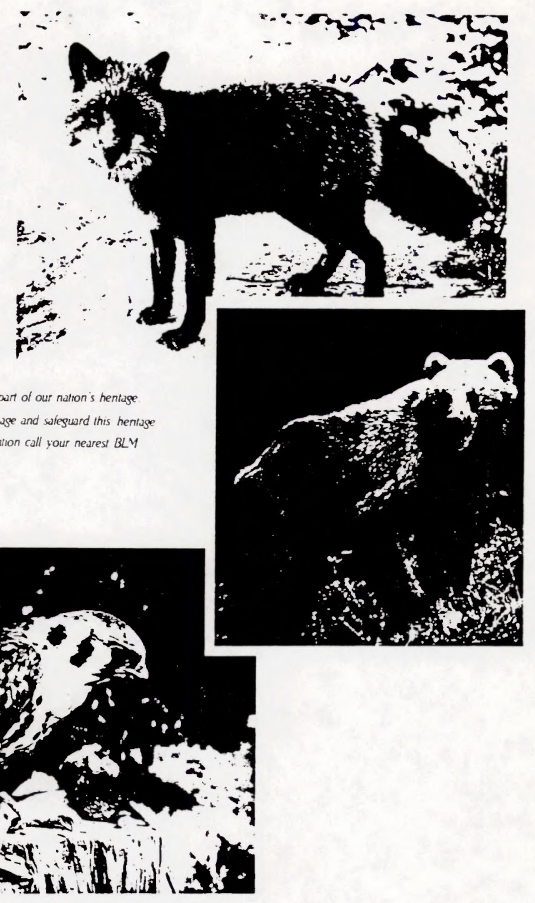

Fish and uildile is an amportant part of our nation's hentage lou can be a part of heipung manuge and saleguard this hentuge for future generations for information call your nearesi BLM otfice

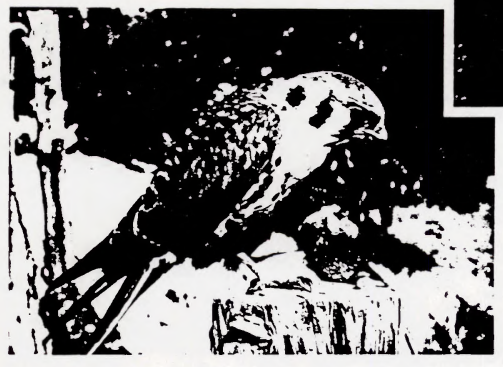




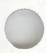

0

0 


\section{APPENDIX VIII}

BLM Standard Mitigation Guidelines for

Surface-Disturbing Activities 
0

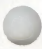

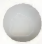


lines have been written in a format that will aliow for (1) their direct use as stipulations, and (2) the addition of specific or specialized mitigation following the submission of a detailed pian of development or other project proposal, and an environmental analysis.

Those resource activities or programs currently without a standardized set of permit or operation stipulations can use the mitigation guldelines as stipulations or as conditions of approval, or as a baseline for developing specific stipulations for a given activity or program.

Because use of the mitigation guidelines was integrated into the RMP/EIS process and will be integrated into the site-specific environmental analysis process, the application of stipulations or mitigation requirements derived through the guidelines will provide more consistency with planning decisions and plan implementation than has occurred in the past. Application of the standard mitigation guidelines to all surface and other human presence disturbance activities concerning BLM-administered public lands and resources will provide more uniformity in mitigation than has occurred in the past.

\section{STANDARD MITIGATION GUIDELINES}

\section{Surface Disturbance Mitigation Guldeline}

Surface disturbance will be prohibited in any of the following areas or conditions. Exception, waiver, or modification of this limitation may be approved in writing, including documented supporting analysis, by the Authorized Otficer.

a. Siopes in excess of $\mathbf{2 5}$ percent.

b. Within important scenic areas (Class I and II Visual Resource Management Areas).

c. Within $\mathbf{5 0 0}$ feet of surface water and/or riparian areas.

d. Within either one-quarter mile or the visual horizon (whichever is closer) of historic tralis.

e. Construction with frozen material or during periods when the soil material is saturated or when watershed damage is likely to occur.

\section{Juldance}

The intent of the SURFACE DISTURBANCE MITIQRTION GUIDELINE is to inform interested parties (potential lessees, permittees, or operators) that when one or more of the five (1a through 1e) conditions exist, surface-disturbing activities will be prohibited unless or until a permittee or his designated representative and the surface management agency (SMA) arrive at an acceptable plan for mitigation of anticipated impacts. This negotiation will occur prior to development.

Specific criteria (e.g., 500 feet from water) have been established based upon the best information available. However, such items as geographical areas and seasons must be delineated at the field
level.

Exception, waiver, or modification of requirements developed from this guideline must be based upon environmental analysis of proposals (e.g., activity plans, pians of development, plans of operation, applications for permit to drili) and, if necessary, must allow for other mitigation to be applied on a site-specific basis.

\section{Wildilfe Mitigation Guideline}

a. To protect important big game winter habitat activities or surface use will not be allowed from November 15 to April 30 within certain areas encompassed by the authorization. The same criteria apply to defined big game birthing areas from May 1 to June 30 .

Application of this limitation to operation and maintenance of a developed project must be based on environmental analysis of the operational or production aspects.

Exception, waiver, or modification of this limitation in any year may be approved in writing, including documented supporting analysis, by the Authorized Officer.

b. To protect important raptor and/or sage and sharp-tailed grouse nesting habitat, activities or surface use will not be allowed from February 1 to July 31 within certain areas encompassed by the authorization. The same criteria apply to defined raptor and game bird winter concentration areas from November 15 to April 30.

Application of this limitation to operation and malntenance of a developed project must be based on environmental analysls of the operational or production aspects.

Exception, waiver, or modification of this limitation in any year may be approved in writing. including documented supporting analysis, by the Authorized Officer.

c. No activities or surface use will be allowed on that portion of the authorization area identified 
0

0

0 
within (lega/ description) for the purpose of protecting (e.g., sage/sharp-tailed grouse breeding grounds, and/or other species/activities) habitat.

Exception, waiver, or modification of this limitation in any year may be approved in writing, including documented supporting analysis, by the Authorized Officer.

d. Portions of the authorized use area legally described as (legal description), are known or suspected to be essential habitat for (name) which is a threatened or endangered species. Prior to conducting any onsite activities, the lessee/permittee will be required to conduct inventories or studies in accordance with BLM and U.S. Fish and Wildlife Service guidelines to verify the presence or absence of this species. In the event that (name) occurrence is identified, the lessee/permittee will be required to modify operational plans to include the protection requirements of this species and its habitat (e.g., seasona/ use restrictions, occupancy limitations, facility design modifications).

\section{Guldance}

The WILDLIFE MITIGATION GUIDELINE is intended to provide two basic types of protection: seasonal restriction (2a and $2 b$ ) and prohibition of activities or surface use (2c). Item $2 d$ is specific to situations involving threatened or endangered species. Legal descriptions will ultimately be required and should be measurable and legally definable. There are no minimum subdivision requirements at this time. The area delineated can and should be defined as necessary, based upon current biological data, prior to the time of processing an application and issuing the use authorization. The legal description must eventually become a part of the condition for approval of the permit, plan of development, and/or other use authorization.

The seasonal restriction section identifies three example groups of species and delineates three similar time frame restrictions. The big game species including elk, moose, deer, antelope, and bighorn sheep, all require protection of crucial winter range between November 15 and April 30. Elk and bighorn sheep also require protection from disturbance from May 1 , to June 30 , when they typically occupy distinct calving and lambing areas. Raptors include eagles, accipiters, falcons (peregrine, prairie, and merlin), buteos (ferruginous and Swainson's hawks), osprey, and burrowing owls. The raptors and sage and sharp-tailed grouse require nesting protection between February 1 and July 31 . The same birds often require protection from disturbance from November 15 through April 30 while they occupy winter concentration areas.
Item 2c, the prohibition of activity or surface use, is Intended for protection of specific wild life habitat areas or values within the use area that cannot be protected by using seasonal restrictions. These areas or values must be factors that limit life-cycle activities (e.g., sage grouse strutting grounds, known threatened and endangered species habitat).

Exceptlon, waiver, or modification of requirements developed from this guldeline must be based upon environmental analysis of proposals (e.g., activity plans, plans of development, plans of operation, applications for permit to drill) and, if necessary, must allow for other mitigation to be applied on a site-specific basis.

\section{Cultural Resource Mitigation Guldeline}

When a proposed discretionary land use has potential for affecting the characteristics which qualify a cultural property for the National Register of Historic Places (National Register), mitigation will be considered. In accordance with Section 106 of the Historic Preservation Act, procedures specified in 36 CFR 800 will be used in consultation with the Wyoming State Historic Preservation Officer and the Advisory Council on Historic Preservation in arriving at determinations regarding the need and type of mitigation to be required.

\section{Guidance}

The preferred strategy for treating potential adverse effects on cultural properties is "avoidance." If avoidance involves project relocation, the new project area may also require cultural resource inventory. If avoidance is imprudent or unfeasible, appropriate mitigation may include excavation (data recovery), stabilization, monitoring, protection barriers and signs, or other physical and administrative measures.

Reports documenting results of cultural resource inventory, evaluation, and the establishment of mitigation alternatives (if necessary) shall be written according to standards contained in BLM Manuals, the cultural resource permit stipulations, and in other policy issued by the BLM. These reports must providesufficient information for Section 106 consultation. Reports shall be reviewed for adequacy by the appropriate BLM cultural resource specialist. If cultural properties on, or eligible for, the National Register are located within these areas of potential impact and cannot be avoided, the Authorized Offlcer shall begin the Section 106 consultation process in accordance with the procedures contained in $\mathbf{3 6}$ CFR 800. 
0

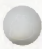

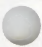


Mitlgation measures shail be implemented according to the mitigation plan approved by the BLM Authorized Officer. Such plans are usually prepared by the land use applicant according to BLM speclflcations. Mitigation plans will be reviewed as part of Section 106 consultatlon for Natlonal Register eligible or listed properties. The extent and nature of recommended mitigation shall be commensurate with the significance of the cultural resource Involved and the anticipated extent of damage. Reasonable costs for mitigation will be borne by the land use applicant. Mitigation must be cost effective and realistic. It must consider project requirements and limitations, Input from concerned parties, and be BLM approved or BLM formulated.

Mitigation of paleontological and natural history sites will be treated on a case-by-case basis. Factors such as site significance, economics, safety, and project urgency must be taken into account when making a decision to mitigate. Authority to protect (through mitigation) such values is provided for in FLPMA, Section 102(a)(8). When avoidance is not possible, appropriate mitigation may include excavation (data recovery), stabilization, monitoring, protection barriers and signs, or other physical and administrative protection measures.

\section{Special Resource Mitigation Guideline}

To protect (resource value), activities or surface use will not be allowed (i.e., within a specific distance of the resource value or between date to date) in (/egal description).

Application of this limitation to operation and maintenance of a developed project must be based on environmental analysis of the operational or production aspects.

Exception, waiver, or modification of this limitation in any year may be approved in writing, including documented supporting analysis, by the Authorized Officer.

Example Resource Categories (Select or identify category and specific resource value):

a. Recreation areas.

b. Special natural history or paleontological features.

c. Speclal management areas.

d. Sections of major rivers.

1. Prior existing rights-of-way.

f. Occupied dwellings.

g. Other (specify).

\section{Guldance}

The SPECIAL RESOURCE MITIGATION GUIDELINE is intended for use only in site-speciflc situations where one of the first three general mitigation guldelines will not adequately address the concern. The resource value, location, and specific restrictions must be clearly identified. A detalled plan addressing speciflc mitlgation and speclal restrictions will be required prior to disturbance or development and will become a condition for approval of the permit, plan of development, or other use authorization.

Exception, waiver, or modification of requirements developed from this guideline must be based upon environmental analysis of proposals (e.g., activity plans, plans of development, plans of operation, applications for permit to drill) and, if necessary, must allow for other mitigation to be applied on a site-specific basis.

\section{No Surface Occupancy Guideline}

No Surface Occupancy will be allowed on the following described lands (lega/ description) because of (resource va/ue).

Example Resource Categories (Se/ect or identity category and specific resource value):

a. Recreation Areas (e.g., campgrounds, historic trails, national monuments).

b. Major reservoirs/dams.

c. Special management area (e.g., areas of critical environmental concern, known threatened or endangered species habitat, wild and scencic rivers).

d. Other (specity).

\section{Guldance}

ThE NO SURFACE OCCUPANCY (NSO) MITIGATION GUIDELINE is intended for use only when other mitigation is determined insufficient to adequately protect the public interest and is the only alternative to "no development" or "no leasing." The legal description and resource value of concern must be Identified and be tied to an NSO land use planning decision.

Waiver of, or exception(s) to, the NSO requirement will be subject to the same test used to initially justify its Imposition. If, upon evaluation of a site speclfic proposal, it is found that less restrictive mitigation would adequately protect the publlc interest 
0

0

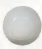


ur value of concern, then a waiver or exception to the NSO requirement is possible. The record must show that because conditions or uses have changed, less restrictive requirements will protect the public interest. An environmental analysis must be conducted and documented (e.g., environmental assessment, environmental impact statement, etc., as necessary) in order to provide the basis for a waiver or exception to an NSO planning decision. Modification of the NSO requlremet will pertain only to refinement or correction of the location(s) to which it applied. If the waiver, exception, or modification is found to be consistent with the intent of the planning decision, it may be granted. If found inconsistent with the intent of the planning decision, a plan amendment would be required before the waiver, exception, or modification could be granted.
When considering the "no development" or "no leasing" option, a rigorous test must be met and fully documented in the record. This test must be based upon stringent standards described in the land use planning document. Since rejection of all deveiopment rights is more severe than the most restrictive mitigation requirement, the record must show that consideration was given to development subject to reasonabie mitigation, including "no surface occupancy." The record must aiso show that other mitigation was determined to be insufficient to adequately protect the public Interest. a "no development" or "no leasing" decision should not be made solely because it appears that conventional methods of development would be unfeasible, espe cialiy where an NSO restriction may be acceptable to a potential permittee. In such cases, the potential permittee should have the opportunity to decide whether or not to go ahead with the proposal (or accept the use authorization), recognizing that an NSO restriction is involved. 


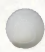

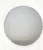

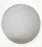




\section{WYOMING BUREAU OF LAND MANAGEMENT (BLM) STANDARD MITIGATION GUIDELINES FOR SURFACE-DISTURBING ACTIVITIES}

\section{INTRODUCTION}

The "Wyoming BLM Standard Oil and Gas Lease Stipulations" were developed in 1986. During their implementation, it was recognized that various land uses, other than those related to oil and gas exploration and development, should be subject to similar kinds of environmental protection requirements. Using the Wyoming BLM standard oil and gas iease stipulations as a basis, development of the "Wyoming BLM Standard Mitigation Measures for Surface-Disturbing Activities" began.

The term "guidelines" better describes the intent and use of these mitigation standards than the terms "stipulations" or "measures." These guidelines are primarily for the purpose of attaining statewide consistency in how requirements are determined for avoiding and mitigating environmental impacts and resource and land use conflicts. Consistency in this sense does not mean that identical requirements would be applied for all similar types of land use activities that may cause similar types of impacts. Nor does it mean that the requirements or guidelines for a single land use activity would be identical in all areas.

There are two ways the standard mitigation guidelines are used in the resource management plan/ environmental impact statement (RMP/EIS) process: (1) as part of the planning criteria in developing the RMP alternatives, and (2) in the analytical processes of both developing the alternatives and analyzing the impacts of the aiternatives. In the first case, an assumption is made that any one or more of the standard mitigations will be appropriately included as conditions of relevant actions being proposed or considered in each alternative. In the second case, the standard mitigations are used (1) to develop a baseline for measuring and comparing impacts among the alternatives; (2) to identify other actions and alternatives that should be considered, and $(3)$ to help determine whether more stringent or less stringent mitigations should be considered.

Some of the seasonal restrictions in the standard oil and gas lease stipulations contain the statement, "Thls limitation does not apply to maintenance and operation of producing wells." This statement was included because the stipulations were developed specifically for application to oil and gas leases at the time of issuance, not for activities assoclated with producing wells. At lease issuance, the only action that can be generally contemplated is the possibillty that exploratory drilling may occur somewhere on the lease area. Unfortunately, the provision has been interpreted by some people to mean that the seasonal restriction disappears at the operatlonal stage (l.e., if a producing weli is attained). It must be understood that at both the oil and gas expioration stage and the operation or deveiopment stages, additional site-specific environmentai analyses are conducted and any needed restrictions or mitigations identified become part of the operational or development pian. For example, welis may continue to produce, but related activity may be limited. Thus, it is possible for such seasonai restrictions to continue in effect and be applicable to maintenance and operation of producing wells, if supported by the environmental analyses.

The RMP/EIS does not decide or dictate the exact wording or inclusion of these guidellnes. Rather, the standard guidelines are used in the RMP/EIS process as a tool to help develop the RMP alternatives and to provide a baseline for comparative impact analysis in arriving at RMP decisions. These guidelines will be used in the same manner in analyzing activity plans and other site-specific proposais. These guidelines and their wording are matters of policy. As such, specific wording is subject to change primarily through administrative review, not through the RMP/EIS process, Any further Changes that may be made in the continuing refinement of these guidelines and any develoement of programspocitic standard stipulations will he hand ed in another forum, including appropriate oublic involvement and inout.

\section{PURPOSE}

The purposes of the "Standard Mitlgatlon Guidelines" are (1) to reserve, for the BLM, the right to modIfy the operations of all surface and other human presence disturbance activitles as part of the statutory requirements for environmental protectlon, and (2) to inform a potentlal lessee, permittee, or operator of the requirements that must be met when using BLM-administered public lands. These gulde- 


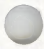

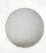

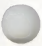




\section{APPENDIX IX}

Legislative and Executive Direction for the Bureau's Wildlife Program

Authority to implement HMPs 
0

0

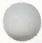




\section{A. Leg1:1at 100}

1. Aleska Nat lood Interest Lands Conservat 10a Act of 1980 (16 D.S.C. 3101, 94 Stat. 2371, P.L. 96-487).

2. Bald Eagle Protect100 Act of 1940 (16 U.S.C. 668 ; 54 Stat. 250; as amended, P.L. 86-70, 73 Stat. 143 (1959), P.L. 87-884, 76 Stat. 1246 (1962), ad P.L. 92-535, 86 Stat. 1064 (1972)).

3. Clean A1r Act of 1970 (42 U.S.C. 1857-58a).

4. Coastal Zone Management Act of 1972 (16 U.S.C. 1451-64). As ameaded, P.L. 94-370, 90 Stat. 1013 (1976).

5. Emergency Wetlands Resource Act of 1986

6. Endangered Spec1es Act of 1973 (16 U.S.C. 1531 et seq.; 87 Stat. 884; P.L. 93-205, a amended; P.L. 94-359, 90 stat. 913 (1974); P.L. 95-212, 91 Stat. 1493 (1977); and P.L. 95-632, 92 stat. 3751 (1978); P.L. 96-159

7. Pederal Land Pollcy and Management Act of 1976 (43 O.S.C. $1701^{\circ}$ et seq.; 90 stat. 2743; P.L. 94-579).

8. Federal Water Pollut 100 Control Act (Clean Water Act) of 1977 (33 U.S.C. 1251 et seq.; 91 Stat. 1566-1611; P.L. 95-217).

9. Hater Quality Act of 1987 (Amendments to Federal Water Pollution Control Act of 1977).

72 Stat. 563).

10. F18h and Wildlife Coordination Act of 1958 (16 0.S.C. 661 et seq.i

11. Fish ad Wild11fe Imrpovenent Act of 1978 (92 stat. 3110; P.L. 95-616).

12. P1shery Conservat 100 and Managenent Act of 1976 (16 U.S.C. 1801-1802, 1811-1813, 1821-1825, 1851-1862, 1882; 90 Stat. 331; P.L. 94-265).

13. Food Security Act of 1985 (Fare B111).

14. Marfoe Mamal Protect100 Act of 1972 (16 0.S.C. 1361-62, 1371-84, and 1401-07, a amended by the P18herles Conservation and Management Act of 1976, P.L. 94-265, 90 stat. 331).

15. Marine Protection, Research, and Sanctuar1es Act of 1972 (33 U.S.C. 1401-44 and 16 U.S.C. 1431-34; 86 stat. 1052).

16. Migratory B1rd Treaty Act of 1918 (16 U.S.C. 703-711; 40 stat. 775, a amended, 49 stat. 1556 (1936), 74 stat. 866 (1960), 88 stat. 190 (1974), 92 stat. 3111-3112 (1978)).

17. Nat lonal Environmental Pol1cy Act of 1969 (42 0.S.C. 4321-47; 83 Stat. 852; P.L. 91-190).

18. Publ1c Rangelands Improvement Act of 1978 (43 0.S.C. 1901 et seq.). 
0

0

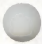


19. Sikes Act of 1960 (16 U.S.C. $670 \mathrm{a}-\mathrm{f} ; 74$ Stat. 1052, as amended, P.L. $93-452$ and 88 Stat. 1369 (1974), P.L. 95-420, and 92 Stat. 921 (1978)).

20. Surface Mining Control and Reclamation Act of 1977 (30 U.S.C. 1201 et seq.; P.L. 95-87).

1269 (1970)).

21. Taylor Graz1ng Act of 1934 (as amended, 43 U.S.C. $315 ; 48$ stat.

22. Jolnt Resolution Regarding Tule E1k, January 1986 (16 U.S.C. 673;

90 Stat. 1189).

85 Stat. 649 ).

B. Executive Orders (EO's).

1. EO 12342 of January 1982 .

2. EO 11990 of May 1977 (Wetlands).

3. EO 11988 of May 1977 (Floodplain Manageaent).

4. EO 11989 of May 1977 (Off-Rosd Feh1cles (ORV's)).

5. EO 11987 of $\mathrm{Mey} 1977$ (Exot1c Organ18ms). 
0

0

0 


\section{A. Leg1slat1on.}

1. Mlask Nat1onal Interest Lande Conservation Act of 1980 (16 0.S.C. 3101: 94 Stat. 2371: P.L. 96-487).

a. Batablishes Nat1onal Conservation and National Recreat ion Areas in Alaska and provides for conservation and preservation of fish and wildife and other values in these and other areas.

b. Title VIII of the Act requires that the opportunity for continued use of subsistence resources on public lands be provided. Cooperation, studies, and reports to Congress specific to subsistence are required.

c. Specific requirements for research on $\mathrm{flsh}$ and wldlife and subsiatence uses on public lands are 1dentifled in Section 812. Specific data requirements, addressing subsistence resources, for reports to Congress are 1dentified in Section 813. Provides strong direction to actively mange fish and wildife resources to provide for subsistence and other uses.

2. Bald Eagle Protect1on Act of 1940 (16 O.S.C. 668; 54 Stat. 250; as amended, P.L. 86-70, 73 Stat. 143 (1959), P.L. 87-884, 76 Stat. 1246 (1962), and P.L. 92-535, 86 Stat. 1064 (1972)).

a. Provides for the cancellation of leases, 11censes, permits, or other agreements authorizing livestock grazing on Pederal lands of persons convicted of violating the Act or any implementing regulation or permit.

b. Establishes penalties for tak1ng, possessing, selling, purchssing, bartering, and certaln other actions pertaining to bald and golden eagles. (The term "take" within the Act includes pursue, shoot, shoot at, wound, k11, capture, trap, collect, or otherwise willfully nolest or disturb.)

3. Clean A1r Act of 1970 (42 U.S.C. 1857-58a). Establishes a mechanisa for control of alr pollution through the malntenance of alr quality standards for public bealth and welfare. As defined in the Act, public welfare includes wldilfe, solls, water, crops, vegetat10n, and other components.

4. Coastal Zone Management Act of 1972 (16 ס.S.C. 1451-64). As asended, P.I. $94-370,90$ Stat. 1013 (1976).

a. Encourages States, wh cooperation of the Federal Governaent, to develop and implement asagement plans to preserve, develop, and, where possible, enhance resources of the Nat1on's coastal zone.

b. Prescribes that managent plans Include:

(1) An 1aventory and designation of areas of particular concern (e.g., areas of "essential habitat for living resources," Including fish and wlidife). 
0

0

0 
(2) Adequate consideration of national interests (e.8., "uldlife refuges," "areas of spec1es and habltat preservation") during siting of fac1lities.

5. Emergency Wetlands Resource Act of 1986.

a. Extends the Wetland Loan Act and delays 1ts repayment. Authorizes the charging of admision fees to certaln units within the Nat1onal Wildife Refuge System and provides for distribution of the subject fee.

b. Provides for the development of a national wetland priority conservation plan to prioritize, on a reglonsl bssis, wetland acquisitions to be pursued.

c. Modifies the Land and Water Conservat1on Act of 1965 to require the Statewide Comprehensive Outdoor Recreation Plans to specifically address wetlands.

d. D1rects the F1sh and W1ldife Service to continue the Nat1onal Wetlands Inventory.

e. D1rects the F1sh and Wildife Service to evaluate the effects of Federal programs on wetlands.

6. Endangered Spec1es Act of 1973 (16 U.S.C. 1531 et seq.; 87 Stat. 884; P.L. 93-205, a a amended; P.L. 94-359, 90 Stat. 913 (1974); P.L. 95-212, 91 Stat. 1493 (1977); and P.L. 95-632, 92 Stat. 3751 (1978); P.L. 96-159 (1979)).

a. Supersedes the Endangered Species Preservation Act of 1966 and the Endangered Spec1es Conservat1 100 Act of 1969.

b. Requires all Federal departments and agencles to ut1lize thelr authorities to conserve species 11sted by the Secretary of the Interior or Secretary of Commerce as threatened or endangered.

c. Requires Federal agencles to ensure that the continued existence of 11sted species 1s not jeopardized and that designated critlcal habltat of listed species 18 not destroyed or adversely nodified.

d. Requires consultation with the Fish and W1ldife Service (FWS) or Nat1onal Marine Fisheries Service if 1t 1s deternined that any BLM action (e.8., r1ght-of-way grant) may affect a threatened or endangered species or 1ts critical habitat.

e. Requires conference wh FWS/MMPS if 1 it 1 deternined that an action 18 11kely to jeopardize the continued exlstence of a proposed threatened and endangered (T/E) secies or result in the extinction or adverse oodification of proposed Critical Habitat. 
0

0

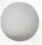



7. $90 \frac{\text { Pederal Land Pollcy and Management Act of } 1976}{\text { Stat. 2743; P.L. } 94-579 \text { ). }}$

a. Requires the development and alntenance of land use plans based oo an Inventory of all public lands and the1r resources.

b. Identifies "flsh and wildlife development and ut1l1zation" as a principal or major land use.

c. Requires that part of grazing fees be spent for "range betterment," including aquatic and terrestrial wildlife habltat enhancement, protection, and malntenance where livestock use occurs.

d. Requires consideration of f1sh and wildlife resources before approval of land exchanges.

e. Authorizes the Secretaries of the Interior and Agriculture to designate areas under the1r jurisdiction and establish time perlods in which no hunting and fishing would be permitted for reasons of public safety, adminlstration, or applicable law.

f. Authorizes the designation of Areas of Critical Environmental Concera to protect and prevent 1rreparable damage to fish and wildilfe, and
other resources.

8. Nelther enlarges nor diminlshes the responsibilities and authoritles of the State for management of f1sh and resident wldilfe.

h. Authorizes 1nvest1gat1ons, studies, and exper1ments-1nvolving the 1mprovement, management, use, and protection of the public lands and their resources.

8. Federal Water Pollution Control Act (Clean Water Act) of 1977 (33 0.S.C. 1251 et seq.; 91 Stat. 1566-1611; P.L. 95-217).

a. The objective of this Act is to restore and aintalo "the chendcal, physical, and blological 1ntegrity of the Nat1on's water" at a level of quality wich provides protection for f1sh, sellfish, wldlife, and recreatlonal use.

b. Requires permits for certaln activities in navigable vaters.

9. Water Quality Act of 1987 (Amendments to Pederal Water Pollution Control Act of 1977).

a. Authorizes funding for water pollution control projects and studies of water pollution problems. 


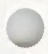

0

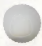



enforcement.

b. Establishes standards and t1metables for pollution designation and

c. Establ1shes a progran to sanage nonpolnt sources of pollut 100 by authorlzing funds to States to prepare reports and plans on waters that are not expected to meet desired water quallty goals.

d. Upon Federal acceptance of reports, States are eligible for grants to 1mplement plans to control nonpolnt source pollution problems.

10. F1sh and W1ldlife Coordinat1on Act of 1958 (16 0.S.C. 661 et seq.; 72 Stat. 56 3).

a. Directs that wldilfe conservation be given equal consideration and be coordinated with other features of water resource development prograns.

b. Requires that possible damage to f1sh and wldlife resources, from work planned in navigable waters and dralnages, be assessed and that measures be adopted for preventing such losses or damages as vell as for development and 1 mprovement of wildlife and flsheries resources.

11. P1sh and W1ldl1fe Improvement Act of 1978 (92 Stat. 3110; P.L. 95-616). Authorizes the Secretary to perwit taking of golden eagle nests wh1ch laterfere w1th resource development or recovery operations.

12. F1shery Conservation and Management Act of 1976 (16 0.S.C. 1801-1802, 1811-1813, 1821-1825, 1851-1862, 1882; 90 Stat. 331; P.L. 94-265).

a. Asserts for the Unfted States Management authority over f1sh and all forms of marine animals and plants (except narine mamals, birds, and migratory spec1es) with1n a 197-m1le conservation zone cont1guous to the $0 . S$.

b. Clsims for the U.S. the author1t1es over anadromous f1sh which spawn in U.S. fresh or estuarine waters, and over certaln sedentary spec1es on areas of the Continental Shelf, extending beyond the conservation zone.

c. Requires preparation of comprehensive fishery anagement plans by reglonsl f1shery management counc1ls, composed of Pederal and State officials. The Secretary of Commerce bs the lead in 1mplementation of this law.

13. Food Security Act of 1985 (Pare B111).

a. Encourages the removal of marginal lands from production and provides various 1ncentives for wetland habltat protect1on and restoration whlle reduc1ng Pederal subsidy costs. 


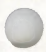

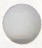

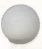


b. Conteins a "swamp buster" provision that withholds subsidies for agricultural products produced on egricultural land converted from wetland after December $23,1985$.

c. Prov1des for conservation set-asides of not less than 10 years for highly erodible lands (that nay be interspersed with wetlands). Also provides for cost sharing for planting cover crops.

d. Provides for Federal Fara Home Loan debt rellef in exchange for 50 -year easements for conservation purposes on lands beld by the borrower.

14. Mar1ne Mammal Protect1on Act of 1972 (16 U.S.C. 1361-62, 1371-84, and $1401-07$, s amended by the Fisheries Conservation and Management Act of 1976, P.L. 94-265, 90 Stat. 331).

a. Establishes a moratorium on the taking, possessing, transporting, selling, and importing of marine mammals or their products, except in f few c1rcumstances (e.8., takings incidental to commercial fisberies operations).

b. Provides the Secretary of the Interlor and Secretary of Commerce principal roles for protecting 8 pecies or populations of cetacea and plonipedia (except walruses), and all other marine mammals, respectively.

15. Marine Protection, Research, and Sanctuar1es Act of 1972 (33 U.S.C. 1401-44 and 16 U.S.C. 1431-34; 86 Stat. 1052).

a. Authorizes the Secretary of Comerce to designate aress of the Outer Continental Shelf as "marloe sanctuaries" in order to promulgate thelr conservation, recreation, ecological, and esthetic values. (BLM would be one of the Federal agencies consulted regarding proposed sanctuaries on the Shelf.)

b. Once a delegation is made, any permits, 11censes, or other authorization 18sued must be certifled by the Secretary of Commerce to be consistent with the Act (e.g., the action does not result in dumping of wastes which would pollute the sanctusiy).

16. Migratory B1rd Treaty Act of 1918 (16 0.S.C. 703-711; 40 stat. 775, as amended, 49 Stat. 1556 (1936), 74 Stat. $866(1960), 88$ Stat. 190 (1974), 92 Stat. 3111-3112 (1978)).

a. Establishes Pederal responsibility for the protection of International migratory bird resources, 1 mplements conventions between the U.S. and other governments (Great Britain, Japan, Mer1co, Russia) and gives the Secretery of the Interior (FWS) authority to regulate hunting of algratory birds. 
0

0

0 
17. Nat1onal Env1 ronmental Pol1cy Act of 1969 (42 U.S.C. 4321-47; 83 Stat.

A. Requires Federal agenc1es to ut111ze a eysteat1c, laterdleciplinary approach to ensure the use of aatural and iocial sciences, and environsental design arte in any planning or decislomaking that alght Impact man's env1 ronment.

b. Establ1shes nat lonal environmental policy to, among other things, encourage productive and harmonlous relationships between man and his environment and to enrich the understand $1 \mathrm{ng}$ of ecological systems and natural processes 1mportant to the Nat1on. P1sh and wildiffe 1s obviously an 1 mportant aspect of any such systems and processes.

c. Requ1res preparat1on of detalled statements on env1ronmental 1 mpacts of proposed major Federal actions that sigalficantly 1apact the quality of the human envi ronment.

18. Publ1c Rangelands Improvement Act of 1978 (43 0.S.C. 1901 et seq.).

a. Directs 1mprovement of rangeland conditions in accordance with land use planning under FLPMA.

b. D1rects development and mantenance of an inventory of range conditions and treads as part of FLPMA's 1nventory process.

c. Requires prior consultation with the FWS, wildife agencles of the State where animals are located, Individuals Independent of Pederal and State government recommended by the Nat1onal Academy of Sclences and other Individuals having sclentific expertise and special knowledge of wild horses and burros, wildife management, and anmal husbandry as related to rangeland management.

d. Provides funding for rangeland 1 mprovements which lncludes providing habltat for wildife.

19. S1kes Act of 1960 (16 U.S.C. $670 \mathrm{a}-\mathrm{f} ; 74$ stat. 1052, as amended, P.I. 93-452 and 88 Stat. 1369 (1974), P.I. 95-420, and 92 stat. 921 (1978)). The basic 1ntent of T1tle II was to extend the Sikes Act authority for wldilfe progran developsent from strictly allitary reservations to public lands adminlatered by the Porest Service and BIY. In essence, $1 \mathrm{t}$ was a congressional mandate for BLY to -. plan, develop, eainta1n and coordinate prograns for the conservat 100 and rehabilitation of wildife, fiah and gane."

a. Title I extends wildife prograns on allitary reservations and provides funding authorization.

b. Title II authorizes the following key elesents for BLM vildiffe progran management: 
0

0

0 
(1) Cooperative agreements subject to the Grants Cooperat 1ve Agreement Act, (P.L. 95-224; U.S.C. 6306 (See BLM Manual Sect1on 1500)) and close work1ng relat1onshipe with State wildilfe agencles; (The S1kes $A c t$ as amended, provides an exemption to the requireaents of the Grants and Cooperative Agreement Act if the work to be done 1s covered by a Babitat Management Plan (BMYP) and the work will be done by the State F1sh and Wildlife Agency (see BLM Manual Sect10n 6521.1)).

(2) Preparat1on and 1mplementation of jolnt BLY-State wildlife agency habltat management plans (HMP's).

(3) Integration of the BLM's Mldilfe program with the Bureau's planning system, environmental assessment, and public lnput and review process.

(4) Implementation of on-the-ground w11d11fe habltat 1mprovement, malntenance, and protection programs.

(5) Protection and management of both Pederal and State-11sted threatened and endangered species.

(6) Establishment of a potent1al hunting and f1shlng stamp progran for State wildife agencles to use-if and when they deem fit.

20. Surface Mining Control and Reclamat1 on Act of 1977 (30 U.S.C. 1201 et seq.; P.L. 95-87).

a. Authorizes the surface mining of cosi in environmentally compatible areas.

b. Establisbes criter1a for designation of lands unsultable for surface mining of coal or other minerals.

c. Provides for reclamat10n of past orphaned surface disturbances.

d. Requires reclamation of disturbed aress.

e. Provides a mechanlsm for State magenent of the Act. (Protect1on and/or reestablishment of $\mathrm{flsh}$ and wldlife habitat is one of the factors that would be considered during the design, assessaent, and impleaentation of reclasation polans, and dur1ng designation of areas unsultable for minfig.)

21. Taylor Grazlng Act of 1934 (as amended, 43 U.S.C. 315; 48 Stat. 1269 $(1970))$.

a. Requires the Secretary to protect, administer, regulate, and 1mprove grazing diatricts created in accordance with the $A c t$. 
0

0

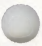


b. Section 2 of the Act 180 requires the Secretary "to ensure the objects of such grazing districts, namely, to regulate thelr occupancy and use, to preserve the land and 1 te resources from destruction or unnecessary infury, to provide for the orderly use, Inprovenent, and developaent of the range."

c. Authorizes the Secretery "to cont inue the study of erosi on and flood control and to perform euch work as nay be necessary to amply protect and rehablilate such areas with1n grazing districts.-

d. Provides for cooperat1on w1th local stocknen assoc1ations, state land of f1c1als, and State agencles engaged in conservatiun or propagation of wldlife which are interested in the use of grazing dietricts for ouch purposes.

e. Provides for hunt ing and flshing in grazing districts in accordance with applicable laws.

22. Jo1nt Resolut1on Regard1ng Tule E1k, January 1976 (16 O.S.C. 673; 90 stat. 1189).

a. Prov1des for the Secretary of the Inter1or, the Secretery of Agriculture, and the Secretary of Defense to cooperate with the State of Callfornia in making 1 ands under the1r respective jurlodictions reasonably avallable for management of Tule elk.

b. Requires the Secretary of the Interlor to submit a report every three years regarding the size and condition of the Tule elk herds and the nature and condition of the1r respective habltats.

23. W11d Free-Rosming Horse and Burro Act of 1971 (16 0.S.C. 1331-40, 85 Stat. $649 \overline{9}$.

a. Requires that management activities for wild horses and burros be carried out in consultation with State wildlife agencies in order to protect the natural ecological balance of all wildife species inbabiting the land, particularly endangered vildilfe.

b. Requires that any adjustents in forage allocations take into consideration the needs of 11 wildife species.

B. Brecut 1ve Orders $\left(\mathrm{BO}^{\prime} \mathrm{s}\right)$.

1. EO 12342 of Jenuary 1982 . Th1s Execut1ve Order peralts effective predator control wh environental safeguards. 
0

0

0 
2. EO 11990 of May 1977 (Wetland 8). Directs Federal agencles to ninlalze the destruction, 1088 , and degradation of wetlands, and to preserve and enhance the beneficial values of wetlands. In adminfstering 1te activities, quallty of vetlands. conat ruct 1on project 111 federally Inlt1ated, flnanced, or peralted minlmize adverse 1macts. Involving Federal vetlo. All leases, rights-of-way, essement, and disposals whlch are consistent with

3. EO 11988 of May 1977 (Floodpla1n Management). Directe each Federal agency to evaluate the potential effects of 1 ts actions on floodplains and to ensure that 1 ts planning programs and budget requests take flood hazards and floodplain mangement lnto account. Pederal agencles are to take action to reduce the rlsk of flood 1088 , to minisize the 1apacts of floods, and to restore and preserve the natural and beneficial values of floodplains.

4. EO 11989 of May 1977 (Off-Road Vehicles (ORV's). Th1s order d1rects heads of Federal agencies to close areas to ORV use wenever it is deternined that use of ORV's is or will cause considerable adverse impact on so11, vegetation, wildife, wildlife habitat, or certain other resources on the of the public lands a a a so authorized to adopt the pollcy that portions and trails.

5. E0 11987 of May 1977 (Exot 1c Organt sm8). D1 rects Execut 1ve agencies, to the extent perwitted by law, to restrict the 1 in roduction and/or 1mportation and funding of exot1c species lnto natural ecosystems on lands they administer. It also encourages States, local governments, and private c1tizens to prevent latroduction of exot1c species. 
0

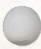

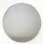




\title{
APPENDIX X
}

\author{
Split Rock Prescribed Burn \\ BLM Environmental Assessment WY-037-EA0-038
}


0

0

0 


\section{ENVIRONMENTAL ASSESSMENT TILE PAGE}

RAWLINS DISTRICT

EA No. WY-037-EAO-038

Name or Title of Action Split Rock Prescribed Burng

File Name, No. and Location GDRA Wildlife Fileg 6711.4

Location: Township 24 North, Range $71 \& 72$ West, County Albany

Resource Area: Great Divide

\begin{tabular}{|c|c|c|c|}
\hline $\begin{array}{l}\text { Authors and } \\
\text { Reviewerg }\end{array}$ & Title & $\begin{array}{l}\text { Assignment } \\
\text { (i.e. Author } \\
\text { or Review) }\end{array}$ & $\begin{array}{c}\text { Initials } \\
\text { \& Date }\end{array}$ \\
\hline Mary Read & Wildlife Biologist & Author & $1 / 2$ \\
\hline huck Reed & Supv. Range Conservationist & Review & $1 / 251$ \\
\hline alt George & Supv, Multi-Resource Specialist & Review & 1.27 \\
\hline im Bottomley & Forester & Review & $1 / 25 / 5$ \\
\hline
\end{tabular}

Activity Code $\mathbf{4 3 5 1}$

WY-03-1791-5 (05/89) 
0

0

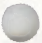


BA No. WY-037-RAO-038

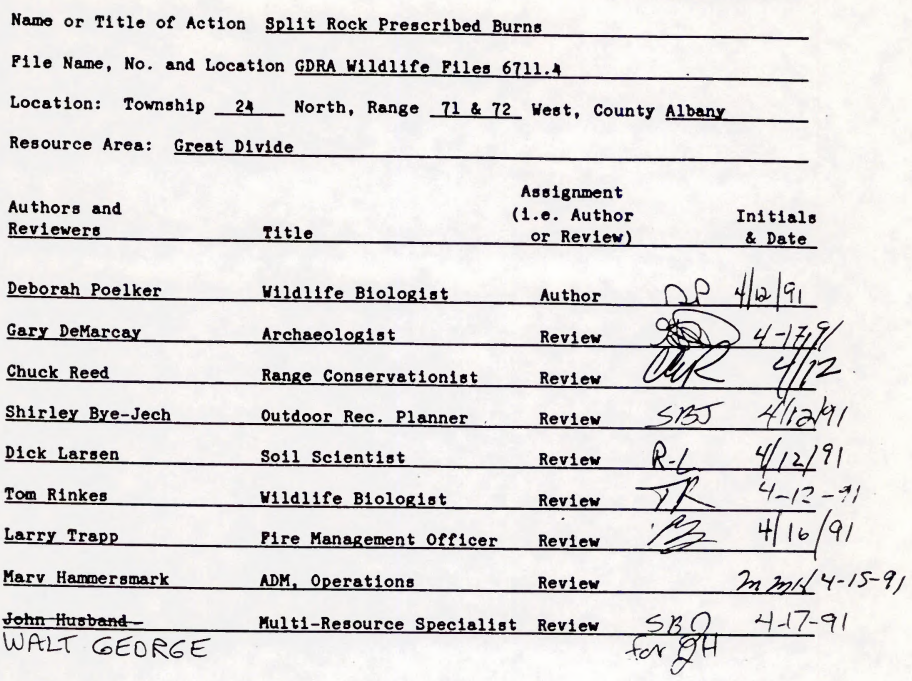


0

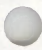

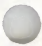


BA No. WY-037-8AO-038

Name or Title of Action Split Rock Prescribed Burns

Pile Name, No. and Location GDRA Wildilfe Files 6711.4

Location: Township 24 North, Range $71 \& 72$ West, County Albany

Resource Area: Great Divide

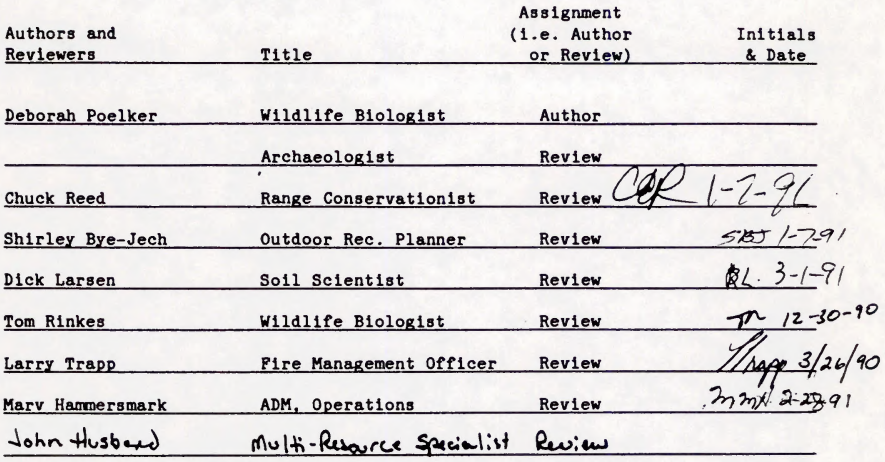

Activity Code 4351

WY-03-1791-5 (05/89) 
0

0

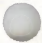


WGPD = Wyoming Game and Plsh Department

WSLO = Hyoming State Lande Offlce

WCRO = Hyoming Cooperative Research On1t

USPS = United States Forest Service 
0

0

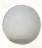


Split Rock Prescribed Burn Environmental Assessment as amended WY-037-EAO-038

The following statements amend the split Rock Prescribed Burn Environmental Asgessment Objectives.

VI. Mitigation and Monitoring

E. At this time there are no cattle or sheep permitted in the burn site area (allotment). If strays occur, they will be promptly removed by the livestock owner. Consultation to inform all adjacent landowners and permittees concerning lost or roving livestock on or near the burn sites will be completed prior to the actual burns in the spring and/or fall of 1993 through correspondence and public information meetings. This procedure will mitigate potential detrimental impacts on grass and forb species production rate, decrease sediment deposits in adjacent water resources, and mitigate increased soil erosion to enhance recovery abilities following the prescribed burn.

At this time it is not reasonably feasible or physically possible to keep wildife off of the area following the prescribed burn, but the exclusion of livestock use will alleviate, as best as possible, any adverse impacts to the area. Post-burn management protocols can monitor natural and man-made processes, which include disease transmisgion as well as accidental direct livestock interaction, with wildlife in thig regource area.

The post-burn management will include the monitoring of the prescribed burn to study and manage in the reasonable foreseeable future the abundant, high quality, diverse habitat resources for optimal forage use by variation of population size and sex-age composition of wildlife in the immediate future and livestock at a later date. In addition, the coevolution of the fauna and flora in relation to the natural dynamics of both fauna and flora production, predators, diseases, physical environments, emigration and immigration processes, variations in fauna/flora conditions and variations of range use (e.g. habitat abandonment and/or development) will be monitored and evaluated in a cooperative venture between the BLM and the WYGF to determine present and future management decisions for the resource area. 
0

0

0 
Decision Record/Rationale

WY-037-EAO-038

Split Rock Prescribed Burns

I. Proposed Action

The proposed action is to prescribe burn sagebrush/grass in the spring and felled timber in the fall within a 400 acre perimeter area in 1993. Burns will be conducted by common mechanical means. The prescribed burns will not be conducted until weather and moisture conditions are suitable to confine the fire to the predetermined area. The primary objective of the burn is to improve habitat conditions for the Duck Creek subherd of the Laramie Peak bighorn sheep herd in the Laramie Peak Wildlife Habitat Area, 25 miles west of Wheatland.

The proposal is located in T. 24 N., R. 72 W., Section 25 and 36 and T. $24 \mathrm{~N} .$, R. 71 W., Section 31. The proposed action is consistent with the Great Divide Resource Management Plan.

II. Alternatives Considered

A. Preferred Alternative

The proposed action is the preferred alternative.

B. Other Alternatives

1. No Action.

2. Burn the proposed area in the fall.

III. Decision and Rationale

The decision is to implement the proposed action as identified in the attached EA (WY-037-EAO-038).

The action will provide a higher quality and quantity of available forage for the bighorn sheep using the Split Rock Mountain and Duck Creek areas during the spring, summer, and fall seasons.

IV. Conclusions

Based on the attached EA analysis, as amended, there is sufficient data to support a Finding of No significant Impact (FONSI). There are no irreversible or irretrievable commitment of resources. No resource or environmental values will be substantially impacted by the proposed action. Therefore, no EIS is necessary.

v. Mitigation and Monitoring

Post-burn management requires the exclusion of livestock use for a minimum of two full growing seasons to enable plants to gain carbohydrate reserves, increase production of leaf matter, and increase soil cover to reduce soil movement and erosion. The area will be monitored and evaluated in a cooperative venture between the BLM and WYGF to determine present and future management decisions for the Resource Area.
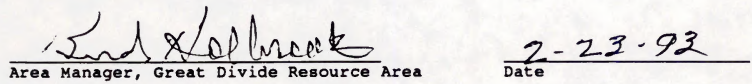
0

0

0 
Split Rock Prescribed Burns

WT-037-BAO-038

I. Purpose and Need

The following are the prescribed burn objectives.

1. Inprove forage quality and quantity on public and adjacent state land for bighorn sheep, elk and wule deer by improving grass/forb production, Increasing new palatable shrub production and reducing stagnant shrub growth.

2. Improve bighorn sheep feeding sites adjacent to escape terrain and nursery areas.

3. Reduce the young ponderosa pine regeneration in the burn units to provide visual migration corridors for blghorn sheep to escape cover or habltat not currently used (historical use areas).

4. Provide uneven aged forage classes and edge effect by conducting mosalc pattern prescribed burns.

Rocky Mountaln blghorn sheep (Ov1s canadensis canadensis) were re-introduced Into the Laranie Peak area of east central Wyoming in 1964 (Bohne 1989). As of June 30, 1989, 168 blghorn sheep have been released in the Laramle Peak D.A.D. Data Analysis Un1t (DAU). Bighorn sheep released near Laramle Peak were transplanted from the Whiskey Mountain herd near Dubols, Wyoming. In spite of these transplants, the Laramle Peak sheep herd appears to be declining (Bohne 1989).

The Wyoming Game and Fish Department (WGPD) has set the strategic plan objective for the Laramie Peak bighorn sheep herd at 500 animals and the 8 trategle harvest objective at 24 rams annually. However, since the first hunting season In 1969, no single year harvest has exceeded 7 rams (Bohne 1989). The current population is estimated at 227 sheep, Including 20 sheep released in January 1989 near Marshall.

The Wyoming Cooperative Pishery and Wildlife Research Onit is conducting a study of the Laranle Peak blghorn sheep herd. Objective number flve of this study is to deternine the potential to enhance and expand the range of this herd by vegetative manipulation. Prescribed burns will be used to increase forage quality and quantity on sumer and winter ranges. Transects will be sampled on burns to determine percent canopj cover, vegetation height and composition. Porage will be clipped to deteralne crude protein and total digestible nutrients. These values will be compared to forages clipped on unburned areas.

Cook et al. (1989) stressed the need to evaluate fire as a tool for bighorn sheep habitat management. Spring burns apparently rejuvenate decadent plant communities most efficlently and result in alnimal first-year depression of herbaceous and shrub production (Cook et al. 1989). Mortality of desirable, 
0

0

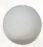


declduous browe can be minimized by burning in spring during relatively cool temperatures and higher soll molsture conditions. Porage quality, crude proteln and digestibllity, greatly Increased on burn sites the flret year after burning (Cook et al. 1989). Smith (1988) suggested that benefite derived froe burning may last ten to flfteen years.

Sheep strongly select burned areas but observed selection is highly seasonal and varlable among areas, reflecting physical site conditions and Juxta-position of burns to other habitat components selected by shoep (Cook ot al. 1989). Accordingly sheep select burned hab1tate in winter only if they occur on south to west aspects at lower elevations where winter forage 1s accessible (Cook et al. 1989). Cook et al. (1989) suggest that prescribed burns should be 1nterspersed within lambing/nursery areas to provide the greatest benef1t to lactating ewes.

In addition to the vegetative benefits derlved from spring burns, these burns are also safer from a fire control standpolnt in that they would provide much greater ease of control due to molst solls and snow accumulations which act as natural fire breaks.

\section{Descrlption of the Proposed Action and Alternatives}

A. Proposed Action

The proposed action 1s to prescribe burn in the spring approximately 400 acres of sagebrush/grass, mountaln shrub, and young ponderosa plne. The burns would be located within the 1500 acres Indicated on the attached map, of the proposed burn area and land ownership. Burns would be conducted in one to two days in the late winter or spring depending upon weather conditlons. Due to the unpredictable weather and snow accumulation conditions in the area, burns would be executed on an opportun1st1c basis. Those areas sultable for burning, when all other parameters are favorable (10. snow accumulations, wind, etc.), would be 1 gnited. The prlority areas to burn are located in the south and central portions of T. 24 N., R. 71 W., Section 31. Selection of the burn area was based on blghorn sheep observations and historlcal use of the area, topography, fuel breaks, and snow accumulation areas.

Burns would be 1gnited with common mechanical methods. Ixisting breaks in vegetation or natural barriers such as rock outcrops or snow drifts would be used as control lines or burn unit boundarles. No f1re lines would be constructed unless absolutely necessary. Black lines would be burned in low flre behavior perlods such as early morning.

Burns would be conducted cooperatively by BLM personnel, Hyoming Game and P1sh Department personnel, and US Forest Service personnel.

The proposed action 1s consistent with the Great Divide Resource Management Plan. 
0

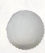

0 


\section{B. Alternatives}

1. No action - Rejection of the proposal.

2. Burn the proposed area in the fall.

\section{Affected Bnvironment}

Bnvironmental components that would not be affected by the proposed action are alnerals, fisherles, prime or unlque farmlands, wetlands, floodplains, wilderness areas, ecologlcal significant or critical areas such as ACBC' ' (areas of critical environmental concern), wld or scenic rivers, Native American religlous concerns, and threatened or endangered specles. Because these resources are not affected they will not be analyzed in this document. The proposed action would not produce any
solid or hasardous waste.

Timber harvest in this area is not cost effective at this time because of the high cost of road construction in the rugged rock terrain. Mature timber would be damaged very little fro a low intensity spring burn. Therefore, forestry will not be analyzed further.

Currently, grazing does not occur in the proposed burn area. Due to the rugged terrain, no significant livestock use is expected in the future. Therefore, environmental Impacts on livestock grazing will not be

There are no known cultural sites in or near the project area. There are no known standing structures. No surface disturbance or fireline construction is expected. Therefore, cultural resources would not be affected and will not be further analyzed.

A1r

- Alr quality in Duck Creek and Split Rock Mountaln area is considered excellent. Wind 18 common and helps malntain high alr quallty.

Prevalling winds are from the southwest-west.

\section{Water}

Three perennial streams and numerous intermittent streams occur in the project area. The perennial streams are Duck, Ashley, and Pole Creeks. Average annual precipitation is 15 to 19 1nches with the most precipltation occurring as snow during winter wonths.

\section{So11:}

So1ls survey Information was from the Albany County Soll Survey. The proposed burns occur primarily in the Redfeather - Lakehelen - Rogert, Rock Outcrop - Cathedral, and Bojle - Alderon - Rock Outcrop soll 


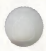

0

0 
complexes. The water erosion hasard is moderate in all of the complexes except the Redfeather - Lakehelen - Rogert complex where it is sovero. Wind erosion hazard 1s slight for all so1ls except the Redfeather Lakehelen - Rogert complex where it is moderate.

These so1ls occur on slopes ranging frow 5-50 percent.

\section{Vegetation}

Approximately one-third of the area 18 forested. Most of these areas consist of a ponderosa pine overstory and an understory comprised of varlous shrub, grass and forb specles lncluding western snowberry, creeplng Juniper, western and bluebunch wheatgrass, Parry danthonia, starry cerastiun, flowery phlox and western yarrow.

Another one-third of the area is comprised of varying densities of b1g sagebrush and grass spectes. In th1s type, b1g sagebrush 18 the dominant overstory shrub with an understory of varlous grasses and forbs including needleandthread, western wheatgrass, needleleaf sedge, sandberg bluegrass, rose pussytoes, halry goldaster, and selaginella ("dense clubmoss").

The remalning one-third of the area is a highly diverse area compound of a varlety of shrubs, grasses, forbs, and scattered conifers. Some of the shrub specles 1nclude b1g sagebrush, mountaln mahogany, antelope b1tterbrush, Douglas and rubber rabbltbrush, and fringed sagewart. Grass specles Include Idaho fescue, needleand thread, sandbers bluegrass, pralrie junegrass and western wheatgrass. The scattered tree species Include limber and ponderosa pine. Porb spectes are numerous. Riparian zones are found within all these types.

\section{H11d11fe}

The Split Rock Mounta1n and Duck Creek area provide habltat for a varlety of game and nongame wlldife. The proposed project area 18 cruclal winter/yearlong habltat for bighorn sheep, elk, and wule deer. Other specles whlch occur are blue grouse, red squirrel, cottontall rabb1t, black bear, and mountaln lion. A wide varlety of raptors use the area for nesting, feeding, migration, and, In some cases, wintering.

\section{V1sual Resources}

The area is highly scenlc and falls within a Class II visual resource management category. A Class II area 18 one where changes in any of the basic elements (form, line, color, or texture) caused by management activity should not be evident in the characteristic landscape. 
0

0

0 
A. Proposed Action

\section{$\underline{\text { A1r }}$}

Prescribed burning would cause a temporary (1-3 day) reduction in visibllity during the period of the burn each year. Winds would disperse the smoke created by the burns shortly after the completion of the burn in a fasion that would meet or exceed amoke dispersion requirements under the clean alr act.

\section{Water}

Impacts of elre on water are largely secondary, resulting from Plre's Impact on vegetation. A slight increase in sediment would be expected to reach perennial waters in the project area. The impact on water should not be significant due to the scattered locations of the burn and buffers created by leaving riparian areas unburned.

\section{So11s}

Initially, erosion rates may Increase, however, this Increase is expected to be minimal due to the nature of the soll and because the amount of physical disturbance to the soll structure would be Inappreciable. Brosion rates would decrease as cover reached pre-burn levels. Revegetation of a spring burn would probably occur within 30 days of the burn.

Vegetative cover would meet or exceed preburn measurements within two to three years.

Although these solls are classifled in the moderate to severe erosion hazard, fleld examination of the Duck Creek wildfire of Septemer 1974 did not indicate any notable erosion problems.

\section{Vegetation}

The resistance of plants to f1re varles greatly between species, but also depends heav1ly on flre conditions, speciflcally high intensity and duration. B1g sagebrush 18 a non-sprouter and 18 highly susceptible to flre Injury through the killing of the camblum layer at the base of the stem. Sprouting shrubs and trees, such as snowberry, serviceberry, and rabbltbrush generally have high survival and increased production because they can sprout from lower depths of the stem. Por the sprouting specles, it is important to have good soll molsture to assure a high percentage of survirability. Soll molsture would normally be highest in the spring. Due to the current low blomass production of rabbltbrushes In the burn units, resprouting of these species should not occur in significant quantity to inhibit regrowth of bunchgrasses. Reestablishment of big sagebrush after the flre would depend upon 
0

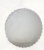

0 
b1g sagebrush seod sources and the rate at which other species reoccupy open areas that previously supported b18 sagebrush. B1g sagebrush would not be expected to reinvade the sites in significant densities for a inimum of ten years.

Roduced production of grass and forb specles would be expected to be alnimal and short term. Bluebunch wheatgrass production would return to pre-burn production in 1 to 3 years and possibly double production in future years. Burn plan objectives and prescription would be written to protect more fire sensitive species.

Production of true wountaln mahogany, bitterbrush, and serviceberry were monitored during the Cook ot al. (1989) study. Production of true mountaln mahogany plants appeared to decline the first year after flre but was followed by rapld recovery. Cook ot al. (1989) found that spring burns enhance laitial recovery of shrubs, particularly bitterbrush and serviceberry showed high survival and profound production increase on per-plant basis.

Cook's ot al. (1989) data suggests that cool spring burns w1ll benef1t perennial grasses but burns in other seasons may have varlable offects.

Prescribed burning would reduce plne regeneration and have pruning effect on the lower branches of larger trees, with a crown base at or below flre helght. Reestablishment of plne regeneration would take a minimum of 15 years, depending upon avallable seed source and ilcrocllmate.

\section{Hildife}

The burn would Improve forage quallty, palatabllity, avallab1lity, and Increase big game use of the area by blghorn sheep and ell. Hule deer use of the area may decllne slightly for a short period if a reduction in the density of shrubs (serviceberry, mountaln mahogany, and bitterbrush) occurs.

Burning in a mosalc pattern would provide uneven aged forage classes, thus perpetuating accessible high quality forage for b1ghorn sheep.

Burning can Improve production and palatability of 1mportant big game forage species in grasslands (Peek et al. 1979). Burning of standing dead, dry, leached litter will remove a barrier to grazing of green forage, consequently Improving palatablity and avallabllity (Hobbs and Spowart 1984). Hobbs and Spowart (1984) found that prescribed burning elevated the concentration of proteln and in vitro digestible organic matter in winter diets of mountain sheep and mule deer feeding in grassland communities. Anderson (personal communication 1984) found a crude protein increase of approximately 65 percent occurring the flrst year following a burn for bluebunch wheatgrass wh th a subsequent return to near pre-burn levels three years following the burn. 
0

0

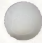


Hobbs and Spowart (1984) found in their study that the effects of flre on diet quality resulted from changes in ungulate diet selection rather than improvements in the quality of individual forages. Differences in the amount of green grass in ungulate diet accounted for much of the enhancement in diet quality in this study. Irwin and Cook (1987) belleve that the Increased avallabllity of green grasses and forbs following wildfire in the North Platte River Valley would benefit blghora sheep.

Now spring growth has been shown to start several weeks earlier on burned areas, than on unburned range, consequently such burned ranges are preferred over unburned ranges by wildife and 11 vestock (Daubenire 1968). With the improved palatab111ty and earlier new spring growth on burn areas blghorn sheep and elk would profer burnod areas over unburned areas. Signiflcantly heavier ungulate use can be expected to occur for the first few years on the burn areas, as compared to the unburned rangelands, but would decline with time (Peek ot al. 1979).

Sheep movement is somewhat restricted by the presence of ponderose pine. The reduction of pine regeneration and the limb pruning of larger trees would 1mprove visibility and provide more secure migration corridor for bighorn sheep.

Conducting the burn would displace animals currently using the area in the short term. A temporary loss of forage would occur from the burn, but would be short term with the start of spring growth or fall regrowth.

The proposed burns are located in high use areas and adjacent to escape terrain and nursery areas. Spring burns appear to cause the least mortality of desirable resprouting deciduous shrubs which are major constituents of the sheep's diet in late summer and fall (Cook et al. 1989), therefore benefitting lactating ewes. During the sumwer ewes with lambs are dependent on rock outcrops. Cook et al. (1989) found that ewes on Douglas Creek left burned areas with high quallty forage one week prior to lambing and went to nursery areas with a poorer quality forage. Stagnation of sheep populations in the Bncampment herd has boen highly attributed by (Cook ot al. 1989), to poor summer/fall diet resulting in poor resistance to disease and consequential high lamb nortallty. Horejs1 (1972) found that the nutritional plane of the ewe effects colostrum quality, which in turn can affect resistance of lambs to viral and bacterial infections. Therefore, wth increased forage quality, near nursery aress, lamb grouth and survival could also increase.

\section{Visual Resources}

A visual resource contrast rating was written for the proposed burns. Contrast ratings assess how the proposed action would affect the basic elements (form, 11ne, color, and texture) of the 
0

0

0 
existing landscape features. These ratings are then compared to maximua acceptable impact $11 \mathrm{mlt}$ to for a VRM Class II area. It was determined that the visual resources would only be temporarily affected and that the class would not change (VIsual Resource Contrast Rating - At tachmont No. 2).

B. Alternative

1. No Action

The 1mpacts projected for the proposed action would not occur. With the selection of the no action alternative forage quality and avallability would continue to be in a degraded state for the maintenance of the Laramie Peak blghorn sheep herd. The current downward trend of the population may continue until the population is unable to alntaln itself. If the blghorn sheep population is unable to malntaln itself, opportunities for hunting and sightseeing of the blghorn sheep would be lost.

2. Burn the proposed area in the fall

If the fall burn alternative were implemented rather than the spring burn, the degree of control over the burn would be great $1 \mathrm{y}$ reduced and the risk of the flre "getting away" Increased. Also more manpower would be required as holding forces, with the absence of snow accumulations to act as natural fire breaks.

A fall burn would be of higher intensity than apring burn, therefore Increasing the chance of flre injury and mortality to sprouting shrubs and bunch grasses.

Revegetation of a fall burn would occur following spring thaw and snow melt and could expose unprotected soll to erosion for a 60 to 90 day perlod. Fall burning would be more likely to cause greater amounts of erosion, than a spring burn, because of runofe from snow melt and a longer period of exposure to water erosion.

All other consequences would be the same as for a spring burn.

V. Irreversible or Irretrievable Commitwents of Resources

There are no irreversible or irretrievable commitments of resources wh the proposed action. If the no action alternative were selected the present blghorn sheep population may not remain self-sustaining and may require more transplants of blghorn sheep to malntaln 1tself. 
,

0

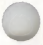




\section{Mit1gation and Monltorins}

A. The BLM would obtaln a "Construction and Improvement Permit" from the Hyoming State Land and Parm Loan Offlce, with concurrence form Irue Ranches, lessee of the State Section 36, prior to burning units on state lands. Th1s 18 provided the proposed action 18 selected for Implementation.

B. Before an 1gnition is Initlated, the following persons and agencles would be contacted: Albany County Sheriff, Wyoming Highway Patrol, Albany County P1re Department, USPS - Laramle Peak Ranger District, PM, Hyoming Department of Bnvironmental Quallty - A1r Quallty Division, Wyoming Game and Flsh Department, and Jack Mixon, private land owner adjacent to planned burns.

C. Buffer zones of undisturbed vegetation at least 100 feet wide would be left along water courses. Guldelines developed by the 0.3 . Porest Service would be ut1lized to protect riparlan areas.

The following slopes and corresponding buffer zones would be malntalned:

\begin{tabular}{c} 
Percent Slope Range \\
\hline $0-20$ \\
$20-30$ \\
$30-40$ \\
$40-50$ \\
$50-60$
\end{tabular}

\begin{tabular}{c} 
Buffer W1dth \\
\hline 100 \\
180 \\
280 \\
400 \\
520
\end{tabular}

D. The proposed action would be monitored by the wildife blologist, Great DIv1de Resource Area, WGFD, and the Unlversity of Hyoming Cooperative Hildilfe Research Unit. Monitoring would Include: vegetation production and cover, pre- and post-burn, and response of radlo telemetered blghorn sheep pre- and post-burn.

\section{vI. Consultation/Coordination}

The following Individuals outside the BLM, Rawlins District have been contacted regarding their Input into the proposed action.

Terry K1llough

Joe Bohne

Rich Guenzel

Tim Byers

Bob Gurney

J1m whalen

Bryce Lundell

Dan Hengel

Ray Kunkins

Toby Hingert

Don Sherard
Laramle District Supervisor WGPD

Wildife Blologist WGPD

Wildilfe Blologist WGFD

Wildife Blologist OSPS

Hab1 tat Mgmt. Coordinator, Region 3 WGFD

Senior Appralser usLo

State Porester uslo

Research Assoclate WCRO

Private Landowner Wheatland

State Land Lessee True Ranches

Private Landowner Wheatland 
0

0

0 


\section{RBPBRRNCBS}

Anderson, L. 1984, Personal Communication with Toa Rinkes currently of the Great Divide Resource Area, Myoming, Bureau of Land Management, regarding prescribed burning for blghorn sheep. Anderson is with Salmon District, Idaho, Bureau of Land
Management.

Daubenmire, R. 1986 "Bcology of Fire In Grasslands." In: Advances in Bcological Research, Vol 5. Bdited by J. B. Crags. New Work: Acadenlc Press.

Hobbs, N. T. and Spowart, R. A. 1984, "Bffects of Prescribed Pire on Nutrition of Mountain Sheep and Mule Deer During Winter and Spring." Journal of Wildilfe Management $48(2)$ : 551-560.

Hores11, B. 1972, "Behavioral Differences in Blghorn Lambs (Ovis canadensis canadensis shaw) During Years of $\mathrm{HIgh}$ and Low Survival." Ph.D. D1ssertation, Univ. Calgery, Calgery. 265 pp.

Irwln, Larry L. and Cook, John G. 1984, "Platte River Blghorn Sheep Winter Range." Journal of Range Management 32(6):43-432.

Selp, D. R. and Bunnall, P. L. 1985, "Range Burning, Stone's Sheep and the Leaky Bucket." In: Plre's Bffects on Wildilfe Hab1tat - Symposiun Proceedings, Karch 21, 1984, Pp. 44-47. General Technical Report INT-186. M1ssoula, MT: USDA-PS Intermountain Research Station.

Salth, S.G. 1988. "Dlet quality of Wintering Bighorn Sheep on Burned and Onburned Vegetation Types, South Pork Shoshone River, Hyoming." M.S. Thesis, Univ. of Wyoming, Laramie, 95 pp. 


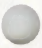

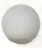




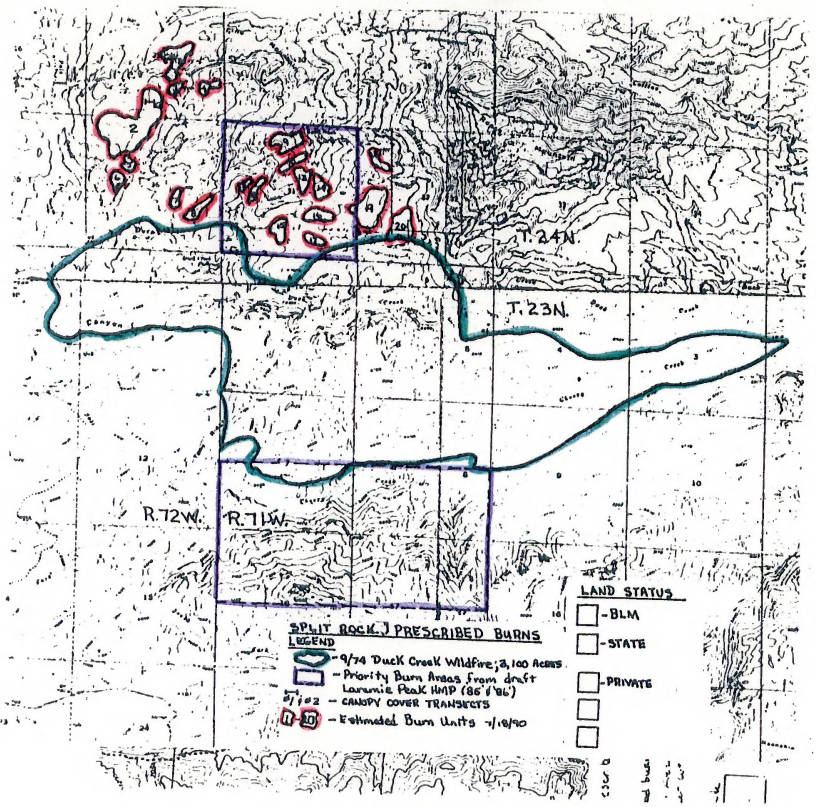



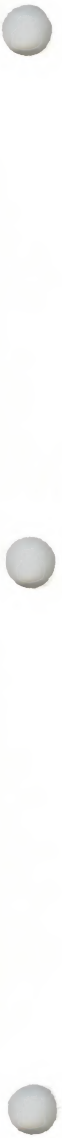


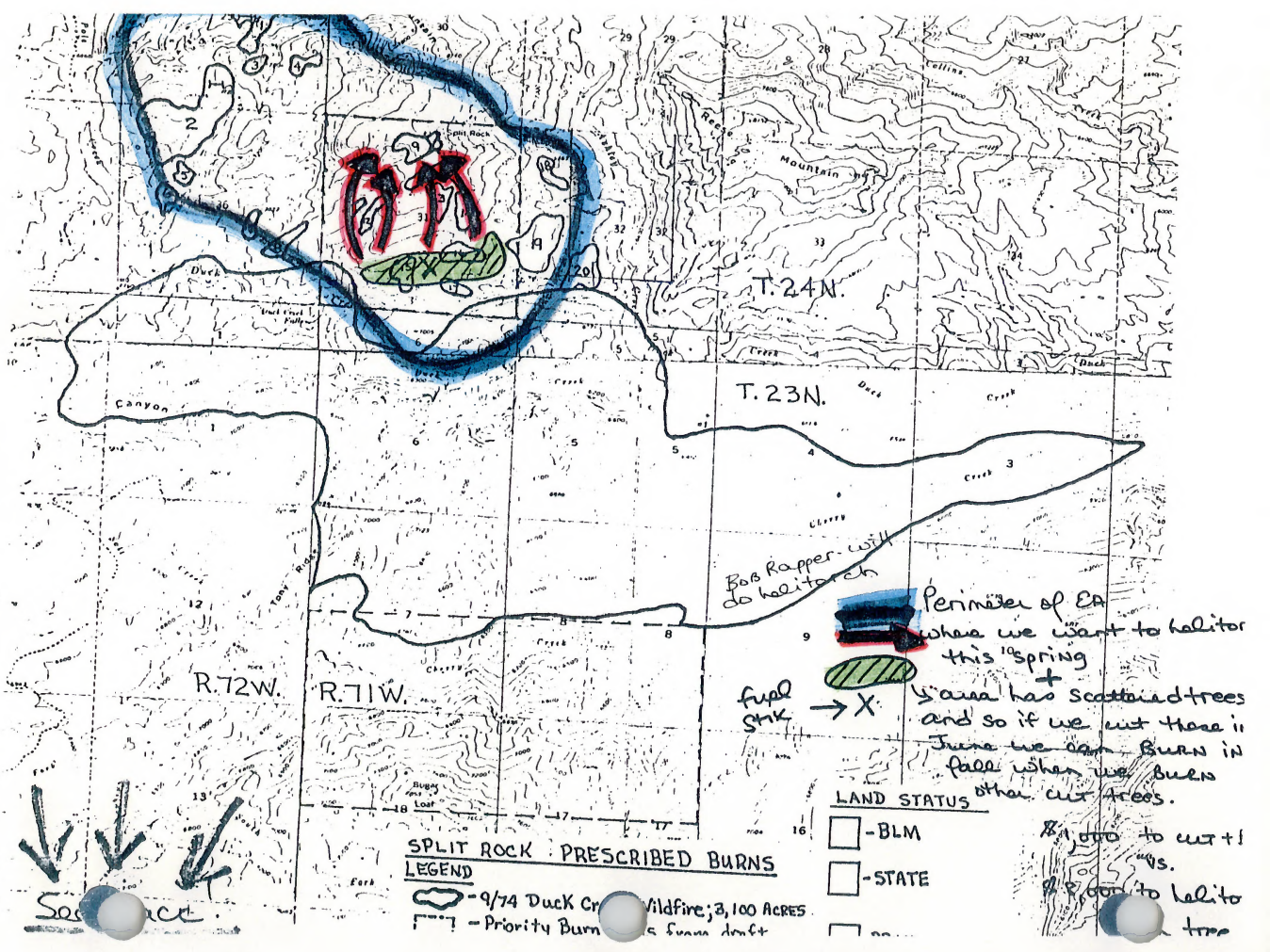



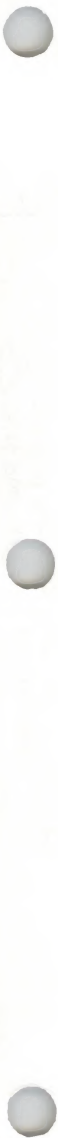
Decision Record/Kationale

WY-U37-EAO-USO

Split Kock Prescribea Burns

I. Proposed Action

Tne proposed action is to prescribe burn in the late winter or spring approximately 4 UU acres. Burns would be conducted by common mechanical means. It weather is suitable, burns should occur in the spring of 19yl. Primary objective of the burn is to improve habitat conditions for the Duck Creek subinerd of the Laramie Peak bighorn sheep herd.

The proposal is located in T. 24 N., R. 72 W., Section 25 and 36 and T. 24 N., R. 71 W., section 31. The proposed action is consistent with the the Great Divide Resource Management Klan.

11. Alternatives Considered

A. Preferred Alternative

The proposed action is the preferred alternative.

๖. Otner Alternatives

1. No Action.

2. Burn The proposed area in the fall

I1I. Decision and Rationale

The decision is to impletnent the proposed action as identified in the attached EA (WY-037-EAO-030).

The action will provide a nigher quality and quantity of available forage for the bignorn sheep using the Split Rock Mountain and Duck Creek areas during the spring, sunmer, and fall seasons.

IV. Conclusions

based on the attached EA analysis, there is sufficient data to support a Finding or No Significant Impact (FUNSI). There are no irreversible or irretrievable commitment of resources. No resource or environmental values will be substantially impacted by the proposed action.

Theretore, no EIS is necessary.

v. Mitigation and Monitoring

Mrtigation identifled in the EA, Section VI, will be used.
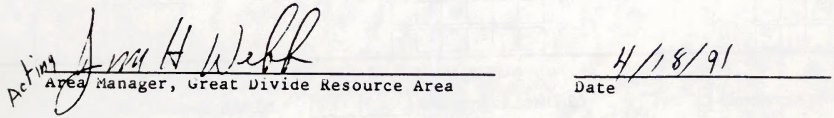


\section{RANC .AND IMPROVEMENT PROJECT SYST. (RIPS)}

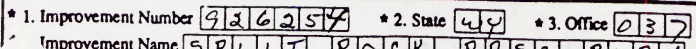

- Improvement Name 5 S jonstruction Code N

* 9. Type Plan 3

*12. Primary Units \begin{tabular}{|l|l|l|l|l|}
\hline & & & $247 \%$ \\
\hline
\end{tabular}

14. Secondary Units \begin{tabular}{ll|l|l|l}
\hline & & & & \\
\hline
\end{tabular}

-16. Meridian 016

*17. Township 01244 IN

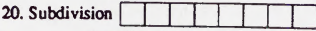

23. Lat Sec \begin{tabular}{l|l|l|}
\hline & 1 & \\
\hline
\end{tabular}

26. Long Sec

29. Fence Type $\square$

32. Chemical Type $\square$

35. T \& E Species

38. Animal Spec/1 $O$ O $V|C| C$

41. Water Storage

44. Undefined Field/1
8. Construction Agreement 1

-10. Type Habitat T

- 13. Geo County $\square \square$ ? Albonny

* 15. Geo State WV

21. Lat Deg $\square$

24. Long Deg $\square \square \square$

27. Project 1

Improvement Details
- 18. Range $0171 / 10 \mathrm{~W}$
30. Misc Facilities $\square$

33. Seeding Method $\square$

36. Plant Spec/1

39. Animal Spec/2 C $|E| E|L|$

42. Watershed Tillage Method

45. Undefined Field/2
- 4. Corr. Jutión Year 119996

- 6. Improvement Code VIM

-11. Principal Mgt Objective 1 /

-marks SIPIRIIING $|P| R|E| S|C| R|I| B|E| D|~ B I U| R W$

19. Section $0 / 311$

22. Lat $\mathrm{Min}$

25. Long $M$ in

28. Project 2
1

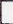

31. Plant Control Method P/F

34. Species Benefitted $B \mid G$

37. Plant Spec/2 43. Water Fling Number

,

47. Line $\mathrm{Nr}$

50. Wildlife Mgt Area

48. Allot Number

51. WH\&B Herd Mgt Area $\square \square \square$

49. Watershed Mgt Area

\section{BLM Costs}

52. Sub-Activity

1

54. Materials

55. Equipment

\begin{tabular}{|l|l|l|l|}
\hline 4 & 3 & 5 & 1 \\
\hline & & & \\
\hline & & & \\
\hline
\end{tabular}
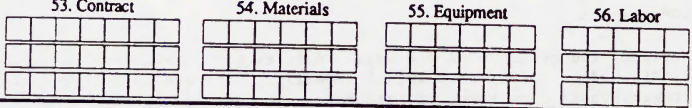

57. Work Month

Cooperator Contributions
58. LN
59. Type
60. Cooperator Name

$\square$ 61. Deposited Contributions

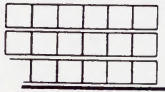

64. Maintenance Agreement 1

67. Primary Units

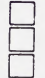

.

.

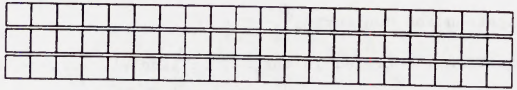

62. Undeposited Materials

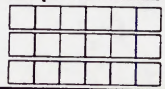

63. Undeposited Lab \& EQ

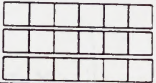

Maintenance Record

65. Date Last Inspected

- 66. Maintenance Cycle 25

68. Secondary Units

69. Fiscal Year Maintained 
Part A (To be filled out by applicant)

Project Name: Split Rock Prescribed Burns

Lase No.:

SA NO. WY-O37-EAO-O3B

Applicant: many kead

Date Inventory Determination Requested 3-25-94

By: M. Read

Location: T. 24 \%., R. 7I W., Sec. $31,1 / 4,1 / 4$

'I. 24 M., R. 72 W., Sec. $25,-1 / 4,-1 / 4$

'1. 24 M., R. 72 W., Sec. $36,-1 / 4,-1 / 4$

'1. - M., R. - W., Soc.

USGS Quadrangle: Davidson Flats, Reese mt.

(attach quad map with proposed project dellneated)

County:

Albany

Project Description: Prescribe burn sagebrush/grass in sprior and

lodgepole pive (Beetle kiled) / filled timber in the fall.. Date Project Needed: $5-1-94$

Part

Class III Inventory will be required for this project.

Class III Inventory will not be required for this project.

Dellareay 2.25 .94

Area Archaeologiot, ireat Divide

Part C: Section 100 Statua

Date report received

Cultural resources found II Yes II Ho

4.H. eligible resources found? II Yes |Z Ho

SHPO concurrence I Yes Date___ No I I I necessary

Cultural clearance ILT Yea I- No

Stipulations: No ground disturbing activify allowed

Lidellarean 2-25-94

Area Archaeologiaff Great.Divido 
UNITED STATES

DEPARTMENT OF THE INTERIOR

BUREAU OF LAND MANAGEMENT

VISUAL CONTRAST RATING WORKSHEET
Date $7-17-90$

District Kawlins

Resource Area Great Mivide

Activity (program) 4351

SECTION A. PROJECT INFORMATION

1. Project Name

SPII RoCK

ourescribed Burns

2. Key Observation Point None

3. VRM Class

\section{II}

4. Location

Township $\frac{24}{1} N$

Range $72 w_{i}$

Section 31,32

5. Location Sketch

See map in ₹A.

SECTION B. CHARACTERISTIC LANDSCAPE DESCRIPTION

\begin{tabular}{|c|c|c|c|}
\hline & 1. LAND/WATER & 2. VEGETATION & 3. STRUCTURES \\
\hline 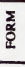 & $\begin{array}{l}\text { Extremely rugged } \\
\text { terrain with rocky } \\
\text { atcrops. }\end{array}$ & $\begin{array}{l}\text { scatteres pine; } \\
\text { sagebrush aud grass } \\
\text { pockets; i hrub pockets }\end{array}$ & none \\
\hline 祘 & $\begin{array}{l}\text { mountainous, } \\
\text { irregular }\end{array}$ & $\begin{array}{l}\text { sca fored, } \\
\text { irvegular }\end{array}$ & - \\
\hline$\frac{2}{8}$ & grays, beiges, browns & $\begin{array}{l}\text { beiges, browns, } \\
\text { greeus, grays }\end{array}$ & - \\
\hline ' & coarse & coarse & - \\
\hline
\end{tabular}

SECTION C. PROPOSED ACTIVITY DESCRIPTION

\begin{tabular}{|c|c|c|c|}
\hline & 1. LAND/WATER & 2. VEGETATION & 3. STRUCTURES \\
\hline 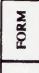 & No change & 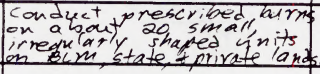 & None \\
\hline 鹃 & - & irregular & - \\
\hline$\frac{1}{8}$ & - & $\begin{array}{l}\text { backs, brawns-short term } \\
\text { browns, greens, beiges, } \\
\text { grays - Laug term }\end{array}$ & - \\
\hline 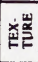 & 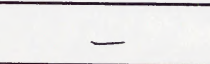 & $\begin{array}{c}\text { Smooth to goutly } \\
\text { coarre }\end{array}$ & - \\
\hline
\end{tabular}

SECTION D. CONTRAST RATING $\square$ SHORT TERM ULNG TERM

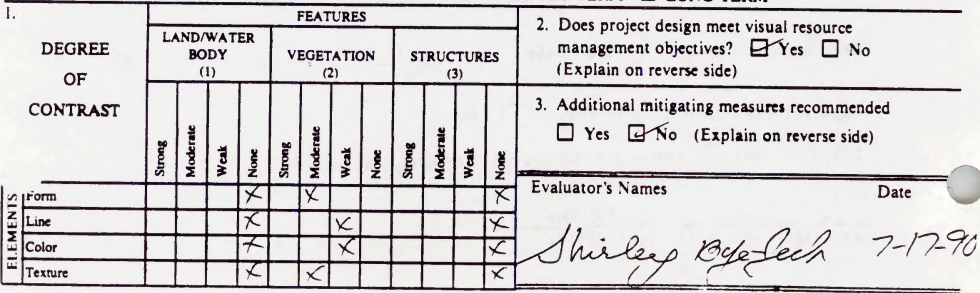



To: Area Manager, theat Biride R.A.
From: Whildife Biol viget
Subject: Request for Threatened or Endangered Species Evaluation (Effect/No Effect) and Biological Evaluation on Other Wildiffe Species

Please evaluate the proposed action for the possible existence of threatened or endangered species (see attached map). Also, please evaluate proposed action for conflicts with other wildlife species.

Project or

Company Name (if applicable) Spoit Rock Preccilled Burne Reference No. (lease, case, project, EAR, etc.) WY-037-EA0-038 Location: T.24N,R.71W, \& R.72W. Description of Proposed Action:

Qreocribe burnabout 247 arde over a 5 pear period beginning in the bpring of 1991. Burnewill be conducted in the tpring only. Quyson Qardes $7 / 18 / 90$

Response: Data Review and Determination of Impact on Threatened or Endangered Species and/or other wildlife

To: Area Manager, Areat Aivide

Th1s proposal and relative data have been analyzed as to the impact of the proposed action upon the species listed on the reverse side:

IXI A field examination of the proposed disturbance was conducted by the Area Wildlife Blologist

XI The Area Wildlife Biologist reviewed the overlay retrieval system for Threatened and Endangered species and other wildife, and could find no conflict. However, the site will be checked during the field/pre-site examination.

The T\&E analysis indicates that there would be a (no effect) ( situation as a result of approving the described action. Initiation of formal consultation (is not) recommended.

The wildife analysis produced the following results. Please include the attached stipulations indicated on the reverse side: 
0

0 


\section{APPENDIX XI}

Land Use Constraint's Relative to the WGFD's "Strategic Plan for the Comprehensive Management of Wildlife in Wyoming (1984 - 1989)" 
0

0

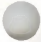


INTRODUCT ION

WYOMING STATUTE 23-1-103 stipulates: All wildlife in Wyoming is the property of the state. It is the policy of the state to provide an adequate and flexible system for control, propagation, management, protection and regulation of all Wyoming wildlife.

THE WYOMING GAME AND FISH DEPARTMENT, UNDER THE DIRECTION OF THE GAME AND FISH COMMISSION, IS RESPONSIBLE FOR THE FULFILLMENT OF THIS MANDATE. THE EXPRESSED LEGAL CHARGES TO THE COMMISSION AND DEPARTMENT ARE AS FOLLOWS (WYOMING STATUTE 23-1-302):

(1) To fix season and bag limits, open, shorten or close seasons on any species or sex of wildlife, except predatory animals, predacious birds, protected animals, and protected birds, in any specified locality of Wyoming, and to give notice thereof:

(2) To establish zones and areas in which trophy game animals may be taken as game animals with a license or in the same manner as predatory animals without a license, giving proper regard to the livestock and game industries in those particular areas;

(3) To acquire lands and waters in the name of Wyoming by purchase, lease, agreement, gift or devise, not including powers of eminent domain, and to develop, improve, operate, and maintain the same for the following purposes:

(a) Fish hatcheries, rearing ponds, game farms and bird farms;

(b) Management of game animals, protected animals and birds, fur bearing animals, game birds, fish and their restoration, propagation, or protection;

(c) Public hunting, fishing, or trapping areas as places where the public may hunt, trap, or fish in accordance with laws;

(4) To acquire easements and construct suitable access roads leading to public lands and department lands and waters acquired pursuant to section 23-1-302 (c) of the Statutes;

(5) To sell or exchange land, water, or other property which is no longer of any practical use to the commission;

(6) To capture, propagate, transport, buy, sell, or exchange any species of game animals, bird, fish, fish eggs, or fur bearing animal needed for propagation or stocking purposes, and to exercise control over undesirable species and protected species;

(7) To direct the capture of any of the wildlife of Wyoming in localities where species are abundant and to transport and distribute any wildlife as in the judgment of the commission is for the best 
0

0

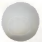


interest of wyoming;

(8) To authorize the Chief Game Warden or his designee to kill any wildlife in Wyoming when in the judgment of the commission the killing is necessary or when the animals or birds are doing substantial damage to property. The animals or birds so killed may be sold or otherwise disposed of within wyoming;

(9) To make suitable provisions for the feeding of the game animals, birds, and fish of wyoming in such localities as may be deemed necessary;

(10) To enter into cooperative agreements with educational institutions and other agencies to promote wildife research;

(11) To enter into cooperative agreements with federal agencies, corporations, associations, individuals, and landowners for the development of state control of wildlife management and demonstration projects;

(12) To supervise the protection, management, and propagation of fish and all fish culture of a public nature and the fish hatcheries now owned or established in the future by wyoming;

(13) To grant licenses for scientific or educational purposes to capture, take, or ship out of Wyoming, under the supervision of the comission, such wildlife or nests or eggs of non-predacious birds as the commission may deem proper. The comission shall limit the number of any species so taken and establish appropriate compensation;

(14) To prescribe the requirements and form for the licenses and tags provided for in this act, to issue licenses under the provisions of this act, to make regulations for the sale and record of licenses and tags, and to distribute licenses and tags only to persons authorized by the commission to issue them;

(15) To require record keeping and the submission of reports of any specified information from any type of commercial operation or business authorized under this act;

(16) To provide for the enforcement of this act;

(17) To provide for the employment of office and field help to administer this act. Salaries shall be determined and fixed as provided by law;

(18) To open game preserves for hunting when they are overstocked or a serious shortage of feed exists. These preserves shall be so managed that they do not cause overstocking or other damage to the surrounding area;

(19) To designate as protected, game, or predatory, any species not designated in Section 23.1-1 of the Statutes, and to establish rules and regulations necessary for control of the species so designated. The designations may apply to portions of or the entire state;

(20) To authorize the collection, classification, and dissemination of such statistics, data and information as in its discretion will tend to promote the objects and purposes of this act;

(21) To establish check stations to check licenses and to establish kill or catch reports, and to designate the location of check stations in yearly hunting regulations; 
0

0

0 
(22) To promulgate such orders as the commission considers necessary

to carry out the intent of this act;

(23) To create new divisions or abolish any existing divisions within the department as necessary to effectively administer and enforce this act;

(24) To approve and make public budgets and establish policy for the department;

(25) To regulate the use of power vehicles on land owned or leased by the comission;

(26) To regulate or prohibit the importation of exotic species, small game animals, fur bearing animals, protected animals, game birds, migratory birds, protected birds, and fish into Wyoming, and to regulate the importation of big or trophy game animals into Wyoming;

IN ADOITION TO THE ABOVE POWERS AND DUTIES, THE WYOMING LEGISLATURE, THROUGH STATUTES 41-13-101 TO 41-13-218 AND 23-2-107 HAS DIRECTED THE DEPARTMENT:

(a) To provide for and regulate the registration and licensing of watercraft operating on all waterways of wyoming and to enforce all provisions of the Wyoming Boating Act.

(b) To institute and coordinate a statewide course of instruction in safety and competency in handling firearms. Toward this end, the Department has instituted a 5-year plan for hunter education.

IMPLICIT IN THESE CHARGES IS THE RESPONSIBILITY OF THE DEPARTMENT TO PROVIDE THE PUBLIC WITH OPTIMUM BENEFITS FROM THE AVAILABLE WILDLIFE RESOURCE. TO THIS END THE FOLLOWING STATEMENT OF POLICY HAS BEEN ADOPTED BY THE WYOMING GAME AND FISH COMMISSION :

The wide-open spaces of wyoming are part of the American heritage. The existence of these areas and their associated wildlife has far-reaching significance for human welfare. For people living here and in other areas of the country, this resource offers a measure of personal solace and relief.

In this context, it must be emphasized that wildlife and habitat are inseparable. No wild species can be maintained effectively outside of a biotic community in which it can perform its natural functions. Therefore, irreversible changes in native fauna and flora should be discouraged. If such changes are permitted, they should be after the most searching study and then only in areas where the impact on land, water, and wildlife is minimal and mitigation is guaranteed. 
0

0

0 
Projections for the future suggest that the human population of the state may more than double between 1970 and 2000. Conservative estimates indicate that the desire for outdoor recreation is likely to triple. This impact will be further compounded by habitat losses associated with increasing human population and industrial development. In the face of these pressures, it is imperative that the Department apply professional expertise in identifying and conserving wyoming's wildife resources. This responsibility is twofold: 11 we must strive to protect wyoming's wild animals and, in general, the natural scene and 21 equally important is the responsibility to provide quality outdoor experience with wildife.

Toward these ends the following policy objectives will be followed by the wyoming Game and Fish Department:

1. While recognizing that other legitimate demands exist for the use of land and water resources, it is the statutory responsibility of this Department to be the principal proponent of the maintenance and perpetuation of wildlife in Wyoming.

2. Wildlife conservation within this state is the responsibility of the Game and Fish Commission and the professional function of the Game and Fish Department. However, this is prefaced by the fact that wildlife resources are owned by the people of wyoming. Therefore, consistent with biological constraints, this resource will be managed with consideration for the interests and desires of the public. Both consumptive and nonconsumptive uses of wildlife will be structured to produce desired and worthwhile human experiences.

3. To produce and maintain optimum populations of wildlife on all lands and waters in wyoming suitable as wildlife habitat and consistent with other uses of such lands and waters and to utilize through hunting and fishing the available crop of those wildlife species appropriately classified by statute.

4. To maintain for all wildlife the best possible habitat conditions consistent with other uses, improve wildlife habitats which are open to the public and encourage private landowners to do the same.

5. To keep wildlife populations in balance with local forage supplies and commensurate with conflicting uses, and manage on the basis of available forage, resorting to artificial feeding only in previously approved on-going programs or on an emergency case-by-case basis.

6. It is a policy of this Department to provide opportunity for the public to take wildlife, but not to guarantee 
0

0

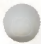


fish or game to every license holder.

7. It is a policy of this Department, subject to the existing legal constraints, to control wildlife populations which are damaging land or property with sound programs for public hunting.

8. In areas where species overlap, the primary species will be identified and the major management activities will be directed toward the welfare of the selected species where conflicts exist.

9. It is a policy of this Department to endorse or participate in the regulation of predatory animals only on the basis of documented local wildlife needs.

10. "Put-and-Take" stocking operations have little relationship to the maintenance of wildlife, and they should not be carried on at the sole expense of the general license buyer. It is the Department's position that these operations should be supported by special use fees collected from those who participate in "Put-and-Take" harvests.

11. The importation and use of exotic plants and animals by this Department will be undertaken only after intensive study, appropriate agreements with the agencies concerned and adequate public information. In any case, exotics will be introduced only if they can be controlled.

12. Recognizing that social values derived from wildlife are so great and diverse that it is neither appropriate nor adequate to finance management of this resource entirely from license holders, and realizing these funds will not be sufficient in the future to meet costs of managing the wildlife resources for the people, all additional funding opportunities must be pursued. These will include not only the pursuit of additional funding alternatives but also application of responsible management practices leading to conservation and maximization of results from existing funds.

13. Recognizing that approximately half of the land area of Hyoming is controlled by the Federal Government and thus owned by all the people of the United States, the Department honors the need to insure use opportunity for nonresidents.

14. Regulations governing the use of wild animals will be limited to those regulations essential for the orderly protection, management and enjoyment of the resource. 
0

0

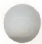


GREAT PRESSURES ARE BEING BROUGHT TO BEAR ON WILDLIFE RESOURCES AS WYOMING IS DEVELOPED AND COMPETITION FOR LANDS AND WATERS INCREASES. NOW, MORE THAN EVER, FOR THE SERVICE OF AN EVER-INCREASING POPULATION, MANAGEMENT MUST BE FUTUREFOCUSED AND PURPOSEFUL. MANAGEMENT IN THE PUBLIC INTEREST MUST BE BASED ON AN UNDERSTANDING OF OUR LONG-TERM CAPABILITIES, CHANGING SOCIAL AND ENVIRONMENTAL CONDITIONS, AND THE BEST POSSIBLE APPRAISAL OF EXPECTATIONS FOR THE FUTURE. RESPONDING TO THIS CHALLENGE, THE WYOMING GAME AND FISH DEPARTMENT HAS DEVELOPED A COMPREHENSIVE PLANNING SYSTEM AS AN AID TO DECISION MAKING IN AN EFFORT TO INCREASE DEPARTMENTAL EFFECTIVENESS. THIS SYSTEM IS DESIGNED TO SERVE THE FOLLOWING PURPOSES :

1. IT FORCES COMPREHENSIVE AND CRITICAL EVALUATION OF THE ENTIRE SPECTRUM OF DEPARTMENT OPERATIONS.

2. THE PLANNING PROCESS GIVES CONTINUITY TO DEPARTMENTAL ACTIVITIES REGARDLESS OF PERSONNEL CHANGES.

3. THE PLAN ALERTS OTHER RESOURCE USERS TO THE NEEDS OF WILDLIFE MANAGEMENT PROGRAMS, THUS STRENGTHENING THE DEPARTMENT'S POSITION IN NEGOTIATIONS WITH OTHER RESOURCE USERS.

4. THE PLANNING PROCESS PROMOTES ACTION RATHER THAN REACTION BY ORIENTING PROGRAMS TOWARDS THE ACHIEVEMENT OF DEFINITE OBJECTIVES.

5. THE PLAN PROVIDES A MEANS fOR PUbLIC EVALUATION OF THE DE PARTMENT'S OBJECTIVES AND PHILOSOPHIES.

THE PLANNING SYSTEM CONSIDERS THE ENTIRE SPECTRUM OF GAME AND FISH OPERATIONS AS THEY RELATE TO FULFILLMENT OF THE DEPARTMENT'S LEGAL RESPONSIBILITIES AND STATED POLICIES. AREAS OF CONFLICT AND NEEDS FOR COOPERATION AND COORDINATION WITH ALL LEVELS OF GOVERNMENT, PRIVATE ENTERPRISE, AND THE PUBLIC AT LARGE ARE IDENT IFIED THROUGHOUT.

THE GOALS AND OBJECTIVES IN THIS PLAN ARE BASED ON EXISTING LAWS, COMMISSION POLICY, PROJECTED INCREASES IN WILDLIFE-RELATED RECREATION, AND BIOLOGICAL CAPABILIT IES OF THE STATE'S LANDS AND WATERS CONSISTENT WITH OTHER LEGITIMATE USES OF THESE RESOURCES. PUBLIC INPUT IS SOLICITED AT HEARINGS PRIOR TO CHANGES IN REGIONAL OBJECTIVES AND ALSO AT MEETINGS CONCERNING SEASON SETTING.

PROBLEMS AND STRATEGIES WERE DERIVED FROM INPUT OF DEPARTMENT PERSONNEL, CONSULTATION WITH LAND MANAGEMENT AGENCIES, AND EXTENSIVE QUESTIONNAIRE SURVEYS DESIGNED TO DETERMINE THE DESIRES AND ATTITUDES OF RESIDENT HUNTERS, FISHERMEN, AND CENERAL HOUSEHOLDS. THE INFORMATION IN THIS PLAN IS PRESENTLY THE BEST AVAILABLE, HOWEVER, THE DEPARTMENT RECOGNIZES THAT CONSTANT UPGRADING, EVALUATION AND REVISION ARE NECESSITIES. OPPORTUNITIES FOR REVIEW OF THE DRAFT OF THIS DOCUMENT HAVE BEEN GIVEN TO RESOURCE MANAGEMENT AGENCIES WITH WHOM THE DEPARTMENT FREQUENTLY INTERACTS, INCLUDING THE U.S. FISH AND WILDLIFE SERVICE WHOSE GRANTS-IN-AID PROVIDE A SIGNIFICANT PORTION OF THE DEPARTMENT'S FUNDING FOR SPECIAL PROJECTS COVERING A NUMBER OF INDIVIDUAL MANAGEMENT PROGRAMS.

UPDAT ING OF THE PLAN IS AN ONGOING PROCESS, BUT OFFICIAL REVISIONS OF THE PLAN WILL BE PKINTED EVERY THREE YEARS. 
PLANNING IS A VALUABLE TOOL IN RESOURCE MANAGEMENT, BUT LIKE ANY TOOL IT WILL SERVE NO USEFUL PURPOSE IF LEFT ON A SHELF. THIS PLAN WILL BE EFFECTIVE ONLY WITH COMPLETE ADMINISTRATIVE SUPPORT AND COOPERATION FROM ALL DEPARTMENT PERSONNEL, STATE AND FEDERAL LEGISLATURES, OTHER GOVERNMENT AGENCIES, AND THE GENERAL PUBLIC.

UNDER THE GUIDELINES OF THE PREVIOUS PLAN (VOLUME II, 1978-1983) PROGRESS WAS MADE TOWARD ATTAINMENT OF THE OBJECTIVES OUTLINED IN THAT DOCUMENT AND TOWARD THE DEVELOPMENT OF VIABLE SOLUTIONS TO PROBLEMS. IN ADDITION TO ROUT INE OPERATIONS, THE DEPARTMENT WAS INVOLVED IN MANY SPECIALIZED PROJECTS AND ACTIVITIES. CONTINUING APPEALS WERE MADE FOR LEGISLATION TO APPROVE ALTERNATE FUNDING AND INSTREAM FLOW PROPOSALS AND EVALUATIONS WERE MADE OF THE POTENTIAL IMPACTS OF PROPOSED LAND USE CHANGE PROJECTS ON TERRESTRIAL AND AQUATIC HABITAT. STUDIES WERE UNDERTAKEN TO PROVIDE INFORMATION ON SUCH SUBJECTS AS STREAM FLOW, POPULATIONS, HABITAT AND DISEASE. EFFICIENCY WAS IMPROVED WITH THE INCREASED USE OF COMPUTER SYSTEMS IN MANY PHASES OF DEPARTMENT OPERATIONS. COMMUNICATIONS WITH THE PUBLIC WERE AIDED BY THE PRODUCTION OF MOTION PICTURE AND SLIDE SHOWS, NEW PUBLICATIONS AND NEW EDITIONS OF EXISTING PUBLICATIONS. LAND AND ACCESS ACQUISITIONS WERE MADE TO PROTECT KEY HABITAT AREAS AS WELL AS TO PROVIDE RECREATIONAL AREAS FOR CONSUMPTIVE AND NON-CONSUMPTIVE USE. OF SPECIAL INTEREST WERE PROJECTS UNDERTAKEN TO ASSESS THE STATUS OF THE BLACK-FOOTED FERRET, TO REINTRODUCE PEREGRINE FALCONS AND TO MAKE TRIAL INTRODUCTIONS OF FORAGE FISH SPECIES. THOSE INTERESTED IN MORE SPECIFIC INFORMATION ARE ENCOURAGED TO REVIEW THE DEPARTMENT'S ANNUAL REPORTS FOR THE YEARS $1979-1983$. 
0

0

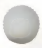




\section{STRATECIC PLAN FOR THE WYOMING GAME AND FISH DEPARTMENT}

Wildlife found in Wyoming and managed by the Department includes approximately 100 species of mammals, 322 species of birds, 78 species of fish, 12 species of amphibians, 23 species of reptiles, and an undetermined number of mollusk and crustacean species.

Sportsmen spent an estimated 5,460,227 days hunting and fishing in the state during 1982 and contributed approximately $\$ 223,034,619$ to the state's economy. By 1988 , hunting and fishing participation is expected to exceed 7,000,000 days, and hunting and fishing expenditures should exceed $\$ 300,000,000$ (in 1982 dollars).

In addition to hunting and fishing, some species of Wyoming's wildlife resource are subject to commercial harvest in the form of trapping or commercial fishing.

Also, wildlife is widely utilized in such nonconsumptive endeavors as observation and photography. A national survey conducted during 1980 indicated that these activities resulted in over $1,029,320$ days of recreation and $\$ 24,400,000$ in expenditures throughout the state for that year.

These totals $(1,029,320$ recreation days; $\$ 24,400,000$ in expenditures) underscore the importance of wildlife resources, both aesthetically and economically, to the state of Wyoming. Their conservation and management is a responsibility of awesome magnitude and great privilege. In this context, it is the goal of the Wyoming Game and Fish Department to:

...manage all Wyoming wildlife and, in cooperation with private landowners and public land management agencies, manage their habitats in such a manner that all populations of native wildife species maintain density and distribution consistent with the welfare of the resource, which will provide optimum sustained recreational, scientific, educational, aesthetic, and economic benefits to the public. 
0

0

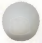


A great many problems face the conservation of Wyoming's wildlife and the attainment of this goal. Many of these problems are specific to certain areas or individual populations but all may be categorized into the 11 general problems 1 isted below. Included with each of these problems are strategies deemed appropriate for addressing them. Those desiring information on problems and strategies concerning individual species or specific populations should contact the Planning Section of the Wyoming Game and Fish Department.

Problems and Strategies

1. CONFLICTING USES OF LAND AND WATER ARE ALTERING HABITATS AND CAUSING A REDUCTION IN WILDLIFE CARRYING CAPACITY.

A. Develop and implement more effective means of environmental surveillance.

B. Develop and/or implement alternatives, preventative measures, compensation, or mitigation for all projects and practices which diminish the quality or quantity of wildlife habitat.

C. Coordinate efforts with land management agencies to insure adequate consideration for wildlife in long range plans.

D. Seek legislation that insures wild and free-ranging populations of wildlife in Wyoming.

E. Work with other agencies and individuals to insure land and water use practices are in harmony with the needs of wildlife.

2. THE RAPID INCREASE IN WYOMING'S HUMAN POPULATION WILL RESULT IN INCREASED DEMAND FOR WILDLIFE-RELATED RECREATION.

A. Develop and implement methods whereby recreational opportunity can be provided to as many people as possible while still maintaining quality and diversity of wild ife-related recreation.

B. Determine the effects of increasing human impacts on wildlife population dynamics and distribution and work to reduce these impacts.

C. Increase the emphasis on redistribution of wildlife users.

D. Work to increase populations of desired wildlife species which are below the carrying capacity of available habitat or below current population objectives.

3. THE PROBLEMS, RES PONSIBILITIES AND COSTS OF WILDLIFE MANAGEMENT ARE INCREASINC FASTER THAN THE FISCAL RESOURCES TO SUPPORT NECESSARY RESPONSES TO THESE CHALLENGES.

A. Develop and implement more efficient technologies, administrative procedures and mariagement systems. 
B. Maintain all Department facilities in the most efficient manner possible.

C. Seek sources of additional revenue.

D. Seek legislation which provides for more flexibility in Department fund ing.

4. CERTAIN LANDS AND WATERS OF THE STATE HAVE PHYSICAL, CHEMICAL AND BIOLOGICAL CONDITIONS WHICH ARE NOT CONDUCIVE TO THE PRODUCTION OF DESIRABLE WILDLIFE SPECIES.

A. Develop and implement more efficient methods for the control of undesirable species.

B. Develop and implement methods for the control of wildlife diseases.

C. Develop and implement methods to overcome the limiting factors in these areas and increase wildlife production.

5. MUCH OF THE WILDLIFE-RELATED RECREATIONAL OPPORTUNITY IS UNAVAILABLE TO THE GENERAL PUBLIC DUE TO A VARIETY OF ACCESS PROBLEMS.

A. Work for better Department-public-landowner relations in an effort to increase access on and across private lands.

B. Seek acquisitions and easements that are beneficial to the public.

C. Seek cooperative agreements with agencies, corporations, and individuals which provide for recreational access.

D. Work to increase public interest and awareness in underutilized areas and species.

E. Work with land management agencies to increase awareness of available public lands by proper marking and mapping.

6. MANY MANAGEMENT PROGRAMS SUFFER DUE TO POOR COMMUNICATION BETWEEN THE DEPARTMENT, OTHER AGENCIES AND THE GENERAL PUBLIC.

A. Increase emphas is on public information and education programs designed to inform the public and other agencies of the needs of wildlife and the principles behind the Department's new and ongoing programs.

B. Develop and maintain better lines of communication between the Department and other agencies, corporations and statrs.

C. Give recognition to funding from federal aid programs.

7. MANAGEMENT PROGRAMS ARE SOMETIMES GOVERNED BY ENFORCEMENT AND DAMAGE PROBLEMS, POLITICS, PROTECTIONISM, AND SPECIAL INTEREST GROUPS RATHER THAN SOUND BIOLOGICAL PRINCIPLES AND PUBLIC BENEFITS. 
0

0

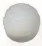


A. Work to provide administrators with better information on wildlife populations and public preferences so that decisions can be made and justified on a more objective basis.

B. Increase emphasis on communicating to the general public, as well as to special interest groups, the requirements of wildlife, the rationale for management actions, and the need for hunter ethics.

C. Conduct the research necessary to better understand ecological principles, processes and life histories, and the effects of management actions.

8. THE EXTENT AND VALUE OF NONCONSUMPTIVE USES OF WILDLIFE RESOURCES IS NOT WELL UNDERSTOOD.

A. Develop the information base necessary to determine the extent and value of nonconsumptive uses of wildlife.

B. Develop areas, materials and facilities designed to enhance public enjoyment, understanding and appreciation of wild animals in their natural habitat.

9. SOME PERSONS ABUSE WILDLIFE-RELATED RECREATION PRIVILEGES AND IGNORE LAWS DESIGNED TO PROTECT WILDLIFE RESOURCES.

A. Maintain an effective law enforcement cadre to minimize these abuses .

B. Emphasize hunter ethics and the rationale for laws and regulations in public contacts and publications.

C. Seek active public participation and support in the enforcement of wildlife laws and regulations.

10. SOME WILDLIFE USERS DEMAND HIGH COST PROJECTS TO MAINTAIN POPULATIONS OF SOME SPECIES ABOVE THE NATURAL CARRYING CAPACITY OF THEIR HABITAT.

A. Emphasize the high cost of artificial animal production systems and the possible biological and sociological detriments of these projects.

B. Develop and implement methods whereby the users of high cost production projects pay their fair share of the management costs.

11. SOME SPECIES OF WILdLIFE CAUSE PROBLEMS AND/OR ECONOMIC LOSSES ON PRIVATE PROPERTY.

A. Work to maintain animal damage at a minimum level.

B. Continue efforts to develop techniques by which the extent of wildlife damage may be accurately assessed and fairly compensated. 
0

0

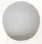


This Strategic Plan for the Comprehensive Management of Wildlife in Wyoming is a part of the planning system developed by the Wyoming Game and Fish Department for structured problem-solving and the attainment of wildlife objectives.

For purposes of organization and clarity, this document is composed of several sections :

I. BIG GAME (pp. 15). This section covers the 10 species of mammalian game classified by state statute as either big or trophy game animals. Antelope, mule deer, white-tailed deer, elk, moose, bighorn sheep and Rocky Mountain goat are managed on the bas is of individual populations or herds (a herd is defined as a discrete group of animals which has minimal interchange with adjoining groups of the same species). There are currently 201 identified herds with plans being made for several new divisions. Maps showing the locations of these herds are included with each program narrative that follows.

The remaining species in this category (black bear, grizzly bear, mountain 1 ion) are managed on the basis of individual, administratively determined management areas which are illustrated with the respective program narratives.

Individual inventory files are maintained for each herd/management area. These files contain information on past population trends, current population estimates, management objectives, problems and strategies, supply and demand, harvest statistics, economic value data, distribution, etc. From these files a sumary sheet was prepared for each species following the format found in this document. Those wishing more detailed information than that contained herein are urged to contact the Planning Section, Wyoming Game and Fish Department, Cheyenne, Wyoming (307/777-7461).

II. SMALL GAME (pp. 43). This section covers the approximately 50 species of small game birds and mammals. Included are 8 species of upland game birds, approximately 36 species of migratory game birds, and 6 species of small game mammals. Species in this category are managed on the bas is of individual, administratively determined management areas. A map showing the locations of these areas precedes tie small game section.

Individual inventory files are maintained for each management area. These files contain information on manament objectives, problems and strategies, supply and demand, harvest statistics, economic value data, distribution, etc. From these files a sumary sheet was prepared for each species (or group of species) following the format found in this document. Those wishing more detailed information than that contained herein are urged to contact the Planning Section, Wyoming Game and Fish Department, Cheyenne, Wyoming (307-777-7461).

III. SPORT FISHERIES (pP. 62). This section covers the management of Wyoming's aquatic resources to provide sport fishing recreation. Sport fisheries are managed on the bas is of the major drainages in the state and these are illustrated with the program narrative. 
0

50:

0

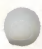


Individual inventory statistics are compiled for specific waters within these drainages. These inventories contain information on location, flows, species present, fishing pressure, supply and demand, etc. Those wishing more detailed information than that contained herein are urged to contact the Planning Section, Wyoming Game and Fish Department, Cheyenne, Wyoming (307/777-7461).

IV. OTHER LICENSED USES OF WILDLIFE (pp. 76). This section includes furbearers, commercial fisheries, and raptors. The species included are those which are subject to regulated harvest or capture but not classified as game animals. Inventory files are maintained for each of the programs presented. These files contain information on managment objectives, problems and strategies, supply and demand, harvest statistics, distribution, etc. From these files a sumary sheet was prepared for each program following the format found in this document. Those wishing more detailed information are urged to contact the Planning Section, Wyoming Game and Fish Department, Cheyenne, Wyoming (307/777-7461).

v. NONGAME WILDLIFE (PP. 83). This section covers nonconsumptive uses of the entire spectrum of wildlife in Wyoming. Over $535 \mathrm{species}$ of vertebrate animals alone are believed to occur within the state during all or part of the year.

Current knowledge of all these species is sumarized in several Department publications. Those wishing more detailed information than that contained herein are urged to contact the Planning Section, Wyoming Game and Fish Department, Cheyenne, Wyoming (307/777-7461). 

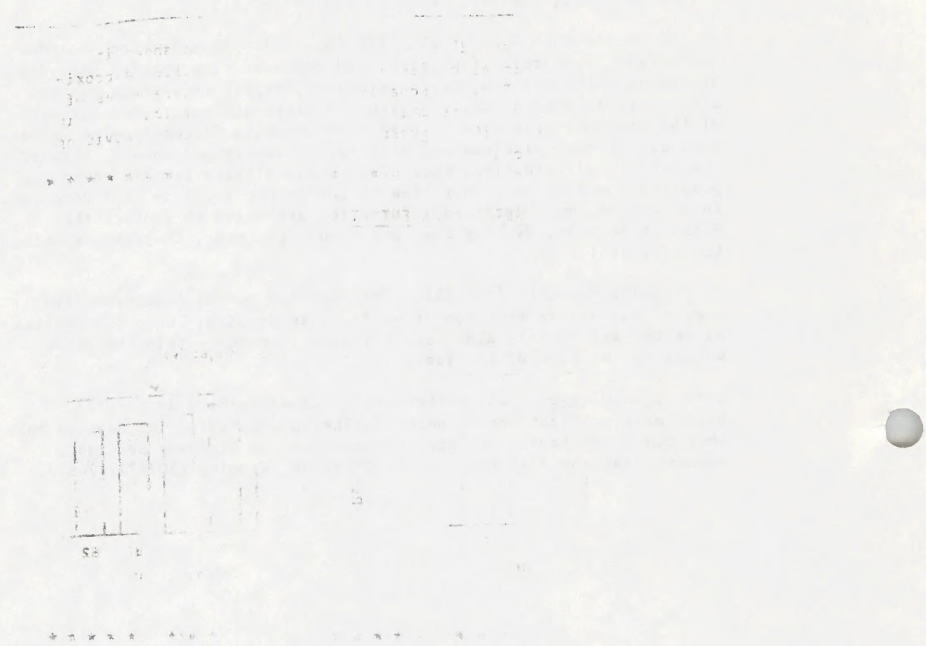

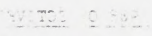


STATUS AND USE: There are 22 separate herds of bighorn sheep in Wyoming. During the winter of 1982-83 these herds totalled approximately 6,300 animals. They seasonally occupy 9,000 square miles of hatitat, of which 1,000 square miles are considered critical. During the 1982 hunting season, 193 bighorn sheep were harvested, providing 3,382 days of recreation.

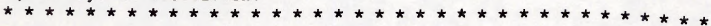

\section{PAST MANAGEMENT STATISTICS}
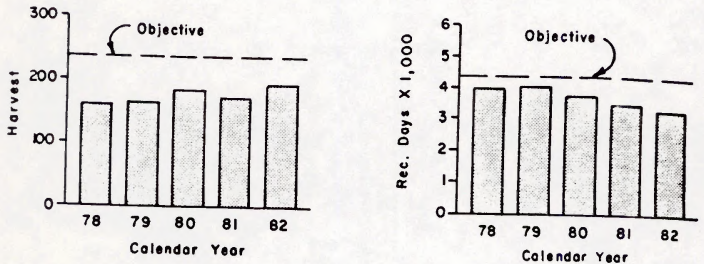

\section{OBJECTIVES}

1. To provide a harvest of 238 bighorn sheep.

2. To provide 4,334 sheep hunting recreation days.

3. To maintain a harvest success rate of .46 sheep per license holder.

4. To maintain a hunter effort rate of 18.2 days hunted per sheep harvested.

5. To maintain a wintering population of 7,180 sheep.

6. To maintain at least 9,000 square miles of occupied sheep habitat. 

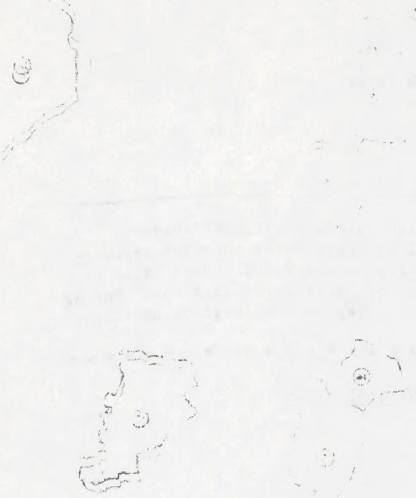

6

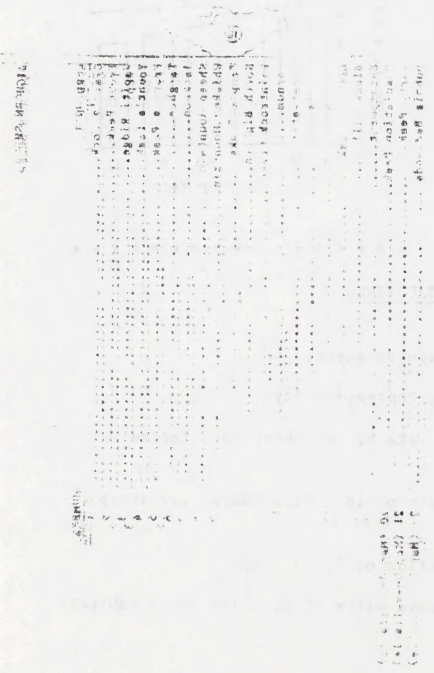




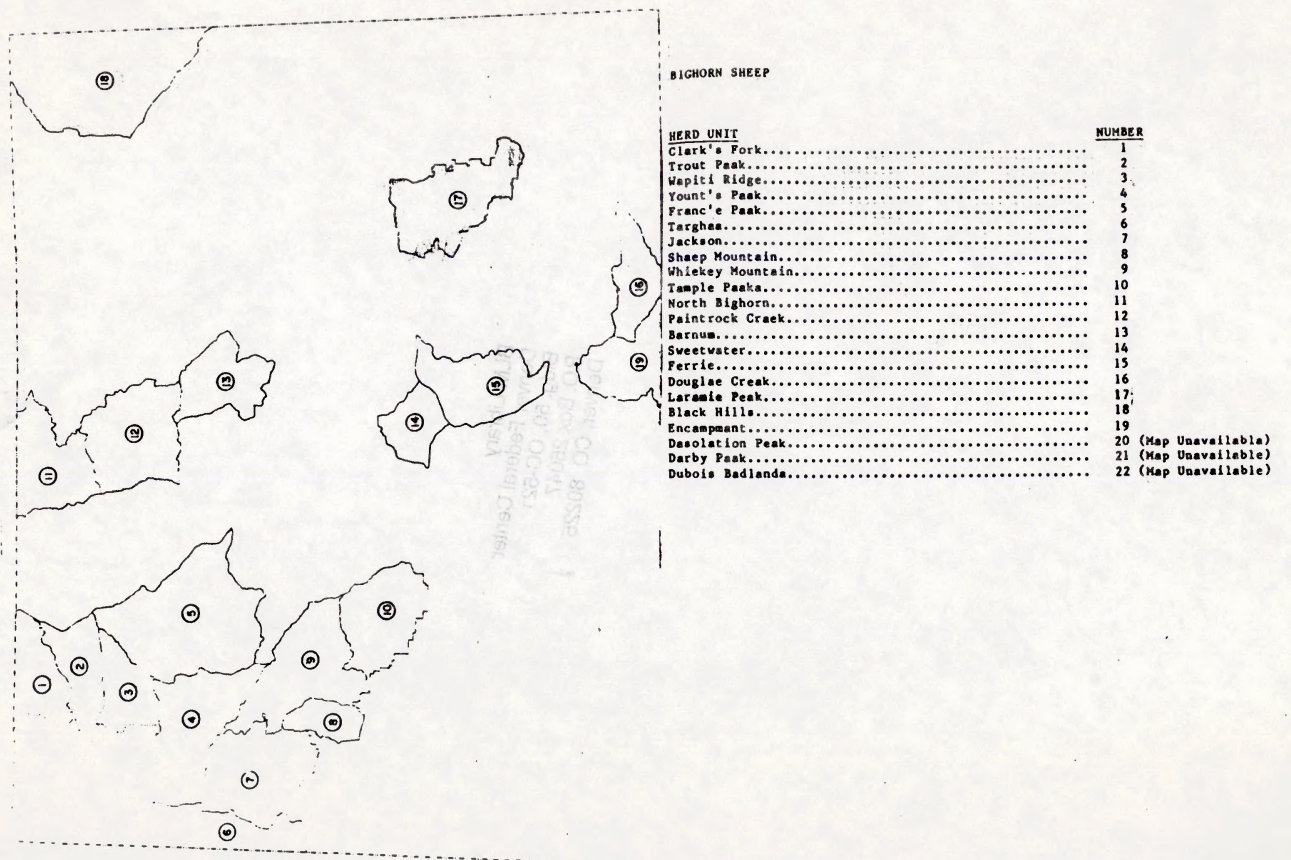




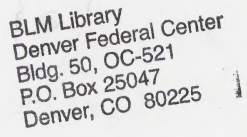

